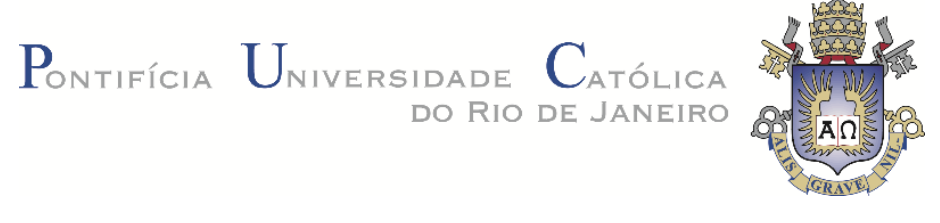

Marina Meira de Oliveira

\title{
Correção de Fluxo em uma Escola da Rede Pública Municipal do Rio de Janeiro: percepções e discricionariedade dos agentes implementadores
}

Dissertação de Mestrado

Dissertação apresentada ao Programa de PósGraduação em Educação da PUC-Rio como requisito parcial para obtenção do grau de Mestre em Educação.

Orientadora: Prof. Cynthia Paes de Carvalho 


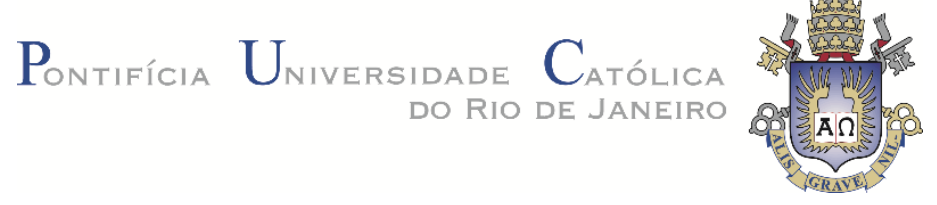

Marina Meira de Oliveira

Correção de Fluxo em uma Escola da Rede Pública

Municipal do Rio de Janeiro: percepções e discricionariedade dos agentes implementadores

\begin{abstract}
Dissertação apresentada como requisito parcial para obtenção do grau de Mestre pelo Programa de PósGraduação em Educação da PUC-Rio.
\end{abstract}

Prof ${ }^{a}$. Cynthia Paes de Carvalho

Orientadora

Departamento de Educação - PUC-Rio

Prof. Murillo Marschner Alves de Brito Departamento de Educação - PUC-Rio

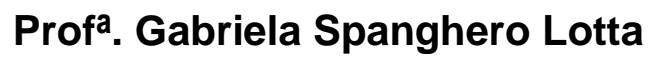
Universidade Federal do ABC

Profa. Monah Winograd Coordenadora Setorial do Centro de Teologia e Ciências Humanas

PUC-Rio

Rio de Janeiro, 06 de abril de 2017. 
Todos os direitos reservados. É proibida a reprodução total ou parcial do trabalho sem autorização da universidade, da autora e do orientador.

\section{Marina Meira de Oliveira}

Graduou-se como Bacharela em Letras: Português/Inglês pela Universidade Federal do Rio de Janeiro em 2013, e como Licenciada em Letras: Português/Inglês pela mesma universidade em 2014. Na PUC-Rio, integra o grupo de pesquisa Gestão e Qualidade da Educação (GESQ), coordenado pela professora Cynthia Paes de Carvalho. Interessa-se pelos temas de democratização da educação, políticas educacionais, gestão educacional e gestão escolar.

Ficha Catalográfica

Oliveira, Marina Meira de

Correção de fluxo em uma Escola da Rede Pública Municipal do Rio de Janeiro : percepções e discricionariedade dos agentes implementadores / Marina Meira de Oliveira ; orientadora: Cynthia Paes de Carvalho. - 2017.

199 f. : il. color. ; $30 \mathrm{~cm}$

Dissertação (mestrado)-Pontifícia Universidade Católica do Rio de Janeiro, Departamento de Educação, 2017.

Inclui bibliografia

1. Educação - Teses. 2. Política de correção de fluxo. 3. Aceleração da aprendizagem. 4. Discricionariedade. 5. Burocracia do nível na rua. I. Carvalho, Cynthia Paes de. II. Pontifícia Universidade Católica do Rio de Janeiro. Departamento de Educação. III. Título. 
Aos agentes da linha de frente do sistema educacional público que, apesar de todas as dificuldades, insistem na garantia do direito à educação. 


\section{Agradecimentos}

A Deus, pela força concedida ao longo deste período.

À minha orientadora Cynthia Paes de Carvalho, pela confiança depositada em mim desde os primeiros encontros, pela compreensão e carinho nos momentos mais difíceis, e pela competência com que me orientou e que me inspira.

Às Professoras Gabriela Lotta, Alicia Bonamino e Vanda Ribeiro, por aceitarem integrar a banca examinadora, e pelo tempo dedicado à leitura deste trabalho. Agradeço especialmente ao Professor Murillo Marschner Alves de Brito, presente desde a elaboração do Projeto de Pesquisa, pelas sugestões e contribuições valiosas, e por também compor minha banca.

Aos professores do Programa de Pós-Graduação em Educação da PUC-Rio, que me proporcionaram inúmeras experiências de aprendizado ao longo do Mestrado.

À CAPES, FAPERJ e PUC-Rio, pelos auxílios que permitiram a realização deste trabalho.

Aos amigos e companheiros de pesquisa do GESQ, por contribuírem para o meu desenvolvimento acadêmico e pessoal. Agradeço especialmente à Ana Luiza Honorato, pela parceria ao longo de toda a pesquisa, à Ana Cristina de Oliveira, pela disponibilidade e ajuda, e à Fátima Lima, pelas incontáveis contribuições, pelo auxílio em todos os momentos, e pela primorosa tese em que me inspirei.

Aos professores, diretoras, agentes educadoras e alunos que participaram desta pesquisa, pela generosidade em compartilhar suas experiências e percepções.

A Mariana, Stephany, Isabela e Luiza, por acompanharem de perto a realização deste trabalho. A meus pais, Alvaro e Joana, e meu irmão, Erick, por serem a base que me sustenta. Ao meu maior companheiro Diego, pela ajuda, amparo e afeto inestimáveis ao longo deste período, e também à sua família, que torceu por mim em todos os momentos. 


\section{Resumo}

Oliveira, Marina Meira de; Paes de Carvalho, Cynthia. Correção de Fluxo em uma Escola da Rede Pública Municipal do Rio de Janeiro: percepções e discricionariedade dos agentes implementadores. Rio de Janeiro, 2017. 199p. Dissertação de Mestrado - Departamento de Educação, Pontifícia Universidade Católica do Rio de Janeiro.

O presente trabalho busca compreender a implementação de uma política de correção de fluxo em uma escola municipal do Rio de Janeiro. Para isso, investigaram-se as percepções de agentes escolares sobre o projeto, analisando de que forma elas influenciam sua discricionariedade. Como referencial teórico, recorreu-se à sociologia da educação, particularmente às contribuições de Bourdieu sobre o fracasso escolar e o julgamento docente. Valeu-se ainda dos estudos sobre burocracia do nível da rua, inaugurados por Lipsky. Quanto à metodologia, analisaram-se os documentos relativos à política de correção de fluxo desenvolvida no Rio de Janeiro, com base na reconstrução realizada por Lima (2016). Em seguida, exploraram-se os dados do censo escolar relativos à escola selecionada. O material empírico foi gerado por meio de entrevistas semiestruturadas com 32 atores, incluindo professores, gestores, agentes educadores e alunos inseridos em turmas regulares e de aceleração. O estudo conclui que há resistência aos projetos, principalmente pela concentração de alunos considerados "problemáticos" em uma mesma turma. Predomina a percepção desses alunos como indisciplinados, desinteressados ou mesmo portadores de deficiências cognitivas, de modo que a responsabilidade por seu fracasso lhes é exclusivamente atribuída. Os agentes implementadores parecem orientar suas ações discricionárias com base em um senso prático-moral que distingue alunos "merecedores" dos "não merecedores", atendendo às suas necessidades percebidas de forma diferenciada. Por fim, discute-se em que medida a compreensão da aprendizagem escolar como um direito de todos pode ser ressignificada como uma recompensa a alguns, em um contexto de intensa sobrecarga de trabalho e falta de recursos.

\section{Palavras-chave}

Política de correção de fluxo; Aceleração da aprendizagem; Discricionariedade; Burocracia do nível da rua 


\section{Abstract}

Oliveira, Marina Meira de; Paes de Carvalho, Cynthia. (Advisor) Flow Correction in a Municipal School in Rio de Janeiro: implementing agents' perceptions and discretion. Rio de Janeiro, 2017. 199p. Dissertação de Mestrado - Departamento de Educação, Pontifícia Universidade Católica do Rio de Janeiro.

The present study aims to understand the implementation of a flow correction policy in a municipal school in Rio de Janeiro. To do so, we investigated teachers', principals' and students' perceptions on the project, analyzing how they influence their discretion. Among the theoretical references are the contributions of Sociology of Education, especially Bourdieu's ones concerning school failure and school agents' judgements, and the studies on street-level bureaucracy inaugurated by Lipsky. Regarding the methodology, we first analyzed the official documents related to the flow correction policy implemented in Rio de Janeiro, based on Lima's (2016) review on the subject. Secondly, we proceeded to an exploratory research into School Census data related to the selected school. The empirical material was generated through semistructured interviews with 32 subjects, including teachers, principals, assistants and students from regular and accelerated learning classes. The study concludes that there is considerable resistance to the flow correction policy, especially due to the concentration of those students identified as "problematic" in the same classes. There is a prevailing perception of overage students as undisciplined, uninterested, or even as cognitively impaired, holding such students accountable for their own failure. The implementing agents seem to guide their discretionary actions based on a practical-moral judgement that differs "worthy" students from "unworthy" ones, responding to their perceived needs differently. By way of conclusion, we discuss to what extent the understanding of school education as a public right can be resignified as a private reward in a context of work overload and scant resources.

\section{Keywords}

Flow correction policy; Accelerated learning; Discretion; Street-level bureaucracy 


\section{Sumário}

1. Introdução

2. Fracasso escolar e repetência: uma incursão pela Sociologia da Educação

2.1. Expansão do sistema escolar e manutenção das desigualdades educacionais

2.2. Fracasso escolar e sua construção social: a perspectiva bourdieusiana

2.3. A "Pedagogia da Repetência": mecanismos, causas e efeitos

3. Políticas de correção de fluxo e sua implementação: contribuições da Ciência Política

3.1. Desenvolvimento e implementação de mecanismos de correção de fluxo na década de 1990

3.2. A correção do fluxo escolar nos anos 2000: integração da equidade à qualidade

3.3. A implementação de políticas públicas com foco nos agentes: a burocracia do nível da rua e a organização educativa

4. O caso estudado: Correção de fluxo na Escola Sigma

4.1. A política de correção de fluxo implementada no município do Rio de Janeiro

4.2. O recorte de pesquisa: a Escola Sigma e a seleção dos entrevistados

4.3. A análise do material qualitativo: uma abordagem hermenêuticadialética

5. Percepções e discricionariedade: executando e fazendo a política no nível da escola 
5.1. Percepções sobre o público-alvo da política: os "alunos de projeto" 108

5.1.1. O "aluno de projeto" segundo os dados do Censo Escolar" 109

5.1.2. Percepções sobre o "aluno de projeto" na Escola Sigma 112

5.2. Percepções sobre a política: (re)significando e agindo sobre a proposta

5.3. Indícios de discricionariedade com base em dados do Censo Escolar: o encaminhamento de alunos para os projetos

6. A relevância do ethos: atendendo aos "merecedores" e "não merecedores"

6.1. Quem é ou não merecedor? A avaliação somativa do merecimento

6.2. Mais do que o pragmatismo: um "serviço extraordinário" para os merecedores 153

6.3. Pragmatismo: fazendo o que (percebe-se que) pode ser feito 158

6.4. Menos do que o pragmatismo: o mínimo possível para os não merecedores

7. Considerações Finais

8. Referências Bibliográficas 188

9. Apêndices 


\section{Lista de Figuras e Gráficos}

Gráfico 1: Evolução das taxas de distorção idade-série do Ensino Fundamental, Brasil (1982-2015)

Gráfico 2: Distribuição de alunos matriculados do $1^{\circ}$ ao $9^{\circ}$ ano na Escola Sigma em 2013 por sexo

Gráfico 3: Distribuição de alunos matriculados em turmas de Correção de fluxo na Escola Sigma em 2013 por sexo

Gráfico 4: Distribuição de alunos matriculados do $1^{\circ}$ ao $9^{\circ}$ ano na Escola Sigma em 2011 por raça/cor

Gráfico 5: Distribuição de alunos matriculados em turmas de Correção de fluxo na Escola Sigma em 2011 por raça/cor

Gráfico 6: Percentuais de matrículas em projetos de correção de fluxo na Escola Sigma, conforme níveis de defasagem (2010-2013)

Figura 1: Aliança PDE e Plano de Metas Todos pela Educação

Figura 2: A percepção de merecimento por parte dos agentes da Linha de frente 


\section{Lista de Quadros}

Quadro 1: Turmas de Projetos de Correção de Fluxo organizadas na Escola Sigma entre 2010 e 2016

Quadro 2: Sujeitos entrevistados na Escola Sigma em 2016

Quadro 3: Projetos de Realfabetização desenvolvidos na Escola Sigma entre 2010 e 2014 e indícios de discricionariedade no preenchimento do Censo Escolar

Quadro 4: Projetos de Aceleração desenvolvidos na Escola Sigma entre 2010 e 2012 e indícios de discricionariedade no preenchimento do Censo Escolar

Quadro 5: Projetos de Aceleração desenvolvidos na Escola Sigma entre 2013 e 2014 e indícios de discricionariedade no preenchimento do Censo Escolar 


\section{1 \\ Introdução}

As discussões a respeito de políticas de correção de fluxo se intensificam no cenário brasileiro a partir da frustração do potencial de equalização de oportunidades depositado na democratização do acesso à escolarização. Em épocas de ingresso restrito no sistema formal de ensino, acreditava-se que a ampliação desse sistema a toda a população seria a solução para as desigualdades de oportunidades educacionais. No entanto, mesmo após a ampliação do acesso à escola verificada ao longo da segunda metade do século passado, não foram constatadas mudanças significativas na estrutura de estratificação educacional do país (SILVA, 2003; FERNANDES, 2004; RIBEIRO, 2011). Os setores que anteriormente estavam fora do sistema educacional, tendo sido recentemente integrados a ele, eram os mesmos que passaram a enfrentar problemas de permanência com sucesso no sistema.

Dessa forma, os debates sobre a qualidade de ensino assumiram novas dimensões. Se, em um primeiro momento, o foco recaía sobre a oferta insuficiente de vagas, posteriormente ganharam destaque o congestionamento do fluxo escolar decorrente de múltiplas repetências, e o baixo aproveitamento dos estudantes aferido por meio de avaliações de larga escala (OLIVEIRA e ARAUJO, 2005). Quanto à primeira dimensão de qualidade centrada na oferta, é possível reconhecer a quase universalização do acesso ao Ensino Fundamental (OLIVEIRA, 2007) e a progressiva expansão do Ensino Médio e da Educação Infantil (SILVA, 2003). Por outro lado, ainda são graves os problemas sobre os

quais se centram as duas outras dimensões de qualidade apresentadas: o rendimento dos alunos no sistema e seu aprendizado efetivo. Cabe destacar que esses problemas são agravados pelas significativas desigualdades regionais do país.

Diante das elevadas taxas de repetência e da alta distorção idade-série dela resultante, políticas de não reprovação e de correção do fluxo escolar se intensificam no cenário nacional a partir dos anos 1990. Neste trabalho, 
destacamos as políticas de correção de fluxo, dirigidas aos alunos que apresentam uma distorção idade-série de dois anos ou mais, e comumente implementadas por meio de programas e projetos de aceleração da aprendizagem (ALVARSE e MAINARDES, 2010). Esses programas propõem a formação de turmas específicas para esses alunos em situação de atraso escolar, que são ensinados por meio de uma metodologia alternativa, com vistas à sua posterior reintegração em anos mais avançados do sistema regular. Para além da desobstrução do fluxo escolar, evitando a retenção de vagas no sistema, essas iniciativas buscam uma perspectiva de maior equidade no tratamento dos alunos em situação de maior vulnerabilidade. Dessa forma, buscam oferecer-lhes um tratamento diferenciado que garanta a regularização de sua trajetória, por meio da redução da distorção idade-série e da recuperação de seu atraso escolar.

Embora esses programas venham sendo implementados de forma permanente e capilarizada em diversos estados e municípios, a reprovação em massa e o consequente atraso escolar dos estudantes no país ainda merece destaque. Crahay e Baye (2013), ao analisar os resultados do PISA 2009 para a América Latina, tendo como referência os índices de repetência e o desempenho dos alunos em leitura e matemática, apontam que os níveis mais elevados de atraso escolar eram apresentados pelos alunos brasileiros. Nesse sentido, $40 \%$ dos alunos de 15 anos que participaram do PISA 2009 declararam haver repetido ao menos uma vez, ao passo que esse percentual era de $22 \%$ para o México, $23 \%$ para o Chile e $28 \%$ para o Peru. De acordo com os dados do Censo Escolar de 2015, a taxa média de distorção idade-série no Ensino Fundamental no país girava em torno de 19,2\%. Considerando o número total de matrículas nessa etapa de ensino no mesmo ano ${ }^{1}$, esse percentual indica que mais de 5 milhões de alunos apresentavam atraso escolar de dois anos ou mais no país.

A escolha de uma política de correção de fluxo como objeto da presente pesquisa orientou-se justamente pela relevância desses programas como esforços estratégicos para superar os desafios históricos do país que dizem respeito à oferta de um ensino de qualidade para todos. A iniciativa de debruçar-nos sobre a etapa de implementação propriamente dita encontrou eco em pesquisas anteriores que

\footnotetext{
${ }^{1}$ De acordo com o Censo Escolar de 2015, havia um total de 27.931.210 alunos matriculados no Ensino Fundamental no país.
} 
apontam que as intenções presentes na formulação desses programas não necessariamente correspondem à sua execução (PARENTE e LÜCK, 2004; BARBOSA, 2013; GRIS, 2015; ALMEIDA, 2015, entre outros). Dentre os principais achados dessas pesquisas, são apontados diversos fatores limitantes ao sucesso dos projetos, como insuficiência de recursos materiais e pedagógicos adequados para um processo diferenciado de ensino-aprendizagem, e a falta de apoio e monitoramento dos projetos por parte dos diferentes níveis de gestão. Para além desses problemas estruturais, os achados comumente apontam para dificuldades relacionadas à forma como os professores, gestores e demais membros da comunidade escolar percebem a proposta e, sobretudo, os alunos que constituem seu público-alvo.

Diante desses achados, o presente trabalho busca compreender a implementação de uma política de correção de fluxo em uma escola da rede pública municipal do Rio de Janeiro a partir das percepções dos agentes implementadores diretos no nível da escola. A eleição desses agentes como foco de análise se dá a partir dos estudos sobre burocracia do nível da rua, inaugurados por Michael Lipsky (1980) e aprofundados por diversos autores no âmbito da Ciência Política, que destacam o papel dos agentes da linha de frente do serviço público na execução de políticas. Nesse sentido, como apresentado por Lipsky (1980), compreendemos os burocratas do nível da rua como os agentes que lidam diretamente com os cidadãos a quem se destinam as políticas públicas no decorrer de seu trabalho, e que dispõem de uma margem significativa de discricionariedade na execução de suas atividades. A discricionariedade que esses agentes empregam para lidar com as contingências e limitações do contexto de implementação das políticas permite que eles influenciem a elegibilidade dos cidadãos no acesso aos benefícios ou às sanções previstas nos serviços públicos. Dessa forma, mais do que executores, esses agentes se tornam "fazedores de políticas".

Para além de sua importância como efetivos "criadores" de políticas, a escolha pelo foco de análise nos agentes implementadores se deu com base nas considerações de Lotta (2014). Após uma revisão acerca dos estudos sobre implementação de políticas públicas, a autora observa certa estagnação na importância dada a essa fase após o trabalho de Lipsky (1980), e sugere a incorporação de dois focos de atenção aos estudos no campo: o olhar sobre os agentes envolvidos no processo de implementação e o olhar para seus valores. 
Considerando que as ideias, as crenças e os valores desses agentes influenciam o exercício de sua discricionariedade (MAYNARD-MOODY e MUSHENO, 2003, MEIER e O'TOOLE, 2006, LOTTA, 2014), buscamos investigar suas percepções sobre a política em tela, os alunos que se constituem em seu público-alvo, e o contexto organizacional em que é implementada (a escola). A partir desse movimento, buscamos compreender de que forma essas percepções afetam as práticas concretas na execução da política. Considerando, ainda, que essas percepções e valores não são apenas expressões individuais, mas que se relacionam a fenômenos bastante explorados no campo da Sociologia da Educação que dizem respeito à construção do fracasso escolar, buscamos articulálos aos estudos nesse campo.

Cabe ressaltar que não encontramos nenhum trabalho a respeito da implementação de projetos de correção de fluxo e aceleração da aprendizagem na área de Educação que fizesse uso da literatura sobre a burocracia do nível da rua. Nesse sentido, buscamos contribuir para essa discussão ao lançar um olhar sobre a temática que faça uso de contribuições advindas do campo da Ciência Política, para melhor compreender as práticas discricionárias que caracterizam o processo de implementação da política em questão.

As principais perguntas às quais buscamos responder ao longo deste trabalho são, portanto: “Quais são as percepções dos agentes implementadores de uma política de correção de fluxo em uma escola da rede pública municipal do Rio de Janeiro a respeito da política e dos alunos que constituem seu públicoalvo?" e "De que forma essas percepções influenciam suas práticas discricionárias concretas, que caracterizam a implementação da política no nível da escola?"

A fim de compreender a política educacional em tela, analisamos os documentos relativos à política de correção de fluxo desenvolvida na rede pública municipal do Rio de Janeiro a partir de 2009, com base na ampla revisão e reconstrução da política empreendida por Maria de Fátima Magalhães de Lima $(2016)^{2}$. Em seguida, para compreendermos o contexto organizacional em que foi implementada, realizamos uma incursão exploratória sobre os dados do Censo Escolar relativos à escola selecionada. Por fim, para a análise das percepções dos

\footnotetext{
${ }^{2}$ A autora é integrante do grupo de pesquisa Gestão e Qualidade da Educação (GESQ), do qual também faço parte, o que facilitou um trabalho em conjunto para a realização desta pesquisa.
} 
agentes implementadores, realizamos entrevistas semiestruturadas com 32 indivíduos da comunidade escolar, dentre os quais incluem-se professores, diretores, agentes educadores e alunos inseridos em turmas regulares e em turmas de aceleração da aprendizagem.

Para melhor compreender o processo de análise pretendido nesta pesquisa, o presente trabalho está organizado em sete capítulos, incluindo esta introdução. No segundo capítulo, são trazidas algumas contribuições dos estudos em Sociologia da Educação, que ajudam a compreender de que forma a repetência e a distorção idade-série configuram-se como problemas graves no contexto brasileiro. Ainda neste capítulo, tratamos particularmente das contribuições do sociólogo Pierre Bourdieu para a compreensão da construção do fracasso escolar, comumente associado à repetência e à dificuldade de progressão no sistema de ensino. No terceiro capítulo, tratamos das políticas de correção de fluxo que se intensificam no cenário nacional a partir da década de 1990, com vistas à redução da distorção idade-série resultante de múltiplas repetências. Além disso, apresentamos brevemente alguns estudos sobre burocracia no nível da rua, aos quais articulamos um olhar sobre a escola enquanto organização educativa, a partir das contribuições de Licínio Lima (2011).

No quarto capítulo, iniciamos a análise do contexto institucional e organizacional em que a política em tela foi implementada. Em outras palavras, buscamos compreender o próprio desenho da política e seus objetivos, bem como a escola que selecionamos para o nosso estudo de caso. No quinto capítulo, analisamos as percepções dos agentes sobre os alunos com atraso escolar, que constituem o público-alvo da política em tela, e sobre a própria política em si. Já nesse capítulo, conseguimos perceber algumas práticas discricionárias adotadas pelos agentes com base nessas percepções.

No sexto capítulo, propomos a apresentação e a análise de determinadas ações discricionárias reconstruídas pelos agentes em suas entrevistas segundo uma classificação tripartida, com base em Maynard-Moody e Musheno (2003). Essas ações dizem respeito principalmente ao encaminhamento de alunos para os projetos de aceleração e à distribuição de recursos (materiais e humanos) a esses alunos no interior da escola. Finalmente, nas considerações finais, buscamos sistematizar os principais achados da pesquisa, apontar suas limitações, e promover uma reflexão a respeito do direito à educação em um contexto bastante 
desafiador, característico de grande parte das escolas das redes públicas de ensino do país. 


\section{2 \\ Fracasso escolar e repetência: uma incursão pela Sociologia da Educação}

Conforme anunciado, este capítulo busca compreender o fenômeno do fracasso escolar traduzido nos altos índices de repetência e na distorção idadesérie dela resultante, a partir de algumas contribuições da Sociologia da Educação. Para tanto, apresentamos inicialmente a revisão de alguns estudos que indicaram que, a despeito da expansão dos sistemas escolares, a estratificação educacional se manteve.

Em seguida, na seção 2.2 lançamos mão das contribuições de Pierre Bourdieu como forma de construção de sentido para os achados estatísticos apresentados na seção 2.1. Na perspectiva desse autor, o fracasso escolar é construído também no interior da escola, onde prevalecem relações de reprodução da condição social dos alunos recém-integrados ao sistema escolar.

Por fim, na seção 2.3, apresentamos alguns estudos que se debruçaram especificamente sobre o tema da repetência no Brasil e no mundo, tratando também de suas causas e efeitos.

\section{1.}

\section{Expansão do sistema escolar e manutenção das desigualdades educacionais}

A expansão dos sistemas escolares de forma a incorporar outros setores da população que não somente uma pequena elite socioeconômica é um fenômeno característico das sociedades consideradas modernas. A razão para a ampliação desse acesso à escolarização é objeto de disputa, sobre o qual se debruçam hipóteses explicativas que partem de perspectivas diversas em relação a sociedade, educação e desenvolvimento socioeconômico.

Uma das perspectivas mais amplamente difundidas ao longo do século XX que trata das relações entre desenvolvimento socioeconômico e educação foi 
aquela adotada pelos teóricos da Modernização (LENSKI, 1966; TREIMAN, 1970 entre outros), que encontravam inspiração nos trabalhos de Talcott Parsons (1959, 1970, 1974). Para este sociólogo, uma das principais características das sociedades modernas contemporâneas era a transição que se verificava de uma estratificação social hereditária, portanto, atribuída, para outra forma de estratificação social, não-atribuída. Em outras palavras, se a posição social dos indivíduos era anteriormente definida em consonância com seu pertencimento familiar, nas sociedades modernas os mecanismos de alocação de status passavam a se basear em características adquiridas, de acordo com esforços e competências individuais. É nesse sentido que o autor afirma:

A principal direção do desenvolvimento societário moderno encaminha-se para um padrão essencialmente novo de estratificação. Como já acentuamos, as bases históricas fundamentais da desigualdade legítima eram atributivas. A base de valor do novo igualitarismo exige, no entanto, uma base diferente de legitimação. Em termos gerais, essa base precisa ser funcional na sociedade concebida como um sistema. Portanto, os resultados diferentes do processo educacional competitivo devem ser legitimados através de interesse societário, nas contribuições de pessoas muito competentes; a competência é, pelo menos, uma função de grande capacidade inata e "boa instrução". (PARSONS, 1974, p. 145)

A demanda por outras formas de legitimação da estratificação social que não os mecanismos atributivos historicamente empregados deixa implícito que não se pretendia eliminar a estrutura de estratificação social, mas sim reorganizála segundo outra racionalidade. A difusão dos sistemas escolares conciliaria a busca por um valor de igualdade básica na disputa por status e os imperativos funcionais de uma sociedade cada vez mais dependente de conhecimento e eficiência coletiva para seu desenvolvimento. Nesse sentido, tinha-se em mente uma sociedade estratificada por competência, a qual seria revelada ao longo de uma "boa instrução", ou seja, ao longo de um processo de socialização de capacidades.

Para que essa nova lógica considerada meritocrática pudesse fazer jus à sua proposta de substituição de características herdadas por competência adquirida no processo de alocação de status, era preciso atender à premissa de equalização de oportunidades. Acreditava-se que esse processo, por sua vez, seria obtido com a expansão do sistema de ensino. Dentro dessa perspectiva, portanto, a principal crença dominante à época era de que "cada vez mais, existem oportunidades para que os relativamente desfavorecidos consigam vencer através da seleção, extraordinariamente regulamentada por normas universalistas" (ibidem, p. 119) 
No entanto, tem-se reiteradamente observado que a expansão dos sistemas escolares não garantiu uma redução significativa na associação entre origem socioeconômica e alcance educacional, conforme visionado pelos pressupostos liberais não-atributivos. Um grande marco dessa ruptura com visões otimistas de uma sociedade mais justa a ser alcançada por meio da ampliação do acesso à escolarização a todos foi a divulgação do Relatório Coleman em 1966. Realizado nos Estados Unidos, esse survey educacional apontava uma forte relação entre o desempenho escolar dos alunos e sua origem social, a qual parecia determinar seu alcance dentro do sistema.

O estudo, que reuniu informações de mais de meio milhão de estudantes, incorporando dados de suas características socioeconômicas, de seu desempenho e de suas escolas, havia sido encomendado pela Lei de Direitos Civis em 1964, que pressupunha a existência de grandes desigualdades entre as escolas americanas. À época, havia uma forte crença de que as diferenças de aprendizagem que vinham sendo observadas entre alunos mais e menos privilegiados deviam-se à desigualdade existente entre as escolas que frequentavam. Contudo, as conclusões do Relatório indicavam diferenças muito menores do que as esperadas entre as escolas, e, ainda, as consideravam responsáveis apenas "por uma pequena fração das diferenças no desempenho dos alunos" (COLEMAN, 1966, p. 131). Os achados apontavam as diferenças socioeconômicas entre os alunos como o fator de maior peso explicativo de suas desigualdades de desempenho. Com isso, colocava-se em xeque a crença modernista liberal no potencial que o sistema educacional teria para promover oportunidades iguais a indivíduos de origens socioeconômicas diferentes. A partir desse marco, a crença de que "a escola não faz diferença" (school makes no difference) tomou conta de grande parte do pensamento à época.

Muitas foram as outras pesquisas que também contribuíram para desafiar a relação causal entre desenvolvimento, expansão de sistemas escolares e equalização de oportunidades educacionais, a exemplo dos trabalhos de Mare (1980, 1981) e Shavit e Blossfeld (1993).

As pesquisas de Mare $(1980,1981)$ questionavam a relação causal entre expansão educacional e equalização de oportunidades ao apontar limitações nos métodos utilizados à época para estimar as desigualdades no sistema. Dentre seus principais achados, encontrou, nos Estados Unidos, um padrão de redução dos 
efeitos das barreiras sociais no alcance educacional operando das transições menos elevadas para aquelas mais elevadas, dentro de uma mesma coorte de idade. A conclusão a que chegava era de que o efeito das origens socioeconômicas se fazia mais forte nos níveis mais baixos da escolarização do que nos mais altos porque as populações que alcançavam esses últimos eram mais selecionadas. Essa diminuição no efeito da origem social de uma transição a outra poderia ser explicada, portanto, por uma diminuição progressiva na heterogeneidade das populações que realizavam as transições mais elevadas, "sobreviventes" de um processo bastante seletivo. Essa tendência de seleção diferencial proposta por Mare $(1980,1981)$ seguiria um padrão relativamente estável ao longo de sucessivas coortes, o que indicava que o desenvolvimento econômico não havia alterado significativamente os padrões de estratificação educacional.

Shavit e Blossfeld (1993), editores da obra Persistent Inequality. Changing Educational Attainment in Thirteen Countries, oferecem uma análise comparativa abrangente entre os sistemas de estratificação educacional de treze países diferentes ao longo do tempo. A principal questão apresentada é "Em que medida a relação entre as características socioeconômicas dos pais e as oportunidades educacionais foram alteradas ao longo do tempo, e por quê? "33 (SHAVIT e BLOSSFELD, 1993, p. 6). Para respondê-la, os autores trabalham com dados representativos das coortes nascidas entre 1910 e 1960 nos países analisados ${ }^{4}$.

No exame comparativo entre esses treze países, alguns padrões comuns são observados. Dentre eles, o mesmo que havia sido constatado por Mare (1980, 1981) quanto ao efeito decrescente da origem socioeconômica ao longo das sucessivas transições entre os níveis de escolaridade. Trata-se de uma tendência que não se modificou ao longo das coortes analisados, embora tenha sido constatado um aumento geral no alcance educacional da população, muito por conta da expansão das oportunidades educacionais nos primeiros níveis de ensino. À exceção da Suécia e dos Países Baixos, o resultado verificado para os outros onze países foi semelhante: a expansão educacional não conseguiu afetar

\footnotetext{
3 "To what extent has the relationship between parental socio-economic characteristics and educational opportunities changed over time and why?" (SHAVIT e BLOSSFELD, 1993, p. 6)

${ }^{4}$ Os treze países investigados foram Estados Unidos, a antiga República Federal da Alemanha, Inglaterra, País de Gales, Itália, Suíça, Países Baixos, Suécia, Japão, Taiwan, Polônia, Hungria e a antiga Tchecoslováquia.
} 
profundamente a relação entre origens sociais e alcance educacional, que se manteve relativamente estável ao longo do tempo.

No Brasil, onde a expansão educacional ocorreu tardiamente, os resultados verificados na estrutura de desigualdades não foram diferentes. A partir de um estudo histórico sobre a temática, Nunes (2000) aponta a distinção entre tipos de ensino - um para as elites e outro para as camadas populares - como um traço característico do sistema educacional brasileiro. Em seu trabalho, pode-se observar outra hipótese explicativa para a expansão do sistema escolar no país, diferente da perspectiva modernista mencionada acima. Para a autora, a ampliação da escolarização teria sido fruto de lutas por parte das camadas populares, com vistas a melhores oportunidades de ascensão social. A expansão não teria sido, portanto, uma iniciativa governamental de promover um "igualitarismo básico" no processo de alocação de status. Nesse sentido, aproxima-se de uma perspectiva neoweberiana (KARABEL e HALSEY, 1977), segundo a qual a expansão do sistema educacional refletiria mais a competição por status entre grupos sociais, do que as necessidades técnicas de uma economia em transformação.

Segundo Collins (1971), um dos teóricos associados a essa perspectiva, imperativos de ordem técnica não poderiam ser considerados a força motriz do processo de expansão, visto que sequer norteavam as principais atividades das escolas. Estas últimas seriam identificadas no "ensino de culturas de status específicas, tanto dentro quanto fora da sala de aula"5 (COLLINS, 1971, p.1010). Dessa forma, ainda que fossem bem-sucedidas ao transmitir conhecimento técnico, as escolas não tomariam esse propósito como sua principal função. Poderiam até mesmo falhar nesse quesito, desde que ensinassem "vocabulário e inflexão, estilos de vestimenta, gostos estéticos, valores e maneiras" (idem). Esses elementos culturais, definidos pelo grupo de status específico que estivesse no controle do sistema educacional, poderiam ser usados por eles para promover semelhante controle sobre o mercado de trabalho. Nesse sentido, o grupo dominante poderia facilitar o acesso para as posições mais altas àqueles que compartilhassem a cultura de elite. Da mesma forma, para posições de menor

\footnotetext{
5"The main activity of schools is to teach particular status cultures, both in and outside the classroom. In this light, any failure of schools to impart technical knowledge (although it may also be successful in this) is not important; schools primarily teach vocabulary and inflection, styles of dress, aesthetic tastes, values and manners." (COLLINS, 1971, p. 1010)
} 
prestígio, poderia selecionar aqueles que houvessem adquirido certo respeito por esses valores e estilos, ainda que não os dominassem.

Dentro dessa linha de raciocínio, diplomas e demais credenciais educacionais seriam fundamentais para atestar a posse dos conhecimentos valorizados e garantir as melhores posições de trabalho. Essas credenciais tornavam-se, então, objeto de disputa entre os grupos subordinados que lutariam pela ampliação de seu acesso e os grupos dominantes que se empenhariam em monopolizar suas posições de privilégio. Essa competição seria a força motriz do processo de expansão do sistema, acompanhado sempre de forças contrárias de contenção ${ }^{6}$.

É possível traçar paralelos entre essa perspectiva e o desenvolvimento histórico do sistema educacional brasileiro, segundo Nunes (2000). Como mostra a autora, a dualidade entre um tipo de ensino dedicado às elites - a socialização na cultura valorizada - e outro tipo de ensino às camadas menos privilegiadas - a apreciação e respeito por essa cultura - estava no cerne do sistema desde seu surgimento incipiente na época colonial. A mesma dualidade esteve marcadamente presente ao longo do Império, quando "a instrução primária pretendia cumprir um papel civilizador e a instrução secundária se destinaria a formar a elite ilustre e ilustrada" (NUNES, 2000, p.39).

Ao longo da República, principalmente na primeira metade do século XX, não houve alterações significativas nessa proposta de ensino dual. Na seção de sua obra dedicada à expansão do ensino secundário no Brasil, Schwartzman, Bomeny e Costa (2000) apontam de que forma o ensino secundário mantinha um entendimento restritivo, mesmo ao longo das Reformas de 1931 e 1942:

As linhas mestras do ensino secundário já haviam sido estabelecidas pela reforma Francisco Campos de 1931, que o havia definido como destinado à "formação do homem para todos os grandes setores da atividade nacional", construindo no seu espírito todo um "sistema de hábitos, atitudes e comportamentos". (SCHWARTZMAN, BOMENY e COSTA, 2000, p. 206 - grifos nossos)

Os grifos destacados sugerem mais uma aproximação com a perspectiva neoweberiana, no sentido de que caberia à escola o ensino de "culturas de status"

\footnotetext{
${ }^{6}$ Dentro dessa perspectiva, a expansão educacional não refletiria uma nova racionalidade no processo de obtenção de status e de seleção social. Pelo contrário, poderia até mesmo configurar um processo irracional, no qual as pessoas estariam em busca de cada vez mais qualificação para desempenhar funções que não necessitariam de tantas credenciais.
} 
a certos segmentos, que garantissem seu pertencimento ao estrato dominante e, consequentemente, as posições de trabalho mais elevadas. Esse monopólio das melhores posições por parte das camadas mais privilegiadas era garantido, à época, pelas próprias condições de acesso a esta etapa de ensino. Em 1939, dos 629 estabelecimentos nacionais de ensino secundário existentes, 530 eram particulares (SCHWARTZMAN, BOMENY e COSTA, 2000, p. 206). Outra barreira imposta era a necessidade de aprovação nos exames de admissão para o ensino secundário, que selecionavam mais ainda o público ingressante, e funcionavam como "uma espécie de senha para a ascensão social" (NUNES, 2000, p. 45). Conforme mencionado pela autora, diante da possibilidade de fracasso nos exames por conta de seu programa não divulgado e variável entre escolas, disseminavam-se cursos de admissão privados, dificultando mais ainda as chances de acesso das populações mais pobres.

Diante de tantos entraves, o acesso ao ensino secundário acabava praticamente reservado àqueles que tinham origens socioeconômicas mais privilegiadas. De fato, este era o ramo de ensino de maior prestígio, sendo o melhor caminho para o acesso ao ensino superior e para melhores empregos ${ }^{7}$. A Reforma Capanema (1942) manteve esse entendimento do ensino secundário como destinado à "preparação das individualidades condutoras, isto é, dos homens que deverão assumir as responsabilidades maiores dentro da sociedade e da nação" (SCHWARTZMAN, BOMENY e COSTA, 2000, p. 210). A dualidade de ensino assegurava, dessa forma, que o sistema educacional correspondesse à divisão econômico-social do trabalho.

Conforme exposto, mesmo durante as primeiras reformas educacionais na primeira metade do século XX, não houve uma real democratização do acesso à escolarização pós-primária. Assim, a completude do ensino secundário continuava representando um requisito significativo no acesso a melhores oportunidades de estudo e trabalho. Era justamente pelo que significava essa etapa de ensino que a demanda pelo seu acesso se intensificou entre as camadas médias e operárias da população urbana principalmente na segunda metade do século.

\footnotetext{
${ }^{7}$ As demais alternativas para aqueles que não passavam pelos exames de admissão - o ensino industrial, agrícola ou comercial - preparavam as massas para o trabalho. Como pontuado por Schwartzman, Bomeny e Costa (2000), eram ensinos de "segunda classe", sobre o qual havia poucas exigências até mesmo quanto à formação dos professores que neles lecionariam.
} 
Consequentemente, como pontua Nunes (2000, p. 48), “o ensino secundário foi forçado a expandir-se com o objetivo de conter as tensões sociais geradas por sua incipiente oferta". Diante desse cenário, uma progressiva expansão de vagas foi observada, principalmente a partir dos anos 1960, com a construção de escolas e aumento de matrículas nos estabelecimentos já existentes, e com a extinção do exame de admissão ao secundário em 1971.

No entanto, como constatado pela própria autora e por diversos outros pesquisadores (a exemplo de OLIVEIRA e ARAÚJO, 2005) a expansão do sistema educacional acabou por agravar as tensões sociais ao invés de contê-las, por não cumprir as expectativas que nele foram depositadas. A ampliação da oferta escolar veio acompanhada de notáveis dificuldades de progressão dentro do sistema, enfrentadas, sobretudo, por parte daqueles alunos que haviam sido recentemente integrados a ele. Essa situação podia ser observada por meio das múltiplas experiências de repetência que vivenciavam e, consequentemente, das altas distorções idade-série que passaram a apresentar. Lançando mão de documentos oficiais de 1998, Oliveira e Araújo (2005) mostram que, ao final da década de 1980, de cada 100 crianças que entravam na $1^{\text {a }}$ série, 48 eram reprovadas e 2 evadiam.

Desde então, diversos foram os estudos dedicados à análise da estratificação educacional no Brasil, e sua persistência mesmo com o movimento de expansão escolar. Silva (2003), por exemplo, demonstra que as desigualdades de chances de escolarização permaneceram presentes no país apesar da expansão, embora tenham sido deslocadas para níveis mais elevados de ensino. Fernandes (2004), também não constata tendências gerais de equalização de oportunidades no Brasil ao longo do tempo. Além disso, certas características adscritas como raça e origem urbana/rural parecem ter seus efeitos significativamente aumentados ao longo da expansão educacional que acompanhou o movimento de industrialização no país. Ribeiro (2011), ao analisar as chances de progressão educacional de indivíduos que teriam frequentado o sistema na época em que passou por reformas de ampliação, confirma a persistência das desigualdades ao longo do tempo. Além disso, encontra um efeito relevante da riqueza dos pais sobre as desigualdades de oportunidades educacionais em todas as transições. Aponta, ainda, a estratificação do sistema educacional brasileiro com base em tipos de escola com qualidades 
distintas (pública, pública federal e privada) como outro fator de peso na determinação das desigualdades de chances educacionais.

Em resumo, o que se buscou mostrar ao longo dessa revisão de alguns trabalhos nacionais e internacionais é que a expansão escolar não se traduziu em equalização de oportunidades. Em outras palavras, foi mantida a estratificação educacional, "a dependência do funcionamento do sistema escolar, enquanto responsável pela seleção social e socialização dos jovens, em relação à origem social dos alunos que por ele passam" (SILVA, 2003, p. 105). Particularmente no caso brasileiro, ainda permanecem problemas graves de repetência, evasão e fluxo escolar (NEVES, 2002).

Constatações desse tipo abriram espaço para que um forte pessimismo se instaurasse quanto à ineficácia da escola na superação do peso de fatores externos na progressão com sucesso dos alunos dentro do sistema. Mais do que isso, possibilitou a formulação de críticas mais severas à própria proposta do sistema escolar, que havia sido considerada pelos teóricos da modernização como um modo mais justo e meritocrático de seleção dos mais competentes, independentemente de sua origem social. Ao contrário do que previa essa hipótese, outras teorias atribuíram à escola um papel de conservação social, apontando a manutenção (e a legitimação) da exclusão que a expansão educacional representou para os grupos sociais menos favorecidos. Na próxima seção, buscamos tratar dessas outras teorias explicativas, comumente conhecidas como Reprodutivistas.

\section{2.}

\section{Fracasso escolar e sua construção social: a perspectiva bourdieusiana}

A perspectiva técnico-funcionalista da modernização atribuía à escola um papel de seleção social de indivíduos competentes. O processo que proporcionaria essa seleção era considerado justo e meritocrático, pois seria "extraordinariamente regulamentado por normas universalistas", (PARSONS, 1974, p. 119). Dessa forma, a expansão de seu acesso a todas as camadas sociais ofereceria oportunidades iguais para que todos pudessem demonstrar e aprimorar suas habilidades, e serem (ou não) selecionados de acordo com elas. 
Caso se acreditasse que o acesso ao sistema escolar igualava as oportunidades e que a diferenciação gerada em seu interior era mais justa do que outras fontes de desigualdade, seria possível concluir pela legitimação de seus resultados. Dessa forma, se um indivíduo tivesse um mau desempenho na escola, caberia a ele próprio a responsabilização por seu fracasso. Esse tipo de interpretação pouco crítica em relação à instituição escolar e ao que ocorria em seu interior abria espaço para a chamada "ideologia do dom". Em outras palavras, se as camadas recém-integradas ao sistema escolar apresentavam dificuldades de permanência com sucesso, talvez fosse porque não possuíam o mesmo "dom", ou "mérito" daqueles que já há um tempo vinham progredindo bem (SOARES, 2014).

Foi justamente na contramão desse tipo de pensamento que se desenvolveram as chamadas Teorias da Reprodução. Esses esforços teóricos contribuíram na construção de sentido para os achados dos grandes levantamentos estatísticos realizados principalmente a partir dos anos 1960, que atestavam a forte influência das origens sociais sobre o desempenho dos estudantes. Um dos teóricos Reprodutivistas mais conhecidos é o francês Pierre Bourdieu, para quem a instituição escolar não seria regulamenta por normas universalistas, mas sim particularistas. Para o autor, a escola teria como função latente a organização do "culto de uma cultura que pode ser proposta a todos, porque está reservada de fato aos membros das classes às quais ela pertence" (BOURDIEU, 2015, p.63). Em outras palavras, a escola selecionaria e sancionaria determinado arbitrário cultural, já transmitido hereditariamente para certos grupos, e o conferiria um aparente status de universalidade. Nesse sentido, a simples democratização do acesso em que se traduz a expansão escolar não ameaçaria os privilégios das classes dominantes, visto que manteriam suas vantagens em relação à cultura escolar por conta de sua familiaridade com ela. Pelo contrário, a inclusão de todos no sistema educacional poderia servir para atribuir um caráter de legitimidade à exclusão dos menos favorecidos.

Em seu texto "A escola conservadora", publicado originalmente em 1966, Bourdieu descrevia a situação de crise pela qual poderia passar um sistema educacional quando de sua expansão a outros segmentos que não aqueles já herdeiros da cultura valorizada em seu interior: 
De fato, o sistema de ensino pode acolher um número de educandos cada vez maior - como já ocorreu na primeira metade do século XX - sem ter que se transformar profundamente, desde que os recém-chegados sejam também portadores das aptidões socialmente adquiridas que a escola exige tradicionalmente. Ao contrário, ele está condenado a uma crise, percebida por exemplo como "queda de nível", quando recebe um número cada vez maior de educandos que não dominam mais, no mesmo grau que seus predecessores, a herança cultural de sua classe social [...] ou que, procedendo de classes sociais culturalmente desfavorecidas, são desprovidos de qualquer herança cultural. (BOURDIEU, 2015, p.64)

Conforme já mencionado, pode-se dizer que uma situação análoga ocorreu no caso brasileiro. Houve uma forte e recente expansão do sistema escolar a camadas populares que não compartilhavam as mesmas experiências culturais dos poucos que o frequentavam em um momento anterior, e que eram justamente aquelas exigidas pela instituição. Sob um olhar bourdieusiano, pode-se dizer que essa valorização de uma cultura particular por si só já contribuiria para a legitimação de desigualdades sociais. Isso ocorre porque a seleção por parte da instituição escolar dessas disposições culturais específicas as confere um status de superiores em relação às outras. Além disso, as colocam como universalmente válidas, mascarando a motivação social por trás de sua escolha - o fato de que pertencem aos setores mais privilegiados da sociedade. Com base nessa premissa, já se pode reconhecer uma vantagem inicial apresentada pelas camadas mais favorecidas em relação aos recém-incluídos.

Contudo, se o sistema escolar valorizasse apenas esses tipos de conteúdo que são mais familiares a alguns, seria ainda possível que - embora com mais esforço - ele conseguisse ensiná-los àqueles que não os dominam. Para tal, seria necessário o que Bourdieu chamou de "pedagogia racional e universal”, a qual recusaria uma igualdade puramente formal que despreza as diferenças dos educandos em relação ao domínio da cultura valorizada. Trata-se de uma pedagogia que "se obrigaria a tudo em favor de todos e se organizaria metodicamente em referência ao fim explícito de dar a todos os meios de adquirir aquilo que não é dado, sob a aparência do dom natural, senão às crianças das classes privilegiadas" (ibidem, p. 59). No entanto, Bourdieu sustenta que não se trata apenas de certos saberes serem valorizados pela instituição escolar, mas também o fato de que uma relação natural e familiar com eles é exaltada, talvez até mais do que o próprio saber em si. 
Essa familiaridade com a cultura e a linguagem só pode ser transmitida pela própria família, e de maneira quase que imperceptível, em oposição ao ensino formal, sistemático e intencional que é realizado na escola. A aparente naturalidade com que esses educandos herdam de suas famílias uma competência cultural, a facilidade linguística e um ethos (conjunto de atitudes e posturas a respeito da escola e de expectativas sociais) contribui para que seja percebida como uma espécie de dom, embora seja resultado de certa socialização. A valorização institucional dessa nova espécie de características herdadas pode ter consequências bastante significativas sobre o êxito escolar da criança, também na medida em que influencia o modo como os professores veem esses educandos.

Para Bourdieu, o "julgamento dos mestres" - que na maioria das vezes ocorre de forma inconsciente - incide não somente sobre a cultura aristocrática exigida, mas também sobre a relação do aluno com essa cultura. Assim, os professores estariam constantemente valorando se o aluno apresenta o bom gosto, o estilo e as aptidões que soam naturais para as classes mais cultivadas, ou se demonstram uma conduta demasiadamente escolar, que deixa transparecer o modo como a adquiriu. Essa apreciação, alimentada por um etnocentrismo de classe, poderia ser justificada pelo sentido que as classes cultas atribuem ao saber erudito e à função que incumbem à escola de transmiti-lo e, assim, perpetuá-lo.

Além disso, outras formas de apreciação do professor estariam em jogo. Para esse autor, muito do que se atribui à (falta de) vontade dos pais em relação ao prosseguimento dos estudos dos filhos e suas atitudes diante da escola corresponde, na realidade, à internalização das chances objetivas de futuro que julgam ter. As classes mais populares estariam cientes, ainda que implicitamente, da estratificação social e das baixas probabilidades de êxito e ascensão pela escola. Dessa forma, tenderiam a desejar o possível e não depositariam altas expectativas em relação a essa instituição, como já ocorre com as camadas médias. Essas atitudes dos pais baseadas em condições objetivas influenciariam, por sua vez, a postura das crianças diante da escola e do papel que ela desempenha em relação a seu futuro. Essas crianças, portanto, não herdariam o mesmo ethos de ascensão social das classes de transição. Diante desse cenário e muitas vezes partindo do pressuposto de que nem esses alunos, nem suas famílias “desejam muito da escola", não é raro que os mestres criem expectativas diversas sobre seus educandos. Os professores poderiam, ainda, vir a realizar uma espécie 
de prognóstico de fracasso em relação a alguns deles com base em suas origens socioeconômicas.

Aqui podem-se traçar algumas comparações com o contexto brasileiro, lembrando o alerta presente em Costa e Silva (2003) quanto aos riscos de uma fidelidade muito forte a teorias geradas internacionalmente. Segundo os autores, o deslocamento dos contextos a que se propuseram essas reflexões à nossa realidade local, que apresenta particularidades nem sempre correspondentes, pode criar empecilhos à compreensão de um fenômeno se feito sem o devido cuidado. Costa e Silva (2003) sugerem, então, que se busque um movimento constante de valorização de estruturas mais gerais, que podem ser transportadas sem o custo de um encaixe forçado, e de atenção às especificidades locais.

Nesse sentido, cabe relativizar os pressupostos bourdieusianos no que diz respeito às exigências que os professores fariam quanto a uma relação natural com a cultura erudita que os alunos deveriam apresentar. Já em 1967, o sociólogo Luiz Pereira mencionava a queda do prestígio ocupacional do magistério que se observava no Brasil. No contexto mais recente, verifica-se que não somente os alunos atendidos pelo sistema educacional público não são portadores de uma tradição de escolarização, bem como "boa parte do professorado também vem de famílias de pouca ou nenhuma inserção em ambientes letrados" (COSTA e SILVA, 2003, p. 117). Portanto, torna-se mais difícil concluir que haveria a mesma expectativa docente quanto a uma relação aristocrática do aluno com a cultura em um contexto no qual a maioria dos professores pertencem às camadas médias, muitos tendo vindo até mesmo das camadas populares. Aqui, poucos parecem ser os professores que apresentam, eles mesmos, essa naturalidade em relação aos saberes eruditos, cara às elites cultivadas.

Apesar da relativização quanto a esse primeiro tipo de julgamento baseado na relação com a cultura, podem-se encontrar semelhanças entre o segundo tipo de apreciação docente mencionado e o caso brasileiro. Em outras palavras, o julgamento em relação às condições socioculturais do alunado das classes populares e, sobretudo, certa condenação da ausência de um ethos de mobilidade social por parte dele pode se aplicar também à nossa realidade. Em seu livro "A escola numa área metropolitana", Luiz Pereira (1967) dedica um capítulo para a discussão das relações entre a escola e a área escolar. Nele, descreve de que forma as relações do pessoal docente-administrativo com os alunos e demais residentes 
da área se inscreviam numa hierarquia entre categorias socioeconômicas distintas. Considerando a si mesmos como pertencentes a uma "classe média", e a população da área escolar como de "classe baixa", os professores realizavam julgamentos a respeito daquela área e de seus moradores, nos quais se incluíam os alunos. O autor ressalta a representação negativa que o pessoal docenteadministrativo construía sobre o modo de vida daquela população:

Comparando seu estilo de vida, mais elevado, com diversos setores da vida dos moradores, aponta, em ordem de frequência decrescente, "deficiências" na alimentação, no vestuário, nos "bons modos", no comportamento cívico, na linguagem, nas diversões, na saúde, na higiene, nas leituras, no comportamento religioso e moral. Embora atribua em parte essas "deficiências" das famílias aos baixos salários percebidos pelos seus membros, o pessoal docente-administrativo tende a enfatizar outros fatores, julgando as "deficiências" no terreno das responsabilidades morais. Assim, o próprio estado financeiro desfavorável das famílias é imputado por muitos professores à "falta de vontade de trabalhar", à "falta de dedicação ao trabalho", à "falta de vontade de melhorar a vida". [...] Bastaria cotejar tais avaliações com as reais condições de vida da área escolar, descritas em capítulo precedente, para concluir-se pela existência de um estereótipo negativo de classe, entre o pessoal docente-administrativo. (PEREIRA, 1967, p.111-112)

Percebe-se, a partir do trecho, que também procediam no nosso contexto julgamentos valorativos sobre os alunos calcados em questões de caráter sociocultural, principalmente relativas à posse de um ethos de ascensão social. Afinal, embora se verifique uma maior aproximação entre a origem social de alunos e professores no caso brasileiro, esses últimos teriam, pelo menos, acessado e concluído o ensino superior. Dessa forma, pode-se dizer que teriam vivenciado certa ascensão social, possivelmente fruto de uma aspiração ao êxito pela escola relativamente maior. Com isso, pode-se compreender por que seus julgamentos tenderiam a enfatizar "as deficiências no terreno das responsabilidades morais" e uma "falta de vontade de melhorar a vida", uma vez que suas próprias histórias serviriam de exemplo de que é possível ascender por meio do esforço escolar.

Um outro ponto pode ser destacado no que diz respeito a comparações entre as noções de Bourdieu e o contexto nacional. Assim como em outras sociedades, a problemática envolvendo as atitudes das classes menos favorecidas em relação à escola e as chances de progresso que vislumbram através dela também podem ser acrescidas do fator raça. De acordo com Pinto (1987), tendo consciência das dificuldades escolares e profissionais que seus filhos podem encarar, famílias 
negras muitas vezes desencorajariam neles ambições elevadas. A falta de estímulo poderia estar relacionada tanto a uma avaliação das condições objetivas que apresentam, quanto a uma assimilação pessoal da representação negativa que se impõe socialmente sobre a população negra. De fato, no contexto brasileiro, os meninos negros constituem o grupo mais vulnerável ao fracasso escolar compreendido como repetência (ORTIGÃO e AGUIAR, 2013).

A partir desses pontos, algumas possibilidades foram levantadas respeito das percepções que se encontrariam em campo, no caso da presente pesquisa. Primeiramente, cogitou-se a possibilidade de que professores e diretores apresentassem percepções relativas aos alunos e suas famílias que dialogassem com os pressupostos bourdieusianos de "julgamento dos mestres". No caso de alunos que vivenciaram experiências de fracasso escolar e que foram enturmados nas turmas de correção de fluxo, esperou-se encontrar críticas quanto a uma "falta de vontade" de estudar ou trabalhar, que de alguma forma justificasse sua condição, bem como uma falta de participação de suas famílias. Em outras palavras, certa condenação quanto à ausência de um ethos de ascensão social por meio do esforço escolar estaria, a princípio, presente nos discursos dos agentes escolares, podendo ser usado como forma de responsabilização do próprio aluno quanto ao seu fracasso.

No caso das percepções dos estudantes com um histórico de repetências, baixas expectativas em relação à escola eram esperadas. Essa atitude em relação à escola e ao papel que ela poderia desempenhar em seu futuro também dialogaria com as noções bourdieusianas de internalização das chances objetivas de sucesso pela via escolar. Essa postura poderia, ainda, ser influenciada pelos "julgamentos dos mestres" de alguma maneira, no sentido de que estereótipos construídos por esses agentes pudessem contribuir para uma espécie de prognóstico de fracasso desses estudantes, que viesse a se refletir em suas trajetórias acidentadas.

Outro tipo de percepção em relação a esses estudantes passou a ser esperada, a partir das considerações de Bourdieu. Como mostra o autor, seriam dois os principais fatores que competiriam para as desigualdades de desempenho a escolar: a herança (ou não) de determinado capital cultural (facilidade verbal, conhecimento de obras de arte e informações sobre o mundo escolar) e de um ethos de ascensão social pela escola. Dessa forma, as principais protagonistas do fracasso escolar seriam "as crianças populares que não empregam na atividade 
escolar nem a boa vontade cultural das crianças das classes médias nem o capital cultural trazido das classes superiores" (BOURDIEU, 2015, p. 64). Essas, por sua vez, se refugiariam "numa espécie de atitude negativa, que desconcerta os educadores e se exprime em formas de desordem até então desconhecidas" (ibidem, p. 65). Desse modo, aventamos a possibilidade de que os alunos multirrepetentes fossem considerados pelos agentes escolares como aqueles mais indisciplinados. Em outras palavras, seu mau comportamento poderia refletir a atitude negativa que desenvolveram em relação à escola, manifesta em diferentes "formas de desordem".

O principal objetivo da presente seção foi mostrar a contribuição da perspectiva bourdieusiana para que se passasse das constatações das desigualdades escolares para a compreensão dos mecanismos por meio dos quais elas são promovidas. Nesse sentido, o sucesso escolar - "os benefícios que as crianças das diferentes classes e frações de classe podem obter no mercado escolar" (BOURDIEU, 2015, p. 81) - bem como seu oposto (o fracasso) não seriam efeitos das "aptidões naturais" dos indivíduos. O principal elemento explicativo das desigualdades de desempenho escolar estaria no capital cultural transmitido pelas diferentes famílias, bem como na posse ou ausência de um ethos de ascensão social por meio do esforço escolar.

À escola caberia o papel de reproduzir a ordem social por meio da valorização dessa cultura específica dos estratos dominantes, ao sancioná-la como universal e, então, exigi-la em suas atividades e avaliações. Considerando as vantagens que a familiaridade prévia com a cultura escolar concedia para uns e não para outros, podia-se compreender por que razão a desigualdade social mais ampla se refletia nos diferentes resultados acadêmicos. Dessa forma, em sua função socializadora, a escola "treina as crianças das origens sociais distintas para absorverem valores distintos e, em particular, treina as crianças das classes trabalhadoras em valores compatíveis com sua posição de classe subordinada" (SILVA, 2003, p. 119)

A próxima seção se dedica a analisar mais detalhadamente os altos índices de repetência que traduzem o fenômeno do fracasso escolar no Brasil. Tais discussões serão relacionadas, no capítulo seguinte, aos programas de correção de fluxo que vêm sendo desenvolvidos a partir da década de 1990 com vistas a tratar essa questão. Como será visto adiante, essas políticas são baseadas em uma 
espécie de discriminação positiva, com o intuito de oferecer um tratamento diferenciado aos alunos que vivenciaram múltiplas repetências. Nesse sentido, cabe a seguinte reflexão: se "a equidade formal à qual obedece todo o sistema escolar é injusta de fato" (BOURDIEU, 2015, p.59), pois sanciona as desigualdades iniciais entre os educandos, seriam as iniciativas de tratamento diferenciado capazes de proporcionar maior democratização de suas oportunidades educacionais?

\section{3.}

\section{A "pedagogia da repetência": mecanismos, causas e efeitos}

Durante muito tempo, as altas taxas de repetência no Brasil foram subestimadas em relação às taxas de evasão, que eram apontadas pelos dados oficiais como o principal problema de fluxo escolar no país. Em um denso estudo sobre evasão e repetência no país, Brandão, Baeta e Rocha (1985) pontuaram as dificuldades existentes no trabalho com as estatísticas relativas a esses fenômenos. As autoras mencionam a falta de confiabilidade nos dados oficiais, visto que não raramente as agências que os forneciam tinham formas de agrupamento diferentes (por domicílio, por unidades escolares, por regiões administrativas etc.). Além disso, as pesquisadoras relatavam dificuldades na análise de séries históricas de fluxo escolar, na obtenção de dados para todas as séries nos diferentes estados, na operacionalização informatizada dessas informações e na padronização de uma linguagem estatística para todo o país.

Diante dessas dificuldades, Costa Ribeiro e Fletcher (1989) apresentaram uma metodologia alternativa para tratar dos indicadores educacionais, que utilizava dados censitários de surveys como as PNADs (Pesquisa Nacional por Amostra de Domicílio), realizadas anualmente. Por meio da metodologia PROFLUXO, como foi denominada, passava a ser possível realizar inferências estatísticas sobre as taxas de promoção, repetência e evasão que não fossem influenciadas pelas declarações de alunos e agentes escolares. Isso era importante pois havia uma tendência à resposta negativa quando se perguntava a um aluno novo na escola se ele era repetente na série, por conta do estigma social que recai sobre a repetência. Assim, algumas crianças que constavam como novas em uma escola eram, na verdade, repetentes advindas de outras escolas. O mesmo viés 
aparecia, por vezes, na resposta de professores e diretores, devido ao conceito negativo que podia incidir sobre o próprio agente e a escola no caso de uma elevada taxa de repetência.

Além de problemas de natureza metodológica relativos à coleta de dados, também havia dificuldades relacionadas à própria contagem realizada pelos censos escolares. De acordo com Klein (2008), um dos grandes problemas que os censos escolares anteriores a 1995 apresentavam era de natureza conceitual: eram considerados repetentes somente os alunos que frequentavam a mesma série por conta de reprovação por avaliação ou frequência. Aqueles que haviam sido afastados por abandono e que posteriormente retornavam ao sistema na mesma série entravam como alunos novos no censo escolar, e não como repetentes. Do mesmo modo, não eram contabilizados como tais os "repetentes aprovados", ou seja, aqueles que repetiam a mesma série por conta da ausência de escolas com séries superiores onde habitavam, apesar de terem sido aprovados. Subestimavase, dessa forma, a repetência, ao passo que se superestimava a evasão e se inflacionava a quantidade de alunos novos. $\mathrm{O}$ conceito correto de repetência seria, portanto, o de frequência repetida de uma mesma série no ano seguinte, independentemente do motivo: por abandono, por reprovação por avaliação/absenteísmo, ou até mesmo apesar da aprovação.

Trabalhando com esse entendimento, Costa Ribeiro (1991) mostra que o principal problema de fluxo escolar no país era a excessiva taxa de repetência, sobretudo nas séries iniciais, onde chegava a ultrapassar os 50\% nas regiões mais pobres. Essa situação, além de provocar um congestionamento na $1^{\text {a }}$ série e dificultar a entrada de novas crianças no sistema, acabava por gerar mais evasão, visto que muitas crianças abandonavam a escola após acumularem diversas reprovações. Diante dos dados que apresenta, o autor cunhou a expressão "Pedagogia da Repetência" para indicar a naturalização deste fenômeno na cultura pedagógica nacional. Para o autor, esse fenômeno constituiria o principal empecilho à universalização da educação fundamental no país.

Ao analisar a repetência na $1^{\mathrm{a}}$ série - apontada como a mais grave - $\mathrm{o}$ autor mostra que, para as populações urbanas pobres do Nordeste, "a probabilidade de promoção para os alunos novos na la $^{\mathrm{a}}$ série é próxima de zero, sobe para aqueles que já têm uma repetência e só volta a cair para quem foi reprovado mais de duas vezes" (COSTA RIBEIRO, 1991, p. 15). Dados como esse sugerem uma prática, 
ainda que implícita, de reprovação sistemática de alunos novos, na qual "é imputado ao aluno um fracasso que já tinha sido definido a priori pela cultura do sistema educacional" (idem). Apesar de mencionar as perspectivas marxistas, reprodutivistas, ou de privação cultural como possíveis chaves de análise para a natureza do fenômeno, Costa Ribeiro afirma que nenhuma delas dá conta de sua ordem de grandeza, que se mostra alta em diversas camadas sociais. Cabe, portanto, uma reflexão sobre as razões que levam a esse fenômeno: seria ele um "componente cultural de nossa práxis pedagógica" ou "apenas uma consequência da ineficiência do sistema" (ibidem, p.16)?

Para o autor, as principais origens do processo estão no próprio desenvolvimento histórico do processo educacional brasileiro, ao qual faltou uma visão clara do modelo de escola que se buscou expandir. Com isso, o mesmo tipo de ensino dedicado às elites - na qual o professor atuava mais como um preceptor da educação orientada pela família do que mentor de um processo de ensinoaprendizagem autossuficiente - foi estendido a toda uma população que não compartilhava essa experiência. Segundo o autor, essa ausência de uma autêntica e autossuficiente função educadora da escola também estaria presente nos dias de hoje, nos quais a instituição assumiria outros papéis, como o de restaurante, creche, ou até mesmo "depósito de crianças". Com isso, passava a ser raro encontrar uma organização escolar que, de fato, se pretendesse a um processo formal de ensino-aprendizagem no seu interior, independentemente da situação do estudante. Fazendo um paralelo com a perspectiva bourdieusiana, pode-se dizer que era rara uma pedagogia que se organizasse metodicamente para oferecer a todos os alunos o que só era dado às crianças das classes privilegiadas, de forma aparentemente natural, pela família.

Aliás, cabe ressaltar que esse esvaziamento de sentido decorrente dos outros papéis que a escola passa a assumir pode gerar uma sensação de desresponsabilização quanto ao aprendizado dos alunos e um recurso à sua situação externa como justificativa por seu desempenho. Pode-se associar essa lógica às palavras do autor quanto ao fracasso escolar, comumente imputado "ora aos próprios alunos, ora a seus pais, ora ao sistema sociopolítico, raramente aos professores, sua formação ou à organização escolar" (ibidem, p. 17). Como mencionado na seção anterior, essa atribuição do desempenho dos alunos exclusivamente ao próprio aluno e/ou sua família constitui uma expectativa 
quanto ao tipo de percepção que podemos encontrar. Somamos a ela, a partir de então, a crença no esvaziamento da função educadora da escola, transformada em um “depósito de crianças”, como um possível elemento gerador dessa sensação de impotência e desresponsabilização.

Sem deixar de considerar a "pouca competência" e os baixos salários dos professores como elementos que competem para a ineficiência do sistema educacional, Costa Ribeiro (1991) oferece uma explicação primordialmente cultural ao fenômeno da repetência no país:

Parece que a prática da repetência está contida na pedagogia do sistema como um todo. É como se fizesse parte integral da pedagogia, aceita por todos os agentes do processo de forma natural. A persistência desta prática e da proporção desta taxa nos induz a pensar numa verdadeira metodologia pedagógica que subsiste no sistema, apesar de todos os esforços no sentido de universalizar a educação básica no Brasil. (COSTA RIBEIRO, 1991, p. 18)

Outra pesquisadora que, mais recentemente, também propôs uma compreensão de ordem cultural à repetência foi Maria de Lourdes Sá Earp. No artigo derivado de sua tese, Sá Earp (2009) apresenta as principais conclusões de um estudo que se dedicou à investigação da cultura da repetência em duas escolas cariocas, uma municipal e outra estadual, ao longo de dois anos. Por meio de entrevistas e observações, a autora pôde perceber estrutura que organizava e hierarquizava os alunos nas salas de aulas, à qual chamou "centro-periferia". Trata-se de um modelo que diz respeito aos padrões de interação que o professor estabelece com os alunos. Aqueles do "centro" (menos numerosos) têm suas perguntas mais frequente e prontamente respondidas, bem como são chamados individualmente mais vezes pelo professor. Os da "periferia" (mais numerosos), por sua vez, nem sempre são atendidos quanto intervêm em sala de aula, assim como são menos chamados pelos nomes, sendo mais comumente tratados como um grupo.

Os seus achados mostraram que os reprovados estavam justamente na "periferia" interacional da sala de aula, dentro de uma estrutura praticada como natural. Ao buscar possíveis explicações sobre essa dinâmica nas entrevistas realizadas com professores, a autora percebe que muitos não parecem crer que a escola tem a função de ser para todos, por isso tampouco seria a aula. Nesse sentido, o discurso de que muitos são os alunos que "não se interessam" e/ou "não têm vontade de aprender" ou até mesmo "não têm jeito" é recorrente, sendo 
muitas vezes tomado como a causa de seu fracasso. Nesse ponto, podemos mais uma vez remeter às contribuições de Bourdieu relativas ao julgamento dos mestres com base em um ethos, e o prognóstico de fracasso que esse julgamento pode trazer para determinados alunos. Outra conclusão importante à qual a autora chegou diz respeito à relação causal entre "estar no centro" e "ser bom aluno". Partindo incialmente da impressão de que os professores colocavam os melhores alunos no "centro", a autora afirma que sua pesquisa mostrou uma direção inversa: "os bons alunos são produzidos na própria estrutura da sala de aula. [...] A seleção que constrói os estudantes bons é produzida na escola e na sala de aula. O filtro é a reprovação" (SÁ EARP, 2009, p. 625).

Como conclusão, a autora aponta o "efeito Pigmalião" de Rosenthal e Jacobson (1968) como explicação para esse fenômeno. Em outras palavras, as expectativas docentes sobre os alunos ganham importância significativa, visto que elas orientariam suas escolhas relativas a quais estudantes colocar no "centro" e na "periferia" da estrutura, destinando a eles mais ou menos atenção e ensino. Em suma, Sá Earp (2009) compreende a reprovação menos como consequência da incapacidade dos professores de ensinar do que fruto de uma lógica segundo a qual os professores não ensinam a determinados alunos com base em princípios culturais. Trata-se, portanto, de uma tese que se assemelha à ideia proposta por Costa Ribeiro (1991) e a aprofunda, desvendando os mecanismos por meio dos quais a cultura da repetência ocorre. Seu estudo traz, ainda, a importância das expectativas docentes e sua relação com o desempenho dos alunos. A formação dessas expectativas constitui outro objeto bastante contemplado em diversas pesquisas.

O estudo de Barbosa e Randall (2004) busca analisar a formação das expectativas familiares e docentes em relação à trajetória escolar dos alunos, e suas relações com desigualdades sociais. As autoras examinam, ainda, a medida em que essas expectativas condizem ou não com o desempenho dos alunos em testes de matemática e linguagem, usado como variável de controle. Dessa forma, buscam aferir se, de fato, é o conhecimento efetivo de seu desempenho que norteia a formação de expectativas, ou se haveria algum tipo de viés implicado nesse processo. Ao passo que a pesquisa qualitativa de Sá Earp (2009) “não mostrou nenhum padrão, em termos de cor, gênero ou idade dos alunos" (SÁ 
EARP, 2009, p. 623), seu estudo apresenta alguns achados interessantes nesse sentido.

Para responder às suas questões, as pesquisadoras fazem uso de um survey aplicado a 24 escolas públicas de Belo Horizonte, no qual entrevistaram pais, professores e diretores de 602 alunos. Aos pais (sobretudo mães) perguntaram que nível de escolaridade acreditavam que seu/sua filho/filha tinha condições reais de atingir. Para os professores, perguntaram o nível de habilidade que cada um de seus alunos possuiria para enfrentar a vida escolar, em sua ótica. As expectativas das mães e das professoras são comparadas ao desempenho dos alunos, agrupados segundo gênero, etnia, renda familiar e escolaridade da mãe, elementos historicamente associados às desigualdades escolares.

Apesar de uma tendência geral das expectativas refletirem a diferença de notas nos testes, as autoras encontram resultados interessantes nessa análise por agrupamento. No caso das expectativas familiares, a cor do estudante e a situação socioeconômica de sua família (medida pela renda familiar e escolaridade da mãe) pareciam influenciar fortemente as expectativas maternas. Em outras palavras, a expectativa por parte das mães em relação ao destino escolar dos seus filhos era inferior se eles fossem não-brancos, se a renda familiar fosse mais baixa, e se a escolaridade da própria mãe fosse mais baixa, ainda que o desempenho das crianças nos testes pudesse sugerir uma situação um pouco melhor. Esses resultados apresentam relações com a teorização de Bourdieu (2015) discutida anteriormente quanto à reprodução das desigualdades sociais na vida escolar por meio da internalização das chances objetivas de sucesso por parte da família.

$\mathrm{Na}$ análise da percepção das professoras, a única variável que apresentou resultados significativos na explicação da variância da percepção docente é o sexo da criança, que não parecia afetar significativamente as expectativas familiares. As professoras claramente julgavam as meninas de forma mais positiva do que, a princípio, seu desempenho nos testes permitiria. Esse achado reflete os resultados de diversas outras pesquisas no sentido de que o processo de socialização de gênero acaba por tornas as meninas mais aptas à vida escolar, e os meninos mais preparados para a "rua" ou para os pátios da escola.

Essa influência do gênero na formação da avaliação docente também foi encontrada por Carvalho (2004), em seu artigo intitulado "Quem são os meninos que fracassam na escola?". Contudo, diferentemente dos achados de Barbosa e 
Randall (2004), a questão racial também se mostrou relevante neste estudo, realizado com alunos e professoras da $1^{\mathrm{a}}$ a $4^{\mathrm{a}}$ série de uma escola pública no município de São Paulo. O objetivo de Carvalho (2004) era compreender os processos que levavam um maior número de meninos em vez de meninas, e em sua maioria negros, a obterem notas ou conceitos mais baixos e a serem indicados para atividades de recuperação. Por meio de questionários e entrevistas, a autora buscou saber quem eram os/as alunos/as que haviam sido indicados para aulas de reforço, quem eram aqueles/as que causavam problemas de disciplina na percepção das professoras, e quem era elogiado por elas como bons/boas alunos/as.

Dentre seus principais achados, encontra-se uma influência bastante significativa do sexo da criança no julgamento professoral relativo tanto à questão da disciplina quanto ao desempenho escolar e indicação para atividades de reforço. Constituindo cerca de $50 \%$ da população, os meninos representavam $65 \%$ daqueles que estavam no reforço escolar e $71 \%$ do grupo considerado “indisciplinado". As meninas, por outro lado, tinham participação bem menor nas aulas de reforço e nos problemas disciplinares, sendo, ainda, mais elogiadas. O fator raça, ao passo que não apresenta influência significativa na avaliação dos professores quanto à indisciplina, se mostrou relevante no julgamento docente quanto à dificuldade de aprendizagem e encaminhamento para reforço. Enquanto $43 \%$ das crianças percebidas como negras tinham problemas de aprendizagem, essa proporção era de $28 \%$ no caso das crianças percebidas como brancas na mesma situação. Em suma, não somente havia uma predominância dos meninos entre os alunos indicados para as aulas de reforço, como também existia um protagonismo masculino claro entre os alunos "indisciplinados", ou seja, em ambos os problemas escolares.

Nesse sentido, a autora ressalta que nem sempre há uma clareza nos critérios adotados pelas professoras na indicação de alunos para o reforço escolar. Não raramente aspectos relacionados à aprendizagem se combinam com outros ligados à atitude e disciplina para concluir pelo encaminhamento dos estudantes para as atividades de reforço. Aliás, como apresentado pela autora, muitas professoras deixam claro que levam em conta em suas avaliações "tanto o desempenho propriamente dito, quanto o já mencionado 'compromisso do aluno' ou 'relação da criança com o cotidiano da escola"” (CARVALHO, 2004, p. 33). 
Os estudos apresentados neste tópico oportunizam uma reflexão sobre alguns mecanismos presentes no cotidiano escolar que podem contribuir para que o fracasso também seja construído em seu interior. Trata-se de evidências que sugerem atenção a dinâmicas e discursos específicos que podem ser encontrados em campo na presente pesquisa. Cumpre atentar, por exemplo, para as percepções e expectativas dos professores e diretores em relação aos alunos com dificuldade escolar, e para a possível influência de fatores como gênero, raça e ethos nesse processo. Além disso, cabe atentar para a possibilidade de que o encaminhamento dos alunos para as turmas de correção de fluxo envolva outros critérios que não somente aqueles explicitados pela política, da mesma forma que parecia ocorrer na indicação dos alunos para atividades de reforço no estudo de Carvalho (2004).

Por fim, cabe tratar brevemente dos efeitos esperados e comumente observados em relação à prática da repetência. Costa Ribeiro $(1991$; 1993) refuta a crença que subjaz à "pedagogia da repetência" quanto ao suposto benefício da repetição de uma série para a consolidação do aprendizado do aluno e sua consequente promoção no ano seguinte. Pelo contrário, fazendo referência aos cálculos estatísticos à época, o autor aponta a tendência à retroalimentação desse processo: "Observa-se que a probabilidade de um aluno repetente ser aprovado é quase a metade da probabilidade de aprovação de um aluno novo na série" (COSTA RIBEIRO, 1993, p. 72). Nesse sentido, a repetência acaba sendo uma das principais causas da própria repetência.

Crahay (2007), em sua revisão de literatura nos países francófonos sobre efeitos da repetência e tipos de pedagogia para alunos em dificuldade escolar, também afirma que a repetência é ineficaz. Um dos estudos ao qual o autor faz menção é o de Troncin (2005), que focaliza a evolução de alunos ao longo de dois anos. Para sua pesquisa, o autor pareia 103 duplas compostas por um aluno repetente e não-repetente, observando características comuns entre eles. Seus achados indicam que, embora os alunos repetentes apresentem algum progresso durante o ano em que repetem, a amplitude desse progresso é inferior àquela dos alunos de mesmo nível que foram promovidos. Além do quesito intensidade, a dimensão quantitativa também foi ressaltada: a progressão significativa dos alunos promovidos fracos ocorreu em 77 casos, ao passo que, para os repetentes, ocorreu em apenas 26. Por fim, as entrevistas realizadas com as crianças repetentes neste estudo confirmam as conclusões de Crahay (2003) quanto aos elementos 
socioafetivos envolvidos nesse processo. A repetição de um ano gerava um estigma nesses alunos, que acabava por agravar suas dificuldades de aprendizagem.

Correa (2013) também apresenta evidências nacionais que problematizam o efeito pedagógico da repetência para a consolidação dos conhecimentos por parte do aluno. Em sua dissertação de mestrado, o autor realiza um estudo observacional longitudinal e comparativo entre alunos repetentes e alunos promovidos, examinando o impacto da repetência nas medidas de proficiência em Português e Matemática desses alunos. Indo ao encontro do que outras pesquisas concluem, como as apresentadas acima, seus achados indicam uma progressão menor por parte dos alunos repetentes em relação aos promovidos ao longo de sua trajetória escolar.

Diante das constatações quanto ao efeito prejudicial da repetência em termos de retenção de vagas no sistema e da ausência de benefícios para a progressão dos alunos, reflexões acerca de medidas mais eficazes para o tratamento do fracasso escolar começaram a surgir. Debates a respeito de políticas que evitassem as reprovações e combatessem as altas taxas de distorção idadesérie se fazem presentes no cenário nacional desde o início do século passado, tendo sido pioneiramente experimentadas no final da década de 1950 (MAINARDES, 2007) e intensificadas nos anos 1990 (MAINARDES, 2006). No capítulo a seguir, passamos, portanto, à abordagem dessas políticas. 


\section{3 \\ Políticas de correção de fluxo e sua implementação: contribuições da Ciência Política}

Após a revisão de estudos que contribuem para a compreensão do problema do fracasso escolar e da repetência, passamos, neste capítulo, à análise de políticas que foram desenvolvidas para o tratamento da questão. Mais especificamente, focalizamos as políticas de correção de fluxo implementadas no país sobretudo a partir da década de 1990, em um contexto de Reforma do Estado. Essas políticas, desenvolvidas por meio de programas e projetos de aceleração da aprendizagem, têm como principal propósito a redução da distorção idade-série dos alunos e o descongestionamento do fluxo escolar.

Desde a seção 3.1, apresentamos estudos que sugerem que seus objetivos nem sempre foram atingidos, por conta de diversas dificuldades enfrentadas em seu processo de implementação. Na seção 3.2, tratamos da nova força que essas políticas ganharam nos anos 2000, sobretudo a partir da criação do Índice de Desenvolvimento da Educação Básica (IDEB) em 2007, que integra o fluxo e o desempenho escolar como medidas de qualidade. Nessa seção, novamente apresentamos estudos que sugerem que as ações dessas políticas nem sempre corresponderam às suas intenções.

Por fim, na seção 3.3, trazemos algumas contribuições da Ciência Política para que possamos melhor compreender o processo de implementação de políticas públicas. Os principais estudos revisados dizem respeito à burocracia no nível da rua, ou seja, às agências da linha de frente na implementação de políticas e na oferta dos serviços públicos. Propomos uma articulação entre os estudos da escola enquanto organização educativa, com base em Lima (2011), e os estudos sobre o trabalho no nível da rua. Dessa forma, buscamos compreender os atores escolares enquanto agentes implementadores diretos de políticas educacionais, que desfrutam de uma margem significativa de discricionariedade na condução de suas atividades diárias. 


\section{1. Desenvolvimento e implementação de mecanismos de correção de fluxo na década de 1990}

As iniciativas de ampliação do acesso à escolarização a um maior contingente populacional, promovidas principalmente a partir dos anos 1960 no país, fazem parte do que se pode chamar de um primeiro ciclo de reformas educacionais na América Latina (CASASSUS, 2001). Diante da constatação da baixa efetividade desse sistema que se expandiu, tendo em vista as elevadas taxas de repetência e distorção idade-série, outras políticas passaram a ser formuladas para o tratamento da questão.

Dentre elas, encontra-se a implantação de ciclos de formação ou aprendizagem na década de 1980. Desenvolvidos sobretudo nos anos iniciais de alfabetização, a organização em ciclos tem como principal objetivo permitir que cada estudante tenha seu ritmo diferente de progressão respeitado, não havendo interrupção da sua trajetória escolar (TURA; MARCONDES, 2011). Essa proposta, que não prevê a retenção de alunos em periodicidade anual como ocorre na organização seriada, configurou um importante mecanismo para a redução da reprovação que incidia maciçamente sobre a transição da $1^{\mathrm{a}}$ para a $2^{\mathrm{a}}$ série, e para a consequente melhoria do fluxo. Implantadas inicialmente em alguns estados da federação nos anos 1980 (São Paulo, Minas Gerais e Paraná), essa política adquiriu abrangência nacional nos anos seguintes (LIMA, 2016).

Outra política destinada à regularização do fluxo escolar também implantada na década de 1980 e expandida posteriormente foram as classes de aceleração da aprendizagem. A intensificação desses programas na década de 1990, destinados à recuperação do atraso escolar dos alunos defasados, esteve relacionada a um segundo ciclo de reformas educacionais na América Latina. Segundo Casassus (2001), essa nova geração é marcada por processos mais complexos, relacionados a mudanças na gestão dos sistemas educacionais e à preocupação com a melhoria da qualidade e equidade desse sistema.

Ainda de acordo com Casassus (2001), essas reformas educacionais empreendidas nos anos 90 foram orientadas a partir de três objetivos principais: 1) a focalização da educação dentro de uma perspectiva de desenvolvimento social e, sobretudo, econômico; 2) a adoção de um novo estilo de gestão no sistema educacional, que envolvia uma abertura à atuação de outros setores, e processos 
de descentralização; 3) a melhora dos níveis de qualidade de aprendizagem através de ações no nível micro e macro, dentre as quais estavam os programas compensatórios baseados em uma discriminação positiva.

Em relação ao primeiro objetivo, a centralidade que o tema da educação adquiriu no discurso político dos países latino-americanos relaciona-se à compreensão de que a escolarização poderia contribuir para a melhora de capital humano. Consequentemente, contribuiria para uma melhor inserção desses países na economia globalizada. O respaldo a esse discurso pôde ser verificado no âmbito financeiro, com destaque para o aumento do crédito internacional. No que respeita ao segundo objetivo, o autor insere as mudanças de gestão empreendidas no sistema educacional dentro de um contexto mais amplo de Reforma do Estado. Trata-se de uma redefinição do papel dessa instituição, que abriu espaço para a atuação de outros setores da sociedade civil no exercício de suas atribuições. $\mathrm{Na}$ esfera educacional, essa nova gestão mais "receptiva" esteve relacionada à possibilidade de participação de outros setores sociais na discussão e no compromisso com a educação pública, por meio de parcerias público-privadas, por exemplo. Previa-se, ainda, uma nova organização estatal para a prestação desse serviço, em que decisões estratégicas eram tomadas em nível central, e decisões mais operacionais podiam ser delegadas a esferas administrativas menores. Dessa forma, observou-se um processo de descentralização ${ }^{8}$ acompanhado de movimentos paralelos de centralização, visto que aspectos estratégicos se mantinham a nível central.

O terceiro objetivo, por sua vez, diz respeito à melhoria nos níveis de qualidade e equidade do sistema escolar. Para que se alcançasse esse propósito no nível micro, ou seja, no tocante à organização escolar e sua gestão, buscava-se implantar níveis de autonomia e um currículo adequado às especificidades das escolas. Já no nível macro, dois aspectos constituíram-se centrais, para além de uma reforma curricular: a introdução de sistemas de avaliação do desempenho e a implementação de programas compensatórios de discriminação positiva. Esses últimos constituem o foco de interesse do presente trabalho.

\footnotetext{
${ }^{8}$ É nesse sentido que, para Casassus (1990), essa descentralização proposta nos países da América Latina, com algumas exceções, se caracterizaria mais como uma desconcentração - compreendida como "processos cujo objetivo é assegurar a eficiência do poder central" - do que como uma descentralização propriamente dita - "um processo que visa assegurar o poder local" (p. 17)
} 
Como pontuado por Casassus (2001), o desenvolvimento desses programas na América Latina como um todo aponta novamente para o fato de que esforços de descentralização neste período estiveram acompanhados de uma certa "reserva" por parte do Estado central quanto à capacidade de intervenção nas escolas. Essas ações intervencionistas se justificariam com base na necessidade do Estado "velar pela equidade no sistema" (idem, p. 23). Neste caso, a preocupação com a equidade se traduzia na proposta de um tratamento diferenciado - daí a ideia de discriminação positiva - para alunos em situação de maior vulnerabilidade. Esses alunos seriam aqueles que apresentavam dois ou mais anos de atraso escolar, em decorrência de múltiplas repetências vivenciadas no sistema. A principal estratégia para "compensar" esse atraso era a formação de classes de aceleração para esses alunos, com vistas à sua posterior reinserção em turmas regulares e regularização de seu fluxo de escolarização. Essas políticas estariam, portanto, calcadas em um objetivo duplo: a busca por um efeito pedagógico de recuperação do atraso escolar discente, e por um efeito de descongestionamento do fluxo, represado por conta de contínuas repetências.

A breve menção ao contexto da Reforma do Aparelho do Estado, baseada em preceitos como eficiência, racionalização de recursos e avaliação de resultados, ajuda a compreender a intensificação dos programas de correção de fluxo em meados da década de 1990. Para além disso, cabe destacar que a formação das classes de aceleração como forma de corrigir o fluxo escolar também foi facilitada pela flexibilidade consagrada na nova Lei de Diretrizes e Bases da Educação Nacional. A nova LDB explicitava a possibilidade de organização da educação básica em séries, períodos, ciclos, grupos não seriados "sempre que o interesse do processo de aprendizagem assim o recomendar" (BRASIL, 1996, art.23).

Ainda que esteja fora do escopo deste trabalho se aprofundar nesse período de reformas, é importante mencionar as controvérsias que giram em torno das políticas educacionais promovidas ao longo dos anos 1990, incluindo a política em tela. Dentre elas, encontra-se a crítica relativa a uma compreensão utilitária de termos como equidade e ao pressuposto da superioridade do setor privado em relação ao público para a prestação dos serviços educacionais. Para muitos autores a exemplo de Cruz (2003) e Gentili (1996), os preceitos que norteavam essas reformas seguiam uma lógica neoliberal de mercado que, ao ser transposta para a 
educação, buscava fomentar a concorrência e a competitividade por recursos como forma de assegurar a eficiência e a qualidade dos serviços educacionais prestados. Dessa forma, o Estado poderia reduzir sua participação financeira na prestação desses serviços, racionalizando e economizando insumos. Para além disso, a equidade estaria sendo tratada de forma compensatória e redistributiva, ao invés de ser alcançada por meio de investimentos em políticas de distribuição de recursos para todos. Nesse sentido, apenas os setores em situação de maior desvantagem seriam focalizados pelas políticas desenvolvidas, que buscavam reparar e compensar sua situação de vulnerabilidade.

Esse entendimento de que as políticas educacionais desenvolvidas ao longo dos anos 1990 foram determinadas por uma agenda internacional ditada por organizações multilaterais é bastante recorrente na literatura educacional brasileira. No entanto, concordando com Oliveira (2007), é importante atentar para o risco de aprisionamento que essa concepção pode oferecer quando levada a um extremo. Nessa perspectiva, as ações desenvolvidas no terreno educacional (e seus efeitos) passam a ser compreendidos apenas como reflexos desses interesses dominantes. Dessa forma, todas as motivações por trás das reformas são interpretadas unicamente como expressão de um pensamento neoliberal e de interesses econômicos. Além disso, não são levadas em consideração as contradições e os conflitos inerentes à burocracia educacional em cada contexto de implementação, que dificultam a adoção fiel e homogênea de uma cartilha. Em outras palavras, apesar de reconhecer a forte influência desses organismos internacionais e das concepções neoliberais de gestão estatal em todo esse debate, cumpre atentar para não reduzir as políticas desenvolvidas a um mero reflexo do que propunha essa "receita".

É nesse sentido que Sampaio (2000), tratando das classes de aceleração como uma intervenção pedagógica, chama atenção para o fato de que esses programas não poderiam ser reduzidos apenas a uma questão econômica de racionalização de recursos e descongestionamento do fluxo escolar. Pelo contrário, havia um problema educacional que buscavam tratar: o atraso escolar resultante de reprovações contínuas e naturalizadas, que geravam uma baixa autoestima, bem como maiores chances de evasão e abandono. Esse fracasso de longa data no cenário nacional, produzido tanto por fatores externos, quanto internos à própria escola, exigia um enfrentamento também pedagógico. Partindo 
dessa compreensão, a autora concebe a intervenção proposta como "uma das providências a ser articuladas a muitas outras" (p.61) no combate ao fracasso escolar, que incide principalmente sobre os alunos já marcados pela seletividade e discriminação:

As classes de aceleração podem ser entendidas como rota alternativa e provisória para pôr em marcha as possibilidades desses alunos, alavancar seu processo de aprendizagem e permitir sua reinserção no percurso regular. Em algum ponto eles tropeçaram e têm o direito de retomar seu caminho, tendo acesso aos instrumentos de compreensão de mundo, ao convívio com seus pares de idade, beneficiando-se realmente do trabalho formador de seus educadores. É preciso enfrentar $o$ fato de que na escola esse trabalho emperra diante de muitos obstáculos, entre os quais a presença forte de preconceitos e mecanismos de seletividade e exclusão, que levam a rotular os alunos multirrepetentes de incapazes, imaturos, incompetentes, deficientes, sem que se consiga reverter sua situação, fruto de problemas que se originam na organização social e na própria escola. (SAMPAIO, 2000, p. 61-62)

Dessa forma, os programas de aceleração da aprendizagem previam a organização de turmas especiais para alunos com defasagem idade-série igual ou superior a dois anos, de modo que fossem ensinados por meio de uma pedagogia alternativa àquela das turmas regulares, mas que os tornasse aptos a reingressarem e progredirem nessas turmas. O principal objetivo da política de correção de fluxo assim configurada à época era, portanto, a correção da distorção e do fluxo aliada a uma "mudança de atitude comportamental" em relação aos alunos com atraso escolar, que colaborasse para a "quebra da cultura da repetência" (PRADO, 2000, p. 53). Dentre os efeitos esperados a partir da correção estava, ainda, a melhora na qualidade do ensino fundamental e o aumento das chances de terminalidade dessa etapa, de forma que o aluno pudesse prosseguir seus estudos em nível médio. Percebe-se no formato dessa política uma proposta de tratamento diferenciado, e não de uma equidade formal que, como pontuado por Bourdieu anteriormente, seria considerada "injusta de fato".

Implementadas a partir de 1995 inicialmente em determinados estados e municípios nas quatro primeiras séries do Ensino Fundamental, as políticas de correção de fluxo escolar se expandiram nacionalmente. Segundo o mapeamento realizador por Parente e Lück (2004, 2007), um indicativo dessa expansão em nível nacional foi a criação do Programa de Aceleração da Aprendizagem pelo MEC, em 1997. Esse programa foi implementado em parceria com o Instituto Ayrton Senna (IAS), a Petrobrás e o Banco Nacional para o Desenvolvimento 
Econômico e Social (BNDES), contando também com o apoio técnico oferecido por organizações não-governamentais ${ }^{9}$. Para além do suporte financeiro do Grupo Banco Mundial, o próprio MEC previa o direcionamento de recursos para os estados e municípios que aderissem voluntariamente ao programa. Esses deviam ser investidos em capacitação de professores e produção/distribuição de materiais didáticos produzidos pela instituição parceira.

No que diz respeito aos resultados alcançados quanto à desobstrução e regularização do fluxo escolar, observou-se uma queda expressiva nas taxas de distorção idade-série entre as décadas de 1980 e 1990, indicando uma contribuição positiva dessas políticas ${ }^{10}$ (SILVA, 2003; OLIVEIRA e ARAUJO, 2005). O gráfico abaixo contribui para uma melhor elucidação das quedas nas taxas de distorção idade-série observadas a partir da década de 1980:

\section{Gráfico 1: Evolução das taxas de distorção idade-série no Ensino Fundamental, Brasil (1982-2015)}

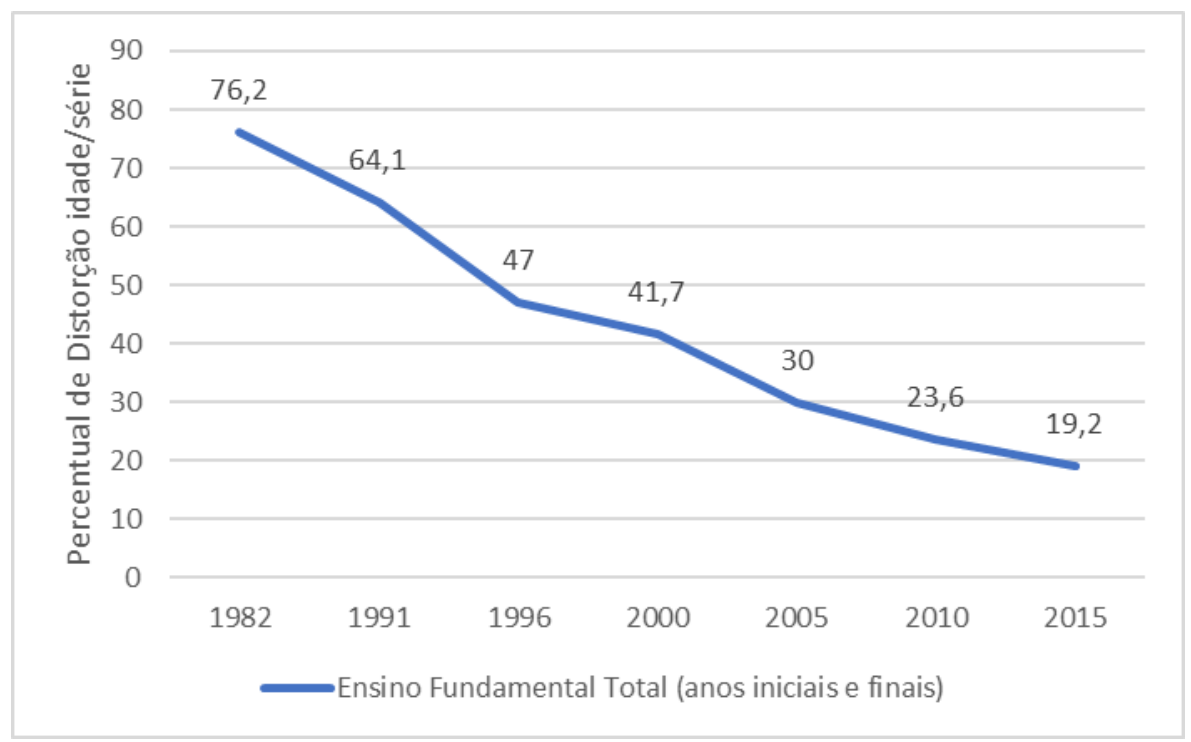

Fonte: IBGE, Séries históricas e estatísticas

\footnotetext{
${ }^{9}$ Dentre essas, destacam-se o Centro de Ensino Tecnológico de Brasília (CENTEB) e o Centro de Estudos e Pesquisas em Educação, Cultura e Ação Comunitária (CENPEC).

${ }^{10}$ É importante destacar que, paralelamente às políticas de correção de fluxo e aceleração da aprendizagem para alunos multirrepetentes, também foram implementadas políticas de não reprovação e progressão continuada, a exemplo dos ciclos de formação / aprendizagem mencionados. Essas iniciativas também contribuíram para a redução das taxas de distorção idade/série observadas.
} 
Em relação ao compromisso pedagógico desses programas, isto é, à recuperação da aprendizagem por parte dos alunos em atraso escolar (e, com isso, de sua autoestima), as pesquisas apontam para conclusões mais complexas. Prado (2000), ao mencionar a pesquisa realizada pela Fundação Carlos Chagas (FCC) em 1998, encomendada pelo IAS sobre o impacto do Programa de Aceleração da Aprendizagem, aponta resultados positivos do programa: aproximadamente $45 \%$ dos alunos advindos de classes de aceleração puderam ser reenturmados em turmas regulares. Contudo, reconhece que a recuperação da autoestima dos alunos multirrepetentes, bem como a mudança comportamental desejada por parte dos professores em relação à cultura da repetência apresentaram resultados menos satisfatórios. Lalli (2000), fazendo referência às avaliações externas aplicadas pela mesma Fundação, afirma que na maioria dos municípios os alunos avaliados demonstraram, em média, “desempenho comparável à média nacional do Sistema Nacional de Avaliação da Educação Básica (Saeb)” (p. 145). Acrescenta, ainda, que os índices de aprovação em 1998 dos egressos do programa em 1997 foram semelhantes àqueles obtidos pelos alunos que continuaram em turmas regulares.

Placco, André e Almeida (1999), por meio de um estudo de caso realizado em seis escolas no Estado de São Paulo, apresentam percepção semelhante quanto ao desempenho dos egressos do programa em relação aos alunos das turmas regulares. A comparação entre o desempenho dos alunos egressos e não egressos das classes de aceleração, enturmados na $4^{\mathrm{a}}$ e $5^{\mathrm{a}}$ séries à época da pesquisa, tendo como base as avaliações de Português e Matemática do SAEB (1994) e do SARESP (1997), aponta para resultados relativamente próximos. No entanto, as autoras mencionam que não são poucos os alunos egressos que chegam às turmas regulares semialfabetizados, uma percepção confirmada pelos professores entrevistados. Além disso, a aplicação de testes de autoestima ${ }^{11}$ permitiu verificar que os alunos egressos das classes de aceleração apresentavam níveis mais elevados de baixa autoestima do que os não egressos, uma conclusão que ecoa a constatação de Prado (2000).

\footnotetext{
${ }^{11}$ Como pontuado por Placco, André e Almeida (1999, p.63), o teste de autoestima aplicado "constou de uma adaptação do Measures of Self-Concept, grades $k$-12, elaborado pelo Instructional Objectives Exchange, de Los Angeles, Califórnia (edição revista de 1972), gentilmente cedido pelo Núcleo de Avaliação Educacional, da Fundação Carlos Chagas”. O objetivo por trás de sua aplicação era "identificar as atitudes dos alunos em relação a si mesmos, aos colegas, à tarefa de casa e à escola, entre outras".
} 
Análises do processo de implementação desses programas em diferentes estados e municípios, como as de Parente e Lück (2004, 2007), também sugerem que os objetivos previstos podem não ter sido plenamente atingidos em todos os casos, tendo em vista diversas dificuldades identificadas ao longo desse processo. Dentre os fatores apontados pelas autoras, encontram-se a falta de assistência aos diferentes níveis de gestão, a insuficiência de recursos materiais e pedagógicos, às vezes por falhas de planejamento e organização, problemas atribuídos ao corpo discente (agressividade, violência, evasão e absenteísmo) e direcionamento de alunos sem o perfil recomendado para as turmas do programa. Além disso, ganha destaque a resistência dos agentes escolares em relação a essas turmas, decorrente da dificuldade em lidar com os alunos que eram público-alvo da política, considerados indisciplinados e desmotivados. Nesse sentido, vale lembrar que o resgate da autoestima desses alunos consistia em um importante aspecto do programa, sendo considerado elemento necessário para seu sucesso. Dessa forma, assumia-se a importância de que "os profissionais envolvidos, principalmente os professores, desenvolvam uma expectativa positiva em relação ao aluno" (PARENTE e LÜCK, 2004, p. 31), o que por vezes se apresentou como um desafio na implementação desses projetos.

Por fim, o mapeamento realizado pelas autoras, que caracterizou um dos primeiros trabalhos sobre os programas de aceleração da aprendizagem implementados na década de 1990, apontou o baixo monitoramento e avaliação desses processos. Dessa forma, a continuidade, descontinuidade ou alteração dessas políticas acabavam sendo decididas com base em opiniões e observações isoladas, em vez de resultarem de uma análise sistemática quanto à eficácia do que vinha sendo feito. Como será visto na seção a seguir, o desenvolvimento de políticas de correção de fluxo não se esgotou na década de 1990, adentrando os anos 2000, quando a regularização do fluxo escolar ganhou ainda mais importância.

\section{2.}

\section{A correção do fluxo escolar nos anos 2000: a integração da equidade à qualidade}

Conforme pontuado por Lima (2016), diversos fatores concorreram para a incorporação dessas políticas na agenda educacional de diversas redes de ensino, 
já na primeira década do novo milênio. Dentre eles, encontra-se a apresentação do Plano de Desenvolvimento da Educação (PDE) e sua aliança com o "Plano de Metas Compromisso Todos pela Educação" em 2007, e a criação e divulgação do Índice de Desenvolvimento da Educação Básica (IDEB) no mesmo ano. Esse último, ao integrar tanto o desempenho cognitivo dos estudantes (medido por meio da Prova Brasil, instituída em 2005) quanto o rendimento escolar (o fluxo, calculado a partir de dados do Censo Escolar) respalda um conceito de qualidade educacional baseado em eficácia e equidade.

Para que se possa compreender o contexto brevemente descrito acima, em que essas políticas ganharam nova força, propõe-se o seguinte esquema gráfico, elaborado a partir das informações apresentadas na tese de doutorado de Maria de Fátima Lima (2016):

Figura 1: Aliança PDE e Plano de Metas Todos Pela Educação

\begin{tabular}{|c|c|}
\hline $\begin{array}{l}\text { 2007: Renovação da } \\
\text { Agenda Política no } \\
\text { Governo Lula }\end{array}$ & Plano de Aceleração do Crescimento (PAC) \\
\hline Plano de Ações Articuladas (PAR) & $\begin{array}{l}\text { Plano de Desenvolvimento da Educação (PDE) } \\
\text { Instrumento estratégico para viabilizar o Plano Plurianual (PPA 2008-2011), } \\
\text { buscando articular duas das oito prioridades apresentadas pelo plano: a } \\
\text { elevação da qualidade da educação e a redução das desigualdades } \\
\text { regionais }\end{array}$ \\
\hline $\begin{array}{l}\text { Planejamento estratégico voltado aos } \\
\text { estados e municípios que aderem ao } \\
\text { compromisso com as diretrizes do Plano } \\
\text { de Metas. Dimensões que orientam o }\end{array}$ & $\begin{array}{c}\text { Aliança PDE + Plano de Metas Compromisso Todos pela Educação } \\
\text { (Decreto } 6094 \text { de } 24 \text { de abril de 2007) }\end{array}$ \\
\hline $\begin{array}{l}\text { planejamento: } \\
\text { 1) Gestão educacional } \\
\text { 2) Formação de Professores e } \\
\text { profissionais de serviço e apoio escolar } \\
\text { 3) Práticas Pedagógicas e Avaliação } \rightarrow \text { C.F } \\
\text { 4) Infraestrutura Física e Recursos } \\
\text { Pedagógicos }\end{array}$ & $\begin{array}{l}\text { Colaboração entre a União, os estados e os municípios - apoio técnico e } \\
\text { transferências do MEC condicionados à adesão ao PDE e ao compromisso } \\
\text { com as } 28 \text { diretrizes estabelecidas no Decreto, referenciadas no IDEB } \\
\text { (integrado ao Plano de Metas) }\end{array}$ \\
\hline
\end{tabular}

Fonte: Elaboração da autora, com base em informações organizadas por LIMA (2016)

Como pode-se depreender do esquema, mecanismos de correção de fluxo estão inseridos na dimensão "Práticas Pedagógicas e Avaliação" do PAR. Este era usado como parâmetro para as transferências financeiras e apoio técnico prestado pelo MEC aos entes federados que se comprometessem a cumprir as diretrizes do Plano de Metas, no sentido de melhorar seus indicadores educacionais. Após uma avaliação diagnóstica realizada pelo estado ou município, apoio técnico ou financeiro poderia ser obtido junto ao MEC a partir do cadastramento de uma 
tecnologia educacional relacionada à correção de fluxo, dentre aquelas apresentadas no Guia de Tecnologias Educacionais.

No ano de 2009, quando se iniciou a implementação dos projetos de correção de fluxo no município do Rio de Janeiro focalizados nesta pesquisa, 94\% das tecnologias educacionais voltadas à correção de fluxo apresentadas no Guia eram promovidas por instituições externas (LIMA, 2016). Nesse sentido, pode-se dizer que o PAR contribuiu para a ampliação das parcerias público-privadas na prestação de serviços e soluções educacionais, aumentando a influência desses setores na gestão educacional. Cabe ressaltar, no entanto, que os entes federados dispõem de autonomia para desenvolver e implementar as próprias políticas e programas que julgarem adequados. De qualquer sorte, dada a importância que a correção do fluxo adquiriu com a integração do rendimento às metas de qualidade a serem alcançadas pelo IDEB, diversos estados e municípios se viram induzidos a implementar essas políticas.

Após uma breve elucidação do cenário em que se desenvolveram as políticas de correção de fluxo após a década de 1990, finalizamos esta seção com a revisão de alguns dos trabalhos que tratam da implementação desses programas já nesse contexto mais recente. A escolha desses trabalhos partiu de uma pesquisa exploratória inicial ao Banco de Teses e Dissertações da Capes, elegendo como palavras de busca os termos "correção de fluxo" e "aceleração da aprendizagem". Os resultados foram filtrados de modo a apresentar os trabalhos produzidos nos últimos cinco anos (2012, 2013, 2014, 2015 e 2016), nos programas de pósgraduação em Educação. Como os termos eleitos estão relacionados entre si e costumam ser empregados conjuntamente em diversas pesquisas, os resultados apontados pela busca foram comparados um a um, de modo a eliminar eventuais repetições. Chegou-se, portanto, ao número de 29 trabalhos $^{12}$, que constituem em sua grande maioria análises qualitativas com a predominância de estudos de casos. Para uma análise mais detalhada, escolheram-se três desses estudos, cada um deles conduzido em um estado diferente (Minas Gerais, Santa Catarina e Rio de Janeiro).

\footnotetext{
${ }^{12}$ A quantidade de trabalhos desenvolvidos nos últimos cinco anos a respeito dessa temática indica que ela permanece atual nos debates educacionais, abarcando uma multiplicidade de olhares e tratamentos.
} 
Barbosa (2013) buscou investigar a efetividade da implementação do Projeto Acelerar Para Vencer (PAV) em uma escola no município mineiro de São João del-Rei que obteve bons resultados relacionados à política, segundo o PROEB (Programa de Avaliação da Rede Pública de Educação Básica), avaliação externa estadual de Minas Gerais. Para isso, realizou observação não participante, grupo focal e entrevistas com professores do projeto, com o diretor da escola e com especialistas da educação básica, além de aplicar questionários para alunos e pais. Sua análise constatou que o projeto, cujo propósito era o aumento da proficiência e a redução da distorção idade-série dos alunos com pelo menos dois anos de atraso escolar, não atingiu seus objetivos. Dentre os fatores que concorreram para esse resultado estão: uma implementação pouco democrática (“de cima para baixo"), a ausência de um perfil pedagógico por parte do gestor escolar, a dificuldade dos professores em aceitar a proposta de progressão continuada, e o desconhecimento de diversos agentes que atuavam com o projeto em relação aos seus documentos norteadores. Quanto à resistência dos professores (apoiada pelo diretor) em relação ao regime de progressão continuada, a autora observa que esses agentes a responsabilizam pela falta de compromisso dos alunos, dado que não se esforçavam para estudar porque estavam certos da sua aprovação. Consequentemente, observava-se uma baixa expectativa dos professores em relação a eles e uma "banalização curricular" em sala de aula, elementos que contribuíam para que os alunos, quando reintegrados nas turmas regulares, sofressem novas reprovações e novo aumento na distorção idade-série.

Gris (2015) analisa a implementação de um programa de correção de fluxo desenvolvido pela Secretaria Estadual de Educação de Santa Catarina em 2012. O objetivo do programa era corrigir a defasagem idade-série dos alunos nos anos finais do ensino fundamental e recuperar sua aprendizagem, de modo que pudessem concluir essa etapa de ensino e ingressar no Ensino Médio com permanência e aproveitamento assegurados. Para tal, a autora realizou um estudo de caso em uma escola estadual localizada no município de Formosa do Sul, lançando mão de entrevistas com 16 sujeitos (gestores, professores e alunos participantes do projeto), de modo a compreender a repercussão do programa no processo de escolarização desses alunos. Quanto a esse ponto, o programa mostrou-se bem-sucedido no sentido de que os alunos participantes permaneceram na escola em 2012, tendo concluído o Ensino Fundamental nesse ano. Contudo, 
na percepção dos docentes, a aprendizagem não teria sido uma prioridade da política de correção de fluxo, visto que sua aprovação já estava assegurada contanto que uma frequência mínima fosse atingida. Nesse sentido, percebiam no programa uma iniciativa imposta à escola com o intuito de melhora dos índices da educação estadual, sem um envolvimento efetivo da comunidade escolar em sua elaboração, e sem uma preocupação genuína com o aproveitamento escolar dos alunos. No tocante a esse aspecto, os professores consideram que a matriz curricular do programa não incorporou todos os conhecimentos necessários para que os alunos pudessem prosseguir bem no Ensino Médio. A autora constata, ainda, o preconceito e a discriminação contra os alunos que integravam as turmas de correção de fluxo durante a implementação do programa. O mau comportamento atribuído a esses alunos, aliado ao histórico de reprovação e à dificuldade de aprendizagem que apresentavam, concorriam para uma baixa receptividade do programa por parte dos professores. Por parte dos alunos, por outro lado, percebia-se uma boa receptividade por conta da oportunidade de uma conclusão mais rápida dessa etapa de ensino.

Nesse sentido, vale mencionar o trabalho de Almeida (2015), centrado nas percepções dos alunos já marcados por uma trajetória de fracasso escolar, que chegam ao Ensino Médio e são incluídos em um programa de correção de fluxo nessa etapa de ensino. Por meio de um estudo de caso realizado em uma escola estadual localizada no município de Belford Roxo, o autor analisa os ganhos percebidos por esses alunos relativos à experiência de participar do projeto. Seus achados apontam, mais uma vez, para a "inclusão subalterna" oferecida por esses programas, no sentido de que não são capazes de recuperar o atraso escolar desses alunos em termos de aprendizagem, para além de regularizarem seu fluxo e acelerarem sua saída do sistema educacional. A aceleração de sua terminalidade, por sua vez, parece ser também o principal ganho percebido pelos próprios alunos inseridos nessas turmas. Da mesma forma que muitas vezes esses projetos são percebidos como uma forma de se "livrarem dos alunos problemas", os próprios alunos os enxergam como atalho para "se livrarem da escola". O autor chama atenção, ainda, para o foco socializador do projeto implementado, em detrimento da priorização do processo de ensino-aprendizagem, o que condiz com a percepção de muitos agentes na comunidade escolar quanto à necessidade de "docilizar" esses alunos considerados indisciplinados. Percebe-se, nesse ponto, a 
permanência de uma dualidade de ensino, uma vez que, para esses alunos, a principal função da escola parece ser a garantia de sua disciplina, de sua capacidade de obediência, e não tanto de um processo de ensino-aprendizagem.

Dentro dos limites da revisão de literatura empreendida neste trabalho, pôde-se perceber que alguns achados de pesquisas que tratam das políticas de correção de fluxo e sua implementação em diversos contextos, desde a década de 1990, se mostram bastante recorrentes. A conclusão mais geral apontada por esses estudos é a de que a implementação e os resultados desses programas nem sempre correspondem às intenções previstas na etapa de formulação. Ao passo que o objetivo de correção do fluxo escolar por meio da redução na distorção idade-série se mostrou passível de alcance em diversas experiências, a mesma facilidade não foi encontrada no que respeita ao objetivo pedagógico e à dimensão de equidade que preveem essas políticas. Em outras palavras, muitos parecem ter sido os fatores limitantes para que os alunos que vivenciaram múltiplas reprovações conseguissem superar sua dificuldade e dar continuidade ao seu processo de escolarização sem perdas significativas de aprendizagem e sem passar por novos fracassos.

Esses fatores incluem problemas estruturais relativos à ausência ou insuficiência de recursos materiais e pedagógicos para que se conduza uma prática de ensino-aprendizagem verdadeiramente diferenciada, bem como a falta de apoio, capacitação e monitoramento apropriados. Incluem, ainda, problemáticas relativas aos próprios órgãos centrais e/ou parceiros que desenvolvem as políticas. O objetivo priorizado parece ser a melhora dos indicadores educacionais por meio da correção do fluxo, sem uma preocupação à altura com a aprendizagem dos alunos em atraso escolar.

No entanto, os fatores limitantes incluem também questões relacionadas à forma como os agentes implementadores diretos - professores, gestores e demais membros da comunidade escolar - percebem a proposta de progressão continuada e, principalmente, os alunos que constituem o público-alvo dessas políticas. Nesse sentido, percebe-se a manutenção de uma cultura da repetência baseada em pressupostos que condicionam o interesse do aluno no seu processo de aprendizagem ao risco de reprovação a que está sujeito. Além disso, percebe-se a predominância da identificação do aluno em atraso escolar como aquele mais indisciplinado, rebelde e difícil de ensinar, fazendo com que se adotem outras 
prioridades em relação a ele. Trata-se, portanto, de compreensões mais personalistas que, como mencionado por Gris (2015), podem ir de encontro à proposta republicana de escolarização compreendida como processo de formação por meio do conhecimento. Podem levar, ainda, à "degradação da oferta de um direito" como pontuado por Almeida (2015). Por conta de todos esses fatores, pode-se dizer essas propostas que visavam um tratamento diferenciado ao invés de uma "equidade formal" não se mostraram verdadeiramente diferenciadas em sua implementação, acabando por reproduzir a situação de fracasso.

Conclusões como essas contribuíram para que a presente pesquisa elegesse como foco de análise os agentes implementadores diretos dessas políticas no nível da escola e suas percepções. Busca-se compreender como processos de ressignificação acerca da proposta e dos alunos que são seu público-alvo podem afetar as práticas que configuram sua implementação. Abre-se espaço, portanto, para que se recorra a mais um referencial teórico-metodológico para a instrumentalização da análise proposta: os estudos sobre implementação de políticas públicas e sobre os agentes implementadores da linha de frente. Passamos, então, à próxima seção.

\section{3.}

\section{A implementação de políticas públicas com foco nos agentes: a burocracia do nível da rua e a organização educativa}

Como ocorre com qualquer tentativa de delimitação, o conceito de "política pública” conta com diferentes definições. Na revisão de literatura empreendida por Souza (2006), a autora busca sintetizar as contribuições de diversos autores ao apresentar a seguinte compreensão do termo:

o campo do conhecimento que busca, ao mesmo tempo, "colocar o governo em ação" e/ou analisar essa ação (variável independente) e, quando necessário, propor mudanças no rumo ou curso dessas ações (variável dependente). (SOUZA, 2006, p. 26)

Considerando a amplitude da ação governamental em questão, que pode dirigir-se a diferentes áreas da vida social como educação, saúde, segurança etc, o campo de conhecimento de que trata a política pública torna-se igualmente amplo. Dessa forma, Souza (2006) destaca o aspecto holístico da área, que não mais se encontra restrita à Ciência Política, passando a comportar diferentes "olhares". A definição proposta pela autora indica, ainda, a possibilidade de que o tratamento 
analítico da ação governamental seja acompanhado por uma base normativa. Trata-se de dimensão também apontada por outros autores como bastante recorrente nos estudos sobre políticas públicas, que muitas vezes buscam entender processos político-administrativos de forma a propor soluções melhores para eles (MAJONE e QUADE, 1980). Nesse sentido, buscaremos neste trabalho oferecer um "olhar" para o campo advindo dos estudos em Educação, que busque compreender e refletir a respeito de determinada política educacional, sem uma pretensão normativa de propor mudanças explícitas no curso dessa ação.

No que diz respeito aos estudos realizados nesse campo, autores como Lima e D’Ascenzi (2013) e Lotta (2014) chamam atenção para um ponto de partida comumente adotado por pesquisadores de forma a recortar seu objeto de análise. Trata-se de uma divisão das políticas públicas em fases, que comumente englobam: agenda, formulação, implementação e avaliação. Embora nem sempre essas etapas sejam bem delimitadas, visto que muitas vezes se mesclam e se sobrepõem, a abordagem conhecida como "ciclo de políticas públicas" pode servir como um recurso útil para a compreensão do objeto.

Nessa concepção, a agenda configura a etapa em que determinados temas ganham relevância no debate público e são incluídos nas plataformas eleitorais de diferentes governos. A formulação, por sua vez, diz respeito à tradução dessas plataformas em planos de ação que buscam modificar determinada situação. Já a implementação corresponde à colocação em prática dos programas e projetos delineados, que passam, então, a estar submetidos a processos de avaliação. Estes, por fim, buscam aferir os resultados da execução das propostas e intenções previamente formuladas (SOUZA, 2006; LOTTA, 2010). Tendo em vista que o processo de implementação constitui objeto de interesse do presente trabalho, cabe discutir brevemente o enfoque que vem sendo atribuído a ele nos estudos sobre políticas públicas, bem como algumas das principais abordagens que se desenvolveram para sua análise.

Em uma revisão sobre os estudos de implementação realizados nas três décadas anteriores ao seu trabalho, Barrett (2004) aponta que até os anos 1970 as análises de políticas públicas estavam centradas no processo de decisão e elaboração das políticas. Isso se devia à percepção de que havia uma separação nítida entre a esfera política, onde se encontravam os tomadores de decisão, e a esfera administrativa, na qual atuava uma burocracia subordinada, o que remete a 
uma perspectiva weberiana clássica. Dessa forma, a implementação era concebida como um processo técnico, uma execução das diretrizes impostas por meio de um processo hierárquico. Visto que era tida como consequência, a compreensão da trajetória de implementação devia remeter ao processo no qual se originou, ou seja, à etapa de formulação (LIMA e D'ASCENZI, 2013).

No entanto, já a partir do final da década de 1960 e início dos anos 1970 uma preocupação crescente com a efetividade das políticas públicas e avaliação de seus resultados começava a ser observada (BARRETT, 2004). Como pontuado por Oliveira (2012), passou-se a se preocupar com aquilo que de fato importava na ótica do cidadão, ou seja, os efeitos que as políticas tinham para as pessoas e os problemas aos quais se dirigiam. Nesse sentido, Barrett (2004) menciona que os estudos avaliativos começavam a apontar a problemática que envolvia a implementação, identificando determinados fatores-chave que contribuíam para que houvesse falhas nesse processo. Dentre esses elementos, mais detalhadamente analisados por autores como Pressman e Wildavsky (1984) e Sabatier e Mazmanian (1979), segundo Barrett (2004, p. 252), estavam: a falta de clareza nos objetivos das políticas, o que dava margem a diferentes interpretações e ações discricionárias; uma multiplicidade de atores e agências envolvidos na implementação, podendo gerar problemas de comunicação e coordenação entre eles; diferenças entre os interesses e valores inter e intraorganizacionais dos atores e agências, o que poderia afetar as interpretações da política e as motivações para implementá-la; e a discricionariedade das agências implementadoras, que limitava o controle administrativo.

A partir de constatações como essas, novas perspectivas de análise que se debruçavam sobre a política em ação passaram a contestar a visão tradicional segundo a qual a implementação constituía um estágio hierarquicamente inferior e subordinado à etapa de formulação. Nesse sentido,

Sugeriu-se que a implementação deveria ser considerada uma parte integral e contínua do processo político, em vez de uma sequência administrativa, e ser vista como uma dialética entre política e ação envolvendo negociação e barganha entre aqueles que buscam pôr a política em ação e aqueles de quem a ação depende. (BARRETT, 2004, p. 253) ${ }^{13}$

\footnotetext{
13“It was suggested that implementation should be regarded as an integral and continuing part of the political policy process rather than an administrative follow-on, and seen as a policy-action dialectic involving negotiation and bargaining between those seeking to put policy into effect and those upon whom action depends." (BARRETT, 2004, p. 253)
} 
Essas novas abordagens que tratavam a implementação como negociação passaram a levar em conta os agentes implementadores, envoltos em estruturas e relações de poder dentro das quais engajavam-se em processos de barganha, buscando também proteger seus valores e interesses. Como pontua Lotta (2014), os estudos de implementação voltaram-se, então, à compreensão do que acontecia nesse processo, em vez de questionarem a conformidade da implementação com os pressupostos nos quais se baseava. A partir de então, "duas abordagens hegemônicas" (LIMA e D'ASCENZI, 2013, p. 102) vêm se mostrando como modelos básicos na análise da implementação de políticas públicas: top-down e bottom-up.

A primeira abordagem mantém sua base na separação entre as esferas política (da decisão) e administrativa (da operacionalização) mencionada anteriormente. Dessa forma, o foco recai sobre o processo de formulação da política pública, de modo que sua estrutura normativa é tida como o parâmetro de sucesso da implementação. Para assegurar que os objetivos definidos sejam atingidos, mecanismos de controle e regulação da discricionariedade dos agentes implementadores - vista como uma distorção da autoridade hierárquica - tornamse centrais para evitar falhas nesse processo. Esses estudos buscam, portanto, identificar razões para o fracasso de determina política, sempre julgado relativamente ao alcance dos objetivos anteriormente estabelecidos, e propor formas de garantir a conformidade entre execução e formulação. Citando Elmore (1996), Lima e D’Ascenzi (2013) apontam que o maior problema desse modelo é o suposto implícito no qual se baseia, que prevê o controle por parte dos formuladores sobre os processos organizacionais, políticos e tecnológicos que influenciam a implementação. No entanto, como afirmam Silva e Melo (2000), as pesquisas empíricas indicam uma dinâmica bastante distinta, em que os objetivos se mostram ambíguos, a coordenação apresenta-se problemática, os recursos são limitados e a informação é escassa.

Já a segunda abordagem compreende o processo de criação de políticas como "um processo iterativo de formulação, implementação e reformulação" (MAZMANIAN e SABATIER, 1983, p. 9), o que torna a implementação mais do que um estágio sequencial no processo de evolução da política. Nessa perspectiva, presume-se que a política e suas próprias intenções se transformam ao longo da 
execução, a qual passa a assumir uma dimensão criativa, não mais restringindo-se à operacionalização técnica. Assim sendo, o parâmetro de sucesso torna-se menos rígido, já que os objetivos e planos iniciais ganham importância relativa diante da ênfase posta sobre os processos, dos quais dependem os resultados. Dessa forma, o modelo bottom-up chama atenção para os agentes implementadores, que passam a constituir "variável explicativa" desse processo. Ao empregar sua discricionariedade - vista como um mecanismo adaptativo inevitável, e por vezes até mesmo desejável - esses agentes podem adaptar a política pública às circunstâncias da implementação, levando a diferentes resultados.

Considerando que os agentes implementadores ganham um papel de destaque no segundo modelo, é fundamental trazer a contribuição de Michael Lipsky para esse debate, dado o amplo estudo que realizou sobre a burocracia implementadora em sua obra Street-Level Bureaucracy (1980). Lipsky (1980) nomeia como "burocratas do nível da rua" os agentes da linha de frente do serviço público, aqueles que interagem diretamente com os cidadãos no decorrer de seu trabalho, e que dispõem de significativa discricionariedade na execução de suas atividades (LIPSKY, 1980, p. 3). O conceito de discricionariedade é entendido pelo autor como a relativa liberdade que esses agentes têm para determinar a natureza, a quantidade e qualidade dos benefícios e das sanções a serem oferecidos pelas suas agências a esses cidadãos (ibidem, p. 13). Exemplos desse tipo de burocratas incluem, entre outros, professores, assistentes sociais, policiais e demais responsáveis pela aplicação da lei, que tornam o Estado concreto para os cidadãos na medida em que lhes concedem acesso a programas e direitos governamentais e ao serviço público em geral.

Ao influenciar a elegibilidade dos cidadãos no acesso a benefícios e/ou no recebimento de punições, os burocratas da linha de frente têm um impacto direto em suas vidas e oportunidades. O exercício de sua discricionariedade ocorre não porque não haja normas que os constranjam, mas porque nem sempre as regras formais dão conta de todos os casos com que esses funcionários lidam, bem como muitas vezes os recursos são escassos para a prestação de determinado serviço. Soma-se a esses fatores a imprevisibilidade de seu trabalho, visto que muitas vezes precisam tomar decisões sob pressão direta do público e sem o mesmo tempo de que dispõem os formuladores de políticas para tal. 
O exercício dessa discricionariedade contribui para que esses agentes deixem de ser apenas executores de políticas para serem também criadores delas próprias. Nas palavras de Lipsky (1980):

Eu argumento que as decisões dos burocratas do nível da rua, as rotinas que eles estabelecem, e os recursos que inventam para lidar com incertezas e pressões de trabalho efetivamente se tornam as políticas públicas que atualizam. Eu sustento que a política pública não é melhor compreendida como sendo feita nas legislaturas ou nas suítes do último andar dos administradores do alto escalão. Essas arenas de decisão certamente são importantes, mas não representam todo o quadro. A essa mistura de locais onde as políticas são feitas, é preciso acrescentar os escritórios lotados e os encontros cotidianos dos trabalhadores do nível da rua. (LIPSKY, 1980, p. xviii) ${ }^{14}$

Cumpre destacar que a discricionariedade desses agentes é compreendida de diferentes formas, como já sugerido na breve explicação dos dois principais modelos analíticos acima. Em uma apreensão negativa do termo, ela aparece como um entrave à observância das regras legitimamente formuladas pelos tomadores de decisão, que foram democraticamente eleitos e que respondem diretamente pelos resultados das políticas. Por outro lado, pode ser vista de forma positiva, representando o potencial criativo dos agentes da linha de frente para enfrentar as diversas contingências que caracterizam a implementação, buscando ajustar as políticas ao contexto de execução ou, ainda, torná-las mais significativas para o usuário (TUMMERS e BEKKERS, 2014). Como Lipsky (1980, xiv) pontua, na melhor das hipóteses, esses agentes criam formas de processamento que lhes permitem lidar com o público de um modo justo. Na pior das hipóteses, eles se rendem ao favoritismo, à conveniência, e a outras formas de servir aos próprios interesses, como, por exemplo, acelerando a passagem dos usuários pelo sistema.

Entre um polo e outro, discussões atuais partem do princípio de que a discricionariedade é foco de controvérsias, merecendo mais atenção por parte dos pesquisadores que se debruçam sobre a implementação (LOTTA, 2014). Tendo em vista que ela constitui um elemento-chave no presente trabalho, cabe um

\footnotetext{
14 "I argue that the decisions of street-level bureaucrats, the routines they establish, and the devices they invent to cope with uncertainties and work pressures, effectively become the public policies they carry out. I maintain that public policy is not best understood as made in legislatures or topfloor suites of high-ranking administrators. These decision-making arenas are important, of course, but they do not represent the complete picture. To the mix of places where policies are made, one must add the crowded offices and daily encounters of street-level workers." (LIPSKY, 1980, p. xviii)
} 
aprofundamento de seu sentido e o esclarecimento da forma como será abordada ao longo da pesquisa.

Entendemos discricionariedade como "a liberdade percebida pelos burocratas do nível da rua para fazer escolhas relativas ao tipo, à quantidade e à qualidade das sanções e recompensas disponíveis na implementação de uma política" $" 15$ (TUMMERS e BEKKERS, 2014, p. 529 - grifo nosso). Essa definição adotada pelos autores acrescenta àquela de Lipsky (1980) a importância da dimensão perceptiva, ao considerar que as pessoas agem com base nas suas percepções sobre a realidade, e não com base na realidade propriamente dita (LEWIN, 1936). Dessa forma, Tummers e Bekkers (2014, p. 530) pontuam que os agentes podem experimentar diferentes níveis de discricionariedade a depender, por exemplo: do conhecimento que têm sobre brechas nas regras, da forma como sua organização operacionalizou a política, da relação que nutrem com seus superiores, e de sua própria personalidade (de mais "obediente" a mais "rebelde"). Essa perspectiva engloba, portanto, para além de características individuais dos agentes, fatores organizacionais e relacionais que podem influenciar a margem de liberade que os agentes percebem ter ao implementar políticas.

Para além da definição do termo, cabe refletir a respeito do sentido que orienta a ação discricionária desses agentes, ou seja, se ela é exercitada com base em uma busca autointeressada, em uma procura por maior efetividade ou, ainda, como uma estratégia de enfrentamento às limitações encontradas no contexto concreto. Nesse sentido, vale mencionar as duas narrativas sobre o trabalho no nível da rua apresentadas por Maynard-Moody e Musheno (2003), que aprofundam essa discussão. Uma delas (state-agent narrative) representa o agente implementador como um "agente do Estado", a outra (citizen-agent narrative) o representa como um "agente do cidadão".

$\mathrm{Na}$ primeira narrativa, o Estado democrático é representado como um "edifício erguido sobre a lei", que prevê que casos semelhantes recebam tratamento igual. Desvios em relação à lei são aceitos apenas de forma excepcional, quando os trabalhadores adaptam as normas às circunstâncias de um modo consistente com a política e com a autoridade hierárquica, de forma que

15 "We then define discretion as the perceived freedom of street-level bureaucrats in making choices concerning the sort, quantity, and quality of sanctions and rewards on offer when implementing a policy" (TUMMERS e BEKKERS, 2014, p. 529) 
tanto os agentes quanto o Estado que eles representam sejam beneficiados. Nos demais casos, a discricionariedade é vista de forma cínica, sendo exercitada por agentes que visam aos próprios interesses, tornando seu trabalho mais fácil, seguro e prazeroso às custas de um serviço pior.

Já a segunda narrativa, embora reconheça a possibilidade de que os agentes ajam e tomem decisões levando em conta também o próprio interesse, considera que essa é uma representação incompleta do trabalho ao nível da rua. Além disso, apresenta o exercício da discricionariedade não como algo excepcional, mas como um fator característico do trabalho na linha de frente, que surge de uma tensão entre as demandas normativas e as percepções e crenças dos agentes quanto ao que é certo fazer. Maynard-Moody e Musheno (2003), ao analisar histórias contadas por diversos burocratas de rua, mostram que eles são bastante atentos a quem são (ou acreditam ser) os cidadãos atendidos, e que muitas vezes tomam decisões quanto ao quê fazer com base nessa identidade percebida. Dessa forma, mais do que centrado em regras, o trabalho na linha de frente é centrado no cidadão-usuário, sendo os juízos e as decisões dos agentes implementadores mais morais do que legais. A depender de como percebem e constroem a identidade desses cidadãos, os agentes do nível da rua podem proceder de diversas formas. Ao invés de facilitar seu trabalho, podem torná-lo mais difícil para atender àqueles que consideram merecedores. Por outro lado, podem optar por agir de forma estritamente burocrática (como um agente do Estado), fazendo o mínimo necessário. Podem, ainda, oferecer àqueles considerados não merecedores menos do que as próprias normas preveem ou permitem.

Enquanto a primeira narrativa gira em torno de uma fidelidade legal, a segunda diz respeito a uma espécie fidelidade moral ou cultural, que leva em conta os cidadãos considerados dignos ou não de um serviço diferenciado. Mais do que simplesmente adaptar as regras às circunstâncias dos casos concretos, os agentes primeiramente avaliam o cidadão em questão e depois recorrem à política para respaldar sua decisão. Caso não encontrem o suporte legal de que precisam, racionalizam seus julgamentos e decisões com bases em outras formas de legitimação. Dentre elas, está o saber pragmático advindo de sua experiência no nível da rua, muitas vezes considerado superior àquele dos formuladores de políticas, que caracterizam como distantes da realidade da linha de frente. 
É importante dizer que, segundo Maynard-Moody e Musheno (2003), esses dois tipos de narrativas são diferentes, porém não exatamente discrepantes, na medida em que descrevem características coexistentes do trabalho ao nível da rua. Os autores argumentam que a compreensão do agente da linha de frente como um "agente do cidadão" opera de forma bem próxima, ainda que tensa, àquela segundo o qual ele se mostra um "agente do Estado". A tensão surge quando aquilo que é formalmente previsto entra em conflito com suas crenças quanto ao que é certo fazer e/ou melhor para o cidadão em questão, de acordo com a forma como o percebe. É nesse momento que os agentes passam a enxergar seu trabalho mais em termos relacionais do que burocráticos/legais, realizando julgamentos dentro desse contexto das relações que estabelecem com os cidadãos e com os outros colegas de trabalho, e agindo de acordo com eles. Dessa forma, pode-se dizer que as crenças e os valores dos agentes se tornam mais claros em suas ações discricionárias.

A partir desse ponto, propõe-se um diálogo entre essa perspectiva de análise sobre a burocracia no nível da rua e um olhar sobre a escola enquanto organização educativa, aproximando atores escolares e burocratas da linha de frente. Nesse sentido, é possível traçar um paralelo entre a coexistência tensa de duas narrativas sobre o trabalho no nível da rua, proposta por Maynard-Moody e Musheno (2003) acima, e o modo de funcionamento díptico da escola apresentado por Licínio Lima (2011), abordado a seguir.

Partindo dos quatro modelos de análise propostos por Per-Erik Ellström (1983) para as organizações educacionais, Lima (2011) destaca o modelo racional e o anárquico como predominantes na análise organizacional da escola ${ }^{16}$. Em ambos os modelos, a racionalidade e a tomada de decisões assumem um papel central, embora sejam tratadas de forma diferenciada e até mesmo antagônica. No primeiro, também denominado como "modelo burocrático", enfatiza-se a importância da estrutura normativa e formal no funcionamento da escola, e a

\footnotetext{
16 Os outros dois modelos seriam o político e o de sistema social. Como apresentado em Lima (2011), o modelo político é caracterizado por uma diversidade e disputa entre interesses e ideologias e pela ausência de objetivos que sejam consistentes e compartilhados por todos os membros, apesar das tecnologias e dos processos organizacionais serem certos e transparentes. Já no modelo do sistema social, os processos organizacionais são vistos sob a ótica da espontaneidade, dado o caráter mais adaptativo e menos intencional da ação organizacional, e privilegia-se o consenso e a adaptação em detrimento da disputa. Segundo o autor, nenhum desses modelos - considerados "mistos" - predominam no estudo da escola como organização.
} 
consciência dos objetivos a serem alcançados e das tecnologias a serem empregadas. Assim como na perspectiva top-down e na narrativa do state-agent, presume-se que os agentes escolares implementam os programas estabelecidos com base em uma racionalidade instrumental. Fazendo referência a esse modelo, o autor pontua suas limitações ao centrar-se no "plano das orientações para a ação", concebendo a escola como um simples reflexo dos constrangimentos normativos impostos sobre ela. Constrangimentos esses que, quando eventualmente rompidos, são compreendidos como disfunções e desajustamentos.

Essa fixação no plano das orientações para a ação, que reduz a escola à sua dimensão jurídica e formal, acaba por desprezar a análise da própria ação praticada pelos atores, que não se restringe a um quadro hiperformalizado. Buscando um contraponto a esse tipo de explicação, Lima (2011) aponta a utilidade do modelo anárquico, mais especificamente da metáfora "anarquia organizada" criada por Cohen, March e Olsen (1972). Segundo Lima (2011) as organizações educativas podem ser entendidas como anarquias organizadas, ainda que parcialmente, na medida em há ambiguidade e pouca clareza em relação aos seus objetivos, preferências, processos e tecnologias, além de uma participação fluida e pouco articulada entre os agentes. Nesse contexto, além de uma estrutura formal, existem regras e redes informais, menos visíveis e sutis, dentro das quais muitas vezes se observa uma "infidelidade normativa".

Esse conceito apresenta-se como central na obra de Lima (2011), sendo compreendido como um contraponto à conformidade normativa-burocrática comumente considerada como regra/padrão, tal como ocorre na state-agent narrative. Nesse sentido, o autor ressalta que não a considera "como um mero desvio, com caráter de exceção, mas antes como um fenômeno típico que pode caracterizar os atores educativos e a ação organizacional escolar” (p. 70). A ideia de infidelidade normativa se aproxima, dessa forma, da compreensão de discricionariedade dentro da citizen-agent narrative, em que é tida como uma característica típica, e não excepcional, do trabalho no nível da rua.

É possível comparar novamente essas duas perspectivas quando Lima (2011) afirma que a infidelidade normativa pode ser "mais corretamente compreendida se considerada enquanto fidelidade dos atores aos seus objetivos, interesses e estratégias" (idem - grifo do autor). Para o autor, as regras alternativas que são produzidas a partir dessa infidelidade às regras formais são 
"atribuidoras de significados sociais e simbólicos, emergentes das interações dos indivíduos, grupos e subgrupos" (p. 58), representando mais o ator social e menos o ator racional. Dessa forma, esses conceitos se assemelham em certa medida à "fidelidade moral ou cultural" considerada prevalente na citizen-agent narrative.

Além disso, Lima (2011, p. 33) pontua que, ao invés de uma racionalidade técnica que orienta as práticas dos atores, encontra-se uma racionalidade $a$ posteriori, empregada retrospectivamente às decisões já tomadas, de forma a justificá-la. Trata-se novamente de um processo semelhante àquele apresentado por Maynard-Moody e Musheno (2003) na narrativa do citizen-agent, em que o agente de nível de rua primeiramente realiza um julgamento em relação ao cidadão-usuário, a partir do qual toma uma decisão e, então, recorre à política ou a outras bases de legitimação para respaldá-la. Aliás, essa dimensão moral também está presente no modelo anárquico, onde "as decisões parecem sujeitas a juízos de valor, em vez de emergirem como as únicas e as melhores decisões" (LIMA, 2011, p. 30). Assim, a racionalidade objetiva do sistema dá lugar à racionalidade subjetiva dos atores, uma racionalidade de satisfação.

Focalizando as faces racional/burocrática e anárquica como dois extremos de um continuum, Lima (2011) postula que a ação organizacional escolar oscila entre eles, não sendo exclusivamente comandada por nenhum dos dois. Nesse sentido, o autor propõe o modo de funcionamento díptico da escola como organização como fenômeno que melhor a caracteriza. Em outras palavras, na organização escolar,

ora se ligam objetivos, estruturas, recursos e atividades e se é fiel às normas burocráticas, ora se promove a sua separação e se produzem regras alternativas; ora se respeita a conexão normativa, ora se rompe com ela e se promove a desconexão de fato" (LIMA, 2011, p. 51 - grifos do autor).

Conceber a organização escolar e as ações no seu interior dessa forma implica compreender que a escola não é somente uma instância voltada para a reprodução de regras, mas que também se auto-organiza para produzi-las. Trata-se de uma perspectiva que dialoga com a coexistência tensa de duas narrativas sobre o trabalho no nível da rua, proposta por Maynard-Moody e Musheno (2003), em que os burocratas da linha de frente ora agem legalmente como "agentes do Estado", e ora agem moralmente como "agentes do cidadão". Com base nessa compreensão, optou-se por usar os termos "agente" e "ator" de forma intercambiável ao longo deste trabalho. Nesse sentindo, reconhecemos que a 
forma de tratamento do nosso objeto/sujeito de pesquisa ${ }^{17}$ implica a escolha de um paradigma teórico e de uma compreensão da linguagem enquanto construção ou reflexo da realidade (DUBAR, 2004). Retornaremos a essa discussão na seção 4.3, referente à abordagem escolhida para a análise do material qualitativo, que privilegia um tratamento dialético. Por ora, é importante adiantar que compreendemos os indivíduos em questão tanto enquanto agentes de um sistema e atores de uma organização, cuja ação mistura determinação e estratégia, necessidade e liberdade, reprodução e produção.

Partindo desse princípio, quando se trata da implementação da política educacional em tela no nível da escola, pode-se levantar a hipótese de que a medida em que as diretrizes decretadas serão efetivamente cumpridas se encontra entre os extremos de uma total aquiescência e de uma total resistência por parte dos agentes/atores implementadores. Cabe destacar que essa hipótese não se pretende valorativa ou dotada de qualquer expectativa normativa, no sentido de que as ações discricionárias (ou as "infidelidades") observadas serão tidas como desvios negativos em relação ao que previa a política.

O que se pretende a partir das reflexões e aproximações tentadas nesta seção é oferecer subsídio para a análise que se desenvolve a partir do próximo capítulo. Em outras palavras, busca-se uma articulação entre referenciais teóricometodológicos para que se possa compreender a implementação de uma política educacional no nível da escola enquanto organização, a partir das percepções dos agentes/atores implementadores. A opção por esse enfoque nos agentes, cujo papel como "fazedores" de políticas (para além de "executores") vem sendo destacado nos estudos sobre burocracia ao nível da rua, se dá também a partir das considerações de Lotta (2014). A autora, após uma revisão sobre os estudos de implementação de políticas públicas, aponta "quase uma estagnação" sobre a importância dada a essa fase após o trabalho seminal de Lipsky (1980). Nesse sentido, menciona que determinadas questões merecem mais ênfase na literatura, e sugere a incorporação de dois focos de atenção às análises no campo: o olhar sobre a cadeia de agentes envolvidos no processo de implementação

17 Tratando dos desafios que envolvem a objetivação dos sujeitos para seu estudo sociológico, Dubar (2004) cita Bourdieu, Chamboredon e Passeron (1968, p. 64), para quem é a "maldição das ciências do homem ter como assunto um objeto que fala". 
(compreendida como interação) e o olhar para os valores desses atores, que influenciam a construção de suas práticas e o exercício de sua discricionariedade.

A compreensão de implementação como "interação entre atores no interior dos ambientes institucionais e relacionais presentes nas comunidades políticas" (LOTTA, 2014, p. 193) dialoga com a perspectiva de implementação como negociação e barganha mencionada anteriormente. Contudo, além de prever a negociação de interesses, uma perspectiva interacionista também pressupõe a negociação de sentidos que orientam as práticas, e a influência de diversos fatores (institucionais, organizacionais, relacionais) nesse processo, posto que que caracterizam o contexto de interação.

O olhar sobre a cadeia de agentes envolvidos e seus valores é fundamental para que se compreendam as práticas concretas que caracterizam a própria implementação, uma vez que "onde há discricionariedade, há valores individuais" (MEIER e O’TOOLE, 2006, apud LOTTA, 2010). Em uma perspectiva interacionista, no entanto, ultrapassa-se a dimensão individual desses valores, visto que esses são (re)construídos nas sucessivas interações em que os atores se envolvem "no interior dos ambientes institucionais e relacionais" mencionados. Dessa forma, torna-se importante também analisar esses espaços físicos e emocionais ${ }^{18}$ que influenciam a construção das percepções, ideias e valores dos agentes da linha de frente.

Portanto, para compreender as práticas discricionárias dos agentes implementadores de uma política de correção de fluxo em uma escola municipal do Rio de Janeiro, buscou-se: olhar para a estrutura programática que os envolve (a própria política em tela), para o ambiente organizacional em que atuam (a escola selecionada), e para as relações que estabelecem com os diversos atores no seu interior. Dentre essas relações, privilegiaram-se aquelas que os agentes estabelecem com os alunos com atraso escolar (o público-alvo da política), com os outros professores/gestores (demais agentes implementadores no nível da escola), e com o chamado "sistema" (as diretrizes e procedimentos formais da política, e seus implementadores nos escalões superiores). Essa opção se deu com base nas três dinâmicas relacionais-chave (three key relational dynamics) que MaynardMoody e Musheno (2003) apresentam como características do trabalho ao nível da

18 "Physical and Emotional Spaces" (MAYNARD-MOODY e MUSHENO, 2003) 
rua: a relação com o cidadão-usuário, com os colegas da linha de frente, e com o chamado "sistema". Segundo os autores, os agentes implementadores constroem suas percepções sobre a identidade desses atores dentro desses três núcleos de interação principais. A forma como os percebem, por sua vez, é o ponto de partida para que esses agentes formulem seus juízos e valores que podem orientar o exercício de sua discricionariedade.

Finalmente, em se tratando da especificidade da organização em questão (a escola), do foco da política educacional em tela (o fracasso escolar), e da importância de valores no exercício da discricionariedade, propõe-se articular a toda essa discussão as contribuições da Sociologia da Educação. Em particular, busca-se relacionar as práticas concretas dos atores ao longo da implementação da política à perspectiva bourdieusiana sobre a construção do fracasso escolar e sobre o julgamento dos mestres nesse processo. Como apresentado nas seções anteriores, a valorização de um ethos de ascensão social pela escola, de uma "boa vontade cultural", constitui um importante parâmetro segundo o qual os alunos (e suas famílias) que não são herdeiros de uma tradição escolar podem ser avaliados pelos professores. Alunos que não possuam essa postura e atitude valorizadas podem vir a ser considerados responsáveis pela própria situação de fracasso, eximindo a escola de sua responsabilidade quanto ao seu aprendizado e reproduzindo no seu interior uma situação de exclusão social já existente.

Somando-se a essa lógica os poucos recursos e as condições desafiadoras em que operam grande parte das escolas públicas municipais, é possível supor que as decisões quanto aos benefícios/sanções a serem oferecidos levem em conta aqueles possuem ou não esse ethos valorizado. Em outras palavras, a percepção do aluno "merecedor" como aquele que tem interesse e quer aprender, e do aluno "não merecedor" como aquele que "não quer nada", pode tornar-se um importante fator a orientar o exercício da discricionariedade dos agentes implementadores. Essas práticas, por sua vez, podem vir a reforçar a desigualdade no acesso aos poucos recursos no interior da escola, contribuindo para a construção e reprodução desse fracasso social no seu interior.

Dito de outra forma, a depender da organização escolar e de como (inter)agem seus atores, os valores que circulam e predominam no seu interior podem refletir e reforçar crenças já dominantes na sociedade relativas às camadas populares, ou produzir novas crenças e expectativas em relação a elas. Essas, 
muitas vezes consideradas responsáveis pela própria condição, por uma suposta "falta de vontade" de trabalhar (PEREIRA, 1967), constituem os principais cidadãos-usuários do serviço público, incluindo a educação escolar. Dessa forma, a infidelidade normativa (ou fidelidade moral/cultural) no interior da escola, as ações discricionárias e a própria produção de regras alternativas, se orientadas por um senso comum, podem levar à reprodução de uma condição de exclusão. Essa possibilidade reforça a importância do olhar sobre os atores/agentes e os valores que orientam sua discricionariedade.

Para compreender esses atores e suas práticas, buscamos primeiramente compreender os fatores institucionais e organizacionais que influenciam a implementação da política. No próximo capítulo passamos, portanto, à descrição própria política de correção de fluxo em questão e à análise da escola selecionada, onde a política foi implementada. A análise da escola, para além dos dados oficiais, é feita com base na percepção dos agentes entrevistados, de forma que se possa compreender as relações que estabelecem com os outros agentes implementadores no nível local. O capítulo cinco traz suas percepções sobre os alunos que constituem o público-alvo da política e sobre a própria política, dentro das duas outras dinâmicas relacionais em questão (com o cidadão-usuário e com o sistema). Já nesse capítulo, buscamos associar as percepções construídas e alguns exemplos de discricionariedade observados. No último capítulo de análise (capítulo seis) buscamos destacar a relevância que o ethos de ascensão social pela escola assume na percepção de diversos agentes entrevistados, relacionando-o a três "tipos ideais" de ação discricionária reconstruídos a partir das entrevistas. 


\section{4 \\ O caso estudado: correção de fluxo na Escola Sigma ${ }^{19}$}

O presente capítulo está organizado em quatro seções. Na primeira delas, busca-se apresentar a política de correção de fluxo desenvolvida na rede municipal do Rio de Janeiro a partir de 2009. Para tanto, a tese de doutorado de Maria de Fátima Magalhães de Lima (2016) constitui uma referência fundamental. A autora realizou uma ampla reconstituição da política no período de 2009 a 2014, tendo em vista a ausência de documentos oficiais que formalmente instituíssem o programa no seu primeiro ano de implementação. Dessa forma, a autora reuniu portarias, resoluções, publicações em Diário Oficial, e informações de sites para descrever o desenho de cada projeto de correção de fluxo desenvolvido ao longo desses anos, bem como o desenvolvimento da política como um todo no período.

Passamos em seguida à descrição da escola estudada. Nesta mesma seção, apresentamos os projetos realizados na escola de 2010 a 2016, e a seleção dos sujeitos entrevistados na presente pesquisa.

$\mathrm{Na}$ seção seguinte, apresentamos brevemente a abordagem hermenêuticadialética proposta em Minayo (2010) para análise do material qualitativo, que buscamos empregar neste trabalho. Por fim, na última seção, passamos à análise da Escola Sigma já a partir das percepções dos agentes entrevistados. Na análise dessas percepções, procuramos empregar a abordagem analítica mencionada.

\section{1.}

\section{A política de correção de fluxo implementada no município do Rio de Janeiro}

Para que se possa melhor compreender a política de correção de fluxo implementada no município do Rio de Janeiro a partir de 2009, iniciamos esta

\footnotetext{
${ }^{19}$ Nome fictício da escola selecionada para a realização do estudo de caso.
} 
seção com uma contextualização da rede pública municipal de educação da cidade e os antecedentes diretos à elaboração da política em tela.

Segundo informações disponibilizadas no site da Secretaria Municipal de Educação, Esportes e Lazer em março de $2017^{20}$, a rede pública municipal de ensino do Rio de Janeiro atendia a 641.655 alunos matriculados em 518 Unidades de Educação Infantil (5 meses a 6 anos) e 1.534 Escolas de Ensino Fundamental $\left(1^{\circ}\right.$ ao $9^{\circ}$ ano). Para atender a esses alunos, a Secretaria englobava nos seus quadros funcionais 41.302 professores e 15.191 funcionários de apoio administrativo, que incluem agentes de Educação Infantil e secretários escolares.

A gestão da rede pública de ensino da cidade se dá em três níveis: o nível central da Secretaria (SME/SMEEL), o nível intermediário composto por 11 Coordenadorias Regionais de Educação (CREs) e as escolas. As CREs são responsáveis pela articulação entre as determinações da SME (no nível macro) e as escolas (nível micro), sendo, portanto, também importantes na implementação das políticas elaboradas pelo nível central.

Como pontua Lima (2016), o foco na avaliação de resultados apresentado na missão ${ }^{21}$ da SME remete a uma importante característica do modelo de gestão que foi inaugurado na rede pública municipal de ensino a partir de 2009, com a entrada do prefeito Eduardo Paes e da secretária de Educação Claudia Costin. Anteriormente à entrada da nova equipe, o ensino na rede era organizado por meio do sistema de Ciclos, implantado na rede municipal do Rio de Janeiro em 2000, por meio do Ciclo de Alfabetização (ou Primeiro Ciclo de Formação como foi denominado), que incorporava as três primeiras séries do Ensino Fundamental e

\footnotetext{
${ }^{20}$ A partir de 2017, com a gestão do Prefeito Marcelo Crivella, a Subsecretaria de Esportes e Lazer foi incorporada à Secretaria Municipal de Educação (SME), que passou a se chamar Secretaria Municipal de Educação, Esportes e Lazer (SMEEL). Os dados apresentados são referentes a março de 2017, e estão disponíveis em: http://www.rio.rj.gov.br/web/smeel/educacao-em-numeros. Acesso em 4 de março de 2017. No restante do trabalho, opta-se pela nomenclatura SME, já que a pesquisa foi realizada anteriormente a 2017.

${ }^{21}$ A missão da Secretaria Municipal de Educação durante o período de implementação da política em tela (2009-2016) foi definida da seguinte forma: "Elaborar a política educacional do município do Rio de Janeiro, coordenar a sua implantação e avaliar os resultados, com o objetivo de assegurar a excelência na Educação Pública no Ensino Fundamental e na Educação Infantil, contribuindo para formar indivíduos autônomos e habilitados a se desenvolver profissionalmente e como cidadãos." (SECRETARIA MUNICIPAL DE EDUCAÇÃO, Conheça a Secretaria 15/08/15, apud LIMA, 2016. p. 63). A partir de 2017, com o início de uma nova gestão, a missão da Secretaria Municipal de Educação, Esportes e Lazer (SMEEL) foi ampliada, sofrendo algumas modificações. O texto atual pode ser encontrado em http://www.rio.rj.gov.br/web/smeel/conhecaa-secretaria. Acessado em 4 de março de 2017.
} 
posteriormente (2007) estendido para todos os anos do Ensino Fundamental (RIO DE JANEIRO, 2007a, p.24). Como pontuam Tura e Marcondes (2001), já na ocasião da implantação do Primeiro Ciclo de Formação, anunciou-se que essa forma de organização dos tempos escolares seria estendida para todo o Ensino Fundamental, assim que essa primeira experiência tivesse sido consolidada.

Diversos foram os estudos que se dedicaram a analisar a implantação do sistema de ciclos de aprendizagem e a reação da comunidade escolar à proposta (FREITAS, 2003; KNOBLAUCH, 2004, FETZNER, 2007, entre outros). Como mostram essas pesquisas, no geral, não foi boa a recepção dos agentes escolares à ideia de não retenção dos alunos, visto que a consideravam prejudicial à sua aprendizagem. Entre os principais pontos levantados pelos autores, destaca-se a ausência de uma verdadeira reorganização da escola ao receber essa inovação, seja por falta de condições materiais e/ou por uma resistência dos próprios agentes a uma cultura de não reprovação. Dessa forma, apesar dos ciclos, a lógica seriada tradicional, baseada na classificação e no ensino homogêneo, teria sido mantida.

Em 2007, a SME implantou mais dois Ciclos de Formação, reunindo no $2^{\circ}$ Ciclo os $4^{\circ}, 5^{\circ}$ e $6^{\circ}$ anos, e no $3^{\circ}$ Ciclo os $7^{\circ}, 8^{\circ}$ e $9^{\circ}$ anos. Dessa forma, só poderia haver retenção de alunos ao final de um ciclo, e não mais no fim de cada ano. Embora já tivesse sido anunciada a possibilidade de expansão dos ciclos para os demais anos do Ensino Fundamental, os professores foram surpreendidos pela mudança e reagiram fortemente a ela (TURA e MARCONDES, 2011). Um dos principais críticos à expansão dos ciclos foi o Sindicato Estadual de Profissionais da Educação (SEPE), que percebia a política como uma forma encontrada pelo governo para reduzir as taxas de repetência e evasão sem, de fato, garantir as condições de trabalho para que a implementação fosse bem-sucedida (LIMA, 2016). Seria uma estratégia, portanto, de redução de gastos com a educação e de maquiagem dos problemas de subinvestimento na área, de falta de professores e de condições adequadas para a garantia da aprendizagem. A política, popularmente identificada como "aprovação automática", passou a ser entendida como uma das principais razões do fracasso do sistema público de ensino. Difundiu-se a percepção de que a medida estaria produzindo analfabetos funcionais, visto que os alunos eram promovidos sem ter aprendido o que era necessário ao longo do ano. 
A polarização do debate sobre a medida e a insatisfação gerada na sociedade como um todo, refletida e alimentada pela mídia, foi exaustivamente debatida no processo eleitoral municipal de 2008, culminando com o compromisso de praticamente todos os candidatos com o fim da "aprovação automática", incluindo o vencedor do pleito Eduardo Paes.

Com a posse do novo prefeito, estabeleceu-se uma nova estrutura políticoadministrativa para a cidade, que Santos (2014) descreve a partir de seu alinhamento aos princípios do Gerencialismo. Nesse modelo de gestão, diferentemente da administração pública burocrática clássica, o Estado assume um papel semelhante ao de um "gerente", enfatizando mais a avaliação de resultados do que a regulamentação de processos. Nesse sentido, o governo que tomou posse em 2009 ficaria conhecido pelo "choque de gestão" que buscou implementar, e pela preocupação com a elaboração de metas e resultados a serem atingidos, com a avaliação do desempenho e políticas de accountability. No tocante à política educacional, foi notável a ruptura com a gestão anterior, principalmente no que diz respeito à "aprovação automática".

Já no dia $1^{\circ}$ de janeiro de 2009, por meio do Decreto 30.340 (RIO DE JANEIRO, 2009a), revogava-se a instituição do segundo e terceiro ciclos de aprendizagem no Ensino Fundamental, que havia sido realizada por meio de decretos anteriores (RIO DE JANEIRO, 2007b e 2007c). Enquanto as duas últimas Secretárias eram professoras de carreira, a nova Secretária Municipal de Educação, Claudia Costin, representava uma escolha externa à área educacional. Formada em Administração Pública, mestre em Economia e doutora em Administração Pública, Claudia Costin havia atuado como Ministra da Administração e Reforma do Estado no governo de Fernando Henrique Cardoso, além de ter exercido outras funções na área de administração. Sua trajetória nas áreas de economia e administração gerou controvérsias e uma recepção crítica por parte de setores diretamente ligados à educação, a exemplo do Sindicato.

O Plano Estratégico da Prefeitura do Rio de Janeiro (RIO DE JANEIRO, 2009b), elaborado para o primeiro mandato do governo Eduardo Paes (20092012) previa um Acordo de Resultados (RIO DE JANEIRO, 2009b) com cada órgão setorial, para que as metas estipuladas pudessem ser atingidas. O Acordo configuraria um incentivo para que os gestores em diferentes níveis tivessem indicadores claros a partir dos quais pudessem orientar seus planejamentos, com 
vistas a alcançar os mesmos objetivos. Nesse sentido, previa-se "premiar por meritocracia aqueles que se destacam na prestação e melhoria do serviço" (RIO DE JANEIRO, 2009c p. 5), buscando um enfoque sobre "resultados, satisfação e efetividade" (idem).

Diante da crise delineada desde a instauração do sistema de ciclos na rede municipal de ensino, que havia mobilizado a opinião pública como um todo por meio de intensa cobertura midiática, a Educação teve uma posição de destaque na agenda do novo governo.

Em 2009, para além da Prova Brasil aplicada nacionalmente, não havia outros instrumentos padronizados de avaliação externa que pudessem realizar um diagnóstico do desenvolvimento dos alunos e criar indicadores de desempenho da rede municipal. A nova gestão da Secretaria decidiu então aplicar uma avaliação diagnóstica nas escolas neste ano, sob a justificativa de que precisava gerar dados para desenvolver uma política educacional que seria implementada na rede a partir daquele ano. A diagnose foi desenvolvida em duas etapas ao longo do mês de março de 2009, após o início do ano letivo. Na primeira etapa, realizada no dia 10/03/2009, aplicou-se uma prova aos alunos do $4^{\circ}$ ao $6^{\circ}$ ano para avaliar sua proficiência de leitura e escrita, que seria classificada de acordo com cinco níveis de alfabetismo. O teste foi produzido pelo Instituto Ayrton Senna e buscava responder de alguma forma ao debate que a política educacional anterior suscitou e ao discurso fortemente difundido nos meios de comunicação de que haveria uma maior "produção de analfabetos funcionais" na rede a partir da política de aprovação automática. A parceria firmada com o Instituto Ayrton Senna (IAS) previa que o Teste Diagnóstico de Alfabetização possibilitasse a posterior inclusão dos alunos nos Projetos Se Liga (para analfabetos funcionais) e Acelera (para alunos com distorção idade-série de dois ou mais anos, de até 14 anos de idade) do IAS. A segunda etapa foi realizada no dia 19/03/2009 e constitui-se de uma segunda prova aplicada aos alunos do $3^{\circ}$ ao $9^{\circ}$ ano, com vistas a avaliar suas dificuldades de aprendizagem em Português e Matemática. Esse teste, ao contrário do anterior, foi produzido pela SME.

O resultado do Teste Diagnóstico de Alfabetização indicou que 28.000 alunos do $4^{\circ}$ ao $6^{\circ}$ ano eram analfabetos funcionais, o que correspondia a $13,6 \%$ da população de alunos nessa etapa (LIMA, 2016). Para além do analfabetismo funcional e dos baixos níveis de aprendizagem, os resultados deram visibilidade 
pública ao expressivo quantitativo de alunos da rede municipal com distorção idade-série. Somente a partir deles que a Secretaria Municipal de Educação passou a divulgar o problema da distorção idade-série como uma questão integrada ao baixo desempenho da rede nas avaliações externas. Observava-se que os alunos que tinham os mais baixos níveis de alfabetização eram, em sua maioria, alunos que tinham defasagem em relação ao ano que cursavam.

A partir desses resultados, elaborou-se um programa que tinha como objetivo a correção do fluxo dos alunos que apresentavam distorção idade-série (e analfabetismo funcional), bem como o reforço escolar permanente, com vistas a recuperar a aprendizagem dos alunos em dificuldade escolar. O Programa Reforço Escolar representou uma das quatro ${ }^{22}$ estratégias estipuladas no Plano Estratégico da Prefeitura (2009-2012) para a área da educação. Contudo, como pontua Lima (2016, p. 83), não houve documentos estruturantes da política no ano de 2009, quando ela começou a ser implementada na rede. A autora então reconstituiu os objetivos e o funcionamento do Programa ao longo dos anos a partir do Portal Rioeduca da Secretaria Municipal de Educação, do Plano Estratégico da Prefeitura (2009-2012), do Plano Plurianual 2011-2013 e das entrevistas realizadas com técnicos da SME e de uma CRE. Baseado no trabalho de Lima (2016) o presente estudo traça uma breve descrição da política, a fim de compreender seu processo de implementação em uma escola da rede municipal selecionada.

De acordo com o Plano Estratégico da Prefeitura (2009-2012), o Programa Reforço Escolar é descrito da seguinte forma:

Este programa vai realfabetizar 28.000 crianças nos $4^{\circ}, 5^{\circ}$ e $6^{\circ}$ anos e oferecer reforço escolar em português e matemática para os alunos do $2^{\circ}$ ao $9^{\circ}$ ano, através de: (i) criação de turmas dedicadas; (ii) contratação e capacitação de professores; (iii) disseminação de metodologias e (iv) desenvolvimento de material de orientação curricular. (RIO DE JANEIRO, 2009b, p. 52)

A redação do Plano deixa clara a existência de duas principais vertentes no Programa: um trabalho de correção de fluxo que visava à "realfabetização" de alunos considerados analfabetos funcionais, e um trabalho de prevenção, voltado à recuperação e manutenção da aprendizagem ao longo do Ensino Fundamental. Dessa forma, as duas medidas que integram o IDEB (desempenho e fluxo) estariam de alguma forma contempladas pela política.

\footnotetext{
${ }^{22}$ As outras três estratégias eram: as Escolas do Amanhã (escolas em espaços conflagrados pela violência urbana), os Espaços de Desenvolvimento Infantil e o programa Saúde na Escola.
} 
Para a redução dos níveis de analfabetismo, no primeiro ano de governo (2009), foram desenvolvidas duas ações em parceria com o Instituto Ayrton Senna: o desenvolvimento do projeto Realfabetização 1 - Se Liga, para alunos do $3^{\circ}, 4^{\circ}$ e $5^{\circ}$ anos considerados analfabeto funcionais; e o projeto Realfabetização 2 - Fórmula da Vitória $^{23}$, para alunos do $6^{\circ}$ ano também considerados analfabetos funcionais. Para o tratamento do problema da distorção idade-série nos anos iniciais, escolheu-se outra tecnologia educacional oferecida pelo Instituto Ayrton Senna, o programa Acelera Brasil.

É interessante chamar atenção para o termo "Realfabetização" (e sua abreviação como "Realfa"), incorporada pela SME aos projetos Se Liga e Fórmula da Vitória do IAS, que tinham como propósito a alfabetização de alunos com defasagem idade-série. Como pontua Souza (2012), cabe refletir sobre a adequação desse nome, visto que o aluno não está sendo "realfabetizado" no projeto, mas sim alfabetizado. Em outras palavras, está aprendendo a compreender e interpretar os códigos linguísticos com os quais não era familiarizado anteriormente, uma vez que, se esses códigos já lhes fossem familiares, não haveria necessidade de uma nova alfabetização.

Em 2009, portanto, foram 3 os projetos de correção de fluxo desenvolvidos na rede municipal do Rio de Janeiro: Realfabetização 1 (Projeto Se Liga, do IAS), Realfabetização 2 (Projeto Fórmula da Vitória, do IAS) e Acelera (Projeto Acelera Brasil, do IAS). Neste primeiro ano de governo do prefeito Eduardo Paes, os projetos de correção de fluxo foram viabilizados através do Programa de Ações Articuladas (PAR), como mencionado na seção 3.2 do capítulo 3. Dessa forma, o governo municipal do Rio de Janeiro aderiu ao Plano de Metas Compromisso Todos pela Educação (aliado ao PDE), realizando uma análise diagnóstica da aprendizagem dos alunos e publicando os resultados do teste - requisitos para a transferência de recursos do MEC para a política educacional a ser desenvolvida. A escolha da tecnologia de correção de fluxo se deu entre os mecanismos cadastrados no Guia de Tecnologias Educacionais do MEC, dentre as quais

\footnotetext{
${ }^{23}$ Como menciona Lima (2016), inicialmente não havia, entre as tecnologias educacionais padronizadas do Instituto Ayrton Senna, uma "solução" para os problemas de analfabetismo e distorção idade/série dos alunos no $6^{\circ}$ ano. Dessa forma, a Secretaria solicitou um novo projeto ao Instituto, o Fórmula da Vitória, que foi denominado como Realfabetização 2 pela SME. Esse projeto teve início no segundo semestre de 2009, diferentemente dos Realfabetização 1 e Aceleração, que se iniciaram já no primeiro semestre do ano.
} 
estavam os projetos do Instituto Ayrton Senna, detentor de metodologia e material próprios.

Como pontua Lima (2016), a nova política de gestão adotada na Secretaria Municipal de Educação a partir de 2009 alinhou-se aos princípios gerais que orientaram a gestão da Prefeitura como um todo, e incluiu mecanismos de responsabilização e publicização dos resultados do IDEB para as escolas. Além disso, foi instituída uma política de avaliação própria da rede municipal em 2009, paralelamente à política nacional (Prova Brasil), que incluía a aplicação de provas externas e internas, e a criação de um índice de qualidade (IDERio), a partir do qual estabeleciam-se metas próprias e bonificação anual. Nesse sentido, como tanto o IDEB quanto o IDERio integram desempenho e fluxo, as políticas de correção de fluxo desenvolvidas no município ganharam destaque. A expectativa que se tinha a partir delas era a de redução da repetência e da taxa de distorção idade-série, contribuindo para a melhora do fluxo e para a recomposição da trajetória dos alunos em situação de atraso escolar.

Em 2010, observou-se a ampliação das parcerias com agentes externos à rede, a partir da entrada da Fundação Roberto Marinho (FRM), proporcionando a extensão dos projetos de correção de fluxo aos anos finais do Ensino Fundamental. Neste ano, os projetos foram formalmente instituídos por meio da Resolução SME 1.079, de 27 de maio de 2010 (RIO DE JANEIRO, 2010b). A partir desse mesmo ano, os contratos com o IAS e com a FRM passaram a ser firmados não mais via PAR, mas diretamente com a SME, o que ampliou a margem de atuação da Secretaria sobre os projetos, materializada, por exemplo, em crescentes adequações nos materiais padronizados disponibilizados pelos parceiros. Para além dos três projetos já implementados em 2009, o novo projeto de correção de fluxo desenvolvido a partir de 2010 foi o Aceleração 2 (Projeto Autonomia Carioca da FRM), que visava à aceleração da aprendizagem para alunos com distorção idade-série nos anos finais do Ensino Fundamental.

A partir de 2010, pôde-se observar um aumento progressivo na quantidade de turmas de correção de fluxo organizadas na rede, bem como sucessivas mudanças pelas quais passou a política ${ }^{24}$. Essas turmas passaram a ser

\footnotetext{
${ }^{24}$ Entre os anos de 2009 e 2014, é possível perceber a introdução de novos projetos a cada ano letivo, alterações nos desenhos dos projetos em relação aos anos anteriores e a incorporação de
} 
denominadas nas escolas e até por agentes da Secretaria e das CREs como "turmas de projeto", um termo que adotaremos neste trabalho ao tratar da percepção dos agentes escolares.

Um dos principais fatores que chamam atenção durante a implementação da política no município desde 2009 é a seleção das escolas que receberiam esses projetos, realizada pela SME. Nesse ponto, cabe destacar a heterogeneidade das escolas que compõem a vasta rede pública municipal do Rio de Janeiro, cuja diversidade estrutural impacta diretamente a gestão escolar (PAES DE CARVALHO et al, 2014). Como pontuado pelas autoras, os recursos de que necessita a gestão escolar para seu bom desenvolvimento - insumos relacionados à infraestrutura, quadro de pessoal e material pedagógico, entre outros - não são distribuídos igualmente entre as escolas. Cabe destacar, ainda, que não raramente se verifica um quadro de escassez desses recursos, principalmente humanos (funcionários administrativos e pedagógicos). Consequentemente, muitas vezes a gestão escolar se encontra sobrecarregada com o trabalho burocrático, e este tendeu a se intensificar a partir da entrada de novos programas e projetos educacionais nos últimos anos. Dessa forma, a dedicação ao trabalho pedagógico propriamente dito, desenvolvido no interior da escola, pode ser prejudicada. Esse aspecto também é destacado por Oliveira (2015), que mostra que, em escolas de maior porte, onde costuma haver maior número de matrículas, turmas e etapas de ensino, a gestão administrativa e pedagógica torna-se ainda mais complexa.

Compreendendo os projetos de aceleração da aprendizagem como uma intervenção pedagógica voltada aos alunos que vivenciaram o fracasso escolar, o envolvimento e o acompanhamento da direção e da equipe pedagógica da escola como um todo torna-se fundamental para o sucesso da proposta (SAMPAIO, 2000; PARENTE e LÜCK, 2007). Nesse sentido, Lima (2016) pontua que os critérios que nortearam a escolha das escolas que organizariam as turmas de correção de fluxo idealmente deveriam privilegiar aquelas cujas dimensões oportunizassem o desenvolvimento dessas estratégias voltadas para o atendimento dos alunos em maior dificuldade, contribuindo para o sucesso da política. No entanto, a seleção na rede municipal do Rio de Janeiro recaiu sobre escolas que

novos grupamentos de alunos. Para uma análise aprofundada desses projetos, pode ser consultada a referida tese de Lima (2016). 
apresentavam maior número de analfabetos funcionais (de acordo com o teste diagnóstico do IAS), elevada distorção idade-série, e salas de aula disponíveis para que as turmas de realfabetização e aceleração fossem organizadas: frequentemente escolas de maior porte ${ }^{25}$ e complexidade da gestão.

Lima (2016) reconhece que tal concentração, por outro lado, provavelmente se explicou pelo desafio que poderia representar a movimentação desses alunos para outras escolas em uma rede como a do Rio de Janeiro. No entanto, fica o questionamento sobre o impacto da implementação desses projetos em escolas nas quais a gestão se encontra comumente sobrecarregada e não necessariamente contava com profissionais que pudessem fazer um trabalho de mediação pedagógica com os professores para a organização do trabalho do Programa na escola. Como será visto nas próximas seções, a escola estudada na presente pesquisa constitui um exemplo desse tipo de escola.

Trabalhando com as bases de matrículas e turmas do Censo Escolar de 2010 a 2014, Lima (2016) mostra de que forma diversos alunos que tinham dois ou mais anos de defasagem idade-série não foram atingidos pela política, ao passo que outros alunos sem o perfil etário exigido foram incluídos em turmas de correção de fluxo. A autora observa que os percentuais de alunos atendidos pela política que não apresentavam a distorção exigida não são desprezíveis, tendo chegado a $54 \%$ em 2010.

A autora ressalta ainda que foram encontradas informações distintas quando se cotejaram os documentos oficiais, as entrevistas com as técnicas da SME e da CRE, e a base de turmas do Censo Escolar. Na base do Censo algumas turmas de correção de fluxo foram preenchidas como turmas Multisseriadas, e outras como turmas regulares do Ensino Fundamental. Esses dados, que podem levar a uma subnotificação das turmas de correção de fluxo organizadas, sugerem a existência de interpretações diferenciadas sobre os projetos e sua finalidade, ou, ainda, certa despreocupação com o preenchimento dos dados oficiais. Como será

\footnotetext{
${ }^{25}$ Categorizando as escolas da rede municipal do Rio de Janeiro conforme o número de alunos matriculados, Lima (2016) propõe quatro "tipos" de escola sob a ótica da complexidade da gestão: escolas de pequeno porte (até 300 matrículas), escola de médio porte (entre 301 e 700 matrículas), escolas de grande porte (entre 701 e 900 matrículas) e escolas de enorme porte (mais de 900 matrículas). Seus achados apontam para a predominância das turmas de correção de fluxo em escolas de grande e enorme porte, com a prevalência daquelas de enorme porte.
} 
visto na próxima seção, situação semelhante parece ter ocorrido com a escola estudada na presente pesquisa. De qualquer sorte, os achados de Lima (2016) apontam para a existência de uma margem de liberdade por parte dos agentes escolares na implementação da política no nível da escola, sobretudo no que diz respeito ao encaminhamento de alunos para essas turmas. Diante disso, este estudo busca contribuir para a compreensão desses eventuais mecanismos, e da racionalidade que os orientam.

A partir do delineamento e da análise realizada por Lima (2016), a presente pesquisa propõe-se a investigar a implementação dessa política em uma escola da rede pública municipal da cidade, a partir das percepções de seus agentes implementadores diretos. Para tanto, foi desenvolvido um estudo de caso na escola selecionada, privilegiando a realização de entrevistas como o principal instrumento de geração de dados. A próxima seção dedica-se à explicação do recorte de pesquisa realizado, e da seleção dos agentes entrevistados.

\section{2. \\ O recorte de pesquisa: a Escola Sigma e a seleção dos entrevistados}

A escolha da escola para a realização do estudo de caso atendeu a determinados critérios que estipulamos no início da pesquisa. Primeiramente, buscávamos uma escola que tivesse um número de matrículas superior a 900 alunos, sendo considerada uma escola de enorme porte, de acordo com a categorização feita por Lima (2016). Como mostra a autora, essas escolas concentraram o maior número de projetos de correção de fluxo ao longo da implementação da política em tela. Além disso, a escola idealmente apresentaria mais de uma etapa de ensino (a exemplo do primeiro e segundo segmentos do Ensino Fundamental), visto que esse é mais um fator que compete, ao lado de seu porte, para a maior complexidade de sua gestão administrativa e pedagógica (OLIVEIRA, 2015). Por fim, buscávamos uma escola que houvesse organizado turmas de correção de fluxo desde o primeiro ano em que a política foi implementada no município.

Com base nesses critérios, chegamos à Escola Sigma, nome fictício que atribuímos à escola em que realizamos um estudo de caso, localizada na $2^{\mathrm{a}}$ 
Coordenadoria Regional de Educação ${ }^{26}$, que cobre a zona sul e parte da zona norte da cidade. A escola selecionada se localiza na zona norte. De acordo com o Censo Escolar de 2015, a Escola Sigma contava com 110 funcionários e um total de 1320 alunos, distribuídos na Educação Infantil (pré-escola) e no Ensino Fundamental (anos iniciais e finais).

Para que pudéssemos saber quantas e quais foram as turmas de correção de fluxo organizadas na Escola Sigma a partir de 2010, fizemos uma análise exploratória dos dados do Censo Escolar de 2010 a 2014 ${ }^{27}$, referentes à escola estudada. Cabe destacar que, embora os projetos de correção de fluxo tenham sido implementados na rede pública municipal de ensino do Rio de Janeiro a partir de 2009, foram encontradas no Censo Escolar desse ano apenas 15 matrículas em turmas de correção de fluxo em todo o município. Como pontuado por Lima (2016), essas matrículas provavelmente configuram erro de registro das informações, uma vez que, por motivos operacionais, os projetos só começaram a ser implementados no final do primeiro semestre de 2009 - após o preenchimento do Censo Escolar, que ocorre na última semana de maio. Diante dessa situação, elegemos o ano de 2010 como o marco inicial de nossa análise.

Como apresentado por Lima (2016), houve diversas alterações nos desenhos dos projetos no período. Por conta desse aspecto dinâmico da política, para identificar as turmas que haviam sido organizadas na escola entre 2010 e 2014, trabalhamos com duas bases do Censo Escolar - base de turmas e de matrículas e com os documentos oficiais (portarias de matrículas, resoluções, quadro de enturmação de alunos), em que constavam os códigos correspondentes às turmas de projeto e sua finalidade. A base foi recortada ainda apenas para o contingente de alunos matriculados nesse período na Escola Sigma. Já os projetos desenvolvidos na escola em 2015 e 2016 (ano em que fizemos o estudo de caso) foram reconstruídos a partir das entrevistas realizadas nesta pesquisa. No quadro 1 a seguir, apresentamos as turmas de correção de fluxo organizadas na Escola Sigma entre 2010 e 2016 :

\footnotetext{
${ }^{26} \mathrm{~A}$ escolha pela $2^{\mathrm{a}} \mathrm{CRE}$ se deu por conta da maior proximidade em relação à universidade onde se localiza o grupo de pesquisa do qual a pesquisadora faz parte.

27 Agradecemos à Lima (2016) a organização dos dados do Censo Escolar de 2010 a 2014 referentes à escola estudada nesta pesquisa.
} 


\section{Quadro 1: Turmas de Projetos de Correção de Fluxo organizadas na Escola Sigma entre 2010 e 2016}

\begin{tabular}{|c|c|c|}
\hline \multirow{2}{*}{ Ano } & \multicolumn{2}{|c|}{ Turmas de projeto organizadas na Escola Sigma } \\
\hline & Nome & Número total de turmas \\
\hline 2010 & $\begin{array}{c}\text { Realfabetização } 1 \\
\text { Realfabetização } 2 \\
\text { Aceleração } 1 \\
\text { Aceleração } 1\end{array}$ & 4 turmas \\
\hline 2011 & $\begin{array}{l}\text { Aceleração } 1 \\
\text { Aceleração } 2 \\
\text { Aceleração } 2 \\
\text { Aceleração } 3\end{array}$ & 4 turmas \\
\hline 2012 & $\begin{array}{c}\text { Aceleração } 2 \mathrm{~A}^{28} \\
\text { Aceleração } 2 \\
\text { Aceleração } 2\end{array}$ & 3 turmas \\
\hline 2013 & $\begin{array}{c}\text { Realfabetização } 1 \\
\text { Realfabetização } 2 \\
\text { Aceleração 1 } \\
\text { Aceleração 2B }\end{array}$ & 4 turmas $^{29}$ \\
\hline 2014 & $\begin{array}{c}\text { Realfabetização } 1 \\
\text { Aceleração 2A } \\
\text { Aceleração 2A } \\
\text { Aceleração } 3 \\
\end{array}$ & 4 turmas \\
\hline 2015 & $\begin{array}{c}\text { Aceleração 1 } \\
\text { Aceleração 2B } \\
\text { Aceleração 2B } \\
\text { Aceleração 2A }\end{array}$ & 4 turmas \\
\hline 2016 & Aceleração 2B & 1 turma \\
\hline
\end{tabular}

Fonte: Elaboração da autora, com base nos dados do Censo Escolar de 2010 a 2014, nos documentos oficiais, e nas entrevistas realizadas na Escola Sigma em 2016.

Após essa incursão exploratória sobre os dados do Censo Escolar com vistas a identificar os projetos que foram desenvolvidos na escola estudada, passamos ao detalhamento de como foi feito o presente estudo de caso.

\footnotetext{
28 A nomenclatura das turmas de Aceleração 2 se mostrou bastante variável ao longo da implementação da política. Em 2010, quando foi introduzido na rede, era destinado aos alunos do $7^{\circ}$ e $8^{\circ}$ anos com distorção idade/série igual ou superior a dois anos, com vistas à aceleração da conclusão do Ensino Fundamental em 1 ano. Em 2011, passou a atender alunos do $6^{\circ}$ ano com defasagem de dois ou mais anos. A partir deste ano, o Acelera 2 passou a ter dois anos de duração, com vistas a acelerar o $6^{\circ}$ e $7^{\circ}$ no primeiro ano, e o $8^{\circ}$ e $9^{\circ}$ no segundo ano. Em 2012, portanto, essas turmas continuaram e permaneceram com esse nome, ao passo que novas turmas de Aceleração 2 foram iniciadas, as quais receberam a denominação de 2A. Em 2013, previa-se que sua continuação se chamaria $2 \mathrm{~B}$, mas a partir daí encontram-se registros diversos. Muitas vezes o primeiro ano do projeto passou a ser chamado simplesmente de Aceleração 2 e o segundo ano de Aceleração $2 A$. No entanto, optamos pela padronização da nomenclatura dessas turmas nesta pesquisa. Dessa forma, na escola investigada, a partir de 2012 chamamos o primeiro ano do projeto Aceleração 2 de Aceleração $2 A$ e o segundo ano, de Aceleração $2 B$.

${ }_{29}$ Em 2013, a escola organizou uma turma do projeto Nenhuma Criança a Menos, que foi desenvolvido pela própria SME e destinado aos alunos do $3^{\circ}$ e $4^{\circ}$ ano. No entanto, essas turmas não foram consideradas como correção de fluxo pela equipe de projetos da SME, razão pela qual não aprofundaremos uma discussão sobre elas nesta pesquisa.
} 
Como pode ser visto no quadro 1, havia apenas uma turma de correção de fluxo na Escola Sigma no ano de 2016: a turma de Aceleração $2 B$, que levaria à terminalidade do Ensino Fundamental naquele ano. Nossas visitas ocorreram ao longo dos meses de junho, julho e setembro de 2016 (visto que agosto foi o mês de recesso na escola por conta dos Jogos Olímpicos na cidade) e totalizaram 15 encontros. Nesse período, conseguimos entrevistar um total de 32 agentes, incluindo professores, gestores, agentes educadores e alunos inseridos em turmas regulares e turmas de correção de fluxo. No quadro a seguir, discriminamos os indivíduos entrevistados, a quem foram atribuídos nomes fíctícios que serão usados ao longo da análise nos próximos capítulos:

\section{Quadro 2: Sujeitos entrevistados na Escola Sigma em 2016 30}

\begin{tabular}{|c|c|c|}
\hline \multirow{6}{*}{ 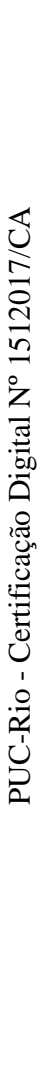 } & Função/descrição & Sujeitos entrevistados \\
\hline & Gestores & $\begin{array}{ll}\text { - } & \text { Diretora Geral } \\
\text { - } & \text { Diretora Adjunta } \\
\end{array}$ \\
\hline & Agentes Educadores & $\begin{array}{ll}\text { - } & \text { Agente Educadora } 1 \\
\text { - } & \text { Agente Educadora } 2 \\
\end{array}$ \\
\hline & Professores & $\begin{array}{ll}\text { - } & \text { Professora de turma de projeto dos anos finais (Sabrina) } \\
\text { - } & \text { Professora de Inglês de turma de projeto dos anos finais (Olívia) } \\
\text { - } & \text { Ex-professora de Inglês de turma de projeto nos anos finais } \\
\text { - } & \text { (Denise) } \\
\text { - } & \text { Ex-professor de turma de projeto dos anos finais (Roger) } \\
\text { - } & \text { Ex-professora de turma de projeto dos anos finais } 2 \text { (Isabel) } \\
\text { - } & \text { Ex-professora de turma de projeto dos anos finais } 3^{31} \text { (Marta) } \\
\text { - } & \text { Ex-professora de turma de projeto dos anos iniciais (Gisela) } \\
\text { - } & \text { Professora de Matemática de turmas regulares, dentre elas, uma } \\
\text { - } & \text { turma de } 6^{\circ} \text { ano cujos alunos eram, em sua maioria, advindos de } \\
\text { - } & \text { Professosor de Matemática de turmas regulares (Saulo) } \\
\text { - } & \text { Professora de Música de turmas regulares (Esther) } \\
\text { - } & \text { Professora generalista dos anos iniciais (Amanda) }\end{array}$ \\
\hline & $\begin{array}{l}\text { Alunos do } 8^{\circ} \text { ano } \\
\text { regular }\end{array}$ & $\begin{array}{l}\text { - } 3 \text { meninas } \\
\text { - } \quad 6 \text { meninos }\end{array}$ \\
\hline & $\begin{array}{l}\text { Alunos da turma } \mathrm{AC} \\
\qquad 2 \mathrm{~B}^{32}\end{array}$ & $\begin{array}{l}\text { - } 2 \text { meninas } \\
\text { - } \quad 4 \text { meninos }\end{array}$ \\
\hline
\end{tabular}

Fonte: Elaboração da autora

\footnotetext{
${ }^{30}$ Exceções na tabela: O professor Roger foi entrevistado em 2015, quando atuava como professor regente dessa turma. A entrevista realizada em 2015 foi conduzida por outra pesquisadora, membro do grupo de pesquisa do qual faço parte, e acompanhada por mim.

${ }^{31}$ A pedido dessa professora, sua entrevista não foi gravada. Seu relato foi registrado por meio de anotações no diário de campo.

${ }^{32}$ Havia uma exceção a essa descrição: um dos alunos entrevistados era egresso desse mesmo projeto (AC 2B), que tinha concluído no ano anterior à entrevista (2015). O aluno estava visitando a escola no dia em que os demais alunos foram entrevistados, e aceitou gravar entrevista conosco.
} 
As entrevistas tiveram duração média aproximada de 40 minutos, no caso de professores e gestores, e de 10 minutos - no caso dos alunos, todas elas tendo sido realizadas na própria escola. Após transcritas, as 32 entrevistas foram analisadas com o auxílio do software Atlas T.I, por meio do qual foram codificadas e reorganizadas.

Conforme pode ser observado no quadro, conseguimos entrevistar apenas duas professoras generalistas que trabalham nos anos iniciais, dentre elas, uma que havia sido regente de turmas de projeto no primeiro segmento. Os demais professores são especialistas dos anos finais, dentre os quais 7 haviam trabalhado com turmas de projeto neste segmento. Dessa forma, nossa análise será centrada nos projetos que se desenvolveram nos anos finais do Ensino Fundamental, desenvolvidos em parceira com a Fundação Roberto Marinho (Aceleração 2 e Aceleração 3).

Como foi apresentado no capítulo anterior, na seção 3.3, buscamos um enfoque sobre os agentes implementadores da política em tela no nível da escola, e sobre os valores que orientam suas práticas discricionárias. O olhar sobre essa cadeia de atores e sobre seus valores se dá a partir das considerações de Lotta (2014), que sugerem a necessidade da incorporação desses dois focos de atenção às análises no campo. Esse enfoque também se justifica a partir de uma perspectiva que concebe o processo de implementação como uma interação entre esses atores nos ambientes organizacionais e relacionais de que fazem parte.

Cabe destacar que não foi possível realizar uma observação participante ao longo do período de implementação da política, de forma a captar diretamente como se dava essa interação entre atores, em decorrência do pouco tempo de que dispúnhamos para o trabalho de campo. Dessa forma, o enfoque sobre os discursos dos agentes construídos na situação de entrevista busca proporcionar uma tentativa de reconstrução das práticas efetivamente ocorridas durante o processo de implementação da política em estudo, diante da impossibilidade de acesso direto a elas. Reconhecendo que a focalização dessas práticas é imprescindível ao estudo da escola, Licínio Lima (2011) afirma também que aproximações ao estudo da ação organizacional que não envolvam sua observação direta e sincrônica são igualmente possíveis e, por vezes, até mesmo desejáveis. Nesse sentido, a condução de entrevistas pode configurar um instrumento útil para 
a geração de narrativas que recuperem e recriem, sempre na ótica dos atores, o universo da organização e as práticas empreendidas dentro dele.

Além de possibilitar uma aproximação dessas ações concretas, as entrevistas são "fundamentais quando se precisa/deseja mapear práticas, crenças, valores e sistemas classificatórios de universos sociais específicos" permeados por conflitos e contradições por vezes implícitos (DUARTE, 2004, p.215). Dessa forma, configuraram como principal instrumento de geração de dados na presente pesquisa por permitirem tanto uma aproximação às práticas de implementação ocorridas na escola, quanto a compreensão de quais ideias e valores influenciaram sua realização.

Para melhor compreender esse material linguístico gerado em campo, lançamos mão da abordagem hermenêutica-dialética proposta em Minayo (2010). A próxima seção se dedica, portanto, a uma breve apresentação dessa abordagem de análise do material qualitativo. Após essa contextualização, passamos à última seção deste capítulo (4.4), em que buscamos compreender o contexto organizacional em que foi implementada a política em tela, por meio da ótica dos agentes implementadores.

\section{3. \\ A análise do material qualitativo: uma abordagem hermenêutica- dialética}

$\mathrm{O}$ ato do entendimento, mais do que um desvendamento da verdade do objeto, é a revelação do que "o outro" (o "tu") coloca como verdade (MINAYO, 2010, p. 333)

Como apontado por Dubar (2004), a forma como os pesquisadores sociais escolhem pensar os indivíduos pesquisados se relaciona diretamente com sua concepção sobre linguagem, ou seja, com o modo como tratam as palavras desses indivíduos. Em se tratando de uma pesquisa qualitativa como esta, que lida diretamente com um material linguístico gerado por meio de entrevistas, cabe um cuidado especial com a fase de análise dos dados e com a forma de tratamento dessas palavras e desses indivíduos.

Nesse sentido, buscando evitar a "ilusão da transparência" (BOURDIEU et al., 1968), compreendemos que o discurso dos entrevistados não se constitui em um simples reflexo da realidade, de forma que o sentido investigado pudesse ser diretamente apreendido de suas falas. Partir desse princípio poderia levar o ato de 
pesquisa a uma reprodução do senso comum e/ou de uma verdade parcial, aquela construída pelo entrevistado dentro das determinações de um contexto interacional e social mais amplo. Por outro lado, tampouco apostamos em uma perspectiva exageradamente estruturalista, que compreenda a linguagem desses agentes como completa construção da realidade a partir de um sentido predeterminado, que não pertence a eles, mas ao sistema do qual fazem parte. Essa segunda perspectiva poderia arriscar desconsiderar por completo os motivos e as próprias lógicas narradas pelos indivíduos entrevistados, como se suas percepções estivessem completamente dissociadas de uma realidade externa, material, fora de seu discurso.

Com base nesses pressupostos, esta seção apresenta um breve resumo da abordagem que buscamos empregar na fase de análise do material qualitativo, com vistas a aproximar determinação e construção, compreensão e crítica na análise dos textos gerados. Trata-se da abordagem hermenêutica-dialética apresentada em Minayo (2010), que busca conciliar as contribuições de autores como Gadamer (1999), Habermas (1987) e Stein (1987) na busca por um instrumental de análise que articule "a subjetivação do objeto e a objetivação do sujeito". Para tanto, começamos por um resumo das principais ideias e categorias da hermenêutica e da dialética separadamente, finalizando com a proposta de articulação entre as duas no presente trabalho.

Como pontuado por Minayo (2010), a principal categoria metodológica na qual se funda a hermenêutica é a proposta de compreensão durante o processo investigativo. Trata-se, portanto, de um movimento de empatia, em que o pesquisador busca colocar-se no lugar do outro (o pesquisado), de forma a compreender o sentido que busca expressar, a apreensão da realidade a partir de sua posição. É possível, nesse ponto, traçar um paralelo com a sociologia compreensiva weberiana, em que se busca o sentido que orienta a ação social dos indivíduos. Nesse processo, observam-se dois movimentos dialéticos: o mover-se entre o todo e as partes, e entre a liberdade e a necessidade.

Schleiermarcher (2000) pontua que a principal característica da compreensão é o fato de que o sentido do particular (da parte) resulta do contexto (do todo). Esta é a razão pela qual, na presente pesquisa, busca-se inicialmente compreender o contexto institucional e organizacional no qual atuam os agentes, para que se possa melhor analisar suas práticas particulares. No entanto, como 
assinala Gadamer (1999, p. 297), citado por Minayo (2010), “o todo, a partir do qual se deve compreender o individual, não pode ser dado antes do individual". De fato, a seção anterior que buscou a compreensão do contexto organizacional da Escola Sigma, bem como a seção seguinte que busca compreendê-lo por meio da percepção dos agentes entrevistados, constroem esse "todo" a partir de diversas "partes": dados do Censo Escolar e dados das entrevistas com diversos agentes. Dessa forma, como continua Gadamer (idem), “o compreender é sempre mover-se nesse círculo, e, portanto, é essencial o constante retorno do todo às partes e viceversa". Diante dessa perspectiva, buscou-se articular constantemente as percepções e as ações dos entrevistados ao todo que os envolve (ao contexto em que atuam), de forma a melhor compreendê-las, bem como mostrar de que forma esse contexto mais amplo é também construído por suas crenças e práticas.

Pode-se dizer que um movimento semelhante ocorre entre as categorias "liberdade" e "necessidade", diretamente relacionadas à escolha pelos termos "atores" e "agentes" quando da definição dos indivíduos entrevistados. Como sinaliza Minayo (2010), não se pode dizer que há determinação total dos acontecimentos históricos, visto que são produzidos por pessoas que dispõem de liberdade, não sendo meros efeitos de uma estrutura mecânica. Contudo, juntamente à liberdade humana caminha o conceito de necessidade, que diz respeito ao que "já se formou, que não pode ser desfeito e passou a ser a base para toda atividade emergente do sujeito individual e coletivo" (p. 331).

Dessa forma, pode-se dizer que a liberdade de escolha opera dentro de um contexto de possibilidades, visto que esse "pano de fundo" anterior à atividade livre restringe a ação àquilo que é possível. Esse contexto de possibilidades (a necessidade), por sua vez, é resultante da liberdade de outros atores ao longo da história e, justamente por isso não é estável e finito, estando sempre aberto a possibilidades de mudança. Considerando, portanto, que a "necessidade procede da liberdade, e a liberdade precisa contar com ela" (ibidem, p. 332), a presente pesquisa propõe um uso intercambiável das nomenclaturas "agente" e "ator" para tratar dos entrevistados. Essa escolha se ancora, na perspectiva dialética que prevê a capacidade de atuação dos indivíduos, ainda que constrangida pelas possibilidades de seu contexto, o qual também é construído parcialmente por essas ações. Nesse sentido, pode-se dizer que a compreensão desses indivíduos aqui 
referenciados ora como "agentes" e ora como "atores" se aproxima da definição conferida por Dubar (2004) ao "autor", cujos relatos comumente

misturam coerção e decisão, determinações (sociais, escolares, espaciais etc.) e estratégias (profissionais, afetivas etc.), atribuições (estigmatizações, rotulações etc.) e reivindicações (estabilidade, reconhecimento etc.). Definir o indivíduo como autor não é, portanto, atribuir-lhe uma autonomia todo-poderosa, mas fazer dele o produtor-enunciador de um discurso que, através das coerções do relato, induz e permite uma articulação entre determinações sociais e construção pessoal, socialização e estratégias. (DUBAR, 2004, p. 65)

Como categoria básica das ciências compreensivas, Minayo (2010) apresenta o senso comum, definido por Gadamer como uma espécie de saber que incorpora uma um valor prático-moral: um saber que se ancora em vivências, em vez de deliberações racionais, buscando aquilo que é plausível, prático, e que se orienta para o "verdadeiro" e para o "correto". O próprio conceito de vivência constitui outra ideia importante para a análise hermenêutica proposta por esse autor, que a caracteriza como uma apreensão imediata de algo real. Trata-se, portanto, de uma experimentação direta do real, diferente da compreensão científica, por exemplo, que se dá de forma mediada e mais distanciada.

Ambas as categorias assumem relevância significativa na presente pesquisa, visto que o trabalho na linha de frente é, em grande parte, orientado com base em um senso prático-moral advindo da vivência desses agentes. Como pontuado por Maynard-Moody e Musheno (2003), os agentes da linha de frente não são idealistas que operam com conceitos abstratos e filosóficos de justiça, equidade e moralidade. A forma como se apresentam em suas narrativas e os eventos que contam os constroem como pragmáticos. São pessoas que orientam suas ações com base em saberes e julgamentos práticos advindos da experiência de trabalho em um contexto que lida com a imprevisibilidade e que requer, portanto, capacidade de improvisação e ajuste de expectativas. Esses trabalhadores não são aqueles que pesquisam e teorizam sobre os necessitados, os excluídos e os marginalizados pela sociedade, mas que lidam diretamente com eles. Quando percebem um conflito entre a regras e a necessidade dos indivíduos, é sua percepção de justiça - aquilo que consideram certo - o principal fator que orienta suas práticas concretas. Dessa forma, para esses agentes:

O conceito de justiça tem pouco a ver com a norma burocrática de tratar a todos da mesma forma ou até mesmo de implementar regularmente as leis. Para nossos narradores, equidade e justiça significam responder aos cidadãos-cliente com base em seu valor/merecimento percebido. Mais do que agentes da lei, os 
trabalhadores do nível de rua - no nosso estudo, policiais, professores, e conselheiros de reabilitação vocacional - são produtores de valores e caráter que incorporam as noções correntes de valor moral e adesão produtiva na sociedade. (MAYNARD-MOODY e MUSHENO, 2003, p. 94 - grifos da autora) ${ }^{33}$

Assim como ocorre com a discricionariedade, esse senso comum pragmático e moral, que muitas vezes orienta o exercício discricionário, pode ser considerado positivo, negativo, ou oscilar entre um polo e outro. Se, em sua face positiva, pode ser considerado um "gênio da vida prática" que permite o ajustamento em relação à realidade, em sua face negativa pode ser considerado um julgamento leigo, preconceituoso, ou uma falsa consciência de uma realidade mais complexa.

Dessa forma, a proposta de uma hermenêutica busca a capacidade de compreensão, ou seja, de interpretação, relação e extração de conclusões em diversas direções. A própria necessidade de compreensão indica que há um transtorno no entendimento, ou seja, que linguagem não é transparente e que não apenas reflete a realidade tal como ela é, sendo também uma forma de construí-la e interpretá-la. Nesse sentido, é importante ressaltar que não tomamos as falas dos agentes entrevistados nesta pesquisa como mero reflexos de uma realidade externa, mas também como uma forma de construção de sua realidade e do sentido que atribuem a ela.

Ao passo que a hermenêutica propõe o exercício da familiaridade e da empatia com o sujeito entrevistado, de forma a compreender o sentido que este constrói e suas razões para tal, a dialética se mostra como o exercício contrário: o estranhamento e a crítica. Fazendo menção a Habermas (1987), Minayo (2010) apresenta a crítica que o autor faz ao campo compreensivista, que focaliza um espaço restrito de comunicação (a vida cotidiana) como se esse universo representasse todo o processo sociohistórico e cultural. Nesse sentido, na presente pesquisa, busca-se exercitar um afastamento crítico em relação às falas dos agentes de nível de rua, no caso, os professores e gestores da escola. Esses indivíduos muitas vezes atribuem à sua realidade da linha de frente - o "chão da escola"- a totalidade da vida real, de forma a tornar mais legítimos seus valores,

\footnotetext{
33"Fairness has little to do with the bureaucratic norm of treating everyone the same or even fairly implementing laws and regulations. To our storytellers, fairness and justice mean responding to citizen-clients based on their perceived worth. More than enforcers of law, street-level workers in our study, cops, teachers, and vocational rehabilitation counselors - are producers of values and character that embody mainstream notions of moral worth and productive membership in society." (MAYNARD-MOODY e MUSHENO, 2003, p.94)
} 
crenças e juízos, visto que são calcados nessa experiência concreta da própria "realidade" em si, da forma como a percebem.

No entanto, como menciona Habermas (1987), o contexto da tradição, ou da vida prática, comum, não é apenas espaço de verdade, sendo também atravessado por interesses e pela violência. Assim, a linguagem que representa esse mundo e esse espaço seria igualmente marcada por esses interesses em disputa e pela própria violência:

Linguagem é também meio de dominação e de poder social. Serve às relações de violência organizada. Na medida em que as legitimações não manifestam a relação de violência, cuja institucionalização possibilita, e na medida em que isso só se expressa em legitimações, a linguagem também é ideológica. (HABERMAS, 1987, p. 21, apud MINAYO, 2010, p. 346)

Nesse sentido, cumpre atentar para uma espécie de violência discursiva recorrente nas falas dos entrevistados que diz respeito à rotulação do aluno multirrepetente como "aquele que não quer nada", reduzindo sua identidade e a razão de seu fracasso a uma deficiência moral. Como pontua Habermas (1987), na medida em que essa violência simbólica é institucionalizada no espaço escolar, ela se torna legítima aos olhos de seus membros, incluindo os próprios alunos multirrepetentes, que assumem esse discurso como a razão para seu fracasso. No entanto, o que permanece ocultado nessa relação de violência é a possibilidade de que a própria escola também fracasse em ensinar esse aluno, uma vez que, sem se considerar responsável por seu processo de ensino-aprendizagem, o culpabiliza unilateralmente pela sua situação. Dessa forma, o discurso da escola constrói a "falta de vontade" do aluno como causa do seu não-aprendizado, em vez de percebê-la como um possível efeito desse fracasso. Essa violência simbólica que ocorre no espaço escolar e que, ao ser ocultada, assume um caráter de legitimidade, é central na obra de Bourdieu.

O exercício dialético, portanto, torna fundamental a realização de críticas às ideias expostas nos produtos sociais e históricos, sejam eles discursos, organizações ou instituições. Dessa forma, concebe a linguagem e suas práticas também como território de disputas, de contradição, de conformidade e resistência.

Com base nessas breves considerações, pode-se dizer que uma abordagem hermenêutica-dialética propõe o movimento entre o familiar e o estranho. Ao passo que a hermenêutica enfatiza a compreensão do sentido entendido pelo 
agente, e propõe um exercício empático quanto a suas interpretações e suas razões com base na vivência, a dialética introduz a dimensão conflitiva e contraditória da realidade social, realizando uma crítica ao que é dito, bem como àquilo que permite ser lido. Nas palavras de Minayo (2010, p. 343), “o casamento das duas abordagens é fecundo na condução do processo ao mesmo tempo compreensivo e crítico de estudo da realidade social". Desse modo, a presente pesquisa busca tanto uma compreensão das percepções dos agentes e do sentido que constroem para suas ações dentro de um contexto desafiador, quanto uma crítica a eventuais crenças e preconceitos em que se baseiam essas percepções, que têm efeitos concretos no exercício político de sua discricionariedade e, consequentemente, nas relações que se (re)produzem na escola.

Na próxima seção, passamos às percepções desses agentes sobre a Escola Sigma, descrita na seção anterior. Uma vez que essas percepções fazem parte do material qualitativo gerado na pesquisa, já na próxima seção buscamos fazer uso das contribuições da abordagem hermenêutica-dialética para analisá-las.

\section{4.}

\section{A Escola Sigma na percepção dos agentes entrevistados}

A cada ano que passa, vai piorando. Mas eu adorava essa escola. Essa escola sempre foi a padrão do [nome do bairro]. Meus sobrinhos, que já estão com 40 anos, estudaram aqui. (Professora Isabel)

Um dos primeiros elementos que se mostra recorrente na percepção de diversos agentes escolares entrevistados é a sensação de "queda de nível" pela qual vem passando a Escola Sigma a partir da chegada de um novo público, cujo perfil é diferente daquele que frequentava a escola. Anteriormente, os alunos eram advindos das camadas médias e médias-baixas - eram, por exemplo, filhos de porteiros, de taxistas, de açougueiros, do comércio em geral - e a percepção predominante é de que seus pais se preocupavam com sua formação e participavam de sua vida escolar. Atualmente, os agentes identificam que, para além das camadas médias mais empobrecidas da região, muitos alunos vêm das comunidades/favelas do entorno. Nesse sentido, ressaltam que não há problemas de violência interna como há em outras escolas por conta do atendimento a alunos que moram em comunidades dominadas por facções distintas, o que julgam um ponto positivo na Escola Sigma. No entanto, consideram que as famílias da 
maioria dos alunos que são moradores de comunidades do entorno não têm a mesma visão que tinham os pais dos alunos que frequentavam a escola anteriormente. Essas famílias são caracterizadas como desestruturadas e envolvidas em problemas como uso de drogas, gravidez na adolescência, violência urbana, o que levaria a uma baixa participação na vida escolar dos filhos.

Essa sensação de queda de nível acompanha a percepção dos agentes quanto ao desempenho e comportamento dos alunos: anteriormente, diziam receber alunos interessados, que pediam dicas de estudo para as provas de colégios públicos federais, e que tinham respeito pelos professores. Ao passo que os alunos de antes advindos das camadas médias eram identificados como interessados, dedicados e respeitosos, os alunos de hoje, vindos principalmente das comunidades do entorno, têm o desinteresse, a falta de vontade de estudar e a indisciplina como principais características, na percepção de muitos agentes. Essa condição, por sua vez, é atribuída à falta de interesse dos responsáveis e a uma cultura do "pode tudo" hoje em dia, que impede que se tomem medidas mais duras para garantir a disciplina desses estudantes.

Já nesse ponto, é possível estabelecer um paralelo entre essas percepções e as relações entre expansão e estratificação escolar discutidas ao longo do capítulo 2. Pode-se dizer que a Escola Sigma constitui um caso típico em que a ampliação da escolarização trouxe a incorporação de outros setores ao sistema escolar que, não sendo herdeiros de uma cultura letrada ou, principalmente, de um ethos de ascensão social pela escola, são percebidos como a origem de uma crise e queda de nível desse sistema. A importância relativamente maior do ethos quando comparado à herança de uma cultura escolar propriamente dita fica clara quando os alunos anteriormente recebidos pela Escola Sigma são descritos como pertencentes às camadas médias (filhos de comerciantes da região) e não exatamente advindos de grupos tradicionalmente letrados. Contudo, eram alunos cujos pais pareciam valorizar mais sua trajetória escolar, e que respondiam a esse interesse com sua dedicação à escola. A partir de uma leitura bourdieusiana, seria possível dizer que esses alunos recém-ingressos, por não serem herdeiros de uma tradição escolar, tampouco de uma boa vontade cultural típica das camadas médias, são aqueles que se refugiam em uma atitude negativa em relação à escola. Essa postura, por sua vez, é percebida pelos educadores como modos de 
desobediência e desordem anteriormente desconhecidos, o que faz com se atribua a esses alunos o rótulo de "indisciplinados", para além de suas supostas falhas morais (uma falta de vontade de estudar).

O relato dos agentes constrói, portanto, a qualidade da escola apenas como uma função do público atendido, e não de suas características internas, como a qualidade profissional dos agentes, por exemplo. Mais ainda, a escola torna-se uma função de seus alunos que, por sua vez, são apresentados como função de suas famílias e do meio em que vivem. Dessa forma, a escola era outra quando os alunos que recebiam eram outros, visto que suas famílias eram outras - ambos julgados de acordo com um ethos de boa vontade e interesse em relação à trajetória escolar. Sua “queda de nível” teria sido causada, portanto, pelas novas camadas recém-ingressas, e não por conta de uma eventual dificuldade da organização em atender a esses novos alunos e às suas necessidades de ensinoaprendizagem.

É importante ressaltar que a correlação entre a condição socioeconômica do alunado e os resultados escolares encontra respaldo em diversos achados em Sociologia da Educação. No entanto, estudos em eficácia escolar apontam que o estabelecimento de ensino - a organização escolar e seu próprio ethos - também constitui importante variável explicativa desses resultados (RUTTER et al, 1979; ALVES e FRANCO, 2008). Dessa forma, analisar o modo como os atores (re)significam esse espaço onde atuam torna-se essencial para compreender as práticas concretas empreendidas durante a implementação dos projetos de correção de fluxo na escola, bem como a ação organizacional como um todo.

Como pontuado por Costa e Castanheira (2015), a análise da escola enquanto uma organização exige o reconhecimento de sua principal especificidade em relação às demais organizações: "a singularidade da sua missão, que é uma missão essencialmente pedagógica e educativa (dirigida a crianças e jovens em desenvolvimento)" (p. 26). O caráter fundamentalmente pedagógico das organizações escolares, no entanto, não pressupõe automaticamente uma coesão dos diversos agentes que dela fazem parte em torno de um mesmo objetivo e foco. Em se tratando de sistemas debilmente articulados e anarquias organizadas (LIMA, 2011), conflitos de interesses, disputas por significados e poder, e falta de clareza de objetivos e tecnologias não são raros no seu interior. Nesse sentido, observa-se uma primeira heterogeneidade de percepções dentro da Escola Sigma 
quanto ao principal objetivo da organização - fator diretamente relacionado à gestão e liderança, nas quais estão imbricados conceitos como visão, missão e valores, e a mobilização para seu alcance.

Um elemento que se destaca na percepção dos agentes entrevistados diz respeito às novas demandas que a Escola Sigma (assim como outras escolas públicas) passa a assumir, e ao impacto dessas demandas na missão pedagógica da escola. Nas palavras de Amanda, professora generalista dos anos iniciais:

Olha, eu acho que a sociedade... os pais hoje estão muito envolvidos com a questão de trabalho, com a necessidade financeira, e começou acho que uma visão um pouco distorcida de que a escola não é só um local de aprendizagem. A escola passa a ser, principalmente a escola pública, passa a ser o local de alimentação, passa a ser o local de tomar conta, passa a ter outras funções que não a aprendizagem. Então, assim, quando você foca em muita coisa, você perde o foco. (Professora Amanda)

O relato dessa professora ecoa as constatações de Costa Ribeiro (1991) discutidas também no capítulo 2, que dizem respeito à ausência de uma autêntica e autossuficiente função educadora da escola. Para o autor, essa função teria estado ausente no país mesmo quando a escola era dedicada somente às elites. Nessa época, o professor atuava mais como um preceptor da educação orientada pela família do que como mentor de um processo de ensino-aprendizagem autônomo. Esse mesmo modelo de escola teria sido, então, estendido a setores que não compartilhavam dessa experiência e histórico familiar, e para quem esse modelo não poderia funcionar. Dessa forma, a ausência dessa função educadora autossuficiente teria se tornado ainda mais evidente, fazendo com que a escola praticamente perdesse seu sentido como local de ensino-aprendizagem aos olhos dos agentes escolares. Outros papéis passavam a ser assumidos (creche, restaurante, "depósito de crianças"), nos quais estaria implicada uma função mais socializadora e assistencialista do que propriamente de ensino e aprendizagem.

Ao conceber esse enfraquecimento do sentido como um fenômeno mais recente (“os pais hoje”; “começou uma visão um pouco distorcida”), a percepção da professora Amanda reforça a perspectiva de Costa Ribeiro (1991) quanto à maior evidência que tem assumido essa ausência de uma função educadora por parte da escola. Mais do que considerar esse esvaziamento de sentido e o acúmulo de papéis como algo recente, a professora os percebe principalmente na escola pública, e deixa implícito que há uma questão familiar implicada nesse processo (“os pais hoje estão muito envolvidos com a questão de trabalho"). Dessa forma, 
aproxima-se mais uma vez da perspectiva de Costa Ribeiro (1991), no sentido de que uma possível razão para a maior evidência desse fenômeno seria a expansão de um modelo de escolarização a um público cujo histórico familiar não é o mesmo daquele apresentado pelos alunos da escola pública anteriormente.

A relação entre a fala da professora entrevistada e as constatações de Costa Ribeiro (1991) sugere que o acúmulo de funções por parte da escola a partir de sua maior democratização não é uma característica típica somente da organização estudada. Como visto ao longo da revisão de literatura, trata-se de um fenômeno institucional mais amplo sobre o qual se debruçam diversas teorias explicativas, a exemplo da bourdieusiana. Nesse sentido, usando conceitos da hermenêutica, pode-se compreender esses fenômenos como uma espécie de "necessidade", um "contexto de possibilidades" ou, ainda, um pano de fundo relativo a um discurso que já se formou e que passou a ser a "base" para a atividade livre dos indivíduos dentro dessa organização.

No entanto, para além disso, essas percepções têm implicações diretas sobre a forma como a Escola Sigma enquanto organização se estrutura diante dessa realidade - o que estabelece como suas prioridades, qual acredita ser sua função, e quem acredita merecer determinado tratamento. Movimentando-se dialeticamente da necessidade à liberdade, pode-se dizer que a constatação de que a escola vem tendo sua função educadora esvaziada com a mudança de público-alvo acaba sendo fortalecida e ganhando uma dimensão normativa na percepção de outros agentes, que reformulam a missão da escola como instituição socializadora:

Eu acho que a missão de qualquer escola é preparar pra vida, né. Preparar aí para as maiores dificuldades. Ele [o aluno] não sabe obedecer a uma ordem, ele não sabe seguir regras, então isso é preparar pra vida. A parte curricular é... também anda junto, mas não é a única parte importante. Eles precisam de ser educados para a vida. Socialmente, né, educar socialmente também. (Diretora Geral)

Na percepção da diretora da Escola Sigma, exemplificada no trecho acima, destaca-se a dimensão socializadora da educação escolar como uma espécie de instituição disciplinadora e civilizatória. Nesse sentido, a preparação para a vida em sociedade corresponderia à capacidade do indivíduo de obedecer a ordens e seguir regras, habilidade tão importante quanto (ou mais importante do que) o aprendizado curricular propriamente dito. Trata-se de uma concepção aliada com a percepção hegemônica que se tem sobre os alunos da Escola Sigma. Esses alunos, diferentemente daqueles de antigamente, são descritos como crianças 
indisciplinadas e sem uma família presente, que "não vão estar prontas pra sociedade, pro trabalho, pra obedecer uma ordem de um patrão".

Nesse ponto, seu discurso ecoa em certa medida a perspectiva de Collins (1971) mencionada no capítulo 2, segundo o qual a principal função da escola não seria a transmissão de conhecimentos técnicos, mas o ensino de culturas de status a setores mais privilegiados da sociedade. Para outras camadas, tornava-se importante a aquisição de certo apreço e respeito por esses valores, ainda que não os dominassem, para que pudessem ocupar outras posições nesse mesmo mercado. Essa proposta de um ensino dual, como também já visto, é considerada um elemento característico do desenvolvimento histórico do sistema educacional brasileiro - uma instrução primária civilizatória e uma educação secundária para a elite ilustrada. Contudo, já passando a uma perspectiva reprodutivista, a democratização dessa etapa teria mantido a própria dualidade de ensino, visto que as crianças de origens sociais diferentes continuavam sendo treinadas para absorver valores distintos, compatíveis com sua posição de classe. Como pontuam Bowles e Gintis (2000), a escolarização impactava as normas e preferências individuais, tornando o futuro trabalhador mais atraente ao seu empregador ao amenizar problemas relacionados, por exemplo, à disciplina.

Dessa forma, pode-se dizer que esse tipo de percepção pode acabar por reproduzir e reforçar um discurso segundo o qual a principal função da escola para as camadas populares seria a inculcação de valores como o respeito e a deferência à hierarquia, que garantissem uma inserção mais obediente na sociedade. Consequentemente, o compromisso com o ensino-aprendizagem desses alunos fica secundarizado, contribuindo para a reprodução de sua condição social. Essa perspectiva também é trazida por Maynard-Moody e Musheno (2003, p. 74), que reconhecem nas narrativas dos professores, principalmente aqueles que trabalham em bairros menos privilegiados, o objetivo comum de inculcar nos alunos valores característicos da classe média, como disciplina, responsabilidade, esforço, e gratificação a posteriori. Aqueles que aderem a esses ideais são recompensados pela comunidade escolar, e aqueles que os rejeitam podem ser considerados problemáticos, e acabarem isolados ou punidos.

Essa relativização da função pedagógica, em detrimento de outras prioridades adotadas pela organização, também aparece no relato de agentes que atribuem à formação do cidadão o principal foco da escola: 
A gente tá muito preocupado com a questão da aprendizagem, mas muito mais com a formação de um cidadão. Porque aqui dentro da escola a gente tem problemas que são generalizados. De violência, de roubo, de bullying [...]. Obviamente a gente tá preocupado com a aprendizagem, com o conteúdo e tal, somos cobrados por isso, mas a gente quer que no final das contas esse aluno saia daqui melhor. Uma pessoa melhor, um cidadão que sabe conviver em sociedade, que respeite o próximo. (Professora Esther)

O discurso da professora tem eco, mais uma vez, na percepção de que questões relacionadas ao comportamento discente influenciam diretamente a ressignificação da missão escolar. É possível compreender, dentro do contexto de interação, que a professora destaca a formação cidadã como uma educação mais integral do indivíduo, em oposição a uma instrução mais conteudista, que privilegiasse apenas o domínio de conteúdos escolares. Chama atenção, contudo, que em diversos relatos a formação cidadã é construída discursivamente de forma desconectada da questão da aprendizagem, como objetivos separados e não interrelacionados. Enunciados como "a gente tá muito preocupado com a questão da aprendizagem, mas muito mais com a formação de um cidadão" separam esses dois objetos, permitindo, portanto, que venham a ser enfatizados de forma exclusiva. No entanto, como pontua Sampaio (2000, p. 62), a formação cidadã e a aprendizagem estão intimamente relacionadas naquilo que seria o principal objetivo da escola enquanto instituição: "essência de sua atividade-fim, que é, pela via do conhecimento, a formação das crianças e jovens que frequentam suas dependências todos os dias".

Além disso, como será mais desenvolvido no capítulo seguinte, cabe refletir sobre a estreita relação entre (dificuldade de) aprendizagem e os problemas de comportamento que vêm ganhando progressiva importância na Escola Sigma. Embora esses dois conceitos apareçam bastante discriminados na perspectiva de diversos agentes, outras percepções emergem no sentido de sugerir uma causalidade entre eles, como a fala de uma professora dos anos iniciais: "Até porque eu não sei qual é a ordem, se ela [a criança] é agitada e, por isso, não conseguiu aprender, ou se ela se tornou agitada porque ela não consegue acompanhar".

O enfraquecimento da missão propriamente pedagógica da escola, constatado no plano simbólico das crenças dos atores, é também influenciado por limitações estruturais que caracterizam a Escola Sigma. Nesse sentido, é significativo o relato da Diretora Geral, segundo a qual "nenhuma pessoa dá conta 
realmente de fazer um trabalho bom" em uma escola com 1400 alunos, da educação infantil até o $9^{\circ}$ ano, e que não dispõe de um coordenador pedagógico. De acordo com a diretora, a maioria dos professores rejeitam o convite para serem coordenadores, visto que "não existe quem dê conta de coordenação para 10 turmas de Educação Infantil, 20 turmas de Anos Iniciais, mais 20 do Ginásio, mais os projetos". As condições de trabalho da gestão, já prenunciadas na seção 4.2, apontam para enormes desafios que inevitavelmente impactam a percepção da equipe gestora quanto aos limites e possibilidades de sua atuação.

Como pontuado em Paes de Carvalho et al (2014), a gestão escolar depende de insumos relativos à infraestrutura, ao quadro de pessoal, aos materiais pedagógicos e às dependências físicas, para seu bom desenvolvimento. Contudo, esses recursos não se encontram igualmente distribuídos entre as escolas, não sendo raras, ainda, situações de escassez, sobretudo no que diz respeito ao quadro de funcionários (administrativos e pedagógicos). Consequentemente, observa-se uma sobrecarga de trabalho burocrático por parte da gestão escolar, intensificada com o aumento de programas e projetos educacionais na última década. Isso tem dificultado o envolvimento dos diretores com uma liderança pedagógica, apontada em diversas pesquisas como importante fator de eficácia escolar (SAMMONS, 2008; ALVES e FRANCO, 2008, entre outros).

Esse parece ser o caso da Escola Sigma, que conta com mais de 1000 alunos distribuídos entre diferentes etapas de ensino, e uma equipe administrativa limitada para dar conta de todo trabalho exigido. A percepção da organização com uma "escola enorme e muito complexa" foi unânime em todas as entrevistas, que ressaltaram também a falta de recursos materiais e humanos com que se deparam. Embora reconheçam que a falta desses instrumentos seja um problema da rede municipal no geral, os professores chamam atenção para certa desigualdade na distribuição desses recursos:

Eu acho que é uma escola muito grande, muito complexa. É uma escola diferenciada por conta disso, diferenciada a nível de trabalho. Não vejo ela diferenciada a nível de visão do município, a nível de verba, a nível de atendimento das suas necessidades. (Professora Amanda)

Mais ainda do que a falta de recursos materiais, é a falta de recursos humanos que aparece como a principal carência da Escola Sigma na percepção dos agentes entrevistados. Nesse sentido, a ausência de um coordenador pedagógico que faça a articulação entre o trabalho dos professores das diferentes 
etapas de ensino, e até mesmo dentro do próprio segmento, é apontada como a mais grave.

Como também pontuado por Paes de Carvalho et al (2014), cabe destacar que esse quadro de pessoal deficitário é uma dimensão sobre a qual a gestão tem ação limitada, diante das normas centrais que regulam a lotação de funcionários e as verbas dirigidas para cada finalidade. Nesse sentido, não somente a equipe gestora, mas também alguns professores entrevistados mencionaram a falta de incentivo salarial à altura do que demanda o cargo de coordenador pedagógico em uma escola daquela magnitude - caracterizado como um "abacaxi que ninguém quer pegar”. Essa característica estrutural mais ampla, sobre a qual os agentes da linha de frente não têm gerência direta, contribui mais ainda para a desarticulação docente dentro da organização e, consequentemente, para a dificuldade em se construir um clima acadêmico e um ambiente próprio para a aprendizagem. Nas palavras dos professores, eles acabam agindo "cada um por si", o que ratifica a percepção de que em determinados tipos de organização escolar "os professores são debilmente articulados não somente com a administração, mas também são debilmente articulados entre si”34 (OGAWA, 1984, p. 14 apud LIMA, 2011, p. $61)$.

Embora reconheçam dificuldades estruturais, muitos entrevistados acreditam que os próprios atores da organização também contribuem de alguma forma para a construção desse ambiente. Nesse sentido, tanto professores de projeto quanto de turmas regulares apontam problemas relacionados à pouca colaboração docente e preocupação por parte dos professores em relação a inovações em sua prática pedagógica, ausência de objetivos claros por parte da gestão, e de uma liderança compartilhada.

A ausência de um espaço de troca e os escassos encontros entre os docentes aparecem com frequência nos relatos. As interações ficam restritas basicamente a encontros rápidos nos corredores, intervalos e recreios, sem que sejam pensados trabalhos conjuntos entre os segmentos, e até mesmo dentro das próprias disciplinas. Quando perguntamos sobre a articulação entre os conteúdos dos diversos anos, os professores dizem que seguem as orientações curriculares

\footnotetext{
34،"Teachers are not only loosely coupled with administration, but they are also loosely coupled with each other." (OGAWA, 1984, p. 14 apud LIMA, 2011, p. 61)
} 
externas, e que, a partir daí, "cada um faz o seu" - num movimento parecido com a "presunção de competência" mencionada por Lima (2011). O momento de trabalho pedagógico que têm fica basicamente restrito aos dias de blocagem ${ }^{35}$, que, segundo os entrevistados, não possibilita uma articulação do trabalho docente propriamente dita, dado que esse dia não é o mesmo para todos os professores. Apesar de sofrer a influência de fatores externos, esse quadro também parece se configurar a partir da disposição que os agentes demonstram para a colaboração entre si.

Nesse mesmo sentido, na percepção dos agentes, os centros de estudo são usados especialmente para fins administrativos, para prestação de contas e indagação sobre compra de material, não constituindo um espaço de troca. Para além disso, costumam ocorrer duas vezes ao ano, o que é considerado insuficiente para o fechamento de projetos e para os trabalhos em conjunto. O principal fator que consideram responsável por essa pouca articulação docente é a ausência de um coordenador pedagógico - uma característica mais "estrutural", como visto anteriormente. No entanto, os docentes não parecem adotar muitas iniciativas voltadas a reverter essa situação. Assim é que, por exemplo, nota-se recorrentemente o discurso de que "cada um é um líder", não no sentido de uma liderança distribuída propriamente dita, mas no sentido de que "cada um rema seu barco", é "cada um por si" - expressões também reiteradas em suas falas.

Quando se trata de um enfoque pedagógico, muitos agentes dizem ter dificuldade em identificar um projeto maior, um objetivo principal vindo da equipe gestora e compartilhado com a comunidade escolar - um componente importante para a compreensão do conceito de liderança escolar (LEITHWOOD, 2009). Na percepção de um dos entrevistados, ainda, a falta de interesse na questão pedagógica se estenderia a outros agentes na organização, como professores que se limitariam a fazer o mínimo necessário, não se mostrando proativos em pensar novas metodologias e abordagens.

\footnotetext{
${ }^{35}$ Os dias de blocagem se aplicam aos anos iniciais, e às turmas de projeto de aceleração da aprendizagem (tanto dos anos iniciais, quanto dos anos finais). Os alunos dessas turmas têm apenas um professor generalista para trabalhar todas as disciplinas, à exceção de Educação Física, Língua Estrangeira e Artes/Música. Essas disciplinas são ministradas por professores diferentes e reunidas em apenas um dia - chamado dia de blocagem - quando os professores regentes da turma têm, então, um momento para planejamento de aula ou, no caso dos professores dos projetos, reuniões mensais de capacitação fora da escola.
} 
Aliada a essa falta de um enfoque pedagógico, aparece, ainda, a relevância de uma liderança compartilhada na percepção de certos agentes. Uma das professoras entrevistadas menciona que, por ainda ser cadastrada na lista de emails da outra escola em que trabalhava anteriormente, ela ainda recebia circulares e/ou informes de cursos de capacitação que estavam acontecendo - o que já não ocorria na Escola Sigma. A professora afirma que por vezes perdia os cursos por não ter o repasse das informações.

Nesse ponto, reconhece as dificuldades estruturais (como a sobrecarga de trabalho para poucos funcionários) que podem impactar essa dificuldade de comunicação entre a equipe gestora e os membros da comunidade escolar. Contudo, faz também uma sugestão implícita de que práticas no interior da organização contribuem para um entrosamento maior ou menor entre os docentes, o que, por sua vez, pode contribuir para melhores resultados escolares. Entre essas práticas que poderiam fazer "as coisas rolarem de maneira melhor aqui dentro [da escola]", a professora menciona a elaboração do projeto político-pedagógico em conjunto, da qual ela ainda não teria participado, o maior acesso às informações e decisões tomadas, e a maior participação dos diversos agentes nesse processo. A percepção da professora reflete a importância do que Marks e Printy (2003) chamaram de Liderança Integrada, uma espécie de síntese entre um enfoque instrucional e a distribuição da liderança entre os diversos membros da comunidade escolar, para além do gestor.

Em suma, a Escola Sigma é percebida principalmente como uma organização muito complexa. Embora seja um lugar em que muitos agentes ainda se mostram satisfeitos de trabalhar, principalmente por conta da localização geográfica, essa percepção vem se alternado em virtude da mudança no público atendido. Para além disso, percebe-se uma dificuldade de criação e manutenção de um ambiente propício à aprendizagem e de enfoque pedagógico, devido a desafios relacionados a questões externas e estruturais, bem como internas à organização. Quanto às primeiras, chama atenção a falta de funcionários - sobretudo de um coordenador pedagógico - diante da quantidade de professores e alunos em diferentes etapas de ensino na escola, para além de problemas relacionados ao corpo discente. Quanto às questões internas, percebe-se a hegemonia de uma crença segundo a qual a principal função da escola não seria exatamente ensinar. Isso parece decorrer de uma concepção pedagógica que concebe a socialização, a 
formação para a cidadania e o processo de ensino-aprendizagem como elementos relativamente apartados. Esse ponto torna-se ainda mais relevante quando se implementam projetos de correção de fluxo para alunos com atraso escolar, a exemplo das classes de aceleração - que conformam essencialmente uma intervenção pedagógica (SAMPAIO, 2000).

A Escola Sigma constitui um exemplo de escola de enorme porte que vivencia uma escassez de recursos materiais e humanos, o que pode gerar uma espécie de competição pelos poucos recursos existentes. Essa situação acaba sendo agravada diante da demanda adicional que representam os projetos de correção de fluxo e demais políticas recentemente implantadas, como as de avaliação externa e responsabilização. Nesse contexto, como pontuam Costa e Castanheira (2015), os processos de decisão, gestão e liderança assumem mais ainda uma dimensão ética e valorativa. A discricionariedade exercida pelos agentes escolares - expressa pela oferta de condições iguais a todos os alunos, pela mobilização de mais recursos àqueles considerados promissores ou merecedores, ou pela prioridade dada aos alunos com dificuldade de aprendizagem - implica uma avaliação moral por parte dos atores da linha de frente. Esses juízos e valores, por sua vez, estão intimamente relacionados à identidade percebida do seu principal cidadão-usuário: os próprios alunos. Partindo desse contexto, analisamos no próximo capítulo as percepções desses atores sobre os alunos da Escola Sigma, em especial daqueles com dificuldade e atraso escolar - alvo da política de correção de fluxo implementada - e sobre a própria política em si. 


\section{5 \\ Percepções e discricionariedade: executando e fazendo a política no nível da escola}

O capítulo anterior buscou contemplar um pouco do contexto institucional e organizacional em que a política em tela foi implementada na escola Sigma. Após uma breve descrição da política, passamos à análise da escola selecionada, tanto por meio de dados quantitativos, quanto por meio das percepções dos agentes entrevistados. Na análise inicial desse material qualitativo, foi possível captar algumas dinâmicas relacionais entre os agentes implementadores diretos (gestores e professores) e um pouco de sua percepção sobre os alunos, que constituem o principal cidadão-usuário da educação pública. Quanto à relação entre os agentes implementadores na Escola Sigma, percebe-se principalmente uma baixa integração docente, uma "articulação débil”" entre os professores. Essa situação é atribuída a condições estruturais da escola (como seu tamanho e a falta de funcionários), e também a elementos internos da organização, como a ausência de uma gestão compartilhada e de um projeto político-pedagógico claro.

Nas percepções iniciais sobre os alunos, pôde-se observar que predomina uma visão desses indivíduos como "usuários não cooperativos", no sentido de que não colaboram com o serviço que os burocratas de nível de rua precisam prestar, isto é, o ensino-aprendizagem. Essa percepção, na qual estão implicados diversos valores (principalmente a valorização de um ethos de ascensão social pela escola), ganha tamanha hegemonia na escola, que o próprio serviço público a ser oferecido a esses alunos começa a ser ressignificado. Em outras palavras, a função da escola para esses indivíduos passa a adquirir um foco socializador/disciplinador, que acaba por deixar em segundo plano sua missão pedagógica propriamente dita, de formação por meio do conhecimento escolar.

Neste capítulo, busca-se aprofundar as percepções dos agentes a respeito dos alunos com atraso escolar que constituem o público-alvo da política, bem como sobre a política propriamente dita, acompanhada de algumas práticas discricionárias. Nesse sentido, buscamos contemplar em certa medida as outras 
duas principais dinâmicas relacionais que Maynard-Moody e Musheno (2003) apontam como características do trabalho da linha de frente, para além da relação dos agentes com seus colegas de trabalho (os outros agentes implementadores na organização). Essas duas dinâmicas correspondem à interação com o cidadãousuário e com o "sistema", aqui compreendido como as diretrizes formais da política e seus elaboradores nos escalões superiores.

Como será visto ao longo da seção 5.1, prevalece uma relação tensa entre os implementadores da política de correção de fluxo no nível da escola e os alunos que se constituem como público-alvo dessa política. Podem-se perceber também alguns indícios de conflito nas relações entre os agentes implementadores. Esses conflitos parecem decorrer de percepções diferentes que eles apresentam sobre os alunos inseridos nessas turmas, visto que alguns professores se mostram mais compreensivos do que outros em relação às razões pelas quais os alunos de projeto se comportam da forma como o fazem. Consequentemente, apresentam críticas mais ou menos contundentes à postura dos demais agentes diante dessa situação e à atenção que o trabalho com os projetos recebe na escola. Cabe destacar que, antes da análise qualitativa mais profunda a respeito das percepções sobre esses alunos, a seção se inicia com uma breve exploração de dados do Censo Escolar a respeito da distribuição desses alunos na escola, segundo sexo/cor. Essa iniciativa se justifica com base nos achados de diversas pesquisas em Sociologia da Educação que indicam que o perfil sociodemográfico dos alunos com atraso escolar decorrente de repetências tende a ser bem específico. Nesse sentido, buscamos saber quem eram majoritariamente os "alunos de projeto" na Escola Sigma.

A seção 5.2 procura tratar da percepção dos agentes sobre as algumas das diretrizes formais da política em tela. Nesse sentido, trazemos o discurso oficial da política no que diz respeito a aspectos específicos, como: o formato de polivalência do professor, previsto no trabalho com os projetos nos anos finais do Ensino Fundamental, e a metodologia padronizada que deveria ser seguida. Aos discursos oficiais sobre esses aspectos, comparamos as percepções dos agentes implementadores no nível da escola sobre os mesmos tópicos, indicando algumas ações discricionárias adotadas como estratégias de enfrentamento àquilo que consideravam inadequado à realidade da escola e/ou dos alunos. Nesse sentido, percebem-se alguns esforços de exercício da discricionariedade principalmente 
como uma forma de melhor atender aos alunos, tornando a política mais significativa para eles, na percepção dos agentes.

$\mathrm{Na}$ seção 5.3, por fim, serão apresentados outros indícios de práticas discricionárias, envolvendo mais especificamente o encaminhamento de alunos para as turmas de projetos. Trata-se de informações que puderam ser identificados a partir de uma incursão exploratória sobre os dados do Censo Escolar relativos à escola secionada. Com esse movimento, foi possível verificar que determinados alunos matriculados em turmas de projeto não apresentavam a distorção idadesérie formalmente prevista, de dois anos ou mais, ao passo que outros alunos que tinham essa defasagem não pareciam ter sido atingidos pelos projetos. Partindo dessa análise exploratória, aventamos a hipótese de que poderia haver outra racionalidade por trás do encaminhamento desses alunos, que estivesse relacionada a diferentes interpretações da política, bem como a percepções diversas sobre o que precisam/merecem esses alunos. Esse último ponto será explorado no capítulo 6 , em que se perceberão tratamentos relativamente diferenciados a alunos considerados mais ou menos "merecedores".

\section{1.}

Percepções sobre o público-alvo da política: os "alunos de projeto"

O estudo de Lima (2016), além de reconstituir a política de correção de fluxo implementada no município do Rio de Janeiro, também investiga o perfil sociodemográfico e a trajetória dos alunos inseridos nos projetos. Para tanto, seleciona os alunos matriculados no $5^{\circ}$ ano do Ensino Fundamental em 2010, e os separa em dois grupos: aqueles que foram enturmados em projetos de correção de fluxo nos anos de 2011, 2012 e/ou 2013, e aqueles que não foram enturmados ao longo desses anos.

Suas conclusões condizem com os achados clássicos da Sociologia da Educação, constantemente reiterados em diversas pesquisas. No que diz respeito aos alunos enturmados em correção de fluxo no período investigado, pôde-se perceber que maioria deles era do sexo masculino, não-brancos, mais pobres ${ }^{36}$, apresentavam maior taxa de distorção idade-série e tinham mães menos

\footnotetext{
${ }^{36}$ Esse dado foi verificado por meio dos alunos que dispunham de NIS, um registro que indica vulnerabilidade social.
} 
escolarizadas do que aqueles que estiveram sempre matriculados em turmas regulares. Da mesma forma, os alunos que não haviam sido inseridos em turmas de correção de fluxo eram majoritariamente do sexo feminino, com nível mais baixo de pobreza, tinham mães mais escolarizadas e menor distorção idade-série.

Como dito anteriormente, a conclusão de que o perfil sociodemográfico dos alunos inseridos e não inseridos em turmas de projeto não é aleatório reforça diversos achados de pesquisa que indicam que determinados alunos se encontram mais vulneráveis ao fracasso escolar. Diante desses fatores, antes de analisarmos as percepções dos agentes da Escola Sigma a respeito do público-alvo da política, realizamos uma nova incursão nas bases de matrículas do Censo Escolar entre 2010 e 2014, recortadas para a escola estudada. Dessa vez, buscamos compreender a distribuição dos alunos nas turmas de correção de fluxo da escola, por sexo e cor. Na subseção abaixo, apresentamos os principais achados dessa investigação. Logo em seguida, na segunda subseção, tratamos mais especificamente das percepções dos agentes escolares a respeito dos alunos inseridos em turmas de correção de fluxo, comumente chamados de "alunos de projeto".

\subsubsection{O "aluno de projeto" segundo os dados do Censo Escolar}

As informações sociodemográficas de sexo e cor estão disponibilizadas apenas na base de matrículas do Censo Escolar, não estando presentes na base de turmas. Como será mais explorado no item 5.3 deste capítulo, parece ter havido uma subnotificação do número de matrículas em correção de fluxo no ano de 2014 na Escola Sigma, visto que nenhuma das quatro turmas de projeto organizadas este ano (apresentadas no quadro 1, p. 85) foram preenchidas como correção. As matrículas da turma de Realfabetização 1 foram consideradas multisseriadas na base de matrículas e as das demais turmas de projeto deste ano - as duas turmas de Aceleração 2A e a turma de Aceleração 3 - foram preenchidas com códigos relativo às turmas regulares. Por conta desse fator, que caracteriza um possível erro de preenchimento ou uma decisão discricionária dos agentes escolares, a análise do perfil sociodemográfico dos alunos inseridos em turmas de projeto no ano de 2014 conseguiu abranger apenas a turma Realfabetização 1, visto que as matrículas das outras turmas se mesclaram àquelas das turmas regulares. Nos 
demais anos (2010, 2011, 2012 e 2013), conseguimos verificar a distribuição dos alunos segundo sexo e cor em todas as turmas de projeto organizadas na escola.

$\mathrm{Na}$ Escola Sigma, no que diz respeito ao perfil de alunos atendidos nas turmas de projeto, verificamos uma situação semelhante ao que ocorreu na política de correção de fluxo da rede municipal do Rio de Janeiro como um todo (LIMA, 2016). Em sua maioria, eram os meninos negros (pretos e pardos) o principal público atingido por essa política. Em todos os anos, o percentual de meninos incluídos nas turmas de projeto foi significativamente superior ao percentual de meninas na mesma situação. Abaixo, apresentamos os dados relativos a 2013, quando essa diferença foi bastante nítida:

\section{Gráfico 2: Distribuição de alunos matriculados do 10 ao 9 o ano na Escola Sigma em 2013 por sexo}

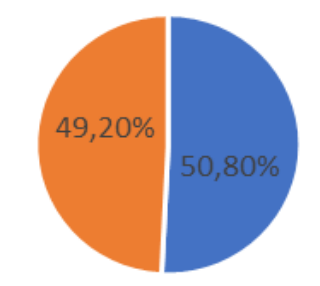

- Masculino - Feminino

\section{Gráfico 3: Distribuição de alunos matriculados em turmas de correção de Fluxo na Escola Sigma em 2013 por sexo}

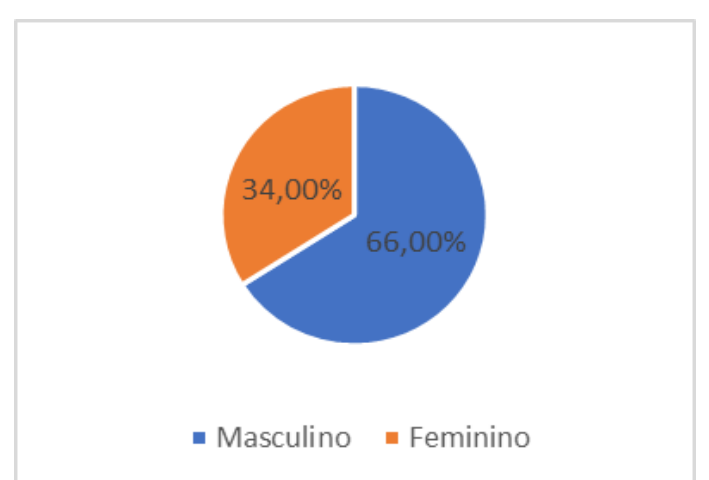

Fonte: Elaboração da autora, com base nos dados do Censo Escolar de 2013

Da mesma forma, observamos uma prevalência de crianças negras nas turmas de projeto, quando comparamos esses dados ao percentual dessas crianças matriculadas na escola. Nesse sentido, não observamos uma variação grande no percentual de crianças pretas nas duas condições $^{37}$, mas principalmente de crianças pardas. Destacamos o ano de 2011 como exemplo ilustrativo dessa situação:

\footnotetext{
${ }^{37}$ A exceção se encontra no ano de 2014, nos dados referentes à turma de Realfabetização 1 . Nesta turma, $42,1 \%$ dos alunos eram pardos, $21,1 \%$ eram pretos, $31,6 \%$ eram brancos, e 5,3\% não declararam a cor. Quando comparamos esses dados aos percentuais de alunos matriculados no $1^{\circ}$ ao $9^{\circ}$ ano segundo a cor declarada, observamos um aumento considerável no percentual de alunos pretos na turma de projeto, visto que esses representavam $12,8 \%$ dos alunos do $1^{\circ}$ ao $9^{\circ}$ ano. Os pardos representavam 44,8\%, os brancos, $38,9 \%$ e os demais (amarelos, indígenas e não declarados) somavam $3,5 \%$.
} 
Gráfico 4: Distribuição de alunos matriculados do $1^{\circ}$ ao 9o ano na Escola Sigma em 2011 por raça/cor
Gráfico 5: Distribuição de alunos matriculados em turmas de correção de fluxo na Escola Sigma em 2011 por raça/cor
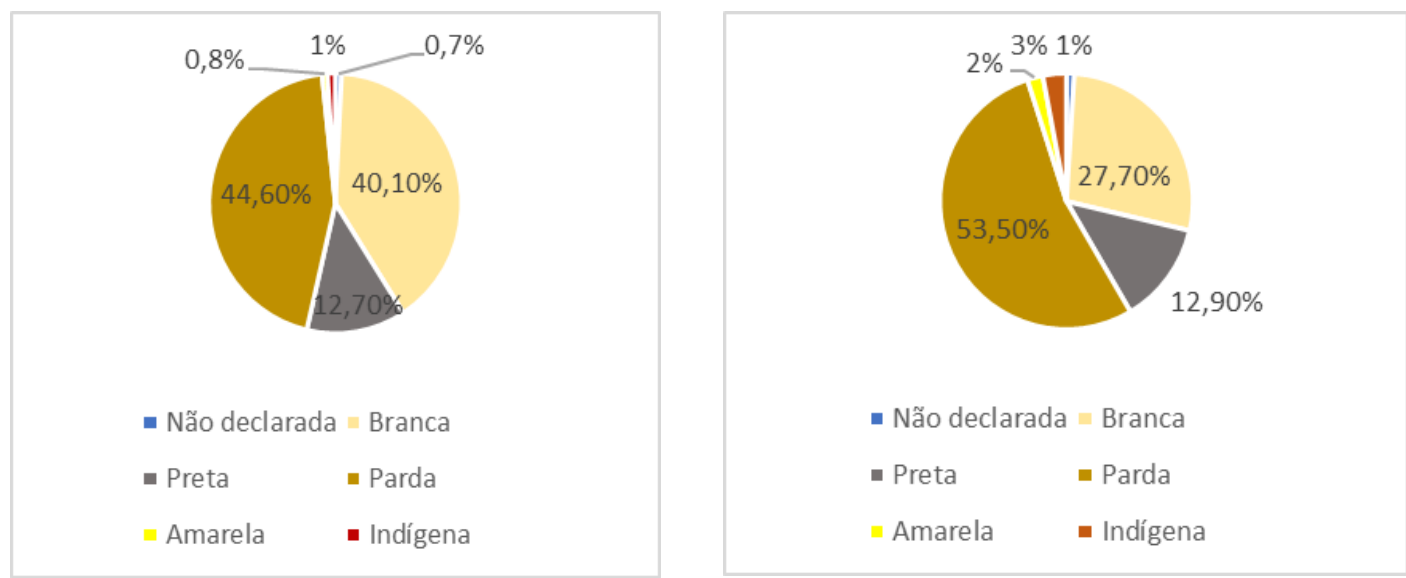

Fonte: Elaboração da autora, com base nos dados do Censo Escolar de 2011

A prevalência de estudantes meninos e negros entre aqueles que estão inseridos em turmas de correção de fluxo na Escola Sigma vai ao encontro do que mostra estudos como o de Ortigão e Aguiar (2013), que apontam os meninos negros como o grupo mais vulnerável ao fracasso escolar compreendido como repetência. Esses percentuais também podem ser relacionados de alguma forma ao estudo de Barbosa e Randall (2004) mencionado no capítulo 2, que aponta expectativas e avaliações docentes mais positivas em relação às meninas do que meninos. Da mesma forma, dialogam com o estudo de Carvalho (2004), que indica a influência do sexo e da cor dos alunos em um julgamento professoral mais ou menos positivo em relação à disciplina e desempenho dos estudantes, muitas vezes levando a uma maior indicação de meninos negros às atividades de reforço escolar, seja pela percepção de má disciplina ou de baixo aproveitamento.

Nesse sentido, partindo da premissa de que tanto meninas quanto meninos apresentam a mesma capacidade de aprendizagem, bem como negros e brancos, dados como esses sugerem a possibilidade de que expectativas maiores em relação a determinados alunos eventualmente influenciem seu desempenho escolar. Do mesmo modo, esses fatores podem vir a influenciar a percepção dos agentes escolares quanto aos alunos que devam ser encaminhados aos projetos de correção de fluxo. Como será visto no capítulo 6, ainda que o direcionamento de alunos para essas turmas deva ser feito de acordo com a distorção idade-série, alguns 
indícios de discricionariedade podem ser observados. Neste caso, diante das limitações desta pesquisa, não foi possível perceber uma influência nítida do sexo e da cor do estudante nesse processo segundo a percepção dos agentes, ao contrário do que acontece com a valorização de um ethos de esforço e dedicação à escola.

Após essa breve análise realizada a partir de uma incursão sobre dados quantitativos, retomamos a seguir a investigação qualitativa das percepções dos agentes escolares sobre esses alunos inseridos em turmas de correção de fluxo. $\mathrm{Na}$ próxima seção, tornam-se mais claras as avaliações dos agentes a respeito desses alunos de acordo com um ethos de ascensão social pela escola.

\subsubsection{Percepções sobre "o aluno de projeto" na Escola Sigma}

Diversos são os fragmentos das entrevistas com os agentes em que eles se dedicam à construção da identidade do principal cidadão-usuário do serviço público oferecido: os/as alunos/as. Como prenunciado no capítulo anterior, o discurso que predomina na percepção dos entrevistados é que eles recebem um alunado cada vez mais desinteressado e pouco disposto a estudar e aprender, cujas famílias tampouco se preocupam com seu aprendizado. Para além disso, não raramente a dificuldade de aprendizagem que apresentam é de certa forma patologizada - ou seja, encarada como fruto de problemas psicológicos e de saúde, cuja resolução está fora da alçada da escola - ou compreendida como resultado de mau comportamento. Essa compreensão quase automática da ideia de "dificuldade de aprendizagem" como uma deficiência cognitiva também constitui uma interpretação possível da fala abaixo:

O aluno do projeto... você tem... não é como se você fosse dividir a pessoa. Mas o aluno do projeto, você tem aluno que tem problema emocional, você tem aluno que tem problema cognitivo, e você tem o aluno que é, vamos botar assim, vamos classificar, de uma maneira errada, "preguiçoso". Você tem nessa turma três tipos de pessoas. Então, praquele que tem dificuldade de aprender, você consegue fazer alguma coisa. Mas, assim, aquele que é preguiçoso, consegue, mas... tá ali. Mas aquele que tem um problema no comportamento... é difícil. Aí esse pega. E esse eu vejo, pode ser que eu esteja enganada - mas vamos botar assim, isso é minha opinião pessoal, não foi uma estatística, não fiz pesquisa... numa turma de $20 \mathrm{de}$ projeto, eu digo pra você que... mais de $50 \%$ tem problema de comportamento. (Diretora Adjunta) 
$\mathrm{Na}$ classificação tripartida dos alunos de projeto, à "dificuldade de aprender" corresponde o "aluno que tem problema cognitivo", da mesma forma que ao "problema de comportamento" corresponde o "problema emocional", estando o "aluno preguiçoso" ausente de um sinônimo correspondente. De qualquer modo, em todos os perfis identitários estipulados, os problemas aparecem localizados exclusivamente no aluno, sejam eles considerados cognitivos (dificuldade de aprendizagem), emocionais (de comportamento) ou morais (preguiça, desinteresse). Como menciona Patto (1996, p. 49), trata-se de uma perspectiva bastante recorrente a respeito das classes populares, consideradas como depositárias de diversos defeitos (desinteresse, agressividade, imoralidade, entre outros).

Contudo, algumas percepções heterogêneas puderam ser constatadas. Embora a falta de interesse por parte de muitos alunos seja reconhecida pela grande maioria dos agentes, incluindo alguns próprios alunos, a forma de atribuir sentido a esse fenômeno difere entre os entrevistados. Ainda que a maioria deles signifique esse desinteresse, comumente expresso em frases como "não querem nada", como uma falha moral dos indivíduos e de suas famílias, outros demonstram um maior esforço compreensivo em relação a esse diagnóstico. A professora Esther, por exemplo, menciona que infelizmente a realidade de grande parte dos alunos consiste em amigos e familiares que foram trabalhar no $\mathrm{Mc}$ Donald's, ou que foram fazer curso técnico, ou que seguiram carreira militar. Sendo poucos os que "vão trilhar o caminho da universidade", muitos "não veem muita razão de estar aqui, razão para estudar". Seu discurso ecoa algumas constatações da Sociologia da Educação, sobretudo a explicação bourdieusiana das baixas expectativas dos alunos das classes populares em relação à trajetória escolar, muitas vezes considerada um investimento demasiadamente longo e cujo retorno é pouco provável.

Roger, ex-professor de turma de projetos nos anos finais, também apresenta uma visão aliada à compreensão reprodutivista das desigualdades escolares e da consequente atitude negativa que esse público apresenta diante da escola. Segundo ele, muitos alunos já têm a consciência de que a educação pública não muda a vida. O problema, em suas palavras, é que "eles chutam o balde, não sabem se organizar". Ao comentar especificamente sobre os alunos inseridos nos projetos, os descreve como os mais estigmatizados na escola, principalmente em função do 
mau comportamento que apresentam. Nesse sentido, menciona ainda um agravante dentro dessas turmas, que seriam os alunos vindos de outras escolas (onde muitas vezes não há turmas de projeto). Para o professor, esses são justamente aqueles que "dão maior problema de comportamento" e que muitas vezes fazem questão de afirmar sua identidade por meio do medo e da violência:

Eles têm um perfil até mais de assim... alguns tomam mais partido, por exemplo, pelo tráfico. Então, é claro que eles não são aquilo que eles querem reproduzir aqui, né, mas eles são reprimidos o tempo todo lá. Eles são reprimidos lá na comunidade, são reprimidos no asfalto, e o único momento em que eles podem se servir de algum poder é na escola. E aí quem tem que aturar essa pressão somos nós professores e a direção. Só que a maior parte dos professores e da direção, como uma parcela considerável da sociedade brasileira... a percepção deles é que tudo é a mesma coisa e se tem qualquer tipo de comportamento que seria desviante, né... a gente tem que punir, prender, e... assim, é um desafio muito grande, é contínuo, é um desafio com eles e com os colegas de profissão. (Professor Roger)

Na percepção desse professor, esses alunos estão cientes da exclusão que sofrem na comunidade onde vivem e no asfalto. Diante desse contexto, ele afirma que os alunos o respeitam, mas que, para outras pessoas na escola, o respeito se dá com base no medo - o tipo de relação que eles mais conhecem: "se eu não estiver, se a diretora não estiver, eles vão querer se impor pela maneira que eles veem as pessoas se impondo onde eles moram e no asfalto, que é através do medo". Nesse sentido, menciona que alguns alunos dessa turma ameaçavam os alunos mais novos, o que caracteriza como uma situação horrível, mas que é "compreensível, porque é assim que eles sofrem lá onde eles vivem”. Esse relato específico quanto ao que pode ocorrer quando o professor regente está ausente se alinha com a percepção de outros agentes escolares em relação aos problemas com as turmas de projeto principalmente nas quartas-feiras. Esse era o dia da blocagem, quando os alunos tinham aula de Educação Física, Língua Estrangeira e Artes/Música com outros professores, estando o professor regente fora da escola. Alguns agentes entrevistados mencionavam que esses eram os dias mais complicados, porque esses alunos - já considerados mais "problemáticos" - ficavam sem a principal referência que tinham, que era o professor polivalente.

Seu relato, portanto, embora se alinhe à percepção de outros agentes no que diz respeito à existência de problemas comportamentais por parte de determinados alunos de projeto, constrói uma interpretação explicativa diferente para eles. Para o professor, essa atitude negativa diante da escola e de membros da comunidade 
escolar consiste na reprodução involuntária do que esses mesmos alunos sofrem no interior e, principalmente, no exterior da escola - repressão e exclusão.

Em sua fala constata-se, ainda, o reconhecimento de outro problema: a postura dos outros agentes implementadores da política (professores e gestores) diante dessas atitudes dos alunos. Para o professor, grande parte dos agentes escolares enxergam o "aluno de projeto" como um aluno complicado, que tem problemas de comportamento e que são mal-educados, gerando uma grande resistência em relação a eles. A reação da comunidade escolar ao comportamento agressivo e indisciplinado desses sujeitos, na percepção do professor entrevistado, é o desejo de mais repreensão e punição.

Como assinala o professor, trata-se de um fenômeno comum na sociedade brasileira como um todo, cujos valores morais e o senso comum muitas vezes apontam para um punitivismo e desejo de repressão. Maynard-Moody e Musheno (2003), ao tratar especificamente dos professores enquanto burocratas de nível de rua, também mencionam essa "identidade ocupacional bipolar" (p. 59) percebida pelos agentes. Ao mesmo tempo em que precisam garantir a aprendizagem, os professores têm que lidar com os problemas imediatos de comportamento dos alunos. A depender do agente entrevistado, um "bom professor" é identificado como aquele que focaliza o processo de ensino-aprendizagem, ou aquele que sabe "lidar" com os jovens nas salas de aula e nos corredores. Aqueles que privilegiam a dimensão disciplinadora lamentam que sua postura mais agressiva possa lhes trazer problemas com a administração, com os pais e com as autoridades legais. Essa percepção torna-se mais clara no relato de outra professora, segundo a qual a sociedade mudou desde a época em que era criança, quando "não tinha coitadinho, tinha o chinelo ou a vara". Atualmente, ela afirma que não se pode mais tomar atitude, sugerindo haver uma proteção exacerbada do adolescente.

O relato do professor Roger assinala, portanto, a existência de desafios não somente nas interações com o público-alvo dos projetos, mas também com os colegas de trabalho, os outros agentes implementadores da política. No entanto, apesar desses conflitos organizacionais, o professor apresenta mais uma vez um esforço compreensivo e empático em relação a esses agentes, como tinha feito em relação ao comportamento dos alunos anteriormente. Em uma espécie de movimento hermenêutico, o próprio agente entrevistado se mostra capaz de 
"compreender todos esses atores", sufocados diante de um quadro de crise mais profunda:

Mas assim, a crise é tão grande, né, que... na verdade a gente consegue compreender todos esses atores. A direção sufocada, os professores estão sufocados. E chegar aqui e ouvir, né... má criação, falta de respeito, a gente não quer saber disso, a gente não tem mais saco para aturar esse tipo de coisa. A gente quer afastar e deixar longe da gente. (Professor Roger)

A caracterização dessa crise, por sua vez, não é construída da mesma forma como são apresentados o comportamento agressivo dos alunos das turmas de projeto e a reação dos colegas de trabalho a esse comportamento. Ao passo que o agente realça o caráter reprodutivo involuntário da atitude dos alunos, bem como o aspecto reativo quase natural dos agentes que estão sufocados, a crise é construída de forma crítica/dialética, como algo intencional e premeditado:

É crise de educação em todo país, né. Então assim, é a maneira de se ver educação como gerar crise. O desafio é gerar crise. [...] Há uma disputa política. Nessa disputa política, a percepção que a educação tem que continuar sucateada é uma percepção que vem sendo vencedora, porque uma educação que conscientize, fortaleça, capacite... vai disputar, vai disputar poder econômico, poder político do país, né, e isso não é desejado. [...] Há uma decisão política, então ele não é à toa. É essa decisão política de continuar deixando a educação sucateada. (Professor Roger)

Essa percepção quanto à intencionalidade por trás do estado de crise que vivenciam, gerada por um sistema mais amplo, será retomada nas seções seguintes que tratam das percepções dos agentes sobre "o sistema" e a política em si. De qualquer forma, segundo essa perspectiva, os sujeitos são praticamente percebidos como sendo dotados de uma espécie de autonomia imaginária, tendo sua capacidade de ação individual ou coletiva como atores enfraquecida. Os alunos são vistos quase que exclusivamente como um efeito de uma ideologia (uma decisão política) imposta de cima para baixo, sendo sua capacidade de resistência e agência criativa quase nula. Do mesmo modo, os demais agentes escolares são caracterizados como envoltos por essa crise mais ampla, sendo também reflexos e efeitos de uma ideologia dominante que vem se mostrando vencedora. Nessa percepção, pode-se dizer que a comunidade escolar como um todo é vista como uma espécie de vítima de um "sistema impiedoso, supra-humano" (LIMA, 2011, p. 41).

Em suma, ao passo que, na percepção de alguns agentes, os problemas apresentados pelos alunos são construídos como parte de sua "essência" (o aluno é 
preguiçoso, não quer nada, é indisciplinado, ou tem problema cognitivo), as percepções de professores como Esther e Roger constroem uma explicação externa para o desinteresse e o problema de comportamento apresentam. A percepção de Esther de que a baixa expectativa que esses alunos apresentam em relação à escola resulta dos exemplos mais próximos que têm, assim como a compreensão de Roger de que seu comportamento é uma reprodução de uma situação externa, contribuem para que o aluno não seja percebido como a única origem e a essência do próprio problema. $\mathrm{O}$ reconhecimento dessa externalidade, portanto, contribui para que uma outra identidade do cidadão-usuário seja construída, que não apenas aquela de alguém que essencialmente não quer nada e que tem mau comportamento, atrapalhando o trabalho escolar.

No entanto, ainda cabe refletir a respeito de outra perspectiva segundo a qual o desinteresse e a questão comportamental também podem ter origens internas à organização e à sua atividade de ensino-aprendizagem. Primeiramente, é importante atentar para a estreita relação que a (dificuldade de) aprendizagem escolar pode ter com o desinteresse e consequentes problemas de comportamento. Para tal, vale trazer a voz de alguns agentes escolares, incluindo os próprios alunos:

Aí eu reprovei porque eu não tinha muita noção. Tipo, lá na roça é tudo quietinho, aqui é tudo barulhento. Todo mundo falando pra caraca e aí eu não conseguia me concentrar. Aí no final do ano eu chutei o balde... parei de estudar, aí fiquei zoando. (Aluno de turma de projeto nos anos finais)

Eles próprios acabam se marginalizando porque eles percebem - a criança sabe que ela não sabe, entendeu? Então ela mesma entra nesse patamar de tipo, "eu sou o que não sabe". E muitas das vezes, ela acaba sendo uma criança que tem um comportamento mais agressivo, mais agitado. Até porque eu não sei qual que é a ordem. Eu não sei se ela é agitada e, por isso, não conseguiu aprender, ou se ela se tornou agitada porque ela não consegue acompanhar. (Professora Amanda)

Você no $1^{\circ}$ ano não conseguiu se alfabetizar, aí você vai pro $2^{\circ}$ ano, onde os textos aumentam, as dificuldades de interpretação aumentam, só que você ainda não sabe ler. Se você não sabia, agora você sabe menos ainda, aí começam as confusões dentro da sala de aula, criança não consegue fazer nada, começa a brincar, começa a bater, a rodar pela sala, e por aí vai. E aí toma a professora brigar e chamar a mãe. (Diretora Geral)

O aluno que tem dificuldade é difícil que ele centre. Aí já começa a fazer bagunça na sala. Aí manda chamar a mãe. A mãe vem, o aluno continua. Poucos acatam e engrenam em uma coisa de bem-estar. Né? (Professora Márcia)

O aluno cuja fala foi transcrita acima já tinha 17 anos à época de sua entrevista, quando cursava o último ano do projeto - que corresponderia à 
terminalidade do Ensino Fundamental ( $9^{\circ}$ ano). Em sua narrativa, conta que sua entrada na escola foi tardia, aos 9 anos de idade, pois morava em uma área rural de outro Estado, onde havia poucas escolas e professores. Essa dificuldade de acesso nas zonas rurais condiz com os resultados da pesquisa de Fernandes (2004) sobre os principais fatores que ainda se apresentam como empecilhos à equalização de oportunidades escolares. Ao chegar ao Rio de Janeiro, reprovou mais duas vezes - no quarto e no sexto ano - chegando a acumular uma distorção idade-série de 5 anos. Quando ia sair da escola, o chamaram para a turma de Aceleração. No entanto, isso ocorreu em outra escola, próxima à Escola Sigma, que era mais perto da onde morava. Ele havia sido transferido para a escola estudada há cerca de quatro semanas anteriormente à entrevista que fizemos, por conta de brigas com outros alunos, o que sugere problemas de comportamento que o aluno apresentava aos olhos dos agentes escolares. Como justificativa para suas dificuldades de aprendizagem que levaram a reprovações, menciona que, para além do atraso escolar oriundo de sua entrada tardia no sistema, tinha muita dificuldade de concentração por conta do barulho das escolas, que não correspondia à realidade do campo. $\mathrm{O}$ aluno chega a dizer que tentou estudar, para se interessar, mas que depois "chutou o balde" e começou a "zoar". Nesse ponto, pode-se perceber que um comportamento mais agitado e desinteressado em relação à escola surgiu de experiências negativas ocorridas dentro da própria escola, relacionadas à sua atividade-fim: o ensino-aprendizagem.

As falas das professoras e da diretora corroboram a ideia de que dificuldades no processo de aprendizagem podem ser a origem dos problemas de comportamento desses alunos. No momento em que a criança não consegue aprender ou acompanhar o ritmo das aulas, ela se torna dispersa e se engaja em outras atividades. A construção desse diagnóstico como efeito, e não como causa, pode contribuir para a relativização da percepção dos alunos em dificuldade escolar como aqueles que simplesmente "não querem nada". Nesse sentido, o desinteresse e a indisciplina que apresentam não representariam meras "falhas morais", mas um resultado de uma falha no seu processo de escolarização, o que poderia promover maior atenção a características da própria organização que influenciam esse processo.

No entanto, embora os agentes, quando diretamente questionados a respeito, sejam capazes de reconstruir possíveis origens para o desinteresse e indisciplina 
dos alunos com dificuldade escolar que não necessariamente residem neles próprios, a descrição automática desses estudantes como aqueles que "não querem nada" em outros momentos continua sendo comum. Da mesma forma, como visto no capítulo anterior, muitas vezes a missão pedagógica da escola é secundarizada diante da percepção de que problemas de disciplina exigem outro enfoque, sem levar em conta a estreita relação entre aprendizagem e comportamento.

Percebe-se nas falas acima que, quando esses problemas de comportamento advindos de uma dificuldade de aprendizagem começam a surgir, as medidas adotadas privilegiam a correção do efeito e não da causa propriamente dita. Dessa forma, "toma a professora brigar", "aí manda chamar a mãe", sem que se mencionem estratégias voltadas para recuperar essa dificuldade de aprendizagem.

Para além da estreita relação entre dificuldade de aprendizagem e indisciplina, outros fatores internos à organização podem contribuir para que se agravem os problemas de comportamento percebidos principalmente por parte dos alunos de projeto. Nesse sentido, é importante retomar a crítica implícita no relato do professor Roger, mencionada anteriormente, quanto à atitude predominantemente negativa dos agentes em relação aos projetos e aos alunos inseridos nessas turmas. Embora o professor tenha se mostrado empático com esses atores, e atribuído a maior responsabilidade por essa situação de crise a um sistema mais amplo, outros professores criticam de forma mais contundente essa postura por parte da organização. Dentre eles, uma professora menciona que o trabalho com os projetos era ignorado na escola, por vezes até mesmo no conselho de classe. Além disso, sempre foi visto como a "escória", como uma forma de "livrar" as outras turmas de um problema ao concentrarem os alunos considerados mais "problemáticos".

Na percepção dessa professora, o processo de exclusão e repreensão que os alunos dos projetos sofriam não eram somente externos, mas também internos. Seu relato sugere que a pouca colaboração docente, já mencionada na seção sobre a organização como um todo, parecia potencializada no caso das relações entre o projeto e as turmas regulares. Sugere, mais ainda, uma atitude de rejeição em relação aos projetos e aos alunos nele enturmados.

Nesse sentido, passando de um movimento compreensivo quanto à demanda adicional que os projetos representam em uma escola já sobrecarregada de tarefas, e aos problemas de comportamento associados a esses alunos, cabe analisar a 
medida em que essas crenças e práticas podem impactar, reforçar e retroalimentar esses próprios fenômenos. Um exemplo desse processo cíclico é a fala de um aluno egresso de projeto dos anos finais, que no momento da entrevista já estava no Ensino Médio, a respeito dos problemas de comportamento que eram atribuídos a eles:

$\mathrm{Na}$ escola, qualquer coisa que alguém fazia, aprontava, caía pra gente, porque a gente é do Acelera, entendeu? [...] Tipo assim, se tivesse bagunça no corredor, Caía pra cima do projeto. Não era a $6^{\mathrm{a}}$ série, $7^{\circ}$ ano, $8^{\circ} \ldots$ não. E tava todo mundo no meio. E só caía pra cima do projeto, não caía pra cima de todo mundo. Então eu achava isso aí uma coisa muito pesada, caía tudo pra cima da gente, a gente não entendia nada, entendeu? Pra gente tudo era só zuação, farra... [...] e só acusavam a gente. (Aluno egresso de projeto dos anos finais)

A narrativa do aluno inserido em turma de projeto, agora egresso, constrói a identidade desses alunos como alvo de constantes acusações por parte da comunidade escolar como um todo (diretores, professores e demais alunos). Seu relato se alinha à fala de um aluno regular que naturaliza a culpabilização dos "alunos de projeto" pela maior parte das ocorrências de desordem e agitação constatadas na escola: "a maioria das coisas que vocês virem quebradas por aí, pode botar na cabeça que foi eles". A fala desse aluno sugere, portanto, uma presunção de culpabilidade em torno dos alunos de projeto quando se tratava de desordens e depredações na escola.

Percepções como essas que predominam dentro da escola estudada podem ser consideradas como causas e efeitos em uma relação dialética: por um lado, ancoram-se em dificuldades reais, observadas no cotidiano; por outro, contribuem para a constituição e manutenção dessa posição do "aluno de projeto" como um aluno problemático, desinteressado e indisciplinado. Esse tipo de significado acaba por tornar-se naturalizado no discurso de diversos agentes, a ponto de atingir o estado de "senso comum" no interior da organização, praticamente deixando de ser alvo de críticas, revisões e reelaborações. Como pontuado por Habermas (1987), adquire legitimidade ao ser institucionalizado.

Da mesma forma, as expectativas quanto a esses alunos - ainda que também ancoradas em uma observação da realidade externa, como aponta o relato já mencionado da professora Esther - também podem contribuir para a construção identitária desses sujeitos e de suas próprias chances futuras. Nesse sentido, vale mencionar a percepção da professora Isabel, ex-professora de projeto nos anos finais, sobre a inutilidade que teria a reprovação dos alunos da última turma de 
projeto que teve, dentre os quais muitos apresentavam problemas básicos em leitura e escrita: "Eu vou reprovar esses alunos pra quê? Com 16, 17 anos. Eu vou conseguir, a escola vai conseguir alfabetizar esse aluno? Não. Mesmo se reprovasse... Aí aprovávamos, vai trabalhar na farmácia, ou no supermercado". Em seu relato, percebe-se uma consciência semelhante à da professora Esther quanto à inserção profissional mais comum que esses alunos apresentam. Contudo, cabe refletir sobre a possibilidade de que essa percepção, ainda que ancorada em uma observação do cotidiano dos alunos e de suas famílias, contribua para que esse destino se concretize na medida em que, por exemplo, menos esforços sejam dedicados ao seu ensino, ao antecipar poucas chances de retorno.

Por outro lado, outros relatos apontam para esforços docentes em criar expectativas positivas sobre os alunos, sendo algumas dessas iniciativas reconhecidas pelos próprios alunos. Célia, uma das ex-professoras de turmas de projeto que trabalhou com essas turmas nos anos finais por diversos anos seguidos, apresentou uma percepção bastante positiva sobre esse trabalho ao longo de toda sua entrevista. Segundo ela, até mesmo a dedicação e o interesse dos seus alunos nos projetos não eram baixos - ao contrário do que relatou a maioria dos outros agentes. Um dos fatores a que ela atribui o engajamento de seus alunos são as expectativas verdadeiras que depositava neles, e que lhes transmitia:

Eles tinham que se dedicar mesmo, tinham... e também quando você coloca a esperança como verdade, não só como esperança, que eles iam pro segundo grau... Isso você falava todo dia, pra mostrar a eles que você não tava mentindo. Eu falei pra eles "imagine, se eu tiver falando uma coisa pra vocês que vocês descubram que não é verdade minha que eu estou tentando enganar vocês", entendeu? [...] Então todo dia você coloca expectativa, as esperanças né, mas pra você fazer isso, você tem que ter dentro de você. Se você não estiver sendo verdadeira, eles percebem. Eles têm esse lado também, eles percebem quem é você, sabe? (Professora Célia)

Para Célia, não basta o professor emitir palavras de encorajamentos aos alunos se ele realmente não sentir que é possível, pois os alunos são capazes de perceber a veracidade de suas expectativas. Para essa professora, como será visto adiante na seção a respeito das percepções sobre os projetos, de nada adiantava reclamar das parcerias, do formato engessado, e das falhas que o projeto tinha. Era necessário que quem estivesse à frente desse trabalho o transformasse, se 
apropriasse da ideia e fizesse seu melhor. Como também será visto mais à frente, no próximo capítulo, essa mesma agente apresentou o que chamaremos de "esforços extraordinários" para que uma aluna que considerava necessitada pudesse entrar nos projetos, ainda que não tivesse a distorção idade-série exigida, uma vez que avaliava positivamente esse trabalho. Em suma, sua percepção majoritariamente positiva da política e do que podia ser feito parece ter influenciado sua atuação enquanto professora (e implementadora) do projeto, bem como suas percepções quanto à eficácia dessa iniciativa para os alunos atendidos.

A percepção apresentada por essa professora quanto à sensibilidade dos alunos em relação às expectativas docentes parece ser confirmada no seguinte relato do aluno egresso entrevistado:

Quando eu fui do projeto, tinha um professor que nem ligava pra gente, entendeu? Pegava, botava nada no quadro, abria o livro, mandava a gente abrir a página, e se vira. Aí pegava o telefone dele e começava a mexer. Aí veio uma professora, o nome dela é até X, ela fez de tudo pra gente. Aí, a gente através dela começou a aprender, a se expressar cada vez mais. [...] Ela que, tipo assim, ajudou a gente, ela que se esforçou, entendeu? Ela dava aula de tudo pra gente nessa escola, fazia de tudo. [...] Que nem a professora dessa turma aqui, eu conheço ela, é uma professora boa, ela se dedica aos alunos, eu não tenho nada a dizer dela, porque eu já fui aluno dela e eu sei como é que ela é, ela é uma professora boa, ela se interessa pelos alunos dela, se tiver fazendo bagunça, ela chama o responsável... com ela não tem essa diferença. Eu até me orgulho nela, me inspiro nela. (Aluno egresso de projeto dos anos finais)

Apesar de o aluno não fazer referência à professora Célia, mencionada acima, seu depoimento se alinha à percepção dessa professora quanto à capacidade que os alunos teriam de sentir o quanto, de fato, seus professores acreditam neles. Mais ainda, a fala do aluno acima sugere que, da mesma forma que professores e diretores os julgam com base na posse ou não de um ethos, de "qualidade moral" relativa ao esforço, à dedicação, e ao "querer alguma coisa", uma avaliação semelhante pode ocorrer por parte dos alunos. Em outras palavras, os alunos (cidadãos-usuários) também podem levar em conta as crenças e os esforços genuínos dos agentes em relação a seu aprendizado no processo de decisão (consciente ou não) quanto ao seu empenho escolar. Trata-se, mais uma vez, de uma compreensão dialética de uma realidade multifacetada.

A análise das entrevistas com os diversos agentes escolares aponta para a hegemonia de uma percepção segundo a qual os alunos de projeto, ainda mais que o restante dos alunos na escola, são especialmente desinteressados e indisciplinados. Muitos reconhecem, ainda, que esses alunos apresentam uma 
autoestima baixíssima, oriunda das experiências de repetência e dificuldade de aprendizagem. Para alguns agentes, no entanto, seu principal problema sequer seria a dificuldade de aprendizagem, mas sim o mau comportamento e o "não querer nada", o que acaba tornando sua inserção nessas turmas ineficiente. Indo mais além, essa aproximação socioafetiva que os projetos propõem poderia ser até mesmo contraprodutiva no sentido que esses alunos "precisariam de algo mais rígido". Poucos são os questionamentos quanto à possibilidade de que esse comportamento seja efeito e não causa de uma dificuldade de engajamento com a escola promovida por fatores também internos à organização. Dentre os discursos dissonantes, estão as percepções mais compreensivas quanto à construção desse fracasso por fatores externos e internos, e certa condenação dessa postura predominante da comunidade escolar centrada na repreensão dos alunos.

Conforme buscou-se mostrar ao longo dessa seção, as percepções sobre o "aluno de projeto", ainda que baseadas na observação de eventos reais, podem contribuir para reforçar e reproduzir o lugar que esse sujeito assume. Mais ainda, as percepções que se têm desses alunos podem influenciar diretamente as práticas concretas que se verificam no interior da escola. Algumas dessas práticas serão discutidas no próximo capítulo, que trata do exercício político da discricionariedade dos agentes da linha de frente. A seguir, continuamos a investigar as percepções dos diferentes atores da comunidade escolar, agora passando do público-alvo da política para a política propriamente dita. Nesse sentido, já começamos a encontrar algumas ações discricionárias desses atores diante da percepção de que os limites e demandas da política não atendiam às necessidades dos alunos.

\section{2. \\ Percepções sobre a política: (re)significando e agindo sobre a proposta}

A terceira dinâmica relacional que Maynard-Moody e Musheno (2003) apontam como típica do trabalho no nível da rua é a relação com o chamado "sistema". Sob a ideia de "sistema" estariam englobados os políticos eleitos e os formuladores de política, outras agências de implementação da política em escalões superiores e a mídia (como formadora da opinião pública). Como pontuam os autores, os burocratas no nível da rua costumam nutrir um sentimento 
de pertencimento e mutualidade entre si através de uma cultura do "nós contra eles", que travam com o sistema. Ao passo que essas agências seriam o foco primário da narrativa do "agente do Estado", na maioria das histórias contadas pelos agentes elas aparecem como instituições sem conhecimento real da linha de frente, que muitas vezes precisam enfrentar para fazer aquilo que consideram certo e mais eficaz.

Como já mencionado na seção 4.3, em que tratamos da abordagem hermenêutica-dialética e dos conceitos de senso comum e vivência, os agentes do nível de rua costumam apresentar valores prático-morais advindos de sua experiência em um contexto que requer adaptação e improvisação. Esses agentes mostram-se, ainda, orgulhosos de seu pragmatismo, conquistados após muitos anos de "nível de rua". Muitas vezes consideram seu saber superior aos cálculos frios e distanciados de seus superiores, que interferem na autonomia de seu trabalho. Nesse sentido, muitas das demandas e diretrizes impostas pelas agências de nível central são consideradas irrealistas, limitadas e limitantes ao trabalho no nível da rua, levando-os a usar de sua discricionariedade para adaptá-las e, então, torná-las mais eficazes aos seus olhos. Nesse sentido, os autores pontuam que

Ao substituir as visões irrealistas e insustentáveis daqueles que têm autoridade formal e legítima por juízos pragmáticos, os trabalhadores de nível de rua se veem agindo de forma responsável [...], justificando decisões e ações como improvisações exequíveis de regras, leis e procedimentos irrealistas. (MAYNARD-MOODY e MUSHENO, 2003, p. 24)

Essas reflexões também são trazidas por Lima (2011) quando analisa especificamente a escola enquanto organização. Segundo o autor, a administração central no sistema de ensino, à qual os atores escolares estão submetidos, é percebida como "burocrática no sentido em que é gigantesca e inflexível, irracional e incoerente, ineficaz, ineficiente etc" (p. 42). O significado que grande parte dos atores atribuem à ideia de burocracia, portanto, não corresponde ao tipo de dominação racional-legal weberiano propriamente dito, mas sim a uma ideia de disfuncionalidade, disburocracia, controle, rigidez e ineficácia. Dessa forma, como menciona o autor, sempre que perceberem uma inconsistência entre as

\footnotetext{
38 "By substituting pragmatic judgments for the unrealistic and untenable views of those with formal and legitimate authority, street-level workers view themselves as acting responsibly. [They are taking on the burden of making moral and pragmatic judgments that alter citizens' everyday lives], justifying decisions and actions as workable improvisations of unrealistic rules, laws, and procedures." (MAYNARD-MOODY e MUSHENO, 2003, p. 24)
} 
exigências formalmente estabelecidas e os recursos existentes, a legitimidade das normas formais se enfraquece aos olhos dos atores. A partir de então, podem proceder à produção de regras alternativas, justificando-as a partir de outros tipos de racionalidade e com outras concepções de legitimidade (a exemplo do profissionalismo, autonomia, ou motivações pedagógicas).

Um processo semelhante a essa perda de legitimidade sob a ótica dos agentes, e a consequente produção de regras alternativas em que se engajaram, parece ter ocorrido na Escola Sigma em relação a dois elementos-chave que caracterizaram as políticas de correção de fluxo implementadas nos anos finais: a metodologia padronizada da Telessala (da Fundação Roberto Marinho) e a seleção de um professor especialista que atuasse como generalista nessas turmas, usando a tecnologia educacional das teleaulas.

Como visto no capítulo 4, a partir do ano de 2010, foram incorporadas ao Programa Reforço Escolar as tecnologias da Fundação Roberto Marinho de forma a viabilizar a correção do fluxo nos anos finais. Para tanto, foi implantado na rede municipal o Projeto Autonomia Carioca, que passou a ser denominado Aceleração 2 e Aceleração 3 pela SME. O Aceleração 2, destinados a alunos do $6^{\circ}$ ano com defasagem idade-série de dois anos ou mais, teria duração de dois anos, com vistas a acelerar o $6^{\circ}$ e $7^{\circ}$ anos no primeiro ano de projeto, e o $8^{\circ}$ e $9^{\circ}$ anos no segundo ano de projeto. Já o Aceleração 3 teria duração de um ano, sendo destinado aos alunos do $7^{\circ}$ ou $8^{\circ}$ ano com distorção idade-série que, em um ano, acelerariam o $8^{\circ}$ e o $9^{\circ}$ anos e concluiriam o Ensino Fundamental. Para promover a aceleração da aprendizagem desses alunos nos anos finais, o projeto utilizava a Metodologia Telessala, do Telecurso da Fundação Roberto Marinho.

Conforme pontuado por Lima (2016), a Metodologia Telecurso constituise principalmente de vídeos e livros didáticos originalmente usados na década de 1970, com vistas ao supletivo ou à aceleração da conclusão da educação básica de jovens e adultos em atraso escolar. Apesar de seu aspecto obsoleto, o site da fundação a descreve da seguinte forma:

Aplicada desde 1995, a Metodologia Telessala combina o melhor do conhecimento acadêmico na área pedagógica a um conjunto de ações (como formação de professores, acompanhamento e avaliação) que garante resultados bem-sucedidos em diferentes realidades e regiões do país. [...] O Telecurso é, 
desde 2001, currículo de referência nacional para o Exame Nacional para Certificação de Competências de Jovens e Adultos (Encceja). (Site da FRM) ${ }^{39}$

Para o trabalho com esses projetos nos anos finais, deveriam ser selecionados professores especialistas da rede (de Português, Matemática, História, Geografia etc), que passariam a atuar como generalistas nas turmas de aceleração. Dessa forma, ficariam responsáveis pelo ensino de todas as disciplinas do currículo, à exceção de Educação Física, Artes e Inglês, que seriam ensinadas por professores especialistas no dia de blocagem (às quartas-feiras). Para tanto, esses profissionais passariam por capacitação específica da Fundação Roberto Marinho, que os orientaria a respeito das tecnologias associadas à Metodologia Telessala.

Como aponta Lima (2016), esse tipo de intervenção pedagógica proposta - a estruturação da sala de aula de acordo com uma metodologia padronizada - se justificava no discurso oficial da secretaria a partir de experiências anteriores consideradas bem-sucedidas no que diz respeito à melhora da aprendizagem dos alunos. Contudo, a interferência dos projetos na autonomia dos professores e das escolas foi bastante criticada ao longo da implementação da política, sobretudo por parte do Sindicato Estadual dos Profissionais da Educação (SEPE). Além disso, desde o primeiro ano em que esses projetos entraram na rede, diversas audiências públicas foram realizadas na Câmara de Vereadores a respeito dos gastos dispendidos com as parcerias público-privadas realizadas pela SME com o IAS e FRM.

Críticas contundentes à metodologia da FRM, bem como ao formato de polivalência do professor para ministrar todos os conteúdos, foram bastante recorrentes nas entrevistas realizadas com os agentes escolares na Escola Sigma. As teleaulas que tinham que ser exibidas foram unanimemente consideradas ultrapassadas e distantes da realidade do aluno do projeto. Até mesmo a exprofessora de projeto Célia, para quem "todo aquele projeto é maravilhoso", faz uma ressalva em relação a ele: "só que em relação ao material didático, o projeto estava totalmente defasado".

Para muitos professores, essa metodologia só podia se justificar por uma espécie de "conchavo" entre a SME e a Fundação, visto que "muito dinheiro tinha

\footnotetext{
${ }^{39}$ Trecho retirado de http://www.frm.org.br/acoes/telecurso. Acesso em 4 de março de 2017.
} 
rolado" nessas parcerias, em sua ótica. Na percepção de uma ex-professora de projeto, os alunos chegavam a debochar do material, visto que eles tinham acesso a celulares e a diversas outras tecnologias, enquanto os vídeos traziam exemplos de máquinas de escrever e demais aparelhos antigos. Essa percepção é reforçada na fala de um aluno inserido na turma de projeto à época de sua entrevista, que comenta sobre as teleaulas em tom jocoso: "Tem aqueles caras, tipo, meio roceiro, de antigamente... a televisão ainda tinha aqueles bagulhos atrás... aqueles caixotes".

Como sintetiza Sabrina, a professora da turma de projeto dos anos finais remanescente na escola em 2016, eram dois os problemas da metodologia. Primeiramente, ela estava totalmente defasada em relação à realidade dos alunos e, em segundo lugar, ela não era voltada para aquele público, ou seja, para os adolescentes no Ensino Fundamental regular. Conforme pontua a professora, o material do Telecurso tinha sido desenvolvido para jovens e adultos que ainda não haviam terminado a educação básica, e que já estavam no mercado de trabalho: "Tanto é que você vê alguns temas de teleaula que são voltados para o trabalhador, não são voltados para um estudante adolescente, que não está trabalhando. Então, não faz sentido"

A percepção de que essa metodologia não fazia sentido levou diversos professores a fazerem adaptações e desenvolverem materiais alternativos às teleaulas, como uma estratégia de enfrentamento àquilo que consideravam ser ineficaz para aprendizagem de seus alunos. De acordo com a professora Sabrina, essas criações alternativas foram surgindo e ganhando força nas reuniões entre os professores de projeto realizadas nas CREs, como parte de seu processo de capacitação. Nesses encontros, os professores trocavam experiências sobre dinâmicas diferenciadas que vinham fazendo, a exemplo do trabalho com vídeos mais curtos do que as teleaulas - consideradas por alguns professores como muito longas para o público adolescente - e que seriam também mais interessantes por serem mais atuais e próximos do contexto dos alunos. Esse material era compartilhado entre os professores por meio de seus pendrives e, então, projetado na sala de aula.

Tummers e Bekkers (2014), ao investigar a medida em que a discricionariedade poderia afetar a percepção que os agentes implementadores têm da utilidade da política para o público-alvo, bem como sua disposição para 
implementá-la, encontram alguns resultados positivos. Ao aplicar um Survey a diversos profissionais de saúde mental holandês que estavam implementando uma nova política de reembolso, os autores perceberam que desfrutar de uma margem de liberdade na execução do programa aumentou o que chamaram de perceived client meaningfulness (a significância percebida da política para o cliente/usuário). Dessa forma, quando os burocratas do nível da rua estudados experimentaram uma discricionariedade maior, houve uma influência positiva em sua percepção quanto ao valor que aquela política poderia ter para o usuário, visto que poderiam fazer adaptações e torná-la mais relevante e efetiva para ele, lidando com suas especificidades. Essa percepção, por sua vez, parecia aumentar a disposição desses agentes em implementar a política (willingness to implement). Ao contrário, um controle burocrático rígido tendia a desmotivar os agentes implementadores. Isso se dava tanto porque uma margem de liberdade costumava ser, por si só, valorizada, quanto porque percebiam que, sem ela, não poderiam tornar a política mais significativa para o usuário e, com isso, muitas vezes viam menos sentido em executá-la.

Uma situação semelhante parece ter ocorrido com os agentes implementadores desta pesquisa no que toca ao material didático utilizado. Durante as entrevistas com os professores, foi possível notar que trabalhar com um material alternativo aumentava sua percepção da significância/utilidade da política para o público-alvo, pois podiam trazer dinâmicas e discussões mais relevantes para sua realidade. Nesse sentido, os professores se mostravam um pouco mais satisfeitos com o trabalho, uma vez que, ao longo do tempo, iam percebendo que não precisavam ficar totalmente "presos àquele formato engessado" que julgavam não contribuir para a aprendizagem dos alunos.

No entanto, como pontuam Tummers e Bekkers (2014), essas estratégias são possíveis quando as instituições ou organizações estão dispostas e são capazes de delegar autoridade relativa à tomada de decisão aos funcionários da linha de frente. Esse fator pode ser ainda mais notável em profissionais cujas expectativas de discricionariedade e autonomia contrariam as noções de controle burocrático, como era o caso dos professores diante da política de correção de fluxo, que previa uma padronização do trabalho pedagógico. Nesse sentido, vale recuperar alguns relatos distintos sobre a margem de liberdade que os agentes entrevistados percebiam ter para realizar essas adaptações no material. Vale, ainda, articulá-los 
ao que discutem Tummers e Bekkers (2014) sobre diferentes níveis de discricionariedade que podem ser experimentados pelos agentes dentro de uma mesma política. Segundo os autores, entre os fatores que influenciam esse fenômeno estão a personalidade do agente da linha de frente (por exemplo, mais "obediente" ou "rebelde") e o tipo de relação que mantém com os órgãos superiores, eventualmente permitindo que se façam mais ajustes na implementação.

A maioria dos professores entrevistados, quando perguntamos se tinham algum receio em relação à fiscalização externa de suas aulas, diziam se sentir bem mais "engessados" com a padronização no início:

No início, era muito rigoroso. Você era obrigado a dar as teleaulas. Todo dia tinha teleaula, você tinha que seguir toda aquela metodologia, o que era uma loucura, porque você não dava conta do conteúdo. [...] E a própria... GED [Gerência de Educação] da CRE, meio que peitava que a gente fizesse isso tudo. E aí imagina que você recebe a Fundação, uma visita surpresa, e você nunca fez aquela metodologia. $\mathrm{O}$ aluno não vai entender nada, né, a turma tinha que ter familiaridade com aquilo, porque imagina se eles não tivessem? Então você tinha que fazer aquela metodologia e seguir aquilo à risca. Então, até depois eu dei uma relaxada, que eu vi que não ia dar certo, porque senão eles não iam aprender conteúdo nenhum, e aí tinha dias que eu falei "não, vamos trabalhar de outra forma hoje, porque senão, a gente não faz nada". (Professora Sabrina).

Apesar do maior controle burocrático nos primeiros anos de implementação do projeto, os professores afirmaram que iam adquirindo uma percepção de progressiva liberdade ao longo dos anos. Embora não pudessem deixar de usar o material padronizado, sentiam que podiam ir fazendo algumas alterações e exercícios alternativos, desde que o "esqueleto comum" do projeto permanecesse.

No entanto, uma das ex-professoras de projeto nos anos finais, Marta, não descreveu um processo semelhante em relação a um maior controle burocrático que teria diminuído ao longo da implementação da política. Quando perguntamos se tinha algum receio quanto à fiscalização externa de suas aulas, ela disse que a Fundação gostava de ver as coisas feitas, os murais nas paredes, mas que ela podia levar vídeos, fazer brincadeiras e, enfim, montar a própria aula. Uma primeira interpretação construída a partir de seu relato foi, portanto, que a discricionariedade percebida por essa professora era relativamente maior do que a percebida por outros. Como pode-se perceber a partir dos eventos enumerados a seguir, essa professora parecia nutrir uma relação mais próxima com os agentes do escalão superior, o que possivelmente influenciava sua percepção de maior 
liberdade para agir sobre a proposta pedagógica, em comparação aos outros colegas.

A professora Marta havia entrado na Escola Sigma em 2015, no ano anterior àquele em que a entrevista foi realizada (2016), justamente para trabalhar com turmas de projetos. Como pontuado por diversos entrevistados, a CRE tinha uma espécie de "banco de informações" quanto aos professores que já vinham trabalhando com essas turmas, e que podiam ser mais facilmente transferidos para outras escolas em que se verificasse a necessidade desses professores. Essa professora tinha sido, então, transferida para a escola pesquisada para ser regente de turma de aceleração nos anos finais. À época, havia quatro dessas turmas de anos finais na escola - duas de manhã (umas das quais era a dela) e duas à tarde. Ao chegar à Escola Sigma, ela conta que não havia projetor disponível em sua sala, mas que ela então "mexeu os pauzinhos" e conseguiu ter acesso ao aparelho. Usando de uma racionalidade de recurso, reforçou que não dava para se ater ao material padronizado defasado, e que precisava do projetor para desenvolver suas atividades com o pendrive. Ela reconhece, ainda, que o outro professor de projeto que trabalhava em seu mesmo turno (e que estava na escola há mais tempo) tinha um desafio a mais porque não dispunha do aparelho, que parecia ser o único disponível. Quando ele precisava projetar, ela afirma que eles trocavam de sala.

Com base em seu relato, percebe-se que tinha uma relação mais próxima com as funcionárias da CRE, principalmente com aquelas responsáveis pela coordenação dos projetos, do que os outros professores. Ela havia sido, ainda, convidada pela Secretaria para compor a equipe de elaboração de material didático próprio dos projetos de aceleração, que viriam a substituir o material da FRM quando do término da parceria. O relato da professora sugere que a liberdade percebida para realizar atividades diferenciadas daquelas previstas na metodologia padronizada era bastante alta, a ponto de se tornar praticamente uma "exigência" que ela apresentava à funcionária da CRE para que fosse encaminhada para as turmas de projeto em outras escolas. A professora menciona que só aceitava ser transferida para outra escola para trabalhar com projetos se dispusesse dos recursos necessários para suas aulas (no caso, do projetor).

A entrevista com a professora Marta sugere também certa escassez de recursos materiais na Escola Sigma, já mencionada anteriormente na seção que trata das percepções sobre a escola. Diante dos poucos recursos existentes, a 
exemplo do projetor, seu relato levanta a possibilidade de que esses aparelhos não fossem disponibilizados facilmente para as "turmas de projeto", muitas vezes sendo necessário que os professores "mexessem os pauzinhos" ou se articulassem para consegui-los. Essa percepção também é compartilhada com a professora Sabrina. Ao mencionar as atividades alternativas que os professores trocavam uns com os outros nas reuniões na CRE, a professora afirma que ela enfrentava certas dificuldades dentro da escola para conseguir realizar essas atividades, diante da limitação de recursos disponíveis e da pouca mobilização percebida por parte dos agentes para disponibilizá-los. Em seu relato, afirma que por vezes precisava recorrer à "alguma pressão de fora" para a obtenção desses recursos.

Por fim, esses relatos sugerem que as "regras alternativas" (LIMA, 2011) que os agentes iam produzindo no nível da escola para lidar com limitações percebidas na política, a exemplo do material didático, eram progressivamente legitimadas pelos escalões superiores. Já em 2015, a Secretaria passava a assumir a produção de material didático dos projetos de correção de fluxo, elaborados por uma equipe constituída de professores da rede experientes nesse trabalho, que seria distribuído já no ano seguinte (2016) em algumas escolas. Com o término das parcerias, o material ia sendo substituído pelos novos cadernos criados a nível central, que mantinham uma proposta multidisciplinar de trabalho para os novos $\operatorname{projetos}^{40}$, os quais continuariam sendo regidos por um professor polivalente.

O desafio da polivalência nos anos finais foi mais uma percepção unânime por parte dos professores de projeto e de turmas regulares entrevistados. Mesmo a professora Célia, que considerava o regente único como algo que trazia mais benefícios do que prejuízos, reconhecia a dificuldade que o trabalho multidisciplinar representava para o profissional especialista. Tratava-se, mais uma vez, de uma exigência formal que perdia legitimidade aos olhos de vários agentes de nível de rua, por não a considerarem compatível com os recursos existentes, fossem eles materiais ou humanos. Nas palavras de Roger, um exprofessor de projeto, "a gente é formado no século XX, e essa proposta não está no século XX. Ela não é uma proposta de compartimentalização do conhecimento, é uma outra abordagem". Nesse sentido, embora reconhecesse como válido o viés

\footnotetext{
${ }^{40}$ Os novos projetos seriam o Acelera 6 (alunos com repetência no $4^{\circ}$ e $5^{\circ}$ ano, que fariam o $6^{\circ}$ e o $7^{\circ}$ juntos) e o Acelera 8 (alunos que chegam com distorção idade-série ao $8^{\circ}$ e fazem o $8^{\circ}$ e $9^{\circ}$ juntos). No entanto, esses projetos não foram implementados na Escola Sigma em 2016.
} 
interdisciplinar da abordagem, que previa um trabalho integrado entre as matérias, o professor não sentia que os professores tinham formação suficiente para dar conta dessas diversas áreas em que não tinham se especializado. Do reconhecimento mínimo quanto ao desafio existente - de que tampouco a capacitação formal oferecida dava conta - ao julgamento desse formato como algo "absurdo", os diferentes atores buscavam soluções alternativas.

A área de maior dificuldade variava de acordo com a especialização do professor. Quem era formado em Biologia, por exemplo, costumava ter mais facilidade com as Exatas do que com as Humanas, e vice-versa. Porém, no geral, a maior dificuldade parecia ser com a disciplina de Matemática - possivelmente porque a maioria dos professores de projeto entrevistados eram da área de Humanas. Nesse sentido, os professores relataram diversas estratégias de enfrentamento que desenvolveram, que iam desde o estudo e a pesquisa individual até a formação de redes de cooperação mútua dentro da organização. Essas redes de auxílio entre os agentes são abordadas por Licínio Lima (2011), que, fazendo uso das palavras de Michel Crozier, caracteriza a organização como

Composta de todo um conjunto de feudalidades, de redes de cumplicidade, de pequenos segredos e arranjos particulares. O seu jogo é em grande parte um jogo de proteção mútua, que só perturba muito superficialmente as intervenções de direções gerais, também muito menos racionais do que se costuma crer. (CROZIER, 1983, p. 55)

Buscando um paralelo entre o fragmento e o caso em questão, pode-se dizer que as próprias diretrizes centrais quanto à polivalência do professor no trabalho com os anos finais do Ensino Fundamental se mostravam "menos racionais" aos olhos dos professores do que deveriam ser. De fato, como apontado em Lima (2016), o argumento de que a adoção de professores generalistas favorece a aprendizagem dos alunos não encontra respaldo em pesquisas acadêmicas, ainda mais quando se trata do trabalho nos anos finais, em que os professores selecionados não têm formação em todas as áreas que lecionam. É possível também que essas diretrizes se baseassem em outro tipo de racionalidade, a exemplo de uma contenção de gastos, segundo hipótese levantada por um dos entrevistados, ou, ainda, na percepção de que esses alunos em atraso escolar não necessitavam de tanto aprofundamento, como veremos adiante.

De qualquer sorte, os agentes se articulavam entre si de um modo cooperativo, e que "protegesse" os professores de projeto de eventuais 
constrangimentos aos quais poderiam estar sujeitos diante dos alunos, caso ficasse clara sua falta de domínio sobre o conteúdo de outra disciplina a ser ensinado. A fala da ex-professora de projeto Célia ilustra uma forma de articulação nesse sentido:

Matemática a gente pedia ajuda aos colegas, entendeu? Bastante ajuda, principalmente quando chegava no $9^{\circ}$ ano, que a coisa pega mesmo, a gente pedia bastante ajuda. Aí esse menino foi um dos que me ajudou com Matemática. Ele tem que dar 40 horas, né? Aí o que que eu falei pra ele, "você pega dois tempos pra mim, no dia que você tem mais livre, e todas as dúvidas que eles tiverem, você vai explicando devagar". Quer dizer, eu também ficava sentada achando lindo. Ele era meu ajudante, e ele tinha que cumprir mais dois tempos. Então, ele dava dois tempos comigo, dois tempos com a colega. A gente nessa hora também virava aluna porque esse negócio de pentágono, diagonal e coisa... E aí ele ensinava e a gente aprendia, porque, na hora que você pega, depois você passa até com mais segurança. (Professora Célia)

Por outro lado, foi possível perceber que redes e arranjos de cumplicidade podiam ser formados também com os alunos, sobretudo quando a professora tinha uma boa relação com eles. A entrevista com um ex-aluno de projeto, que já está no Ensino Médio, indicou uma valorização por parte do próprio aluno quanto a esforços docentes desse tipo. Quando perguntamos se os professores, atuando como generalistas, conseguiam dar conta de todas as matérias, ele disse que "tem professor que consegue, sim". Em seguida, comentou sobre a professora que tinha tido, bem como sobre a outra professora de projeto que trabalhava no mesmo turno, e reforçou que ambas eram muito dedicadas aos alunos, que se interessavam e que se comunicavam para tirar dúvidas. Em todo seu relato, aparece uma forte valorização desse esforço docente, que, segundo ele, fez com que se orgulhasse e inspirasse, de modo a "correr atrás" do que não tinha entendido também, pedindo ajuda a outros professores.

As percepções dos atores quanto a essas estratégias de enfrentamento e sua eficácia varia, o que se pode relacionar com os significados que construíam em relação aos projetos. No relato dos professores e ex-professores de projeto que consideravam essas inciativas como improvisações às quais eles tinham que se sujeitar para lidar com um formato "absurdo", a percepção mais comum é que os alunos continuariam perdendo em conteúdo e ficando defasados nesse sentido. Reconheciam que não conseguiam dar o "algo a mais" e que inevitavelmente esses alunos não conseguiriam se equiparar aos regulares, podendo até ser prejudicados no futuro - seja no Ensino Médio ou no mercado de trabalho. Essa 
foi a percepção dominante por parte dos professores.

A exceção foi a professora Célia, que via essa polivalência como algo mais positivo do que negativo, para quem o "saldo final" dessas estratégias seria satisfatório. A interação com os professores no sentido de buscar ajuda, bem como os esforços individuais dos regentes em pesquisar o que não sabiam, não são apontados como insuficientes. Pelo contrário, a percepção da professora quanto ao sucesso do projeto estaria justamente na referência única para os alunos que ele proporcionava, na criação de um vínculo maior com a turma e na possibilidade de "ver" melhor os alunos. Ela considera que o trabalho foi bem-sucedido, principalmente diante de seus ex-alunos que diz estarem no Ensino Médio e até mesmo na faculdade.

Por parte da gestão, podem-se observar algumas percepções divergentes. Assim como a maioria dos professores, a diretora geral recebe criticamente o formato de polivalência nos anos finais: "Particularmente, esse sistema só quer me dizer que o seu preparo não está valendo de nada, porque se ele não tem preparo e pode dar a atividade da sua matéria, então não existe mais nada específico para a criança?" Nesse sentido, menciona que "se ler a apostila resolve, então o aluno não precisa vir para a escola", tal como pontua a professora Denise, de Inglês, para quem o professor não se forma apenas lendo o Manual. Nesse ponto, a diretora adjunta já apresenta uma visão diferente. Para ela, os professores tinham muito apoio nos cadernos, nas teleaulas e no material como um todo, que vinha bastante "mastigadinho", não constituindo grandes desafios para o trabalho com os projetos, a despeito das inúmeras críticas que ouvimos.

Embora a diretora geral tenha inicialmente apresentado uma visão crítica sobre o formato de polivalência do professor, sugerindo que os alunos poderiam perder em conteúdo ("não existe mais nada específico para a criança?”), ela apresenta uma percepção contraditória logo em seguida. Quando levantamos a hipótese de que talvez esse formato se justificasse com base na crença, por parte dos formuladores da política, de que os alunos do projeto não precisariam saber tanto, ela afirma: "E isso eu concordo. Eu não acho tão grave um professor só, porque eles não precisam conhecer a fundo nenhuma matéria, desde que eles entendam muito bem interpretação, saber redigir texto, isso é o principal para eles". Nesse sentido, não percebia o eventual enfraquecimento curricular do projeto como algo tão problemático para esses alunos, diante daquilo que 
considerava mais importante que aprendesse - bom domínio das habilidades de leitura e escrita e das quatro operações. Com base nessas expectativas, embora reconhecesse o desafio que representava para os professores a atuação como generalistas, percebia-o como algo que podia ser contornado sem grandes problemas, visto que "com boa vontade, as coisas mudam", referindo-se à ajuda mútua entre os professores.

Nesse ponto, aproxima-se em certa medida da percepção da professora Célia, para quem o saldo desse formato era positivo. Assim como a professora, a diretora concebia a referência única que o projeto proporcionava como algo benéfico às crianças que têm dificuldade, uma vez que eles tinham um olhar mais direto da professora. No entanto, para as "crianças que são muito bagunceiras, que não querem estudar", o projeto não resolveria. Na percepção dessa agente, eles atrapalhavam a turma, não conseguiam se desenvolver bem e faziam com que se gastasse tempo chamando seu responsável. Em seu relato, mais uma vez observase uma divisão dos alunos com atraso escolar entre aqueles que têm dificuldade de aprendizagem, para quem se pode fazer alguma coisa (ainda que por meio de um enxugamento curricular), e aqueles cujo problema é a disciplina e a falta de vontade de estudar, com quem acaba-se perdendo tempo. A condição desses alunos e a baixa eficácia tanto dos projetos, quanto da escola como um todo para eles é naturalizada na percepção de diversos agentes, que não aparecem implicados em seu processo de ensino-aprendizagem.

Nesse sentido, quando perguntamos à equipe gestora sobre o desempenho dos alunos egressos dos projetos que tinham sido reinseridos em turmas regulares, uma nova naturalização da repetência e do fracasso escolar é sugerida:

A de Realfa acabou, eles estão todos no $6^{\circ}$ ano. Uns bem e outros não bem, mas tão no $6^{\circ}$ ano. Bem assim... têm as dificuldades, mas vão, professor ajuda um pouquinho aqui, um pouquinho ali e eles conseguem acompanhar. Normalmente, os que estão assim, muito perdidos, acabam evadindo e indo embora da escola. Até acontece, vai pra outra escola, ou sai mesmo, não estuda mais. Mas, os que conseguem segurar até o final do ano vão. Vai chegar no final do ano, um ou outro vai repetir de ano, mas outros conseguem. (Diretora)

A fala acima diz respeito aos alunos cuja trajetória será reconstruída no capítulo seguinte, na seção 6.2. Esses alunos foram encaminhados para o projeto 
Realfabetização 1 em 2013, cursaram novamente ${ }^{41}$ o Realfabetização 1 em 2014, prosseguiram no Acelera 1 em 2015, e foram finalmente enturmados no $6^{\circ}$ ano regular em 2016. A percepção da diretora em relação a esses alunos sugere que, mesmo após todos esses anos de projeto, uns estão bem e outros não, estando vulneráveis a novas repetências e até mesmo à evasão. Essa percepção também é apresentada pela diretora adjunta quando fizemos a mesma pergunta, se os alunos estavam se saindo bem após reinseridos em turmas regulares. Segundo a gestora, "Alguns, sim, outros não. Alguns, sim, mas outros você vê que... não tem como. Mas aí faz parte do sistema, né... ele tem que ir." Como será visto no capítulo a seguir, a professora de Matemática desses alunos no $6^{\circ}$ ano percebe o risco real de fracasso por parte deles e diz que não tem mais como reprová-los, tampouco ensiná-los àquela altura (no meio do ano letivo), afirmando já ter decidido pela sua promoção para o ano seguinte.

Quanto à percepção desses agentes em relação à eficácia da política nos anos finais do Ensino Fundamental, ou seja, no prosseguimento dos estudos desses alunos no Ensino Médio após a terminalidade dessa etapa, novamente se constata uma naturalização da repetência: "Eles conseguem, pode repetir o $1^{\circ}$ ano, não estão, assim, muito aquém da expectativa não." A perspectiva de que esses alunos vão passar por uma nova experiência de repetência ecoa as constatações de Lima (2016) quanto ao elevado percentual de alunos advindos dos projetos de correção de fluxo no Ensino Fundamental que reprovam o primeiro ano do Ensino Médio, ao atingir essa etapa. Essa percepção indica, ainda, a expectativa de que alguns alunos vão repetir, contribuindo para a conclusão de que a repetência não é vista como um fracasso compartilhado com a escola, mas como um fracasso somente do aluno, compreendido como algo natural.

No entanto, não somente a repetência parece ter efeitos negativos no aprendizado e na autoestima dos alunos, como também a decisão de simplesmente promovê-los ao ano seguinte sem que tenham aprendido o que deveriam não contribui verdadeiramente para seu desempenho acadêmico. Essa decisão (sugerida na atitude da professora mencionada acima) muitas vezes reflete uma

${ }^{41}$ É importante destacar que os alunos não poderiam repetir o mesmo projeto, de acordo com a política. No entanto, como o projeto Realfabetização 1 - Se Liga (IAS) foi incorporado pela SME em 2014, tratava-se de um novo projeto, não mais realizado em parceria com o Instituto Ayrton Senna. 
atitude fatalista assumida diante desses alunos, que pode fazer com que os agentes priorizem a aceleração da passagem desses "cidadãos-usuários" pelo sistema. Nas palavras de uma professora entrevistada, "a gente espreme, espreme o máximo para esse aluno pular de série. E aí o outro professor do ano que vem é que se vire... essa é a realidade".

Essas dinâmicas e percepções sugerem que os projetos de correção de fluxo não conseguiram recuperar a aprendizagem de grande parte alunos nele inseridos. Por parte da comunidade escolar, prevalece a percepção de que esses projetos funcionavam como uma espécie de "maquiagem" por parte do sistema municipal de ensino, concentrando os alunos com menor desempenho em turmas que não faziam as avaliações nacionais e municipais. Nesse sentido, o projeto serviria ao sistema, mas não aos cidadãos-usuários do serviço público, uma vez que "quanto ao conhecimento, fica devendo, sem dúvida alguma". Cabe destacar que, na percepção do professor Roger, por exemplo, essa situação novamente adquire um caráter de intencionalidade. Em sua fala, ele reforça que, na sua opinião, "não é à toa" a decisão política de continuar deixando a educação sucateada. Dessa forma, atribui ao sistema a principal responsabilidade pelas falhas de implementação da política, que seriam praticamente previsíveis, quando se leva em conta o problema estrutural das condições de trabalho dos professores, do material fornecido e da capacitação deficitária.

Por outro lado, outros agentes "tomam para si" (pelo menos em parte) a responsabilidade de implementação dos programas. Essa percepção fica clara no relato da professora Célia, para quem "é muito fácil jogar para o outro". Segundo a professora, diversos agentes não aceitavam o projeto e o consideravam algo absurdo. No entanto, ela (re)significava a política de outra forma, como uma oportunidade de ter um tempo estendido em sala de aula com os mesmos alunos, de recuperar sua autoestima e contribuir para a continuação de seus estudos. Embora reconhecesse as falhas dos projetos, acreditava que "quem tem que mudar a coisa, é você que está ali na frente".

Este capítulo buscou mostrar um pouco de como os agentes implementadores diretos da política de correção de fluxo na Escola Sigma percebiam a proposta e seu público-alvo. Nesse processo, destacaram-se os valores predominantes que contribuem para a formação da identidade dos alunos com atraso escolar por parte dos professores e gestores. Além disso, pôde-se 
observar como os agentes percebem determinados aspectos da política, a exemplo da metodologia pedagógica prevista e do formato de polivalência do professor nos anos finais do Ensino Fundamental. Ainda, pôde-se observar de que forma eles agem sobre esses aspectos a partir de práticas discricionárias.

No capítulo seguinte, buscaremos aprofundar o estudo das percepções dos agentes implementadores sobre o público-alvo, e compreender o exercício político de sua discricionariedade na implementação dos projetos na escola, decorrente dessas percepções. As práticas discricionárias apresentadas ao longo desse capítulo se relacionarão a outros aspectos da política, como o encaminhamento de alunos e professores para os projetos e a formação de turmas na escola.

Uma vez que essas ações discricionárias estarão relacionadas a esses aspectos específicos da política como a enturmação de alunos nos projetos, terminamos este capítulo com a seção a seguir. Nela, apresentaremos uma breve análise exploratória dos dados do Censo Escolar, a partir da qual aventamos a possibilidade de que existisse uma margem de discricionariedade por parte dos agentes implementadores da política no nível da escola quanto ao encaminhamento dos alunos para essa turmas. Essa hipótese surgiu a partir da observação da forma como os dados relativos às matrículas em correção de fluxo estavam sendo preenchidos no Censo Escolar e, principalmente, ao verificarmos que determinados alunos sem distorção idade-série de dois ou mais anos constavam como matriculados nas turmas de projeto.

\section{3.}

\section{Indícios de discricionariedade com base em dados do Censo Escolar: o encaminhamento de alunos para os projetos}

Conforme mencionado no capítulo 4, para sabermos quais foram as turmas de correção de fluxo organizadas na Escola Sigma entre 2010 e 2014, trabalhamos com duas bases do Censo Escolar - a base de turmas e de matrículas - recortadas para a escola em questão ${ }^{42}$.

\footnotetext{
${ }^{42}$ Para cada ano investigado, buscamos na base de matrículas do Censo Escolar o total de alunos matriculados em correção de fluxo, de acordo com o código 23 (correspondente às turmas de correção de fluxo). Em seguida, fizemos o cotejamento dessas matrículas com a base de turmas. Nessa base, buscamos identificar quantas e quais eram as turmas de projetos de correção de fluxo organizadas na Escola Sigma a cada ano. Para tanto, comparamos os nomes dessas turmas expresso em números na base do Censo (variável "NO_Turma") com os projetos aos quais elas
} 
Ao cotejar as informações disponibilizadas nas duas bases, encontramos algumas divergências de informações. Nos anos de 2013 e 2014, por exemplo, pudemos perceber que as matrículas de algumas turmas de correção de fluxo (identificadas a partir da base de turmas), a exemplo do projeto Realfabetização 1, foram consideradas "multisseriadas" na base de matrículas. Além disso, em 2014, as matrículas dos projetos Aceleração 2 e Aceleração 3 foram preenchidas com o código relativo a turmas regulares do $6^{\circ}$ e $8^{\circ}$ anos e não como correção de fluxo.

Para além dessas incongruências nos anos de 2013 e 2014, outros fatores puderam ser observados no preenchimento dos dados entre 2010 e 2014 . Esses referem-se principalmente à inclusão de alunos nos projetos de "realfabetização" e aceleração que não apresentavam o perfil etário previsto na norma da política, ao passo que outros que tinham a distorção idade-série exigida por vezes não eram incluídos. Além disso, em alguns anos, também foi possível constatar o preenchimento de matrículas em correção de fluxo em anos escolares que não correspondiam exatamente aos anos atendidos pelo projeto realizado. Para melhor explorar esses casos, apresentamos primeiramente o quadro 3, a seguir, que focaliza apenas as turmas de Realfabetização, e posteriormente os quadros 4 e 5, que focalizam as turmas de Aceleração.

correspondiam, como indicavam as fontes oficiais. Em 2010, por exemplo, constatamos quatro turmas de correção de fluxo. O nome/número dessas turmas eram 9602, 9701, 9801 e 9802. De acordo com os documentos oficiais, as turmas 9600 correspondiam ao projeto Realfabetização 1, as turmas 9700 correspondiam ao Realfabetização 2, e as 9800 correspondiam ao Aceleração 1. 
Quadro 3: Projetos de Realfabetização desenvolvidos na Escola Sigma entre 2010 e 2014 e indícios de discricionariedade no preenchimento do Censo Escolar

\begin{tabular}{|c|c|c|c|}
\hline Ano & $\begin{array}{c}\text { Projetos de Realfabetização } \\
\text { desenvolvidos }\end{array}$ & $\begin{array}{l}\text { Caracterização segundo } \\
\text { as diretrizes formais }\end{array}$ & $\begin{array}{c}\text { Indícios de } \\
\text { discricionariedade no } \\
\text { preenchimento do } \\
\text { Censo Escolar }\end{array}$ \\
\hline \multirow[t]{2}{*}{2010} & $\begin{array}{c}\text { Realfabetização } 1 \\
\text { (Se Liga - IAS }) \\
1 \text { turma: } 15 \text { matrículas }\end{array}$ & $\begin{array}{l}\text { Alunos do } 4^{\circ} \text { e do } 5^{\circ} \text { ano } \\
\text { não alfabetizados com } \\
\text { defasagem idade-série } \\
\text { igual ou superior a dois } \\
\text { anos. } \\
\text {. Limite de } 25 \text { alunos por } \\
\text { turma. }\end{array}$ & $\begin{array}{l}3 \text { das } 15 \text { crianças } \\
\text { matriculadas no projeto } \\
\text { não tinham dois ou mais } \\
\text { anos de atraso. }\end{array}$ \\
\hline & $\begin{array}{c}\text { Realfabetização } 2 \\
\text { (Fórmula da Vitória - IAS) } \\
1 \text { turma: } 25 \text { matrículas }\end{array}$ & \begin{tabular}{l}
\multicolumn{1}{c}{ Alunos do $6^{\circ}$ ano } \\
considerados \\
alfabetizados, com ou sem \\
defasagem. \\
. Limite de 25 alunos por \\
turma.
\end{tabular} & $\begin{array}{l}\text { As } 25 \text { matrículas foram } \\
\text { preenchidas como } \\
\text { correção de fluxo no } 5^{\circ} \\
\text { ano, e não no } 6^{\circ} \text {. } \\
\text { Dos } 25 \text { alunos, apenas } 2 \\
\text { apresentavam dois ou } \\
\text { mais anos de distorção } \\
\text { idade-série. No entanto, } \\
\text { neste ano, a defasagem } \\
\text { não era um requisito } \\
\text { obrigatório. }\end{array}$ \\
\hline 2011 & $\begin{array}{c}\text { Não foram organizadas } \\
\text { turmas de Realfabetização } \\
\text { em } 2011\end{array}$ & - & - \\
\hline 2012 & $\begin{array}{l}\text { Não foram organizadas } \\
\text { turmas de Realfabetização } \\
\text { em } 2012\end{array}$ & - & - \\
\hline \multirow[t]{2}{*}{2013} & $\begin{array}{c}\text { Realfabetização } 1 \\
\text { (Se Liga }- \text { IAS }) \\
1 \text { turma: } 20 \text { matrículas }\end{array}$ & $\begin{array}{l}\text { Alunos do o } 4^{\circ} \text { e } 5^{\circ} \text { anos, } \\
\text { não alfabetizados com } \\
\text { defasagem de } 2 \text { anos ou } \\
\text { mais. } \\
\text {. Limite de } 25 \text { alunos por } \\
\text { turma. }\end{array}$ & $\begin{array}{l}\text {. As } 20 \text { matrículas foram } \\
\text { preenchidas como } \\
\text { "Multisseriadas" } \\
\text { Censo Escolar deste ano, } \\
\text { ao longo do } 3^{\circ} \text { e } 4^{\circ} \text { anos. } \\
8 \text { dos } 20 \text { alunos não } \\
\text { tinham dois anos ou mais } \\
\text { de defasagem. }\end{array}$ \\
\hline & $\begin{array}{c}\text { Realfabetização } 2 \\
\text { (Fórmula da Vitória - IAS) } \\
1 \text { turma: } 20 \text { matrículas }\end{array}$ & $\begin{array}{l}\text { Alunos do } 6^{\circ} \text { ano com } \\
\text { nível rudimentar } \\
\text { alfabetização e } \\
\text { defasagem de } 2 \text { anos ou } \\
\text { mais. } \\
\text { Limite de } 25 \text { alunos por } \\
\text { turma. }\end{array}$ & $\begin{array}{l}3 \text { dos } 20 \text { alunos não } \\
\text { tinham dois ou mais anos } \\
\text { de defasagem. }\end{array}$ \\
\hline 2014 & $\begin{array}{c}\text { Realfabetização } 1 \\
\text { (SME) } \\
1 \text { turma: } 19 \text { matrículas }\end{array}$ & $\begin{array}{l}\text { Alunos vindos do } 3^{\circ}, 4^{\circ} \text { e } \\
5^{\circ} \text { anos, ou do Se Liga - } \\
\text { "Realfabetização 1", não } \\
\text { alfabetizados, com ou sem } \\
\text { defasagem idade-série de } 2 \\
\text { anos ou mais. } \\
\text {. Limite de } 25 \text { alunos por } \\
\text { turma. }\end{array}$ & $\begin{array}{l}\text { As } 19 \text { matrículas foram } \\
\text { preenchidas como } \\
\text { "Multisseriadas" } \\
\text { Censo Escolar deste ano, } \\
\text { ao longo do } 3^{\circ} \text { e } 4^{\circ} \text { anos. }\end{array}$ \\
\hline
\end{tabular}

Fonte: Elaboração da autora, com base nos dados do Censo Escolar de 2010 a 2014, e em informações apresentadas em LIMA (2016). 
Como se pode perceber a partir do quadro acima, a incursão sobre os dados do Censo Escolar nos permitiu constatar que a inclusão de alunos que não apresentavam atraso escolar de dois anos ou mais nos projetos de Realfabetização não foi ocorreu apenas em um ano. Nesse sentido, podemos levantar a hipótese de que o principal significado atribuído ao projeto pela gestão escolar tenha sido a proposta de (re)alfabetização dos alunos, mais do que seu objetivo paralelo de correção do fluxo. Dessa forma, alunos que apresentavam maior necessidade de alfabetização, ainda que não correspondessem ao perfil etário exigido, poderiam ter sido encaminhados para as turmas. Cabe ressaltar que as constantes alterações nas normas da política, que podem ser observadas na coluna "caracterização" do quadro 2, provavelmente também contribuíram para um aumento da discricionariedade dos atores escolares.

Observa-se, ainda, que as matrículas do projeto Realfabetização 2 no ano de 2010 foram preenchidas no $5^{\circ}$ ano ao invés do $6^{\circ}$, conforme seria previsto pela política. Para além da possibilidade de erro do preenchimento, podemos mais uma vez levantar a hipótese de que a gestão tenha priorizado a matrícula nessas turmas dos alunos considerados mais necessitados para o trabalho de alfabetização, ainda que não se enquadrassem no perfil oficialmente exigido (ter cursado o $6^{\circ}$ ano em 2009).

No que diz respeito aos projetos de Aceleração desenvolvidos na Escola Sigma, novamente foi possível observar a inclusão de alunos sem a distorção idade-série prevista (de dois anos ou mais), ao passo que alunos que aparentemente apresentavam esse perfil etário não foram incluídos nos projetos. Além disso, novamente observaram-se ocorrências de preenchimento de dados do Censo Escolar que divergiam do esperado, a partir das diretrizes formais da política. Nos quadros 4 e 5, a seguir, detalhamos esses casos em cada ano. 
Quadro 4: Projetos de Aceleração desenvolvidos na Escola Sigma entre 2010 e 2012 e indícios de discricionariedade no preenchimento do Censo Escolar

\begin{tabular}{|c|c|c|c|}
\hline Ano & $\begin{array}{c}\text { Projetos de } \\
\text { Aceleração } \\
\text { desenvolvidos } \\
\end{array}$ & $\begin{array}{l}\text { Caracterização segundo } \\
\text { as diretrizes formais }\end{array}$ & $\begin{array}{c}\text { Indícios de discricionariedade } \\
\text { no preenchimento do Censo } \\
\text { Escolar } \\
\end{array}$ \\
\hline 2010 & $\begin{array}{l}\text { Aceleração } 1 \\
\text { (Acelera Brasil- } \\
\text { IAS) } \\
2 \text { turmas: } 29 \\
\text { matrículas e } 30 \\
\text { matrículas }\end{array}$ & $\begin{array}{l}\text { Alunos que cursaram o } \\
\text { Projeto Se Liga } \\
\text { ("Realfabetização 1") de } \\
\text { 2009, com defasagem. } \\
\text {. Limite de } 25 \text { alunos por } \\
\text { turma. }\end{array}$ & $\begin{array}{l}\text { As } 59 \text { matrículas foram } \\
\text { preenchidas como correção de } \\
\text { fluxo no } 8^{\circ} \text { ano, e não no } 4^{\circ} \text { ou } 5^{\circ} \\
\text { anos. } \\
23 \text { dos } 59 \text { alunos apresentavam } \\
\text { distorção idade-série de apenas } \\
\text { um ano. } \\
\text {. } 11 \text { alunos do } 4^{\circ} \text { e } 5^{\circ} \text { anos } \\
\text { regulares tinham dois ou mais } \\
\text { anos de distorção e não foram } \\
\text { incluídos em projetos de } \\
\text { aceleração. }\end{array}$ \\
\hline \multirow{3}{*}{2011} & $\begin{array}{c}\text { Aceleração } 1 \\
\text { (Acelera Brasil- } \\
\text { IAS) } \\
1 \text { turma: } 23 \\
\text { matrículas }\end{array}$ & $\begin{array}{l}\text {. Alunos que cursaram o } \\
\text { Realfabetização } 1-S e \\
\text { Liga - em 2010, com } \\
\text { defasagem idade-série, } \\
\text { alfabetizados. } \\
\text { Limite de } 25 \text { alunos por } \\
\text { turma. }\end{array}$ & $\begin{array}{l}2 \text { alunos matriculados não } \\
\text { tinham dois anos de defasagem. } \\
.40 \text { alunos matriculados no } 3^{\circ}, 4^{\circ} \\
\text { e } 5^{\circ} \text { anos regulares apresentavam } \\
\text { dois anos ou mais de defasagem e } \\
\text { não foram incluídos em projetos } \\
\text { de aceleração. }\end{array}$ \\
\hline & $\begin{array}{c}\text { Aceleração } 2 \\
\text { (Autonomia Carioca } \\
\text { - FRM) } \\
2 \text { turmas: } 26 \\
\text { matrículas e } 27 \\
\text { matrículas }\end{array}$ & $\begin{array}{l}\text { Alunos do } 6^{\circ} \text { ano } \\
\text { alfabetizados } \\
\text { defasagem de } 2 \text { anos ou } \\
\text { mais. Duração de } 2 \text { anos. } \\
\text { Limite de } 30 \text { alunos por } \\
\text { turma. }\end{array}$ & $\begin{array}{l}3 \text { alunos matriculados tinham } \\
\text { apenas } 1 \text { ano de defasagem. } \\
\cdot 4 \text { alunos do } 6^{\circ} \text { ano regular } \\
\text { apresentavam distorção de } 2 \text { anos } \\
\text { ou mais e não foram incluídos em } \\
\text { projetos de aceleração. }\end{array}$ \\
\hline & $\begin{array}{c}\text { Aceleração } 3 \\
\text { (Autonomia Carioca } \\
\text { - FRM) } \\
1 \text { turma: } 25 \\
\text { matrículas }\end{array}$ & $\begin{array}{l}\text { Alunos do } 7^{\circ} \text { ou } 8^{\circ} \text { ano } \\
\text { com defasagem idade- } \\
\text { série. } \\
\text {. Limite de } 30 \text { alunos por } \\
\text { turma. }\end{array}$ & 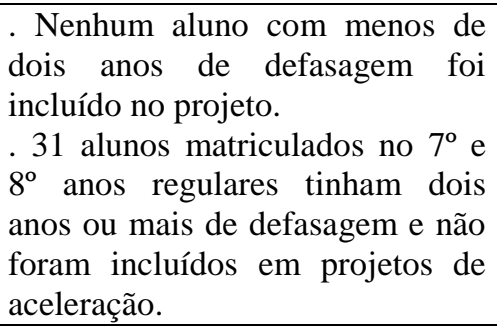 \\
\hline \multirow[t]{2}{*}{2012} & $\begin{array}{c}\text { Aceleração } 2 \text { A } \\
\text { (Autonomia Carioca } \\
\text { - FRM) } \\
1 \text { turma: } 29 \\
\text { matrículas }\end{array}$ & $\begin{array}{l}\text { Alunos do } 6^{\circ} \text { ano } \\
\text { alfabetizados } \\
\text { defasagem de } 2 \text { anos ou } \\
\text { mais. Duração de } 2 \text { anos. } \\
\text {. Limite de } 30 \text { alunos por } \\
\text { turma. }\end{array}$ & $\begin{array}{l}\text { No Censo Escolar, as } 29 \\
\text { matrículas da turma que cursava o } \\
\text { primeiro ano do projeto } \\
\text { (equivalente ao } 6^{\circ} \text { e } 7^{\circ} \text { anos) } \\
\text { foram mescladas às } 49 \text { matrículas } \\
\text { das duas turmas que cursavam o } \\
\text { segundo ano do projeto } \\
\text { (equivalente ao } 8^{\circ} \text { e } 9^{\circ} \text { anos). } \\
.76 \text { matrículas foram preenchidas } \\
\text { no } 6^{\circ} \text { ano e } 2 \text { matrículas no } 7^{\circ} \\
\text { ano. }\end{array}$ \\
\hline & $\begin{array}{c}\text { Aceleração } 2 \\
\text { (Autonomia Carioca } \\
\text { - FRM) } \\
2 \text { turmas: } 26 \\
\text { matrículas e } 23 \\
\text { matrículas } \\
\end{array}$ & $\begin{array}{l}\text { Continuidade da turma } \\
\text { do projeto Aceleração } 2 \\
\text { da FRM do ano anterior. }\end{array}$ & $\begin{array}{l}\text { Mesma observação descrita } \\
\text { acima. }\end{array}$ \\
\hline
\end{tabular}

Fonte: LIMA (2016) e Censo Escolar MEC/INEP, 2010 a 2012. 
Quadro 5: Projetos de Aceleração desenvolvidos na Escola Sigma entre 2013* e 2014 e indícios de discricionariedade no preenchimento do Censo Escolar

\begin{tabular}{|c|c|c|c|}
\hline Ano & $\begin{array}{c}\text { Projetos de } \\
\text { Aceleração } \\
\text { desenvolvidos }\end{array}$ & $\begin{array}{c}\text { Caracterização segundo } \\
\text { as diretrizes formais }\end{array}$ & $\begin{array}{c}\text { Indícios de discricionariedade } \\
\text { no preenchimento no Censo } \\
\text { Escolar }\end{array}$ \\
\hline \multirow[t]{2}{*}{2013} & $\begin{array}{c}\text { Aceleração } 1 \\
\text { (Acelera Brasil- } \\
\text { IAS) } \\
1 \text { turma: } 17 \\
\text { matrículas }\end{array}$ & $\begin{array}{l}\text { Alunos vindos do } 3^{\circ}, 4^{\circ} \\
\mathrm{e} 5^{\circ} \text { anos ou que } \\
\text { cursaram o projeto } \\
\text { Realfabetização } 1-S e \\
\text { Liga (IAS) no ano } \\
\text { anterior. } \\
\text { Limite de } 25 \text { alunos por } \\
\text { turma. }\end{array}$ & $\begin{array}{l}.4 \text { dos } 17 \text { alunos matriculados no } \\
\text { projeto tinham apenas um ano de } \\
\text { defasagem. } \\
.17 \text { alunos do } 3^{\circ} \text { e } 4^{\circ} \text { ano } \\
\text { regulares tinham dois anos ou } \\
\text { mais de defasagem e não foram } \\
\text { atendidos pelo projeto. }\end{array}$ \\
\hline & $\begin{array}{c}\text { Aceleração } 2 B \\
\text { (Autonomia Carioca } \\
\text { - FRM) } \\
1 \text { turma: } 25 \\
\text { matrículas }\end{array}$ & $\begin{array}{l}\text {. Continuidade da turma } \\
\text { do projeto Aceleração } 2 A \\
\text { da FRM do ano anterior. }\end{array}$ & $\begin{array}{l}\text { Apenas } 7 \text { dos } 25 \text { alunos } \\
\text { matriculados tinham dois anos de } \\
\text { defasagem. } \\
\text { Como essa turma é continuidade } \\
\text { da Aceleração } 2 A \text { iniciada em } \\
\text { 2012, esse índice pode sinalizar a } \\
\text { efetividade da política para esses } \\
\text { alunos, que tiveram, em grande } \\
\text { parte, sua distorção idade-série } \\
\text { reduzida. }\end{array}$ \\
\hline \multirow[t]{2}{*}{2014} & $\begin{array}{c}\text { Aceleração } 2 A \\
\text { (Autonomia Carioca } \\
\text { - FRM) } \\
2 \text { turmas: } 27 \\
\text { matrículas e } 26 \\
\text { matrículas }\end{array}$ & $\begin{array}{l}\text { Alunos do } 6^{\circ} \text { ano em } \\
2013 \text {, reprovados, com } \\
\text { baixo nível de } \\
\text { alfabetização e distorção } \\
\text { idade-série de } 2 \text { anos ou } \\
\text { mais. Duração de } 2 \text { anos. } \\
\text {. Limite de } 30 \text { alunos por } \\
\text { turma. }\end{array}$ & $\begin{array}{l}\text { As } 53 \text { matrículas das duas } \\
\text { turmas de Aceleração } 2 A \text { foram } \\
\text { preenchidas com o código } 19, \\
\text { correspondente ao } 6^{\circ} \text { ano regular. }\end{array}$ \\
\hline & $\begin{array}{c}\text { Aceleração } 3 \\
\text { (Autonomia Carioca } \\
\text { - FRM) } \\
1 \text { turma: } 25 \\
\text { matrículas }\end{array}$ & $\begin{array}{l}\text { Alunos do } 7^{\circ} \text { e } 8^{\circ} \text { ano, } \\
\text { alfabetizados } r \text { com } \\
\text { defasagem de } 2 \text { anos ou } \\
\text { mais. } \\
\text {. Limite de } 30 \text { alunos por } \\
\text { turma. }\end{array}$ & $\begin{array}{l}\text { As } 25 \text { matrículas da turma de } \\
\text { Aceleração } 3 \text { foram preenchidas } \\
\text { com o código } 21 \text {, correspondente } \\
\text { ao } 8^{\circ} \text { ano regular. }\end{array}$ \\
\hline
\end{tabular}

Fonte: LIMA (2016) e Censo Escolar MEC/INEP, 2013 e 2014.

Nota: Não incluímos a turma Nenhuma Criança a Menos em 2013, visto que ela não foi considerada como correção de fluxo pela equipe de Projetos da SME.

Um primeiro fator que chama atenção no ano de 2010 é que as 59 matrículas o projeto Aceleração 1 foram preenchidas no Censo Escolar como correção de fluxo no $8^{\circ}$ ano, ao passo que o projeto se destinava à correção de fluxo para alunos que estariam cursando o $4^{\circ}$ e $5^{\circ}$ anos. Uma hipótese explicativa para essa decisão discricionária diz respeito ao número de alunos matriculados em cada turma, vis-à-vis o que era previsto pela política. Conforme os documentos oficiais, o limite de alunos por turma estipulados pelo Instituto Ayrton Senna era de 25 alunos nos projetos dos anos iniciais, e de 30 alunos nos projetos dos anos finais. Como pode ser observado no quadro 3, as duas turmas do Acelera 1 ultrapassavam esse limite: uma tinha 29 alunos e a outra, 30 alunos. Essa 
quantidade de matrículas, embora não fosse oficialmente permitida nos anos iniciais, era admitida nos anos finais, o que pode ter levado à equipe gestora a preenchê-las no $8^{\circ}$ ano. Em 2012, novamente observa-se uma ocorrência que parece caracterizar ou um erro de preenchimento, ou uma decisão discricionária por parte da gestão escolar. As matrículas da turma iniciante no projeto Aceleração 2 naquele ano (Aceleração 2A) não se encontram discriminadas das matrículas da turma que já havia iniciado o projeto no ano anterior (Aceleração 2). A rigor, seria esperado que as 29 matrículas da nova turma fossem preenchidas como correção de fluxo no $6^{\circ}$ ano, e que as demais fossem preenchidas no $7^{\circ}$, ou até mesmo no $8^{\circ}$, visto que já teriam acelerado o $6^{\circ}$ e $7^{\circ}$ anos.

Para além dessas observações, tanto no quadro 3 quanto no quadro 4 é possível observar, mais uma vez, situações em que alunos que não tinham o perfil etário da política foram incluídos nos projetos de aceleração, ao passo que outros que tinham o atraso exigido não foram atingidos pelos projetos.

Diante do número de vezes em que esses casos apareceram na análise dos dados do Censo Escolar, elaboramos o Gráfico 2 abaixo. Nele, apresentamos os percentuais de alunos sem qualquer defasagem, com um ano de defasagem, e com dois ou mais anos de defasagem incluídos nos projetos de correção de fluxo organizados na Escola Sigma que supunham uma distorção idade-série mínima de dois anos. Dessa forma, como a distorção idade-série não era um requisito necessário para a inclusão de alunos no projeto Realfabetização 2 em 2010, as matrículas desse projeto não foram consideradas para a elaboração do gráfico neste ano.

Cabe relembrar que, no ano de 2014, as matrículas dos projetos de Aceleração foram preenchidas como turmas regulares, motivo pela qual não pudemos incluí-las na elaboração do gráfico. Neste ano, só dispúnhamos de dados referentes à turma de Realfabetização 1. No entanto, após nova mudança na política, a distorção idade-série de dois anos ou mais deixou de ser exigida para esse projeto. Dessa forma, uma vez que o projeto não mais exigia formalmente a defasagem, não incluímos o ano de 2014 no gráfico. 
Gráfico 6: Percentuais de matrículas em projetos de correção de fluxo na Escola Sigma, conforme níveis de defasagem $(2010-2013)^{43}$

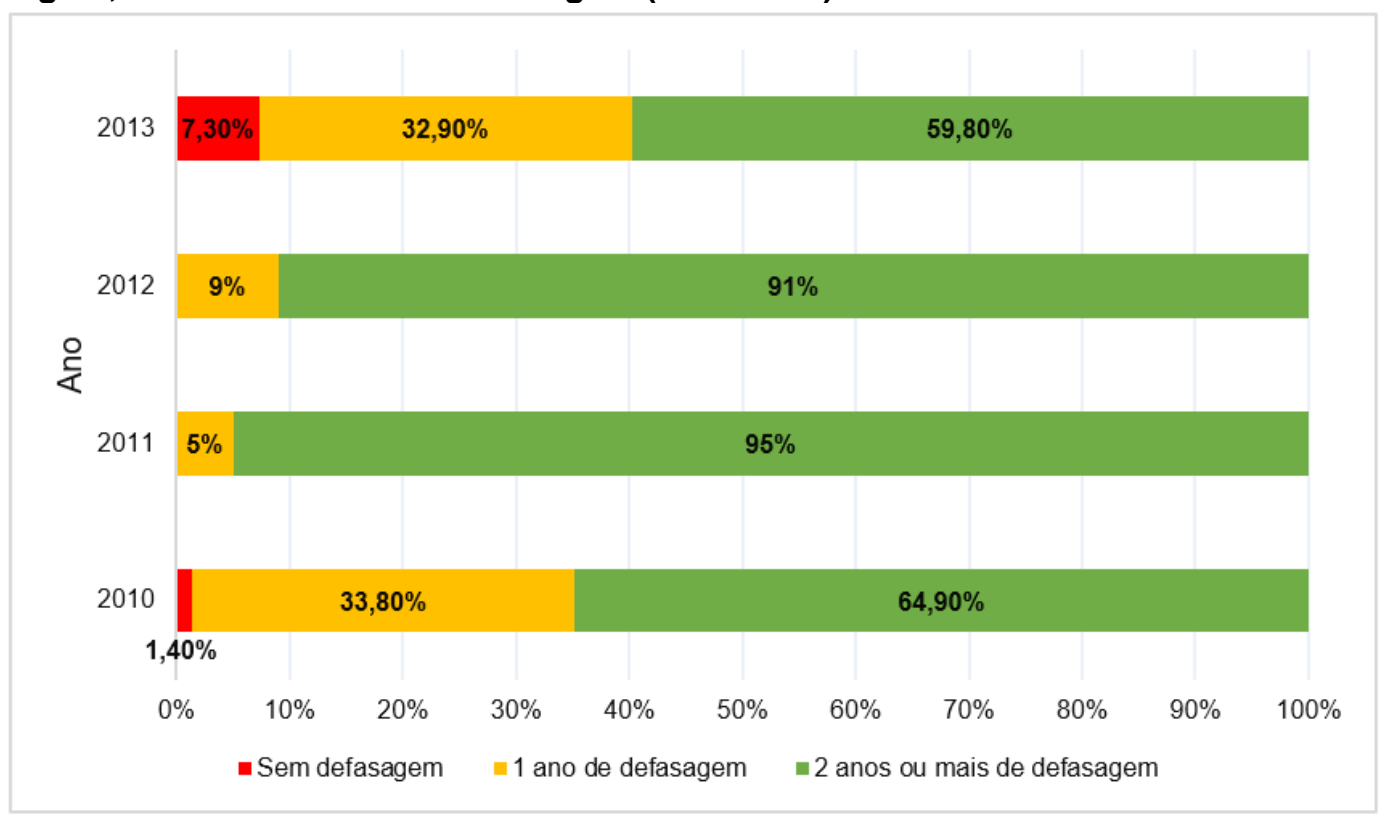

Fonte: Censo Escolar MEC/INEP, 2010 a 2013.

Como se pode perceber, não são desprezíveis os percentuais de alunos da Escola Sigma que não apresentavam distorção idade-série de dois anos ou mais e que foram incluídos em turmas de projetos de correção de fluxo previstas para alunos que tinham essa defasagem. Mesmo nos anos em que são menores (2011 e 2012), permanecem relevantes quando consideramos a quantidade de alunos que apresentavam a defasagem formalmente prevista e que não foram atingidos pelos projetos, como apresentado nos quadros 3 e 4 acima.

Esse processo de alocação dos alunos sugerido pelos dados do Censo Escolar vai de encontro à fala da diretora da Escola Sigma em sua entrevista. Quando perguntamos se havia mais defasados na escola do que conseguiam atender, se havia alguma prioridade para quem estivesse mais defasado entrar, ou se era possível organizar turma para todos, ela responde:

Aqui na escola dá. Aí às vezes a gente abre vaga para mais vizinho, para completar a turma e às vezes não dá para abrir. Como é o critério que a gente faz: é defasagem ano-série. Então eu tenho que abrir esse ano um AC2: são crianças do $6^{\circ}$ ano com mais de 14 anos. Então eu abro a turma: quem tem 15, eu boto na turma,

\footnotetext{
${ }^{43}$ Se retirarmos as 25 matrículas do Aceleração $2 B$ dos cálculos percentuais, por conta de sua peculiaridade como turma de continuação de projeto de ano anterior, na qual se espera uma redução da distorção idade-série de fato, temos novos percentuais para o ano de 2013: 73,7\% dos alunos com 2 ou mais anos de defasagem, 19,3\% com apenas 1 ano de defasagem, e 7\% sem qualquer defasagem. Ainda assim, percebem-se percentuais expressivos de alunos sem o perfil exigido pela política e que foram por ela atendidos na escola estudada.
} 
quem tem 16 anos, quem tem 14, bota; Eu posso botar os de 13 também, só que eu já completei a turma com os 30, então eu não coloco mais ninguém. Nós começamos selecionando sempre pelos maiores, os mais velhos. (Diretora geral)

O depoimento da diretora confirma sua margem de discricionariedade no encaminhamento de alunos para as turmas de projeto, ou ao menos sua percepção dela. Esse processo pode ser decorrente de diversos fatores, a exemplo da interpretação da política pelos atores. Nesse sentido, cabe lembrar que a própria política tinha dois objetivos - a correção do fluxo escolar por meio da redução da distorção idade-série, bem como a recuperação da aprendizagem (e do alfabetismo) dos alunos. Diante da quantidade relevante de alunos que foram enturmados nas turmas de projeto - sobretudo nas turmas de Realfabetização sem o perfil etário e de defasagem recomendado, pode-se levantar a hipótese de que os atores estariam priorizando justamente esse segundo objetivo da política, que diz respeito à recuperação da aprendizagem do aluno. Embora a fala da diretora tenha enfatizado que o critério principal para o encaminhamento desses alunos seria sua idade, nem sempre os dados oficiais confirmavam essa informação. No capítulo 6, poderemos perceber que surgem outras formas de racionalidade no direcionamento desses alunos aos projetos, que sugerem uma interpretação discricionária da política por parte dos agentes, bem como levam em conta sua percepção sobre o "merecimento" do aluno para ser ou não inserido nessas turmas.

É importante destacar também que o próprio dinamismo da política, expresso em uma profusão de ações que se sobrepõem, favorece essas interpretações alternativas e a margem de discricionariedade dos atores nesse processo. A cada ano, foi possível observar mudanças no desenho dos projetos, e nos grupamentos de alunos a que se destinavam. Dessa forma, nos projetos de Realfabetização, por exemplo, ora a distorção idade-série de dois ou mais anos configurava uma exigência para a entrada de alunos, ora não era mais necessária, sendo somente o nível de alfabetismo o critério oficial para a seleção desses alunos. Esse nível de alfabetismo, por sua vez, era verificado ao longo do ano anterior à entrada dos alunos nas turmas de correção de fluxo, por meio de avaliações diagnósticas (formuladas pelos organismos parceiros) aplicadas a eles. 
Outro fator que pode ter influenciado essa discricionariedade foram as mudanças $^{44}$ ocorridas na data-base para o cálculo das idades dos alunos. Como pontua Lima (2016), uma vez que as datas-bases das Portarias foram usadas como critérios pela SME para calcular a distorção idade-série e prever o encaminhamento dos alunos às turmas de projeto até 2014, essas sucessivas alterações também levaram a mudanças nas medidas de taxas de distorção idadesérie instituídas pela Secretaria.

Em suma, percebe-se que alguns dos fatores pontuados por Sabatier e Mazmanian (1979) e mencionados por Barrett (2004) - como uma falta de clareza nos objetivos das políticas e uma multiplicidade de atores e agências envolvidos em sua implementação, para além de valores intraorganizacionais - podem ter levado a diferentes interpretações e ações discricionárias na implementação da política no nível da escola. Como dito anteriormente, essas ações serão mais exploradas no capítulo a seguir quando tratarmos da percepção dos agentes sobre os principais critérios que deveriam nortear o encaminhamento de alunos para os projetos, considerando a própria percepção desses agentes sobre os diferentes alunos. Passamos, portanto, ao próximo capítulo.

\footnotetext{
${ }^{44}$ Em 2009, no primeiro ano de implementação dos projetos, a Portaria E/SUBE/CED $n^{\circ} 1$ (publicada em 12/03/2009 no D.O.) previa o último dia do mês de fevereiro como como a database em questão. No ano seguinte, em 2010, a Portaria de Matrícula (RIO DE JANEIRO, 2009e) alterou a data-base para o cálculo da idade dos alunos para o último dia do mês de junho, que foi mantido em 2011. Em 2012, no entanto, a data-base passou a 31 de março, data que permaneceu em 2013 e 2014. Em uma primeira entrevista realizada com a diretora da Escola Sigma em setembro de 2015, quando perguntamos se o mês tomado como referência para a entrada dos alunos nas turmas de projeto era o mês de março, ela responde que "era março, agora não, é até 31 de dezembro". Nesse sentido, é possível inferir que, após 2014, a SME tenha adotado o mês de dezembro como a data-base para o cálculo da idade dos alunos, em conformidade com o MEC.
} 


\section{6 \\ A relevância do ethos: atendendo aos "merecedores" "não merecedores"}

Ao longo dos capítulos anteriores, foi possível captar particularidades a respeito da Escola Sigma e de seus atores, segundo as percepções dos entrevistados. Em relação à organização, pôde-se perceber que constitui um exemplo característico de escola de enorme porte, segundo a classificação de Lima (2016), que conta com poucos recursos materiais e humanos para atender à quantidade de alunos que recebe. Nesse contexto, observa-se um processo de ressignificação da principal função da escola por parte de alguns atores, que tende a focar na dimensão socializadora/disciplinadora da instituição. Essa reformulação da missão pedagógica da escola parece ser influenciada não somente pelas dificuldades estruturais que enfrenta para a oferta de sua atividade-fim, mas também por valores e crenças dos próprios atores quanto àquilo que seus principais cidadãos-usuários (os alunos) precisam e merecem.

É nesse sentido que a percepção dos agentes sobre quem são os alunos atendidos, principalmente os alunos com atraso escolar decorrente de repetências, constitui um importante fator que para que se possa compreender a ação organizacional e as práticas discricionárias que são desenvolvidas ao longo da implementação do projeto de correção de fluxo. A percepção predominante que emerge das falas dos agentes entrevistados em relação a esses alunos, considerados desinteressados e indisciplinados, é formulada com base na forte valorização de um ethos de ascensão social pela escola, apontado por Bourdieu como um dos principais parâmetros de julgamento dos mestres. Muitos agentes fazem questão de pontuar que também estudaram a vida inteira em escola pública, e que também vieram de famílias humildes, mas distinguem-se justamente pelo esforço que eles e suas famílias fizeram para que pudessem ter uma vida melhor. Em grande parte, suas percepções ecoam o estereótipo negativo (PEREIRA, 1967) que se desenvolve em relação aos alunos. Nesse sentido, as "deficiências no terreno das responsabilidades morais", ou seja, a falta de vontade de trabalhar ou 
estudar, aparecem como a principal justificativa para as condições desses alunos e de suas famílias. Em outras palavras, a falta de dedicação desses alunos à sua vida escolar (e a pouca cobrança de suas famílias) é construída como a principal razão de seu fracasso.

Essa ênfase na moralidade condiz com a perspectiva de Maynard-Moody e Musheno (2003) quanto ao principal fator que orienta a tomada de decisões e a atitude discricionária por parte dos burocratas de nível de rua. Como mostram as diferentes histórias narradas por policiais, professores e conselheiros apresentadas na obra desses autores, esse processo envolve muito mais do que uma fidelidade normativa (LIMA, 2011) esperada por parte de um "agente do Estado". Para esses “agentes do cidadão", é a sua percepção de justiça - aquilo que consideram certo - o principal fator que orienta suas práticas concretas. Como já apresentado na seção que trata da abordagem hermenêutica-dialética, para esses trabalhadores imersos em uma vivência na linha de frente, o conceito de justiça significa responder aos cidadãos-usuários com base no seu merecimento percebido.

De acordo com Maynard-Moody e Musheno (2003), esse merecimento percebido resulta de uma espécie de uma avaliação somativa, que reflete em grande parte os valores culturais dominantes na sociedade e reproduzidos dentro da organização. Os principais fatores que, agregados, contribuiriam para que um indivíduo fosse considerado merecedor dos serviços públicos em questão seriam: necessidades genuínas, causa do problema/motivação para mudança, honestidade/caráter, e capacidade de resposta. Nas próximas seções, busca-se tratar de cada um desses elementos, relacionando-os ao contexto escolar. Além disso, procura-se mostrar de que forma essa percepção dos agentes escolares em relação ao merecimento dos alunos influencia o tipo de resposta que oferecem a eles e o esforço empreendido para atender às suas necessidades.

\section{1.}

\section{Quem é ou não merecedor? A avaliação somativa do merecimento}

Para que se possa melhor compreender a avaliação somativa do merecimento apresentada por Maynard-Moody e Musheno (2003), propõe-se o seguinte esquema gráfico: 
Figura 2: A percepção de merecimento por parte dos agentes da linha de frente

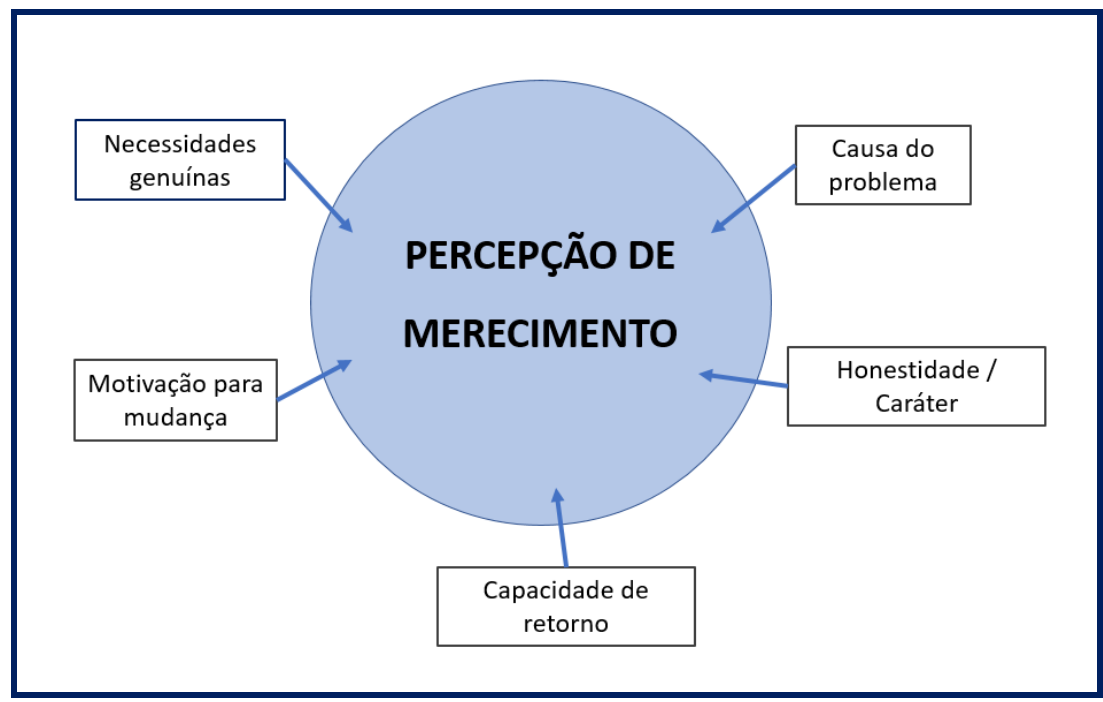

Fonte: Elaboração da autora, com base em Maynard-Moody e Musheno (2003)

A percepção dos agentes escolares quanto às necessidades genuínas dos alunos costuma ser um dos primeiros fatores a contar no seu processo de avaliação sobre como atender a suas demandas. Essas necessidades podem estar relacionadas à condição socioeconômica do indivíduo ou, no caso especificamente de escolas e políticas educacionais do gênero, ao nível de dificuldade de aprendizagem e atraso escolar que o aluno apresenta.

Necessidades genuínas não são, no entanto, suficientes para que um aluno receba algum tipo de atendimento ou atenção especial. Se os agentes da linha de frente perceberem que esse aluno tem responsabilidade sobre seu problema, ou seja, se sua forte necessidade tiver sido causada por algum comportamento errado seu, o "título de merecedor" pode não se aplicar a ele. Seria o caso, por exemplo, dos alunos que têm sua dificuldade escolar reconhecida, mas que são considerados responsáveis por ela, uma vez que "não querem nada" e que a sua má disciplina é tida como a causadora de seu mau desempenho.

No entanto, mais do que a causa do problema na percepção dos agentes, que pode apontar o próprio aluno como responsável pela sua dificuldade, a motivação que esse aluno apresenta para mudar torna-se um fator de maior peso no julgamento quanto ao seu merecimento. No trabalho ao nível da rua, segundo Maynard-Moody e Musheno (2003), motivação é compreendida como a cooperação do cidadão-usuário com o agente da linha de frente para que ele possa oferecer o serviço necessário. Nesse sentido, no caso do processo de ensino- 
aprendizagem que caracteriza o trabalho escolar, alunos motivados são aqueles que cooperam com os esforços do professor de lhe ensinar, mostrando-se assíduos e empenhados nas atividades escolares, independentemente do nível de dificuldade que tenham.

Outro fator importante a entrar na avaliação somativa dos agentes diz respeito ao caráter e à honestidade dos indivíduos a serem atendidos. Alunos considerados manipuladores, espertos ou até mesmo "trapaceiros", no sentido de que buscam "tirar vantagem do sistema" não costumam receber ajuda extraordinária por parte dos agentes implementadores. Como se verá mais à frente, podem receber menos do que um pragmatismo permitiria, ou, até mesmo, menos do lhes seria devido segundo orientações oficiais. Alunos de turmas regulares que apresentam uma distorção idade-série já suficiente para serem admitidos em turmas de projeto e que querem entrar nessas turmas a fim de acabar mais rápido a escola, mas que têm sua entrada negada, poderiam se "encaixar" de alguma forma nessa situação.

Por último, Maynard-Moody e Musheno (2003) chamam atenção para o elemento realista que envolve os julgamentos desses agentes, para além de suas considerações sobre o quanto certos cidadãos-usuários merecem um esforço extraordinário. De acordo com os autores, os critérios anteriores (necessidades genuínas, causa do problema e motivação para mudar, e honestidade/caráter) podem não ser suficientes, caso os agentes acreditem que o indivíduo a ser ajudado não tem capacidade de retorno diante do investimento a ser feito nele. Essa percepção costuma ser incorporada em enunciados como "não há mais jeito", "não há mais o que fazer", "faz parte do sistema, ele tem que sair".

Exemplos de alunos percebidos pelos agentes escolares dessa forma são aqueles que chegam aos últimos anos de Ensino Fundamental com dificuldades básicas de leitura e escrita. Ainda que os agentes não os considerem culpados por seu fracasso escolar - por vezes atribuído a problemas estruturais como o sistema de progressão em ciclos, ou à própria política de correção de fluxo considerada ineficaz - podem achar que eles "não têm mais salvação" diante do pouco tempo disponível para recuperar sua aprendizagem. Outro exemplo de aluno que costuma ser classificado dessa forma nas entrevistas com os agentes escolares é aquele que, na percepção desses agentes, são portadores de doenças cognitivas. 
Nesse sentido, seu problema de aprendizagem ultrapassaria a esfera de atuação da escola, tornando-a impotente para prestar-lhe um serviço educacional.

Para além do esforço de compreensão sobre os sentidos que esses agentes constroem em relação a esses alunos e à melhor forma de atendê-los, cabe empreender um movimento dialético de reflexão e crítica sobre suas percepções. Como tem sido tratado nos capítulos anteriores, muitas vezes precipita-se um diagnóstico de deficiência cognitiva em relação aos alunos com dificuldade escolar, assim como um "rótulo" de preguiçosos e/ou indisciplinados.

Dessa forma, a conclusão quanto à incapacidade de retorno dos alunos por conta de supostas falhas biológicas ou estruturais, que inutilizariam os esforços dos agentes escolares em relação a seu aprendizado, pode vir ser precipitada e eventualmente discriminatória. Essas percepções, por sua vez, podem acarretar na “degradação da oferta de um direito" (ALMEIDA, 2015).

Com base nesses pressupostos, o propósito deste capítulo é mostrar de que modo a percepção de merecimento dos agentes escolares em relação aos alunos impacta a ação organizacional que protagonizam. Para tanto, utilizando uma nomenclatura weberiana, propõe-se uma articulação entre as práticas realizadas pelos atores, de acordo com seus relatos, e três "tipos ideais" de serviço. Estes correspondem aos três tipos principais de resposta que esses agentes escolares oferecem aos alunos quando percebem um conflito entre os limites e as demandas da política, por um lado, e a sua percepção quanto à necessidade dos indivíduos e ao que é certo fazer, por outro. Essas três modalidades foram propostas em Maynard-Moody e Musheno (2003) e referem-se a: um serviço extraordinário àqueles considerados merecedores; um pragmatismo que busca "salvar quem se pode salvar"; e uma resposta que oferece aos indivíduos não merecedores menos do que aquilo que o pragmatismo, ou mesmo a conformidade estrita às regras, viabilizaria. Agindo dessa forma, esses agentes/atores demonstram que, mais do que executores, são fazedores de regras e políticas. A decisão de quando agir de uma forma ou de outra tem implicações consideráveis, tanto para a organização, quanto para a sociedade como um todo. Nas palavras dos autores:

Quando os trabalhadores da linha de frente ampliam ou retêm serviços e sanções, quando saem de seu caminho para ajudar alguns cidadãos-clientes enquanto ignoram ou punem outros, eles estão fazendo julgamentos normativos sobre quem recebe o quê do governo: eles estão simultaneamente fundindo a performance do 
Estado com a construção da ordem social. (MAYNARD-MOODY e MUSHENO, 2003, p. 106) $)^{45}$

Em seguida, passamos à análise de práticas similares na escola estudada.

\section{2. \\ Mais do que o pragmatismo: um serviço extraordinário para os merecedores}

Tinha uma aluna chamada Jéssica [nome fictício], que não fez o $5^{\circ}$ ano, ela pulou do $4^{\circ}$ pro $6^{\circ}$. Ela já tinha feito antes, quando não conseguia ser alfabetizada, um projeto. Aí do $4^{\circ}$ jogaram pro $6^{\circ}$. Quando chegou no $6^{\circ}$, eu falei com a [nome da pessoa], que era a administradora do projeto, que eu queria passar ela pro projeto. Ela me perguntou "por quê?" Eu falei "porque, se você deixar, ela não vai conseguir, ela pulou o $5^{\circ}$ ano!" Aí botei ela no projeto. Aí o que acontece, ficou lá, a primeira reunião que teve de projeto, tipo maio, falaram que ela não podia ficar porque ela não tinha mais de 14 anos, aí ela voltou pro $6^{\circ}$ ano. Então o que eu fazia com ela? Ela estudava de manhã, quando ela acabava, ela subia - porque eu tava lá em cima na sala de projeto - e tudo que ela tinha dado naquele dia a gente conversava. [...] Por exemplo, hoje ela tinha Português, Matemática, Ciências e História. Ela não ia embora, ficava comigo até 13h lá em cima, "Qual a dúvida? O que você não entendeu?" Aí depois ela ia pra casa. E foi até o final do ano. Aí no final do ano, ela passou o $6^{\circ}$ e iria fazer o $7^{\circ}$, aí ela foi pro projeto. Fez o $8^{\circ}$ e $9^{\circ}$. E hoje já foi, já tá fazendo o $2^{\circ}$ grau. (Professora Célia)

Ao contrário de uma perspectiva que reduz o exercício da discricionariedade à busca dos atores pela satisfação dos próprios interesses, algumas histórias sugerem que os agentes da linha de frente tornaram seu trabalho mais difícil para responder às necessidades dos indivíduos que consideram dignos desses esforços. Ajudar um usuário (no caso, um aluno) pode significar batalhar contra um sistema burocrático considerado limitante, o que nem sempre se pode fazer por todos. Diante de dificuldades políticas, de tempo, e de cooperação por parte de outros agentes necessários, esforços extraordinários desse tipo acabam reservados aos poucos merecedores. Nessas situações, o agente atua como uma espécie de advogado desse cidadão escolhido, assumindo um trabalho que pode ser prolongado e desgastante com o "sistema".

\footnotetext{
45“"When street-level workers extend or withhold services and sanctions, when they go out of their way to help some citizen-clients while ignoring or punishing others, then street-level workers are making normative judgments about who gets what from government: they are simultaneously fusing the performance of the state with the construction of the social order." (MAYNARDMOODY e MUSHENO, 2003, p. 106)
} 
A ex-professora de projeto Célia narra um evento que parece se encaixar nesse "tipo ideal" de prática. Ela tinha uma aluna que já havia sido enturmada em turmas de projeto nos anos iniciais, segundo a professora, por dificuldades na alfabetização. Ao final desse projeto, ela foi encaminhada para $6^{\circ}$ ano, tendo pulado o $5^{\circ}$ em decorrência da aceleração prevista pela política. Quando chegou ao $6^{\circ}$ ano, a professora percebeu que ela ainda estava com muita dificuldade, arriscando repetir de ano. Pode-se perceber já nesse início da narrativa que, embora o projeto de que a aluna havia participado nos anos iniciais tivesse corrigido sua defasagem de idade, ele não parecia ter solucionado por completo seu atraso escolar, a ponto de estar vulnerável a uma nova repetência, aos olhos da professora.

Embora a aluna não fosse elegível para ser incluída novamente em um projeto de aceleração (agora nos anos finais), porque não tinha mais a distorção idade-série oficialmente exigida, a professora recorreu à administradora dos projetos no escalão superior para "advogar" pela aluna, buscando sua inclusão no projeto. Nesse momento, percebe-se que o principal sentido que a professora Célia atribuía à política de correção de fluxo - da qual ela participava como implementadora direta, ao reger essas turmas - era a recuperação da aprendizagem do aluno com dificuldade escolar. Mesmo que a aluna Jéssica estivesse na série correspondente à sua idade (após ter passado por um projeto de aceleração), ela permanecia com dificuldade de aprendizagem. Nesse sentido, julgou que ela se beneficiaria do trabalho com os projetos, que poderiam dar a ela esse suporte.

Inicialmente, seus esforços pareciam ter surtido efeito, e a menina conseguiu ser encaminhada para a turma. Contudo, em uma reunião posterior, houve um retrocesso na decisão inicial por conta da idade da aluna, que não a tornava elegível para o projeto, segundo a política. Mesmo diante do insucesso dessa tentativa inicial de estender informalmente os critérios de elegibilidade da política para uma aluna que julgava necessitada, a professora não esgotou seus esforços. $\mathrm{Na}$ realidade, acabou por oferecer um serviço diferenciado, que consistia em um reforço escolar individualizado ao final de suas aulas, ao longo de todo o ano. Ao contar mais a respeito da aluna, percebe-se que, para além da grande necessidade de ajuda que apresentava, outros fatores pareciam ser relevantes para o julgamento final que a professora realizara. Em suas palavras, a aluna 
Era, assim, uma pessoa, uma aluna maravilhosa. Mas faltava tudo. O pai dela era aqui do [nome de um supermercado próximo à escola], então vira e mexe ele tava aqui, "como é que tá?" E aí ela voltou e eu falei "que absurdo essa menina voltar pra sala de aula comum!" Porque é toda uma regressão, né? Aí ela voltou, mas aí o que eu fiz? O acompanhamento dela até o final do ano. (Professora Célia)

Pode-se perceber, pelo seu relato, que a aluna é retratada como necessitada não só em termos de aprendizagem escolar, mas também em outras esferas possivelmente a material ("faltava tudo"). A maneira como é descrita aponta, ainda, para uma desresponsabilização diante de sua condição. $O$ que possivelmente levou à sua dificuldade escolar foi sua condição externa (caracterizada pela carência) e/ou uma falha do próprio sistema, que "jogou ela pro $6^{\circ}$ " sem ter feito o $5^{\circ}$ e a colocou em sala de aula comum - um "absurdo" nas palavras da professora. Para além disso, sua família é percebida como presente, atuante, e interessada no desempenho escolar da filha. Como visto anteriormente, os agentes escolares atribuem bastante importância à relação família/escola, valorizando muito o esforço e interesse tanto do aluno, quanto de sua família. A aluna pareceu ter mostrado, ainda, motivação ao se engajar nas atividades propostas pela professora, tendo cooperado com sua aprendizagem ao longo de todo o ano, ficando um pouco mais de tempo na escola. Aqui, novamente, aparece a relevância de um ethos de dedicação à escola, apresentado por Bourdieu e tratado ao longo do trabalho.

Dessa forma, a construção identitária da aluna segundo a percepção docente enfatizava sua necessidade genuína, a externalidade da causa de seu problema e sua motivação para cooperar com a escola, e seu bom caráter ("uma aluna maravilhosa"). Diante desses elementos, possivelmente a professora avaliou como positiva sua capacidade de retorno aos esforços extras a serem feitos, o que teria se confirmado com sua formatura e prosseguimento dos estudos em nível médio.

É importante notar que, ao se esforçar para que a aluna considerada "merecedora" fosse incluída em uma turma de projeto, a professora implicitamente considera que o trabalho realizado nas turmas de correção de fluxo é bom, e pode contribuir positivamente para o aprendizado da aluna. De fato, pôde-se perceber em todo seu relato uma visão bastante otimista e confiante em relação aos projetos e à ajuda que ofereciam aos alunos, apesar das dificuldades existentes. Contudo, a percepção contrária é bastante recorrente, tendo se mostrado, na realidade, dominante nas demais entrevistas. O próximo relato 
ilustra como a maneira de significar a política impacta as ações discricionárias no sentido de ajudar àqueles considerados dignos para tanto.

Durante a entrevista com a diretora da Escola Sigma, perguntamos como se dava o encaminhamento dos alunos para as turmas de correção de fluxo. De início, ela foi bastante enfática em afirmar: "Não é a gente que escolhe. É a regra. São 2 anos de defasagem". Contudo, em seguida, ela apresenta um adendo:

Incluindo com isso também o aproveitamento da criança, às vezes o aluno pode ser indicado pra um projeto por causa da idade, mas tá muito bem alfabetizado, foi algum um outro problema de percurso lá que... Teve um aqui que já era mais velho, mas ele só começou a estudar muito tarde. Então, ele não tinha perfil de projeto, só tava com mais idade porque aconteceu alguma coisa lá no início, aí a gente pode tirar do projeto. [Entrevistadora: Porque ele não se beneficiaria do projeto?] Não vale a pena, o garoto tava bem, só que ele começou a estudar dois anos mais tarde. Mas, ele acompanhava, tava bem, então não havia necessidade. Mas, sem conhecer ninguém, a regra é 2 anos de defasagem. (Diretora)

A partir de seu relato, pode-se perceber uma ressignificação da política sob a ótica da diretora. Ainda que, formalmente, o critério que orientava a enturmação desses alunos em turmas de projeto fosse exclusivamente baseado em sua distorção idade-série, a agente apresenta outra compreensão acerca de que tipo de aluno tem perfil para ser atendido pela política, o que influencia diretamente suas práticas discricionárias. Ao dizer que não valia a pena incluir o aluno no projeto uma vez que ele estava muito bem alfabetizado e que ia bem na escola, pode-se inferir uma crença implícita na adequação dos projetos àqueles que tem um baixo aproveitamento nas turmas regulares. Nesse sentido, o projeto poderia eventualmente vir a prejudicar o aluno mais velho em questão. Esse aluno "merecedor" é apresentado em sua narrativa como um bom aluno que não tinha responsabilidade sobre seu atraso escolar, o qual seria fruto de uma entrada tardia no sistema e não, por exemplo, de repetências. Dessa forma, a agente decide de certa forma "poupá-lo" dessa trajetória, usando de uma margem de liberdade percebida ("aí a gente pode tirar do projeto"), que não necessariamente corresponde ao discurso oficial da política.

Essa prática discricionária relativa ao encaminhamento de alunos para os projetos segundo o critério da dificuldade de aprendizagem também foi percebida por meio de um relato breve da atual professora de projeto dos anos finais, Sabrina, em sua entrevista. Quando perguntamos se ela percebia muitos alunos fora da faixa etária recomendada nos projetos, ela citou apenas um caso antigo, "lá em 2011", em que havia um menino muito novo na sua turma que tinha 
dificuldade de aprendizagem por conta de problemas de saúde que havia tido a vida inteira. Diante disso, "apesar de ele ser novo, acharam por bem colocá-lo numa turma de projeto". Logo em seguida, afirmou haver diversos tipos de alunos de projeto: alunos com "dificuldade de aprendizagem, deficiência cognitiva, e desinteresse mesmo", fatores que às vezes se combinavam.

Diante do perfil percebido dos alunos que compunham essas turmas (com dificuldade, com deficiência, e desinteressados), cabe refletir quanto à racionalidade que sustentava o encaminhamento de alunos como esse menino mais novo para o projeto. Seu direcionamento para essa turma sem o perfil etário formalmente exigido constituiria um esforço extraordinário por parte dos agentes escolares, no sentido de lhe oferecer uma melhor chance de aprendizagem? Seria baseado em uma perspectiva pragmática quanto aos limites do que pode ser feito por ele diante de seus problemas de saúde, levando à conclusão de que era melhor "acelerar" sua passagem pelo sistema? Ou, ainda, estariam esses dois sentidos concorrendo para essa decisão? Embora não tenha havido oportunidade de explorar esse caso com maior profundidade, ele pode contribuir para a percepção de que havia outros critérios alternativos na organização, para além da regra formal da faixa etária, que se mostravam relevantes no encaminhamento de alunos para essas turmas.

As histórias narradas pelos agentes acima os apresentam como dispostos a contrariar regras formais e produzir regras alternativas, ou até mesmo tornar seu trabalho mais difícil ou desgastante em benefício daqueles que consideram dignos de tais esforços. Contudo, trata-se de iniciativas que dificilmente conseguem se estender a todos. Na maior parte dos casos, os agentes buscam substituir o idealismo pelo pragmatismo, ou seja, por aquilo que percebem que podem fazer diante de tantas limitações e dificuldades que o dia a dia em uma escola pública municipal do tamanho e complexidade da Escola Sigma apresenta. A seguir, apresentamos uma análise de determinadas práticas reconstruídas pelos entrevistados em seus relatos que correspondem, em certa medida, a esse segundo "tipo ideal" de serviço. 


\section{3. Pragmatismo: fazendo o que (percebe-se que) pode ser feito}

Na seção dedicada à explicação da abordagem hermenêutica-dialética, apontou-se a relevância da categoria de senso comum, compreendido como um saber prático-moral, e do conceito de vivência para análise do trabalho da linha de frente. Como dito anteriormente, os agentes do nível da rua se apresentam como pragmáticos e realistas, ainda que muitas vezes tenham começado seu trabalho como idealistas:

Muitos trabalhadores da linha de frente entraram nas suas profissões como idealistas. Após anos de sobrecarga, clientes que não cooperam, um público indiferente, e condições de trabalho dilapidadas, às vezes espantosas, eles ainda precisam preservar algum sentido e valor para o seu trabalho. Muitos usam sua discricionariedade para selecionar um pequeno número de casos ou membros do público para tratamento especial, o tipo de tratamento que eles possivelmente ofereceriam a todos, se tivessem recursos e energia. (MAYNARD-MOODY e MUSHENO, 2003, p. 12) (6) $^{46}$

Esses trabalhadores se orgulham de seu pragmatismo, adquirido após diversas experiências desgastantes e até mesmo frustrantes, como pontuado acima. Esses agentes dão valor ao conhecimento que possuem da realidade em que trabalham e à sua capacidade de decidir com propriedade o que deve ser feito nesse contexto. Esses saberes e habilidades são valorizados de tal forma por esses agentes, que podem apresentar certa desconfiança em relação ao conhecimento e avaliações dos elaboradores de política, dos agentes dos órgãos centrais, e de intelectuais ou pesquisadores - todos afastados do nível da rua (o "chão da escola", no caso desta pesquisa). Em outras palavras, quem está na linha de frente saberia mais e melhor o que funciona e o que não funciona, o que pode ou não ser feito, e a quem se pode ou não ajudar.

Esses julgamentos e iniciativas, por sua vez, impactam diretamente os indivíduos a serem "salvos ou não" e, de certa forma, a sociedade como um todo. Nas interações entre os agentes e os cidadãos-usuários e nas práticas concretas da organização, portanto, reproduzem-se, produzem-se ou reforçam-se valores e

\footnotetext{
46 "Many street-level workers entered their professions as idealists. After years of overload, uncooperative clients, an indifferent public, and dilapidated, sometimes dreadful, working conditions, they still need to preserve some meaning and value for their work. Many use their discretion to select a small number of cases or members of the public for special treatment, the kind of treatment they might provide all citizen-clients if they had the resources and energy." (MAYNARD-MOODY e MUSHENO, 2003, p.12)
} 
crenças sociais. Diante disso, propõe-se um movimento duplo nesta seção: um esforço hermenêutico de compreensão do sentido que esses agentes atribuem a suas práticas - muitas vezes apresentado como uma escolha pragmática de "salvar a quem se pode salvar" - e um movimento dialético de crítica a esse sentido - que por vezes pode ser reelaborado como uma escolha moral de "salvar a quem merece ser salvo".

O relato das duas professoras de inglês entrevistadas - a Professora Olívia, que trabalhava com a turma de projeto remanescente em 2016, e a professora Denise, que havia trabalhado com turma de projeto anteriormente - apresentam-se como exemplos em que o idealismo dá lugar ao pragmatismo, na percepção das agentes. Em suas narrativas, as agentes constroem histórias de esforços que foram retribuídos com indiferença por parte dos alunos. Consequentemente, relatam que acabam por selecionar alguns casos para dedicar um empenho maior - aqueles alunos que seriam capazes de oferecer retorno ao seu investimento. Esses, por sua vez, tendiam a ser os alunos das turmas regulares. Para que se possa melhor compreender seus relatos, cabe reconstruir um pouco do contexto que dizia respeito ao lugar que pareciam ocupar as aulas de inglês nas turmas de projeto.

O elevado nível de absenteísmo dos alunos das turmas de projeto foi uma percepção predominante por parte dos agentes escolares, além de ser algo "confessado" por alguns alunos entrevistados. $\mathrm{O}$ índice de faltas parecia ser ainda maior às quartas-feiras, no dia de blocagem, quando os alunos tinham disciplinas como Inglês, Artes/Música e Educação Física com outros professores, que não o professor regente da turma nos outros dias da semana. As duas professoras de Inglês entrevistadas que trabalharam/trabalhavam com os projetos relataram que os alunos faltavam muito. A professora Denise afirma, ainda, que a professora regente da turma pedia a ela que não lançasse faltas, pois isso prejudicaria o lançamento dessa professora. Diante disso, Denise conta que só lançava conteúdo no sistema, e acabava tendo que dar presença para todos, sem sequer saber quem só vinha à aula de Inglês, ou quem só não vinha à sua aula. Segundo ela, também não era possível avaliar a postura dos alunos com a outra professora, uma vez que elas raramente se encontravam (quando muito, nos conselhos de classe). Trata-se de uma situação que pode ser interpretada como mais um indicativo da articulação débil e pouca colaboração entre docentes existente na escola. 
A professora Denise caracteriza sua experiência no Acelera como muito negativa, sendo algo que jamais repetiria. Segundo seu relato, o desinteresse dos alunos era total em relação à sua disciplina, além de serem muito hostis com ela. Como forma de compreender esse fenômeno, ela pontua vários fatores agravantes: sua matéria teria pouca conexão com a realidade social do alunado; era ministrada por outra professora que não aquela com quem eles vinham criando um vínculo ao longo de todos os dias da semana; no dia em que tinham aula de Inglês a professora da turma não se encontrava na escola; e este era considerado o "dia de lazer", quando tinham Educação Física e Artes/Música. Assim, as faltas neste dia pareciam ser bem mais altas, e os alunos que vinham, segundo ela, vinham por conta da aula de Educação Física, e muitas vezes não iam às suas aulas. Dentre as estratégias que mencionou usar para despertar interesse por parte dos alunos, estava o trabalho com músicas e vídeos. Contudo, ela conta que esbarrava na limitação de recursos existentes para realizar essas dinâmicas, e que muitos alunos não gostavam das músicas que traziam porque não eram aquelas que costumavam ouvir. Em suma, na percepção da agente, "NADA que trouxesse provocava nenhum tipo de interesse".

A professora Olívia apresentou percepção semelhante quanto ao desinteresse e às faltas. Segundo ela, as agentes educadoras e as diretoras às vezes tinham que ficar "catando os alunos" que vinham no dia, e que se escondiam pela escola para matar aula. Por vezes, dava aula para cerca de seis alunos, ou dez alunos numa turma maior. Diante dessa situação, buscava fazer avaliações contínuas que valessem ponto para estimular a frequência dos alunos. Nesse sentido, pode-se perceber que a estratégia usada girava em torno de recompensas ou punições (ganhar ou perder pontos). No entanto, na sua percepção, nem mesmo esse tipo de estratégia parecia surtir o efeito esperado.

No que diz respeito ao alto índice de absenteísmo dos alunos dos projetos no dia da aula de inglês, vale mencionar o relato de uma aluna de projeto entrevistada. Seu relato sugere que ela mesma, enquanto aluna, parecia usufruir de uma espécie de discricionariedade quanto ao comparecimento nas aulas de língua estrangeira. Primeiramente, tanto ela quanto um outro aluno entrevistado afirmaram que faltavam muito às aulas, tanto nas quartas quando nos outros dias. $\mathrm{O}$ aluno afirma que parou de faltar quando percebeu que podia ser reprovado por falta. Nesse momento, outro aluno interrompeu a entrevista para dizer que, se 
faltassem muito, podiam perder o bolsa família. Até aí, pode-se perceber que o principal estímulo para o comparecimento era a eventual punição que poderiam receber do sistema (a reprovação ou a perda do auxílio governamental). São relatos que sugerem em alguma medida que a racionalidade que embasava a estratégia da professora mencionada acima (as avaliações valendo ponto) fazia sentido dentro dessa lógica de frequência estimulada por risco de punição.

Já a aluna parou de faltar porque seu pai descobriu que ela não estava indo à escola e, depois de conversar com a professora, passou a deixá-la na porta todos os dias. Contudo, ela afirma que continuava faltando às quartas-feiras, dia em que tinha aulas de Inglês, Artes e Educação Física. Em sua retórica de justificativa, afirma que a professora de Inglês estava de licença e que só tinham Educação Física e Artes. Como não gostava de Educação Física, e Artes, na sua percepção, era de alguma forma contemplada pela sua professora regente em sala de aula, "não tinha porque vir", até porque eles saíam mais cedo por conta da professora que estava de licença. No entanto, na realidade quem estava de licença era a professora de Artes, e eles estavam tendo Educação Física e Inglês normalmente. Mais à frente em sua entrevista, ela afirma que fazia curso de inglês de manhã, no mesmo dia em que teria aula da escola (quarta-feira) e que, por isso, para ela não fazia tanta falta. Quando perguntamos se ela não ficava prejudicada nas avaliações, disse que não estava com nota baixa em Educação Física.

Esses relatos sugerem alguma espécie de articulação interna dentro da organização e/ou prevista pela própria política no sentido de não atribuir a mesma importância à participação desses alunos nas atividades do dia da blocagem como ocorria nos demais dias. Inclusive, a professora Denise traz um questionamento nesse sentido ao final de sua entrevista:

A única coisa que eu digo é esse questionamento: será que é momento pra ter aula
de inglês? O momento de um trabalho com o Acelera? O Acelera é justamente pra
recuperar coisas que ficaram pra trás. Seja por dificuldade, baixa autoestima, achar
que não é capaz de aprender, se precisaria desse tempo para que eles conseguissem
recuperar o que ficou pra trás, e já estão atrasados mesmo. Eu não consigo
visualizar a aprendizagem de uma língua estrangeira nesse momento, por todos os
fatores. Toda vez que eu falo isso, alguém diz assim "não, mas eles têm o
direito...". Tá, têm o direito, claro, mas talvez não seja ESSE momento. É a única
coisa que eu tenho pra dizer, que eu acho que não é esse momento. EU acho que
não é esse momento. (Professora Denise - ênfases da entrevistada) A forma como a professora constrói sua fala sugere que o direito desses alunos de terem aulas de inglês, embora reconhecido por ela, se apresenta como 
algo ideal, aparentemente inatingível aos seus olhos. Nesse sentido, há uma pergunta implícita no seu relato: O que seria idealmente necessário para esses alunos e o que é pragmaticamente possível fazer dentro dos constrangimentos impostos pelo contexto de implementação da política (tempo de duração, espaço, público-alvo atendido etc)? A resposta que apresenta aponta para impossibilidade de ensinar inglês para os alunos inseridos nos projetos de aceleração diante de tantos fatores limitantes percebidos. Em sua retórica de justificativa à crença de que esse não é o momento para esses alunos terem aulas de inglês, a professora alega que eles precisam desse tempo para "recuperar coisas que ficaram para trás". Dentre essas coisas a serem recuperadas ou aprendidas, a princípio não consta o aprendizado de uma língua estrangeira.

A professora Olívia, por sua vez, já havia trabalhado com turmas de projeto (Aceleração 1) e agora trabalhava com a turma de Aceleração 2. Seu relato sobre o material didático de língua inglesa que decidiu usar com os alunos da turma de projeto também sugere que, em sua ótica, um pragmatismo se mostrou mais razoável após frustrações sofridas diante de um público considerado indiferente e não cooperativo. Em suas palavras:

Eu peguei o Acelera 1. Aí eu peguei um livro que, na época, os professores estavam adotando no $6^{\circ}$ ano pra usar. Só que eles tinham um descaso com o material, entendeu? Eles não cuidavam bem do material, o material ficava jogado na sala. A gente nem deixava eles levarem pra casa, porque se levar pra casa, não volta, né... então aí esse ano eu falei "não vou adotar material, não", até porque ainda não chegou no colégio. Ou então chegou uma quantidade pequena, que eu falei assim "não vou desfalcar outras turmas e vou dar... usar material às vezes numa turma que não vai, né, assim... não vai ter o retorno que outra turma teria". (Professora Olívia)

O material a que a professora se refere era produzido por um curso de idiomas através de uma parceria público-privada com a Secretaria Municipal de Educação. A professora considera o material de muito boa qualidade, embora reconheça que algumas dinâmicas propostas não podiam ser realizadas no contexto de uma escola pública. Inicialmente, ela deixa explícito que optou por usar o mesmo material das turmas regulares com as turmas de projeto, "para dar uma ideia de igualdade maior". Contudo, diante do descaso com o material que percebia por parte dos alunos, decidiu reservar esses livros, bem como o direito de levá-los para casa, àqueles alunos que ofereciam um retorno maior. Ainda que idealmente quisesse oferecer o mesmo para todos, a escolha pragmática se mostrou mais razoável aos seus olhos. 
Primeiramente, tomando como base as narrativas construídas por essas agentes, é importante realizar um esforço empático e compreender suas frustrações e as razões que as levaram a fazer escolhas relativas à elegibilidade dos alunos no acesso a benefícios (o material didático de qualidade, ou o próprio ensino de inglês) ou sanções (a impossibilidade de levar o material para casa). Contudo, é também possível refletir quanto à possibilidade de que aquilo que descrevem como escolhas pragmáticas impliquem também decisões morais.

No que diz respeito a necessidades genuínas, por exemplo, o discurso da professora Denise sugere que o aprendizado de língua inglesa não seria percebido como uma necessidade prioritária ou urgente para os alunos das turmas de projeto. No que diz respeito à motivação por parte dos alunos, ambas as professoras descrevem os alunos de projetos como pouco cooperativos com seu processo de ensino-aprendizagem de inglês, o que se traduzia, por exemplo, no alto índice de absenteísmo. Quanto à capacidade de retorno, a percepção da professora Olívia quanto ao descaso que os alunos apresentavam com o material que oferecia a eles foi tomado como um indício do baixo retorno que esses alunos poderiam dar aos investimentos feitos. Esses elementos poderiam concorrer para que a percepção de merecimento desses alunos se tornasse baixa quando comparado a outros alunos. Essa avaliação, por sua vez, poderia orientar as decisões discricionárias tomadas por essas agentes.

Outro caso apresentado por diversos agentes como uma decisão pragmática, aqui problematizada como uma decisão moral, diz respeito ao agrupamento dos alunos oriundos de turmas de projeto no primeiro segmento em uma mesma turma homogênea no $6^{\circ}$ ano, após a conclusão desses projetos. Antes de analisar especificamente esse caso, cabe tratar brevemente de algumas pesquisas que se debruçam sobre a composição de turmas homogêneas no interior das escolas, e seus possíveis efeitos.

Em seu capítulo dedicado às turmas homogêneas, Lima (2016) apresenta uma breve discussão de pesquisas internacionais e nacionais que focalizam os pressupostos e os efeitos da organização dessas turmas. A principal razão pela qual a autora propôs essa discussão está no fato de que a organização de turmas homogêneas - por defasagem idade-série e, implicitamente, dificuldades de aprendizagem - é uma das principais características estruturantes dos projetos de correção de fluxo. No caso desta seção, não se propõe analisar essa prática 
somente como uma característica da política em si, mas principalmente da escola estudada, que parece apresentar uma racionalidade na organização de turmas regulares semelhante àquela que orienta a organização das turmas de projeto, muito embora apresente críticas a esse formato.

Como pontuado pela autora, os sistemas estaduais e municipais de ensino no país desfrutam de autonomia para a produção de normas relativas à composição de turmas, com base em critérios comumente estipulados pelas secretarias de educação. No entanto, é comum encontrar uma observância de aspectos genéricos dessas orientações, sendo as escolas as principais responsáveis pela definição de critérios mais particulares que orientem a distribuição e enturmação dos alunos. Nesse sentido, observa-se uma predominância de critérios como rendimento, disciplina ou idade na organização de turmas, com a prevalência dos dois primeiros (que costumam caminhar juntos) em muitos casos.

A motivação comumente alegada para esses arranjos, por parte dos agentes escolares, diz respeito à maior facilidade que as turmas homogêneas apresentam para que se desenvolva um trabalho pedagógico mais bem direcionado às necessidades da maioria dos alunos. Essas turmas permitiriam, portanto, um trabalho mais eficaz tanto para aqueles com os alunos com mais dificuldade, quanto para aqueles que têm melhor desempenho. Nas entrevistas realizadas com as agentes da Escola Sigma, também puderam-se perceber crenças desse tipo. Uma professora generalista, por exemplo, se questiona como, em uma turma de $3^{\circ}$ ano lotada, o professor conseguiria trabalhar com uma parte que sabe ler e escrever muito bem, um outro grupo que está caminhando, e outro que sequer reconhece as letras do alfabeto.

No entanto, pesquisas que se dedicam à análise dos efeitos desse tipo de composição de turmas revelam problemas relacionados ao aprofundamento das desigualdades no interior da escola, como o agravamento da situação dos alunos em dificuldade escolar e a potencialização do risco de estigmatização desses grupos. Crahay (2007) problematiza os benefícios pedagógicos pressupostos na organização de turmas homogêneas a partir de uma revisão de dois tipos de estudos: naturais e experimentais ou quase-experimentais. Os primeiros são aqueles em que os pesquisadores apenas observam as turmas por níveis de desempenho sem realizar qualquer tipo de intervenção. Nos segundos, os pesquisadores buscam neutralizar o efeito de outras variáveis de modo a apreender 
especificamente o efeito dessa forma de composição de turmas. Sua intervenção se dá no sentido de evitar, por exemplo, que professores menos motivados sejam alocados para as classes com alunos de menor desempenho, bem como de evitar que esses alunos recebam um ensino de pior qualidade comparativamente àquele oferecido aos alunos de melhor desempenho. Sua revisão apresenta achados interessantes.

As pesquisas que caracterizam estudos naturais apontam para efeitos majoritariamente prejudiciais no plano socioafetivo para os alunos com menor desempenho em turmas homogêneas. Nessas turmas, os professores costumam ter uma atitude fatalista em relação a esses alunos, que geralmente recebem um ensino de menor qualidade (menos conteúdo e tempo dedicado ao ensino, incentivos mais raros e menos entusiastas, e mais exercícios de repetição). Ao passo que esses alunos não progridem bem - podendo até mesmo regredir - os alunos de maior desempenho conseguem progredir bem. Isso ocorreria muito por conta de sua inserção em turmas mais privilegiadas, que desfrutam de um prestígio maior na organização, influenciando diretamente o tipo de trabalho pedagógico realizado com eles. Como tem sido visto ao longo do trabalho, uma atitude fatalista semelhante parece se desenvolver na Escola Sigma em relação às turmas homogêneas que caracterizam os projetos de correção de fluxo.

Já as pesquisas experimentais ou quase-experimentais revisadas por Crahay (2007) apontam uma amplitude de efeito nulo no que diz respeito à evolução diferenciada dos alunos em turmas homogêneas ou heterogêneas. Em outras palavras, quando a qualidade e a quantidade do ensino oferecido para os diferentes alunos permanecem as mesmas, a composição de turmas homogêneas não favorece os alunos de melhor desempenho ou prejudica aqueles de menor desempenho. Quando essas variáveis não são controladas, pelo contrário, observase uma tendência à hierarquização das turmas no interior da instituição, o que leva a uma maior desigualdade no ensino oferecido e, consequentemente, impacta o desempenho dos alunos.

Lima (2016) cita, ainda, pesquisas nacionais que confirmam que os resultados das turmas homogêneas podem variar, a depender da mobilização da organização em torno delas. Barboza (2006), por exemplo, mostra que alunos em atraso escolar podem ser beneficiados quando agrupados nessas turmas desde que haja uma "política consciente" para que sejam atendidos da melhor forma 
possível. Sem isso, as turmas homogêneas podem, de fato, vir a agravar a situação de desvantagem desses grupos, como também aparece em Crahay (2007).

Diante dessas breves considerações, cabe refletir a respeito de determinadas práticas de composição de turmas ocorridas no interior da Escola Sigma, que foram reconstruídas nas entrevistas com os atores escolares. Um caso específico e bastante significativo diz respeito à reenturmação no $6^{\circ}$ ano regular de alunos que haviam participado de projetos de correção de fluxo nos anos iniciais. Primeiramente, cabe reconstruir a trajetória desses alunos, com base na entrevista realizada com sua professora de projeto nos anos iniciais, a professora Gisela.

A professora Gisela havia entrado na escola Sigma em 2013, portanto, três anos antes de nossa pesquisa na escola. Ela conta que, assim que chegou, foi alocada para dar aula na turma de Realfabetização 1 , composta por alunos repetentes do terceiro ano que ainda não conseguiram ser alfabetizados. Ela explica que esse encaminhamento não se deu com base em uma escolha sua. Nesse sentido, vale a pena contrastar o discurso oficial da política e o que parece ter ocorrido com a professora na Escola Sigma.

Como pontua Lima (2016), já em 2009, no primeiro ano de implementação dos projetos, as direções das escolas foram orientadas a selecionar para o trabalho com as turmas de projeto aqueles professores que tivessem tido experiências bemsucedidas em alfabetização (objetivo original dos projetos neste primeiro ano). Nesse sentido, os professores deveriam ser aqueles considerados "a prata da casa", e que desejassem envolver-se com um trabalho diferenciado. A autora destaca que, segundo as técnicas entrevistadas da SME, foi possível a formação de um banco de reserva com esses professores, ainda que muitos tivessem se inscrito a contragosto, porque a diretora pediu. Nesse ponto, cabe destacar que não havia nenhum incentivo financeiro oferecido pela SME aos professores dos anos iniciais do Ensino fundamental para trabalhar em turmas que se mostravam mais desafiadoras, ao contrário do que ocorria nos anos finais. Como, no trabalho com o segundo segmento, um professor especialista passava à função de generalista, acumulando maior carga horária, ele tinha um aumento salarial significativo.

Essa diferença de incentivo entre os professores de projeto nos anos iniciais e finais foi constatada na presente pesquisa. Conforme apontaram diversos agentes entrevistados, embora o trabalho com os projetos constituísse um grande desafio, o incentivo financeiro oferecido no segundo segmento se mostrava um estímulo 
para que muitos professores convidados aceitassem a proposta vinda da direção. Quanto aos critérios que norteavam essa escolha, os agentes relatam que, no geral, a direção buscava ver quem tinha perfil ${ }^{47}$ de projeto, e que convidava a pessoa. Já no caso dos professores dos projetos anos iniciais, bem como dos professores especialistas de Inglês, Educação Física e Artes que trabalhariam com os projetos nos anos finais, no dia de blocagem, percebeu-se maior resistência ${ }^{48}$. Nesse sentido, a professora Gisela enfatiza que seu encaminhamento para o trabalho com a turma Realfabetização 1 em 2013 não foi uma escolha sua. Na percepção da dessa agente, quando um professor chega a uma nova escola, geralmente recebe a "a pior turma, aquela que que ninguém quer". Nesse momento, relata que esse seria o caso da turma de Realfa, da qual ninguém gostava, uma vez que seria composta por "crianças que têm outros tipos de comprometimento" para além do analfabetismo. Mais especificamente, diz ser uma turma de crianças com um “comportamento horrível”, portanto, muito difícil.

Essa percepção ecoa a fala de outra professora generalista dos anos iniciais que era mais antiga na escola e que nunca havia trabalhado com turmas de projeto. Quando perguntamos a ela como se dava o encaminhamento dos professores para essas turmas, ela primeiramente responde que a direção sempre foi aberta para que os professores se colocassem em relação às turmas em que se sentiam mais à vontade para trabalhar, com base em sua experiência. Contudo, ela faz um adendo logo em seguida: "É óbvio que, muitas das vezes, acaba que alguns professores que estão chegando novos é que se propõem mais a esse desafio, são colocados pra esse desafio, né, mas já houve casos de professores quererem pegar".

\footnotetext{
${ }^{47}$ Quando perguntamos à diretora no que exatamente consistia esse perfil, ela disse que "ter perfil é gostar". Nesse sentido, diz que consegue perceber, pelas atitudes do professor, quem consegue ou não. Afirma que todos costumam hesitar e/ou apresentar resistência no começo, mas que depois consegue convencer aqueles que tivessem perfil ("quem não tem, não adianta, você não tem um argumento que vá convencer"). A professora Esther menciona que os professores de projeto têm que ser "muito mais abertos e diversos, e com uma linguagem muito mais descolada do que os outros professores". Segundo ela, se forem muito rígidos, "os alunos botam o professor pra correr".

${ }^{48}$ Cabe destacar que, na presente pesquisa, foram entrevistadas apenas três professoras nessa situação: as professoras de inglês Olívia (que trabalhava com a turma de projeto remanescente na escola em 2016) e Denise (que havia trabalhado com turma de projeto anteriormente) e a professora dos anos iniciais Gisela. As três professoras indicaram insatisfação em relação o trabalho com os projetos, reforçando que seu encaminhamento para essas turmas não foi uma escolha voluntária. No caso das professoras de inglês, tratou-se de preenchimento de carga horária e, no caso da professora Gisela, em sua percepção, ela teria sido direcionada a essas turmas por ser nova na escola, e ter ficado com a turma que sobrou.
} 
Complementa reconhecendo que é um trabalho muito difícil e que não tem o devido suporte, e que muitas vezes o professor não tem interesse justamente por essa falta de suporte, e pelo fato da turma ser complicada. Em sua fala, chama atenção a forma como esse encaminhamento de professores mais novos a essas turmas reconhecidamente mais complicadas, e que envolvem um trabalho mais difícil e sem tanto suporte, é caracterizado como algo “óbvio”. Para além disso, há uma reformulação significativa quando a agente alterna a estrutura ativa "alguns professores que estão chegando novos se propõem a esse desafio", que indica volição, disposição, para a passiva "são colocados pra esse desafio", que indica justamente uma agência externa sobre esse encaminhamento. A caracterização desse processo como algo óbvio pode indicar, ainda, uma prática relativamente naturalizada na organização.

Ambos os relatos sugerem, portanto, que a alocação de professores nas turmas de projeto dos anos iniciais não tenha sido motivada por questões de cunho propriamente pedagógico, mas que atendesse a outros critérios, a exemplo da escolha dos professores que tinham mais tempo na escola. Em outras palavras, talvez os mais velhos tivessem mais "direito" a escolher suas turmas.

Voltando ao relato da professora Gisela, observa-se, de qualquer forma, que a professora alocada para essa turma reconhecidamente mais "desafiadora" foi uma que havia acabado de entrar na escola. Uma primeira reflexão aponta, portanto, para a medida em que haveria uma "política consciente" de auxílio a essas turmas mais homogêneas (BARBOZA, 2006) ou uma mobilização por parte da organização na distribuição dos recursos (materiais ou humanos) às diferentes turmas. É importante ressaltar que a própria professora pontua que havia discriminação no interior da escola quanto a essa turma, pelo fato de que "as crianças que estão naquele projeto são crianças sem educação". Quando perguntamos se essa discriminação se verificava por parte dos professores ou alunos, ela dizia que por parte de todos - "eles eram muito mal vistos na escola".

Continuando seu relato, a professora conta que "reprovou mais do que aprovou", pois achou que seus alunos teriam a oportunidade de ter mais um ano para se alfabetizar. Dessa forma, em 2014, grande parte da turma fez novamente o Realfa 1 com outra professora, visto que a agente entrevistada tinha saído da escola nesse ano, retornando somente no ano seguinte. Quando voltou em 2015, conta que ficou com o Acelera 1, onde "pegou umas 13 crianças que tinham sido 
suas no Realfa 1 em 2013, e que ela tinha reprovado. Após passarem pelo Realfa 1 duas vezes (em 2013 e 2014) e pelo Acelera 1 (em 2015), essas crianças foram reenturmadas no $6^{\circ}$ ano regular e 2016. Contudo, não foram distribuídas em turmas diferentes - ficaram todos na mesma turma. A professora conta que ela havia pedido à diretora que assim fosse, pois acreditava que seria melhor para seu aprendizado: "quando o professor trabalhasse com essa turma, já saberia que tem umas crianças que vieram do Acelera, que não tiveram... um ano no $3^{\circ}$, um ano no $4^{\circ}$, um ano no $5^{\circ}$. Eles vieram acelerados. Fica mais difícil, né?" Em outras palavras, a racionalidade alegada pela agente correspondia à crença comumente constada pelas pesquisas na área: as turmas homogêneas possibilitariam que o professor desenvolvesse um trabalho especificamente voltado para aquilo que os alunos precisariam, sendo, portanto, mais eficazes e vantajosas para esses alunos. Contudo, como apontam as próprias pesquisas sobre turmas homogêneas, esses agrupamentos podem tornar-se objeto de estigmatização por parte da comunidade escolar.

Nesse sentido, a entrevista com outros agentes escolares a respeito dessa turma mostrou que havia sérias dificuldades no trabalho com ela. Segundo o relato de uma agente educadora, a reunião desses alunos na mesma turma foi uma questão levantada, pelos pais e pelos atores escolares: "disseram que, se era uma turma que dava problema nos anos passados, por que colocaram todos juntos novamente no sexto ano?". De acordo com a entrevistada, as razões alegadas diziam respeito a um trabalho diferenciado que deveria ser feito com eles. No entanto, sua percepção é de que "prejudicou bastante", em termos pedagógicos e disciplinares. Outra agente menciona que, se por um lado a mistura de alunos diferentes em uma mesma turma é boa, por outro, "essa turma que não é muito boa" pode atrapalhar o rendimento das crianças que "realmente querem aprender", com quem poderia ser feito um trabalho melhor, alcançando melhores resultados.

A motivação declarada para a decisão organizacional de mantê-los juntos parecia ser, como mencionado, o pressuposto de que o agrupamento dessas crianças com maior dificuldade, e que haviam tido uma trajetória mais "tortuosa" em relação às demais, facilitaria o trabalho pedagógico a ser desenvolvido com elas. Contudo, a fala da segunda agente educadora já sugere outra motivação por trás dessa ação, que se assemelha a uma espécie de raciocínio pragmático discutido anteriormente - "salvar a quem se pode salvar" - ou, até mesmo, "quem 
merece ser salvo". Nas palavras da segunda agente educadora, os alunos que não são muito bons poderiam vir a atrapalhar o rendimento das crianças percebidas como mais interessadas, com quem se poderia fazer um trabalho melhor. Mais uma vez, a dimensão do merecimento com base na dedicação para os estudos e na vontade de aprender (a valorização de um ethos de "boa vontade cultural") aparece como um traço importante no processo decisório dos agentes da linha de frente.

Partimos, então, para a entrevista com a professora de Matemática das turmas de $6^{\circ}$ ano, dentre elas, a turma que concentrava esses alunos advindos do Acelera 1 e Realfa 1. Em um primeiro momento, ela relata dificuldades inerentes ao trabalho com o $6^{\circ}$ ano como um todo, que é um ano que muitos professores não gostam de pegar, por conta da transição do primeiro segmento para o segundo, em que os alunos apresentam bastante dificuldade. No geral, diz que os professores preferem ficar com o $7^{\circ}, 8^{\circ}$ e $9^{\circ}$, quando os alunos "já estão mais arrumadinhos", dando o exemplo da professora mais antiga na escola, que gostava de ficar com o $9^{\circ}$ ano. Seu relato sugere novamente que o processo de alocação dos professores nas turmas da Escola Sigma seria mais o resultado de escolha do professor, com prioridade para aqueles mais antigos, do que de uma deliberação baseada em motivações pedagógicas. Para além dos desafios gerais do $6^{\circ}$, ela aponta especificidades da turma em questão:

A única turma que a gente realmente vai trabalhar diferente vai ser a [nome da turma]. Por quê? Porque é a que veio do projeto. Assim, eu acho que eles não têm culpa de ter passado por isso. De chegar aqui... Eu tenho alunos ali que não sabem ESCREVER. Um dia desses no quadro, um aluno veio ao quadro, eu tava ajudando ele. "Então, 7 mais 2?" Silêncio. Aí a coleguinha "é 9, é 9". "Ah, é 9, professora". Quer dizer, não sabe nem o mínimo. 7 mais $2 \ldots$ como é que, né, não consegue fazer isso até de cabeça. Dá pra contar nos dedos, 7 mais 2. Então, eles têm um... [não conclui a frase] (Professora Helena)

A percepção da professora durante a sua entrevista é de que os alunos desta turma tinham um desempenho bastante inferior ao das outras, de forma a lançar dúvidas sobre a eficácia dos projetos pelos quais passaram, no sentido de recuperar sua dificuldade de aprendizagem até mesmo com as habilidades básicas em língua e matemática.

Com a menção a essa turma, perguntamos como tinha se dado a entrada desse projeto na escola, e o encaminhamento de professores para eles, de forma a compreender, por exemplo, por que ela nunca teria sido professora de projeto. Em 
seu relato, ela diz que não acompanhou essa entrada, embora estivesse na escola há dez anos. Como justificativa, afirma que os projetos ficavam "lá em cima", em salas específicas somente para eles: "Fica trancada e tudo, é uma sala do professor de projeto. É uma sala do projeto. Então, acontecia lá em cima, e a gente aqui embaixo não participa tanto". Esse isolamento espacial das turmas de projeto também já tinha sido mencionado por outros agentes, até mesmo por uma das agentes educadoras, que não via de forma positiva essa decisão organizacional. Tentando compreender a possível racionalidade por trás dessa decisão, ela diz não saber se era porque as salas do último andar eram mais preparadas, mas percebe que essa segregação não tinha um efeito bom para os alunos: "além de eles serem tirados das turmas regulares, ainda são colocados lá em cima, aí a turminha que já acompanhavam... eles se sentem realmente separados, eles foram - a palavra que às vezes eles usam - “jogados” lá pra cima”. Em outras palavras, a decisão de concentrar as turmas de projetos - que já concentravam alunos com dificuldade todas em um mesmo andar, além de dificultar mais ainda o envolvimento dos outros agentes escolares no trabalho com essas turmas, parecia concorrer para a maior estigmatização desses alunos.

Ainda a respeito da entrada desses projetos na escola, a professora de Matemática afirma em tom jocoso que, desde o início, não queria pegar essas turmas, apesar da vantagem financeira que o aumento no salário trazia. Como justificativa, ela diz que não se achou capaz, visto que esse trabalho exigia um jogo de cintura que ela não tinha.

Retornando a essa turma específica advinda de projeto, reforça a grande diferença que percebia entre esses alunos e os alunos de turmas regulares, e passa a narrar percepções diferentes e até mesmo contraditórias em relação ao seu agrupamento nessa turma homogênea. Primeiramente, quando perguntamos se toda a turma era oriunda do projeto, ela responde negativamente, e diz que "esse é que é o grande problema". Diz que a turma é mesclada, o que a torna mais bem difícil de trabalhar. Logo em seguida, no entanto, quando indagamos se essa ideia de agrupar todos os alunos oriundos do projeto seria, então, uma boa ideia (em vez de eles se dispersassem em várias turmas), ela muda seu discurso. Diz que não poderiam ter deixado todos esses alunos juntos, uma vez que isso tornou o grupo muito fraco, e os alunos com uma "baixa autoestima imensa". A professora explica, então, o que significava o adjetivo "mesclada" atribuída a essa turma: 
“juntou o projeto, mais alunos que vieram repetentes, mais alunos que vieram de fora, porque tinha vaga na turma”. Em resumo, a turma em questão era composta pelos alunos advindos das turmas de projeto dos anos iniciais, mais alunos repetentes do $6^{\circ}$ ano anterior, mais alunos que vinham de outras escolas. Nas palavras da professora, "não precisa falar mais nada, né, então ficou uma turma realmente difícil da gente trabalhar".

As percepções contraditórias apresentadas pela professora podem indicar tanto a influência do contexto interacional - as expectativas que a entrevistada poderia ter quanto à resposta esperada pela entrevistadora, que mudam diante de uma nova pergunta - ou a própria contradição inerente a essas reflexões sobre o melhor formato de organização das turmas. De qualquer sorte, seu discurso recupera e reconstrói tanto discursos característicos de um saber mais comum e pragmático, quanto discursos de ordem mais científica. Movimenta-se da crença mais comum na facilidade que turmas homogêneas trariam para o trabalho docente, para conclusões características de pesquisas na área educacional quanto ao risco de essas turmas se tornarem mais prejudiciais e estigmatizantes para os alunos em maior dificuldade escolar.

Para além disso, cabe problematizar a crença que a ex-professora de projeto nos anos iniciais (Gisela) havia demonstrado ao afirmar que seria bom que o professor dessa turma já soubesse de sua proveniência do projeto, para que um trabalho melhor pudesse ser feito com ela. Como demonstram os estudos naturais revisados por Crahay (2007) anteriormente, é comum que os professores de turmas homogêneas desse perfil acabem por adotar uma atitude fatalista diante dos alunos, o que pode vir a prejudicá-los. No caso da Escola Sigma, observa-se um fenômeno parecido. O relato da professora de Matemática demonstra certa insatisfação quanto à sua alocação para essa turma: "Quando eu recebi a turma, já me falaram 'ah, essa turma vem de projeto'. Eu fiquei 'poxa, mas nunca quis trabalhar com projeto, aí vocês me deram a turma de projeto [risos]. Não sei nem como trabalhar!'” Ao contrário do que seria previsto, a conscientização sobre essa particularidade da turma não gerou um resultado propriamente positivo na percepção da professora que iria recebê-la - percepção que, segundo ela, seria compartilhada pelos demais professores da turma. Essa percepção poderia vir a influenciar, por sua vez, o tipo de trabalho a ser desenvolvido na turma. Muito embora não se possa afirmar com clareza como se deu esse trabalho, visto que não 
foi desenvolvida uma observação participante, a fala da professora quanto àquilo que percebe que pode fazer por esses alunos diante de suas grandes dificuldades é significativa. Segundo a entrevistada, ela não teria como reter esses alunos no $6^{\circ}$, já tendo tomado a decisão de passá-los, uma vez que não teria mais como ensinar esses alunos àquela altura (meio do ano). Nesse sentido, diz já ter informado à diretora dessa situação, e afirma "contar com a colaboração do professor do $7^{\circ}$, que ele trabalhe essa turma, ou que a divida entre os dois turnos".

O relato da professora sugere uma atitude pouco otimista em relação a esses alunos, a partir da crença de uma incapacidade de ensiná-los naquele momento para que eles pudessem aprender o que precisavam. Diante dessa crença, já havia tomado a decisão de não mais retê-los, mas promovê-los na expectativa de que outro professor pudesse lidar com a situação de forma melhor. Embora, mais uma vez, não se possa afirmar que a postura necessariamente seria diferente com outras turmas, cabe refletir sobre a medida em que essa desistência precoce dos alunos estaria sendo influenciada pela sua concentração em uma mesma turma, e eventualmente também por expectativas previamente formuladas.

Para além disso, não parecia haver na organização - a despeito do que se alegava como motivação para o agrupamento dessas turmas - uma política consciente que evitasse uma atitude pessimista por parte dos docentes, encorajando um trabalho realmente diferenciado com esses alunos. Essa ausência pode ser vista, por exemplo, na alocação de outros professores para essa turma. Como haviam sido reenturmados no $6^{\circ}$ ano, esses alunos agora lidavam com diversos professores especialistas. Contudo, à época da entrevista (julho de 2016), viemos a saber que estavam sem Português desde o início do ano. A professora de Matemática entrevistada conta que a professora de Português da turma era uma nova, que havia chegado naquele ano mesmo à Escola Sigma, e que "ficou uma aula com eles e não aguentou - entrou num dia e saiu no outro". Quando perguntamos se era a mesma professora que estava com as outras duas turmas do $6^{\circ}$ ano (eram três, ao todo), ela disse que não. A professora das outras turmas fazia 40 horas na escola, já trabalhava de manhã e de tarde, e não tinha horário para ficar com essa turma. Contudo, cabe refletir mais uma vez a respeito da decisão organizacional de preencher o tempo da professora mais experiente com as outras turmas de $6^{\circ}$ ano que não aquela que necessitava de um apoio e mobilização maior 
por parte da comunidade escolar, e que acabou ficando com uma professora recém-chegada.

As práticas reconstruídas acima tratam, portanto, do agrupamento de alunos em dificuldade escolar e percebidos por diversos agentes como "problemas" em turmas homogêneas, da separação física das turmas de projeto das demais, e da alocação de professores mais novos para essas turmas mais desafiadoras. Para além dessas, duas outras práticas foram sugeridas nas outras entrevistas: o direcionamento de alunos repetentes para o turno da tarde, e a organização de "turmas de reprovados". A primeira prática foi sugerida com base na percepção de um aluno da tarde que diz estar ali porque repetiu ("quando a pessoa repete, eles passam pra tarde"), o que é de certa forma condizente com a percepção de outro professor, que afirma serem ainda mais complicadas as turmas da tarde. Já a segunda surge da percepção de outra professora entrevistada quanto às "turmas de reprovados, que de vez em quando rola", tornando as turmas extremamente apáticas e desmotivadas.

Práticas como essas tornam possível a inferência de que havia uma distribuição desigual de recursos internos entre os diferentes cidadãos-usuários na Escola Sigma. Mais do que isso, sugerem uma racionalidade por trás dessas escolhas que vão de encontro à motivação comumente alegada quanto ao trabalho pedagógico diferenciado que se pretendia fazer com essas turmas. Essas iniciativas tomadas pela organização parecem ter seu sentido na tentativa de "proteger" e "salvar" aqueles considerados merecedores - notadamente, os que querem aprender, na percepção dos agentes. Para além disso, cabe refletir se práticas como essas seriam mais bem compreendidas como a expressão de um pragmatismo característico dos agentes da linha de frente, ou, até mesmo, de um julgamento moral que buscasse penalizar aqueles considerados não merecedores, ou oferecer-lhes menos do que esforços pragmáticos permitiriam. Em outras palavras, se estaria "salvando aqueles que se pode salvar" ou "salvando aqueles que merecem ser salvos"?

Independentemente da interpretação escolhida ou mais adequada, práticas discricionárias como essas revelam que o exercício da discricionariedade tem uma dimensão política. Nesses casos específicos, por um somatório de fatores, dificuldades e desafios, as regras informais produzidas no interior da organização 
- relatadas e reconstruídas nas entrevistas - podem acabar não contribuindo para uma maior democratização da escola, gerando mais desigualdade.

\section{4. \\ Menos do que o pragmatismo: o mínimo possível para os não merecedores}

Eles falam que é o computador. Que sempre que eu peço pra eles, eles falam "ah, é o computador que escolhe direto, o computador mexe sozinho". Eles falam. Nunca vi isso, computador mexer sozinho. (Aluno do $8^{\circ}$ ano de turma regular)

Em sua análise da escola como organização educativa, Lima (2011) sustenta que a infidelidade normativa coexiste com o normativismo. Isso ocorreria não somente devido à proteção e segurança que a submissão às normas proporciona aos atores, mas também à possibilidade que oferece de que benefícios sejam retirados dessas normas. Segundo o autor, a mesma centralização e formalização que funcionam como uma espécie de "bode expiatório" e que legitimam o discurso de oposição e desculpabilização por parte dos atores pode ser usado por eles para a manutenção de situações consideradas favoráveis, construídas como defesa ou oposição. De fato, como pontuado por Maynard-Moody e Musheno (2003), embora os agentes da linha de frente estejam envolvidos em uma cultura de "nós contra eles" em relação ao chamado "sistema", eles podem tornar-se agentes do Estado - ou fingir sê-los - caso sintam, por exemplo, que o cidadãousuário esteja querendo manipular o sistema em seu próprio benefício.

Para esses autores, ao contrário do que ocorre com os indivíduos "merecedores", os "não merecedores" são construídos como pessoas com falhas de caráter, "espertas" ou manipuladoras. Aqueles que, embora possam vir a apresentar alguma necessidade genuína, sejam considerados responsáveis pela sua dificuldade, não apresentem motivação real de mudar, e que busquem, na realidade, uma via mais fácil para resolver seu problema podem ser identificados dessa forma. Para esses, os agentes do nível de rua não se desdobram ou se dispõem a procurar brechas na legislação, com vistas a beneficiá-los. Pelo contrário, podem optar por seguir estritamente as normas burocráticas ou, ainda, limitar ao máximo o serviço oferecido aos cidadãos-usuários, como uma espécie de punição. Na organização escolar, os agentes podem tornar-se rígidos e intransigentes caso percebam que os alunos estão tentando manipular o sistema, 
"dando uma de espertos", sendo preguiçosos, ou, ainda, questionando sua autoridade de alguma forma.

Os relatos dos entrevistados apontaram para dois "tipos" de reação diferente que os alunos podiam ter diante da possibilidade de encaminhamento para as turmas de projeto. Alguns se sentiam de certa forma injustiçados e estigmatizados e outros, na realidade, pediam para serem dirigidos para essa turma por perceberem ali uma via menos trabalhosa e mais curta para a terminalidade:

Eu sinto que às vezes eles sentem... "Por que que eu vou?" "Mas eu nunca dei trabalho". Porque eles já veem o acelera como sendo uma turma difícil, uma turma do pessoal que não quer nada... "por que eu vou estudar naquela turma?" $\mathrm{E}$ tem aquela turminha do "por que que eu NÃO estou lá?". "Não tem problema repetir não, que ano que vem eu tô na idade e vou pro acelera e vou passar de qualquer forma..." (Agente Educadora 1 - ênfases da própria entrevistada)

A percepção de que determinados alunos pediam ou até mesmo se "esforçavam" para serem enturmados em turmas de projeto também foi compartilhada pela diretora adjunta. Segundo ela, alguns alunos pediam para serem transferidos para essas turmas de modo que pudessem acabar logo a escola: "Muitos alunos pedem. 'Pô, me bota na turma do Acelera aí'. Eu falo 'filho, essa turma são os alunos que têm dificuldade...' 'Mas então, pra eu acabar logo'. Alguns veem dessa forma, uma forma rápida de chegar ao Ensino Médio”. Essa percepção ecoa as conclusões de Almeida (2015) quanto ao desejo desses alunos de "se livrar da escola", bem como muitos parecem querer "se livrar deles".

Durante a entrevista com os alunos de turmas regulares, conseguimos conversar com um aluno do $8^{\circ}$ ano que já havia repetido duas vezes o $6^{\circ}$ ano, acumulando, assim, uma distorção idade-série de dois anos à época - o que já o tornaria elegível para ser admitido em uma turma de projeto. Quando perguntamos por que ele não tinha sido encaminhado para o Acelera, já que apresentava dois anos de distorção idade-série, ele diz que pedia para ir para o projeto, mas que "eles nunca quiseram". A partir daí, tentamos compreender por que motivos, na percepção do aluno, ele não teria sido encaminhado para essas turmas. Primeiramente, ele menciona algo relativo a seu comportamento - "ah, sei lá, eles falaram que é por causa do meu comportamento". Em seguida, ele descreve seu próprio comportamento como "bagunceiro" e inquieto em sala de aula. Mais adiante na entrevista, diz que, quando pedia para entrar no projeto, diziam a ele que era o computador quem escolhia, e não eles: 
Eles falam que é o computador. Que sempre que eu peço pra eles, eles falam "ah, é o computador que escolhe direto, o computador mexe sozinho". Eles falam. Nunca vi isso, computador mexer sozinho. (Aluno do $8^{\circ}$ ano de turma regular)

Nessa mesma turma de $8^{\circ}$ ano, entrevistamos um colega desse aluno que também apresentava dois anos de distorção idade-série, oriundo de duas repetências - uma no $4^{\circ}$ ano e a outra no $8^{\circ}$ ano. Em seu relato, conta que já o haviam chamado para o Acelera, mas que sua mãe não deixou. Segundo ele, sua professora do $4^{\circ}$ ano, à época, conversou com sua mãe e falou que, se viesse a repetir, que evitasse entrar nas turmas de projeto por conta da bagunça que os alunos faziam, que poderiam vir a prejudicá-lo mais à frente.

Embora não se possa afirmar com certeza qual a motivação real por trás do não encaminhamento do primeiro aluno entrevistado para a turma de projeto, a despeito de apresentar o perfil etário para ser enturmado, bem como a vontade expressa de sê-lo, podem-se levantar algumas hipóteses. Primeiramente, é possível que não houvesse, de fato, vagas na turma disponíveis, e que a prioridade fosse dada para quem tinha uma distorção mais alta. Porém, diante dos relatos dos agentes quanto à discricionariedade existente nesse direcionamento, bem como da observação do perfil etário dos alunos da turma de projeto que foram entrevistados (que não diferia muito da idade do aluno que queria ser transferido), pode-se aventar a possibilidade de outra racionalidade por trás desse processo. Essa percepção quanto à discricionariedade no encaminhamento de alunos para os projetos aparece, inclusive, na fala de uma aluna do $8^{\circ}$ ano de turma regular: "Mas é que Acelera é meio escolhido a dedo quem vai entrar no Acelera. É difícil entrar".

$\mathrm{O}$ aluno do $8^{\circ}$ ano que queria entrar no Acelera se encaixava, de certa forma, no perfil de alunos "espertos", que não tinham entendido bem a proposta do projeto, na ótica dos agentes, visto que buscava nele um atalho mais rápido à terminalidade. Diferentemente do outro aluno defasado, este não faz referência a uma família atuante em sua trajetória escolar, que eventualmente o desaconselhasse, ou até mesmo o impedisse, de seguir esse percurso mais curto. Pelo contrário, o aluno conta que seus dois irmãos também cursaram o Acelera. Diz não perceber diferenças de conteúdo entre o projeto e o ano regular, e pensa valer a pena ser transferido, por conta de seu atraso. O outro aluno defasado, por 
sua vez, afirma que "o ensino deles é muito abaixo do nosso", e que a aceleração dos conteúdos pode acabar confundindo mais do que ajudando.

Aventa-se a possibilidade, portanto, de que os agentes escolares tenham sido, de certa forma, inflexíveis em relação à entrada desse aluno em turmas de aceleração como forma de resposta à sua tentativa de manipulação do sistema. Para tal, mais do que uma observância estrita das regras, as teriam até mesmo tornado mais duras, de forma a não atender à vontade considerada ilegítima desse aluno. Como justificativa, podem lançar mão do argumento de que é o sistema que escolhe quem deve ou não ser encaminhado para os projetos, o que ilustra de que forma o sistema pode ser usado na manutenção de situações consideradas justas ou favoráveis. Portanto, ao contrário dos esforços extraordinários feitos para que aqueles considerados "merecedores" pudessem ser integrados a essas turmas, ou até mesmo "poupados" delas, as regras seriam estritamente observadas ou enrijecidas quando se trata de "não merecedores".

Episódios como os reconstruídos pelos entrevistados acima sugerem que os trabalhadores da linha de frente ora podem significar suas atividades mais como um serviço ao cidadão-usuário do que a um sistema impessoal e distanciado, e ora podem tornar-se rígidos burocratas. Essa "conversão" a (ou "disfarce” como) agentes do Estado, por sua vez, não ocorreria necessariamente por conta de uma real fidelidade ao sistema, mas por seus próprios valores. Dessa forma, os serviços limitados ou até mesmo as punições que aplicam àqueles considerados não merecedores encontram uma justificativa moral em suas histórias. 


\section{7 \\ Considerações Finais}

O presente trabalho buscou compreender a implementação de um projeto de aceleração da aprendizagem em uma escola da rede pública municipal do Rio de Janeiro, a partir das percepções dos agentes implementadores. Como visto anteriormente, o principal propósito das políticas de correção de fluxo, implementadas por meio de programas e projetos de aceleração da aprendizagem, é a recuperação do atraso escolar de alunos multirrepetentes. Para tal, prevê-se a formação de turmas homogêneas com os alunos que apresentam dois ou mais anos de distorção idade-série, e a condução de um trabalho diferenciado com essas turmas. Trata-se, portanto, de uma intervenção pedagógica que busca empregar uma metodologia de ensino alternativa, que permita a posterior reintegração desses alunos em turmas regulares de anos mais avançados, regularizando sua trajetória. Dessa forma, busca-se também um efeito de desobstrução do fluxo escolar.

A importância dessas políticas pode ser compreendida a partir da frustração das expectativas depositadas na expansão do sistema educacional a todos os setores da população. Como visto ao longo do capítulo 2, quando acesso à escolarização era bastante restrito, acreditava-se que as desigualdades educacionais seriam solucionadas com a ampliação do sistema escolar às camadas populares que anteriormente sequer o acessavam. No entanto, mesmo após a incorporação desses setores, observaram-se outros mecanismos de seletividade dentro do sistema, a exemplo das dificuldades de progressão com sucesso que passaram a protagonizar, traduzidas nas elevadas taxas de repetência e distorção idade-série.

Ao longo do capítulo 2, também pôde-se perceber que essa "crise" atribuída aos sistemas educacionais após sua democratização não é um fenômeno somente brasileiro. Nesse sentido, o sociólogo francês Pierre Bourdieu apresenta uma explicação para a reprodução de uma situação de exclusão social que anteriormente se verificava no exterior da escola e que, a partir de sua ampliação a 
outras camadas, passa a ser observada também no seu interior. Segundo a perspectiva bourdieusiana, o fracasso escolar das crianças das camadas populares é construído a partir da seleção, por parte da instituição escolar, de um arbitrário cultural já familiar aos filhos das camadas mais privilegiadas, sendo-lhes transmitidos de maneira quase natural por meio da socialização familiar. Dessa forma, observa-se uma desigualdade inicial entre os "herdeiros" e os "não herdeiros" de uma cultura letrada e demais conhecimentos valorizados pela escola. Dentre os não herdeiros dessa cultura, aqueles que herdam ao menos um ethos de ascensão social pela escola, característico das camadas médias, têm mais chances de sucesso pela via escolar. Mesmo que não tenham a mesma facilidade que os "herdeiros", sua "boa vontade cultural" os leva a empenhar-se na sua trajetória escolar, e, com isso, a desfrutar de um julgamento positivo por parte dos docentes. Os filhos das camadas populares que não herdam nem um capital cultural escolarmente rentável, nem mesmo esse ethos de ascensão pela escola são aqueles que normalmente refugiam-se em uma espécie de atitude negativa em relação à instituição, influenciada também por um julgamento negativo por parte dos agentes escolares.

A reprodução de uma condição de exclusão anterior à escola no interior dessa instituição sugere a ausência do que Bourdieu chama de uma "pedagogia racional" que se propusesse a ensinar a todos, e não somente àqueles que já dispõem de vantagens iniciais. Essa ausência de uma função educadora autossuficiente por parte da escola é também apontada por Sérgio Costa Ribeiro (1991). Para o autor, o modelo de escola que se expandiu às camadas populares no Brasil só fazia sentido quando o sistema educacional atendia a uma pequena elite, para quem funcionava mais como um preceptor da educação familiar do que como mentor de um processo de ensino-aprendizagem autônomo. Dessa forma, ao se expandir àqueles que não tinham essas mesmas experiências, tem seu sentido esvaziado, passando a ser compreendido muitas vezes como uma creche, um restaurante, ou um "depósito de crianças". Torna-se raro encontrar uma organização escolar que se comprometa a um processo formal de ensino no seu interior independentemente da situação social do estudante. Um dos resultados do esvaziamento dessa função educadora pode ser visto na naturalização do fenômeno da repetência, compreendido por Costa Ribeiro como um elemento cultural da práxis pedagógica dos agentes escolares. O fracasso dos alunos na 
escola raramente é imputado à própria organização, mas aos próprios alunos, a suas famílias, ou a um sistema mais amplo.

Essa perspectiva foi encontrada no presente estudo, que, como exposto, buscou investigar a implementação de uma política que visava intervir sobre o fenômeno do fracasso escolar compreendido como repetência no nível da escola. A importância de estudos que se debrucem sobre a fase de implementação se dá a partir de observações de que nem sempre os objetivos expressos nessas políticas são plenamente atingidos no momento em que elas são postas em ação, como foi visto ao longo do capítulo 3. Para melhor compreender de que forma a política foi executada na escola selecionada, elegemos como foco de análise os agentes implementadores diretos (os professores, gestores e demais membros da comunidade escolar). Conforme também apresentado no capítulo 3, esses agentes da linha de frente do serviço público tornam-se verdadeiros "fazedores" de políticas ao desfrutar de uma considerável margem de discricionariedade na execução de suas atividades rotineiras. O exercício de sua discricionariedade, por sua vez, é influenciado por suas ideias, crenças e valores, o que torna significativo o estudo de suas percepções. Considerando que esses valores não são apenas individuais, mas construídos socialmente, buscamos articular as percepções e as avaliações morais dos agentes implementadores às discussões sobre o julgamento docente empreendidas por Bourdieu, destacando a valorização de um ethos de ascensão social pela escola na percepção sobre os alunos.

Considerando, ainda, que essas crenças e valores são também (re)construídos nas diversas interações que ocorrem no contexto organizacional, buscamos olhar para a própria escola selecionada, onde a política em tela foi implementada. Aliás, cabe destacar que, se a Escola enquanto instituição se mostra reprodutora das desigualdades sociais em uma perspectiva bourdieusiana, as escolas enquanto organizações têm seus próprios ethos (RUTTER et al, 1979), podendo ser uma variável explicativa importante nos resultados dos alunos. Nesse sentido, a depender da missão e dos valores cultivados no seu interior, podem tanto contribuir para a reprodução dessas desigualdades, quanto se mostrarem eficazes na atenuação do peso das origens sociais sobre o desempenho escolar dos alunos.

Dessa forma, o capítulo 4 buscou analisar a estrutura programática que envolvia os agentes implementadores - a política de correção de fluxo em si - e o 
ambiente organizacional em que atuam. Nesse primeiro movimento de investigação, realizamos uma análise dos documentos relativos à política de correção de fluxo desenvolvida na rede pública municipal do Rio de Janeiro a partir de 2009, a partir da ampla revisão de Lima (2016), e uma breve descrição escola selecionada.

A análise da política desenvolvida no município do Rio de Janeiro ao longo desses anos indicou um processo contínuo de formulação e reformulação, visto que a cada ano novos projetos eram inseridos e modificados em relação aos anos anteriores. Também foi notável a ausência de objetivos claros a serem alcançados pela política desde o primeiro ano de sua implementação. Como visto ao longo do capítulo 3, esses são fatores que aumentam a possibilidade de diferentes interpretações e, consequentemente, a margem de discricionariedade dos agentes implementadores. Apesar de se configurar em uma iniciativa estratégica da Secretaria a partir da entrada de uma nova gestão em 2009, não foram encontrados documentos oficiais fundadores do projeto neste ano. Da mesma forma, ainda que essa nova gestão tenha ficado conhecida pelo estabelecimento de metas, pela implantação de sistemas de avaliação e pelas políticas de accountability, o trabalho com os projetos esteve sempre isento de avaliações externas à rede e às fundações e instituições parceiras.

No que diz respeito à escola selecionada para nosso estudo de caso, à qual atribuímos o nome fictício de Escola Sigma, pode-se dizer que ela representou um exemplo característico de escola onde foi implementada a maior parte dos projetos de correção de fluxo. Contando com mais de 1000 alunos, 100 funcionários e diferentes etapas de ensino, a Escola Sigma pode ser classificada como uma escola de enorme porte (LIMA, 2016), cuja gestão pedagógica e administrativa é mais complexa (OLIVEIRA, 2015). Esse fator é agravado pela ausência de funcionários, a exemplo de um coordenador pedagógico que faça a mediação entre os agentes.

As percepções dos agentes escolares a respeito da escola em que trabalhavam, explorada ao fim do capítulo 4, ressaltavam o enorme porte da escola e sua grande complexidade. A partir da análise das entrevistas, foi também possível perceber um enfraquecimento da missão pedagógica da escola. Dois elementos principais pareciam concorrer para esse esvaziamento de sentido: as dificuldades estruturais enfrentadas para a manutenção de um clima propício de 
aprendizagem (como o elevado número de alunos atendidos e a ausência de funcionários na organização), e determinadas crenças e valores que se mostravam dominantes na comunidade escolar. Em relação a esses últimos, parece prevalecer a percepção de que o novo público que a escola vem recebendo precisa de outro foco que não exatamente a aprendizagem. Para esses alunos, a escola parece assumir um foco socializador, centrado na obediência a regras, ou de formação para a cidadania, que é visto de forma apartada da construção de conhecimento escolar. Parece haver, portanto, uma espécie de ressignificação da missão da escola diante de um novo público, cuja disciplina e interesse na vida escolar não são os mesmos dos alunos de antes, aos olhos dos agentes.

Essa percepção sobre os alunos torna-se ainda mais clara quando tratamos do público-alvo dos programas de aceleração de aprendizagem, no capítulo 5. Os alunos com atraso escolar inseridos nas turmas de projeto são percebidos principalmente como alunos "problemáticos", desinteressados, indisciplinados e por vezes, como portadores de deficiência cognitiva. Poucos são os agentes que cogitam a possibilidade de que o mau comportamento, o desinteresse e a dificuldade de aprendizagem sejam também efeitos e não somente as causas da baixa aprendizagem dos alunos. Em outras palavras, poucas vezes (co)responsabiliza-se a própria organização pela aprendizagem dos alunos e por seu eventual fracasso.

Ainda no capítulo 5, passamos a algumas percepções sobre a política de correção de fluxo em si, desenvolvida na Escola Sigma e na rede municipal como um todo. Nesse sentido, observamos uma perda de legitimidade aos olhos dos agentes da linha de frente de determinadas diretrizes da política, a exemplo da metodologia de ensino e do formato de polivalência do professor. A metodologia proposta era considerada bastante ultrapassada, bem como destinada a outro público que não os alunos inseridos nas turmas de projeto nos anos finais do Ensino Fundamental. Do mesmo modo, a escolha de um professor especialista do segundo segmento para trabalhar com todas as disciplinas foi considerado algo bastante desafiador e irrealista, no sentido de que inevitavelmente acarretaria uma perda de conteúdo para os alunos. Como pontuado por Licínio Lima (2011), comumente o enfraquecimento da legitimidade de regras formais na escola dá origem à produção de regras alternativas por parte dos atores, que encontram novas bases de legitimação para justificar suas ações. Essa substituição de regras 
consideradas irrealistas e insustentáveis por "improvisações exequíveis" também constitui um traço característico do trabalho ao nível da rua, segundo MaynardMoody e Musheno (2003). Diante dessa situação, diversos agentes relataram a produção de material alternativo para trabalhar com os alunos nas turmas de projeto, bem como articulações entre professores e "redes de cumplicidade mútuas" (LIMA, 2011) para lidar com a polivalência.

A percepção da eficácia dessas estratégias podia variar entre os entrevistados. No entanto, a percepção que se mostrou predominante em relação a esse aspecto da política - que, para os agentes, dizia muito sobre a política como um todo - é a de que esse formato era algo "absurdo", e que os alunos não conseguiriam recuperar completamente seu atraso escolar em termos de conteúdo. Nesse sentido, destacam que a política não estaria verdadeiramente comprometida com o aprendizado desses alunos, mas sim com a aceleração da sua terminalidade e sua saída do sistema. Outro propósito ao qual atenderia, ainda, seria a "limpeza" das turmas regulares que fariam as avaliações externas, de forma que os alunos com maior dificuldade ficassem "concentrados" nos Aceleras, e os índices de qualidade fossem menos prejudicados.

Ao fim do capítulo 5, ainda investigando indícios de discricionariedade na execução da política, realizamos uma incursão exploratória sobre os dados do Censo Escolar ao longo dos anos de 2010 a 2014. A partir dela, pudemos notar que algumas turmas de correção de fluxo foram preenchidas em anos regulares distintos daqueles aos quais se referiam, e que, nos anos de 2013 e 2014, o número de alunos matriculados em turmas de projeto parecia ter sido subnotificado na base de matrículas. Por fim, observamos um número considerável de alunos que não apresentavam um atraso escolar de dois ou mais anos matriculados em turmas de projeto, ao passo que outros - que apresentavam a distorção idade-série prevista - não pareciam ter sido atingidos pela política. Todos esses dados pareciam sugerir uma margem de discricionariedade no encaminhamento de alunos para essas turmas, possivelmente baseada em interpretações diferentes da política e de percepções específicas sobre o públicoalvo que deveriam atingir.

A partir dessas constatações, passamos ao capítulo 6. Neste capítulo, observamos o exercício da discricionariedade principalmente em relação a dois aspectos: o encaminhamento de alunos para as turmas de projetos, e a distribuição 
de recursos materiais e humanos para os diferentes alunos dentro da escola (incluindo, nesse último ponto, a seleção de professores para o trabalho com os projetos). Nesse momento, observamos que a alocação de recursos no interior da organização, bem como a decisão sobre os alunos que participarão dos projetos parecia ser influenciada por um senso prático-moral, baseado em uma percepção de merecimento dos alunos.

Analisamos a percepção de merecimento como resultado de uma avaliação somativa, com base na proposta de Maynard-Moody e Musheno (2003). Nesse sentido, observamos que os elementos que, agregados, competem para que os alunos sejam considerados "merecedores" ou "não merecedores" são: a necessidade genuína que apresentam (o quanto os alunos precisam de determinado serviço), a causa dessa necessidade (o quão responsáveis os alunos seriam sobre sua condição), a motivação para a mudança (compreendida como cooperação com o trabalho do agente da linha de frente), traços de caráter (honestidade), e a capacidade de retorno. Cabe ressaltar que todos esses termos seriam "filtrados" pela percepção dos agentes, momento em que entram em jogo seus próprios valores morais e a relevância de um ethos de "boa vontade" em relação à escola.

A partir de então, pudemos observar que, para atender a alguns alunos percebidos como "merecedores", os agentes se esforçam de forma extraordinária, eventualmente contrariando regras ou oferecendo um serviço que formalmente não estaria previsto. Esse seria o caso, por exemplo, da tentativa da professora Célia de colocar sua aluna em uma turma de projeto, ainda que ela não tivesse o perfil etário exigido pela política. Não tendo logrado êxito, a professora passa a oferecer uma espécie de reforço escolar individual à aluna após suas aulas. Já para os alunos considerados "não merecedores", os agentes não se esforçam em burlar ou "dobrar" algumas regras. Pelo contrário, por vezes parecem oferecer-lhes menos do que aquilo a que, a princípio, estaria previsto nas diretrizes formais. Esse poderia ser o caso do aluno do $8^{\circ}$ ano que apresentava um atraso escolar de dois anos, que já o qualificava como público-alvo da política de correção de fluxo, mas que não parecia "conseguir entrar" nas turmas de projeto

Entre esforços extraordinários e mínimos, encontramos certas práticas que parecem ser predominantes no espaço escolar. Na retórica de justificativa dos agentes entrevistados, elas aparecem como fruto de um pragmatismo que busca "salvar a quem se pode salvar", diante das tantas limitações enfrentadas no "chão 
da escola". No entanto, cabe refletir sobre a medida em que constituem, mais do que atitudes pragmáticas, ações que também incorporam uma dimensão moral, orientadas a "salvar a quem merece ser salvo". Trata-se, nesse sentido, de unir um movimento hermenêutico compreensivo em relação às atitudes dos agentes e à racionalidade que as embasam a um movimento dialético crítico em relação às consequências que essas ações podem ter para a reprodução social no interior da organização escolar. Exemplos dessas práticas poderiam ser a "reserva" de determinado material que se encontra escasso na organização àqueles alunos que oferecem maior capacidade de retorno, bem como a organização de turmas homogêneas somente com os alunos advindos de projetos, para a qual se direcionam professores recém-chegados na escola.

Cabe refletir, portanto, sobre os limites e possibilidades desse senso práticomoral que parece orientar uma parte considerável das ações discricionárias observadas na presente pesquisa. Por um lado, invenções e improvisações pragmáticas são muitas vezes realizadas pelos agentes escolares como forma de lidar com as contingências do contexto de implementação e com a inadequação das próprias regras formais, numa tentativa de torná-las mais significativas para o público-alvo da política. Como exposto, esse parece ser o caso das articulações entre docentes para lidar com os desafios da polivalência e da defasagem do material padronizado. Por outro lado, esse mesmo senso de pragmatismo pode ser permeado por juízos morais que percebem os alunos de forma binária e relativamente estereotipada. Nesse sentido, os mesmos agentes podem orientar suas ações com base em valores culturalmente arraigados, a exemplo de uma percepção de meritocracia distorcida, que seleciona os alunos que devem receber recompensas e punições. Essa ressignificação da aprendizagem escolar, que passa a ser vista como uma recompensa reservada a alguns, põe em cheque o ideal de uma educação pública de qualidade, voltada indistintamente para toda a população.

Devemos ressalvar que essa (re)atribuição de sentido se opera, no caso analisado por esta pesquisa, em um cenário de intensa sobrecarga de trabalho e falta de recursos. Nesse quadro de escassez, escolhas éticas e morais tornam-se ainda mais relevantes no trabalho ao nível da rua, por sua capacidade de influenciar significativamente a elegibilidade dos cidadãos no acesso ao serviço público. Nesses contextos, aumenta-se não apenas a discricionariedade dos 
agentes na decisão sobre quem recebe o quê do governo, mas também a pressão exercida sobre eles na gestão dos recursos disponíveis.

Dessa forma, e já reconhecendo as limitações desta pesquisa, consideramos ser oportuna a realização de estudos que contemplem a implementação de políticas do gênero em outros contextos. Assim, seria possível aferir, por exemplo, em que medida o senso prático-moral dos agentes é guiado de uma maneira diferente em escolas de menor porte e com relativa disponibilidade de recursos materiais e humanos.

Outra limitação importante deste trabalho diz respeito à forma como o material empírico foi gerado, ou seja, por meio de entrevistas. Se os relatos dos agentes implementadores, por um lado, constituem um instrumento privilegiado para a captação e compreensão de suas percepções, crenças e valores, por outro, eles nos limitam a uma aproximação da ação organizacional. Dito de outro modo, apreendemos de forma indireta tanto as ações discricionárias dos agentes quanto a interação entre eles, uma vez que elas são sempre mediadas pelos seus discursos e pelas realidades que constroem nas situações de entrevista. Dessa maneira, acreditamos que estudos futuros que recorram a instrumentos adicionais de pesquisa qualitativa, tais como a observação de campo, podem oferecer uma grande contribuição para a temática.

Por fim, em se tratando de um estudo de caso, reconhecemos que a metodologia escolhida prioriza o "conhecimento do particular" (ANDRÉ, 2015, p. 31). No entanto, concordando com Fonseca (1999), acreditamos que um estudo de caso que busque a dimensão social dos comportamentos individuais possa contribuir para a "procura de sistemas que vão sempre além do caso individual" (p. 59). Nesse sentido, buscamos realizar um esforço constante de comparação entre as situações singulares investigadas e estruturas mais gerais já tratadas em outros estudos e referenciais teóricos. Dessa forma, esperamos ter contribuído, a partir da análise das percepções dos agentes entrevistados, para a compreensão da política de correção de fluxo existente no Rio de Janeiro, assim como dos desafios que giram em torno de sua implementação em escolas de grande e enorme porte. 


\section{8 \\ Referências bibliográficas}

ALAVARSE, O. M.; MAINARDES, J. Fluxo escolar. In: OLIVEIRA, D. A.; DUARTE, A. M. C.; VIEIRA, L.M.F. DICIONÁRIO: trabalho, profissão e condição docente. Belo Horizonte: UFMG/Faculdade de Educação, 2010. CDROM. Disponível em: http://www.gestrado.net.br/pdf/7.pdf. Acesso em 04/03/2017

ALVES, M. T. G.; FRANCO, C. A pesquisa em eficácia escolar no Brasil: evidências sobre o efeito das escolas e fatores associados à eficácia escolar. In: BROOKE, N; SOARES, J. F. (Org.). Pesquisa em eficácia escolar: origem e trajetórias. Belo Horizonte: Editora UFMG, 2008.

ALMEIDA, R. C. O destino dos mais fracos: a inclusão subalterna. Um estudo sobre alunos inseridos em classes de aceleração da aprendizagem. $2015.111 \mathrm{f}$. Dissertação (Mestrado em Educação). Pontifícia Universidade Católica do Rio de Janeiro, Rio de Janeiro, 2015.

ANDRÉ, M.E.D.A. Etnografia da prática escolar. $14^{\text {a }}$. ed. Campinas: Papirus, 2008 .

BARBOSA, M. L. de O.; RANDALL, L. Desigualdades sociais e a formação de expectativas familiares e de professores. Caderno CRH, Salvador, v. 17, n. 41, p. 299-308, mai./ago. 2004.

BARBOSA, T. M. M. F. A implementação do Projeto Acelerar para Vencer (PAV) em uma unidade escolar: das intenções às ações. 2013. 196 f. Mestrado Profissional em Gestão e Avaliação da Educação Pública, Universidade Federal de Juiz de Fora, Juiz de Fora, Minas Gerais, 2013.

BARBOZA, E. M. R. A composição das turmas e o desempenho escolar na rede pública de ensino de Minas Gerais. 2006. 100 f. Tese (Doutorado em Educação) - Pontifícia Universidade Católica do Rio de Janeiro, Rio de Janeiro, 2006

BARRETT, S. M. Implementation studies: time for a revival? Personal reflections on 20 years of implementation studies. Public Administration, v. 82, n. 2, p. 249-262, 2004.

BOURDIEU, P.; CHAMBOREDON, J. C.; PASSERON, J. C. Le métier de sociologue. Paris: Mouton, 1968.

BOURDIEU, P. A escola conservadora: as desigualdades frente à escola e à cultura. In: NOGUEIRA, M. A. e CATANI, A. (orgs.). Escritos de Educação. $16^{\mathrm{a}}$ ed. Petrópolis: Vozes, 2015, p. 43-72

Os três estados do capital cultural. In: NOGUEIRA, M. A. e CATANI, A. (orgs.). Escritos de Educação. 16 ${ }^{\mathrm{a}}$ ed. Petrópolis: Vozes, 2015, p. $79-88$ 
BOWLES, S.; GINTIS, H. Does schooling raise earnings by making people smarter? In: ARROW, K.; BOWLES, S.; DURLAUF, S. (eds). Meritocracy and economic inequality. Princeton: Princeton University Press, p. 118-136, 2000.

BRANDÃO, Z.; BAETA, A. M. B.; ROCHA, A. D. C. Evasão e repetência no Brasil: a escola em questão. $2^{\text {a }}$ ed. Rio de Janeiro: Dois pontos, 1985.

BRASIL. Lei no 9.394, de 20 de dezembro de 1996. Estabelece as diretrizes e bases da educação nacional.

Plano de Desenvolvimento da Educação, Plano de Metas Todos

Pela Educação, Instrumento de Campo, Brasília, DF, Ag., 2008. Disponível em: http://portal.mec.gov.br/arquivos/pdf/diagnostico.pdf. Acesso em: 04/02/2017.

CARVALHO, M. P. Quem são os meninos que fracassam na escola? Cadernos de Pesquisa. v. 34, n. 121, p. 11-40, jan./abr. 2004

CASASSUS, J. Descentralização e desconcentração educacional na América Latina: fundamentos e crítica. Cadernos de Pesquisa, n. 74, p. 11-19, 1990.

CASASSUS, J. As reformas educacionais na América Latina no contexto da globalização. Cadernos de Pesquisa, n. 114, p. 7-28, 2001.

COHEN, M. D.; MARCH, J. G.; OLSEN, J. P. A garbage can model of organizational choice. Administrative Science Quarterly, v. 17, n. 1, p. 1-25, 1972.

COLEMAN, J. S. Equality of Educational Opportunity. Washington: Office of Education, U. S., 1966.

COLLINS, R. Functional and conflict theories of educational stratification. American Sociological Review. v. 36, n.6, p. 1002-1019, 1971

COSTA, J. A.; CASTANHEIRA, P. A liderança na gestão das escolas: contributos de análise organizacional. Revista Brasileira de Política e Administração da Educação, v. 31, n. 1, p. 13-44, jan./abr. 2015

COSTA, M.; SILVA, G. M. D. Amor e desprezo: o velho caso entre sociologia e educação no âmbito do GT 14. Revista Brasileira de Educação, n. 22, p. 101120, jan./abr. 2003

COSTA RIBEIRO, S. A Pedagogia da Repetência. Estudos Avançados, São Paulo, v. 5, n. 12 p. 6-21, maio/ago.1991

A educação e a inserção do Brasil na modernidade. Cadernos de Pesquisa, São Paulo, n. 84, p. 63-82, fev. 1993.

CORREA, E. V. Efeito da repetência nos anos iniciais do Ensino Fundamental: um estudo longitudinal a partir do Geres. 2013. $124 \mathrm{f}$. Dissertação (Mestrado), Pontifícia Universidade Católica do Rio de Janeiro, Departamento de Educação, Rio de Janeiro, 2013.

CRAHAY, M. Peut-on lutter contre l'échec scolaire? 2 ed. rev. et aug. Bruxelles: De Boeck, 2003

. Qual pedagogia para os alunos em dificuldade escolar? Cadernos

de Pesquisa, v. 37, n. 130. p. 180-208, jan/abr. 2007 
CRAHAY, M.; BAYE, M. Existem escolas justas e eficazes? Esboço de resposta baseado no Pisa 2009. Cadernos de Pesquisa, v. 43, n.150 São Paulo Set./Dez. 2013.

CROZIER, M. A sociedade bloqueada. Brasília: Editora Universidade de Brasília, 1983.

CRUZ, R. E. Banco Mundial e política educacional: cooperação ou expansão dos interesses do capital internacional? Educar, n. 22, p. 51-75, 2003.

DUARTE, R. Entrevistas em pesquisas qualitativas. Educar em Revista, n. 24, p. 213-225, 2004.

DUBAR, C. Agente, ator, sujeito, autor: do semelhante ao mesmo. Primeiro Congresso da Associação Francesa de Sociologia, p. 56-69, fev. 2004. Disponível $\mathrm{em}$ http://uff.br/observatoriojovem/sites/default/files/documentos/dubarclaudeagenteatorsujeitoautor-atoragenteautordosemelhanteaomesmo2004.pdf. Acesso em 04/03/2017.

ELMORE, R. F. Diseño retrospectivo: la investigácion de la implementación y las decisiones políticas. In: VAN METER, D. S.; VAN HORN, C. E.; REIN, M.; RABINOVITZ, F. F. \& ELMORE, R. (dirs.). La implementación de las políticas. México: Miguel Angel Porru, 1996

ELLSTRÖM, P. Four Faces of Educational Organizations. Higher Education, n. 12, p. 231-241, 1983.

FERNANDES, D. C. Race, Socioeconomic Development and the Education Stratification Process in Brazil. Research in Social Stratification and Mobility, v. 22, p. 365-422, 2004.

FETZNER, A. Falas docentes sobre a não aprendizagem escolar nos ciclos. 2013. 167 f. Tese (Doutorado) Universidade Federal do Rio Grande do Sul, Programa de Pós-Graduação, Faculdade de Educação, Porto Alegre, RS, 2007.

FLETCHER, P. R.; COSTA RIBEIRO, S. Modeling Education System Performance with Demographic Data, An Introduction to the PROFLUXO Model, Paris: UNESCO, 1989.

FONSECA, C. Quando cada caso NÃO é um caso. Revista Brasileira de Educação, n.10, jan./fev./mar./abr. 1999

FREITAS L. C. de. Ciclos, seriação e avaliação: confronto de lógicas. São Paulo: Moderna, 2003

GADAMER, H. Verdade e método. Petrópolis: Vozes, 1999

GENTILI, P. Neoliberalismo e educação: manual do usuário. In: SILVA, T. T.; GENTILI, P. Escola S.A. - quem ganha e quem perde no mercado educacional do Neoliberalismo. Brasília: CNTE, 1996. p. 9-49

GRIS, P. C. Implementação do Programa Correção de Fluxo: repercussões no processo de escolarização de alunos participantes. 2015. 179 f. Dissertação (Mestrado em Educação). Universidade Comunitária da Região de Chapecó, Chapecó, 2015.

HABERMAS, J. Dialética e hermenêutica: para a crítica da hermenêutica de Gadamer. Porto Alegre: L\&PM, 1987 
HILL, H. C. Understanding Implementation: Street-level Bureaucrats' Resources for Reform. Journal of Public Administration Research and Theory, v. 13, n. 3, p. 265-282, 2003.

KARABEL, J.; HALSEY, A. H. Introduction: Educational Research: A Review and Interpretation. In: Power and Ideology in Education. New York: Oxford University Press, 1977. p. 1-85

KLEIN, R. Comentários sobre Teixeira de Freitas e seus trabalhos na área da educação. In: Instituto Brasileiro de Geografia e Estatística - IBGE, Teixeira de Freitas, um Cardeal da educação brasileira: sua atualidade intelectual. Rio de Janeiro, 2008, p. 15-25. Disponível em: http://biblioteca.ibge.gov.br/d_detalhes.php?id=240800.

KNOBLAUCH, A. Ciclos de aprendizagem e avaliação de alunos: novas práticas de registro, velhas intenções. XX Reunião Anual da ANPED, Caxambu, 2003

LALLI, V. S. O Programa Acelera Brasil. Em Aberto. Brasília, v. 17, n. 71, p. 57-73, jan. de 2000

LEITHWOOD, K.; SUN, J. Transformational school leadership effects on schools, teachers and students. In: HOY, W. K. e DIPAOLA, M. (Eds.), School improvement. New York: Information Age, p. 1-22, 2009

LENSKI, G. Power and Privilege. New York: McGraw-Hill, 1966

LEWIN, K. Principles of Topological Psychology. New York: McGraw-Hill, 1936.

LIMA, L. A escola como organização educativa. $4^{a}$ ed. São Paulo: Cortez, 2011.

LIMA, L; D'ASCENZI, L. Implementação de políticas públicas: perspectivas analíticas. Revista de Sociologia e Política. v. 21, n. 48, p. 101-110, dez. 2013

LIMA, M. de F. M. Correção de Fluxo na Rede Pública Municipal do Rio de Janeiro (2009-2014): aspectos da política e as trajetórias dos alunos. 2016. 226 f. Tese (Doutorado em Educação) - Departamento de Educação, Pontifícia Universidade Católica do Rio de Janeiro, Rio de Janeiro, 2016.

LIPSKY, M. Street-level bureaucracy: dilemmas of the individual in public service. New York: Russel Sage Foundation, 1980.

LOTTA, G. S. Implementação de políticas públicas: o impacto dos fatores relacionais e organizacionais sobre a atuação dos Burocratas de Nível de Rua no Programa Saúde da Família. 2010. 295 f. Tese (Doutorado em Ciência Política) - Faculdade de Filosofia, Letras e Ciências Humanas, Universidade de São Paulo, São Paulo, 2010.

LOTTA, G. S. Agentes de implementação: uma forma de análise de políticas públicas. Cadernos Gestão Pública e Cidadania. São Paulo, v.19, n.65, jul./dez. 2014

MAINARDES, J. Organização da escolaridade em ciclos no Brasil: revisão da literatura e perspectivas para a pesquisa. Educação e Pesquisa. São Paulo, v. 32, n. 1, p. 11-30, jan./abr. 2006

Reinterpretando os ciclos de aprendizagem. São Paulo: 
MAJONE, G.; QUADE, E.S. (eds.) Pitfalls of Analysis. London: John Wiley and Sons, 1980.

MARE, R. Social background and the school continuation decision. Journal of American Statistical Association, v. 75, n. 370, p. 295-305, 1980.

Change and stability in educational stratification. American Sociological Review, v. 46, n. 3, p.72-87, 1981.

MARKS, H. M.; PRINTY, S. M. Principal leadership and school performance: An integration of transformational and instructional leadership. Educational Administration Quarterly, v. 39, n. 3, p. 370-397, ago. 2003.

MAYNARD-MOODY, S.; MUSHENO, M. Cops, Teachers and Counselors: Stories from the Front Lines of Public Service. Ann Arbor: The University of Michigan Press, 2003.

MAZMANIAN, D. A.; SABATIER, P. A. Implementation and Public Policy. Glenview: Scott Foresman, 1983

MEIER, K. J.; O'TOOLE, L. J. Bureaucracy in a democratic state: a governance perspective. Baltimore: The Johns Hopkins University Press, 2006

MINAYO, M. C. S. O desafio do conhecimento. Pesquisa Qualitativa em Saúde. 10ª ed. São Paulo: Hucitec, 2010.

NEVES, C. E. B. Estudos sociológicos sobre educação no Brasil. In: MICELI, Sergio (Org.). O que ler na ciência social brasileira. São Paulo/Brasília: ANPOCS/Sumaré, 2002. p. 351-437

NUNES, C. O "velho" e "bom" ensino secundário: momentos decisivos. Revista Brasileira de Educação, n. 14, p.35-60, 2000.

OLIVEIRA, A. Burocratas da linha de frente: executores e fazedores das políticas públicas. Rev. Adm. Pública, v. 46, n. 6, p. 1551-1573, nov./dez. 2012

OLIVEIRA, A. C. P. As relações entre Direção, Liderança e Clima Escolar em escolas municipais do Rio de Janeiro. 284 f. Tese (Doutorado em Educação). Pontifícia Universidade Católica do Rio de Janeiro, Programa de Pós-Graduação em Educação, Rio de Janeiro, 2015.

OLIVEIRA, R. P; ARAUJO, G. C. Qualidade do ensino: uma nova dimensão da luta pelo direito à educação. Revista Brasileira de Educação, n. 28, jan./fev./mar./abr. 2005

OLIVEIRA, R. P. Da universalização do ensino fundamental ao desafio da qualidade: uma análise histórica. Educação e Sociedade, v. 28, n. 100, p. 661690, out. 2007

ORTIGÃO, M. I; AGUIAR, G. S. Repetência escolar nos anos iniciais do ensino fundamental: evidências a partir dos dados da Prova Brasil 2009, Rev. bras. Estud. Pedagógicos. Brasília, v. 94, n. 237, p. 364-389, maio/ago. 2013.

PAES DE CARVALHO, C.; OLIVEIRA, A. C. P.; LIMA, M. F. M. Avaliações externas: tensões e desafios para a gestão escolar. Est. Aval. Educ., São Paulo, v. 25, n. 59, p. 50-77, set./dez. 2014. 
PARENTE, M. M. A; LÜCK, H. Mecanismos e experiências de correção do fluxo escolar no ensino fundamental. Brasília: IPEA, julho de 2004 (Texto para discussão 1032).

Aceleração da Aprendizagem para corrigir o

fluxo escolar: o caso do Paraná. Brasília: IPEA, julho de 2007 (Texto para discussão 1274)

PARSONS, T. The school class as a social system: some of its functions in American society. Harvard Educational Review, n. 29, p. 287-318, 1959

Equality and inequality in modern society, or social stratification revised. In: LAUMANN, E. (Ed.). Social Stratification: Research and Theory for the 1970s. Indianapolis: Bobbs-Merrill, 1970.

O sistema das sociedades modernas. São Paulo: Pioneira, 1974.

PATTO, M. H. S. A produção do fracasso escolar: histórias de submissão e rebeldia. São Paulo: T. A. Queiroz, 1996

PEREIRA, L. A escola numa área metropolitana. São Paulo, Pioneira, 1967.

PINTO, R. A educação do negro: uma revisão da bibliografia. Cadernos de Pesquisa, n. 62, p. 3-34, 1987.

PLACCO, V. M. N. S; ANDRÉ, M. E. D. A.; ALMEIDA, L. R. Estudo avaliativo nas classes de aceleração na rede estadual paulista. Cadernos de Pesquisa, n. 108, p. 49-79, nov.1999

PRADO, I. G. A. LDB e Políticas de Correção de Fluxo Escolar. Em Aberto, Brasília, v. 17, n. 71, p. 49-56, jan. 2000.

PRESSMAN, J.; WILDAVSKY, A. Implementation. $3^{\text {rd }}$ ed. Berkeley: University of California Press, 1984

RIBEIRO, C. A. C. Desigualdade de oportunidades e resultados educacionais no Brasil. Dados. v.54, n.1, p. 41-87, 2011

RIO DE JANEIRO. Portaria E/DGED no 14, de janeiro de 2001. Dispõe sobre a organização de turmas e cria as Classes de Progressão.

Secretaria Municipal de Educação. Conselho Municipal de Educação. Câmara de Políticas Sociais Integradas à Educação. Indicação N. ${ }^{\circ}$ 3/2007. Apresenta considerações sobre o pensar pedagógico norteador dos ciclos de formação do Ensino Fundamental da Cidade do Rio de Janeiro, 29/05/2007. In: Diário Oficial do Rio. Rio de Janeiro, Ano 20, n.59, 14 jun. 2007a, p.23-26.

Resolução no 946 de abril 2007 da SME. Estabelece diretrizes para a avaliação escolar na rede pública do sistema municipal de ensino da cidade do rio de janeiro e dá outras providências. 2007b.

Decreto $\mathbf{n}^{\mathbf{0}}$ 28.878, de 14 de dezembro de 2007. Estabelece diretrizes para a avaliação escolar na Rede Pública do Sistema Municipal de Ensino da Cidade do Rio de Janeiro e dá outras providências. 2007c.

Decreto $\mathbf{n}^{\circ}$ 30.340, de 01 de janeiro de 2009a. Revoga o Decreto 28.878, de 17/12/2007, que cuida da "aprovação automática" no âmbito da Rede Pública de Ensino Municipal e dá outras providências. Disponível em: <http://smaonline.rio.rj.gov.br/conlegis/>. Acesso em: 04/03/2017. 
Plano Estratégico da Prefeitura da Cidade do Rio de

Janeiro 2009-2012. Disponível em:

http://www.riocomovamos.org.br/arq/planejamento_estrategico.pdf. Acesso em: 04/03/2017. 2009b.

Acordo de Resultados. Ver em: http://www.rio.rj.gov.br/dlstatic/10112/2116763/4104311/acordoderesultadosbx.p df. Acesso em 04/03/2017. 2009c.

Lei 5215 de 02/10/10. Dispõe sobre a revisão do Plano Plurianual 2010-2013 para o período 2010-2013. Publicado no Diário Oficial de 23/08/2010. Suplemento. 2010a

Resolução SME 1079 de 27 de maio de 2010. Instituiu projetos especiais de correção de fluxo na Rede Pública Municipal de Ensino do Rio de Janeiro e dá outras providências. Publicado no Diário oficial de 28/05/2010b.

ROSENTHAL, R. A; JACOBSON, L. Pgymalion in the Classroom: Teacher expectations and pupil's intellectual development. New York: Holt, Rinehart, and Winston, 1968.

RUTTER, M.; MAUGHAN, B.; MORTIMORE, P.; OUSTON, J.; SMITH, A. Fifteen Thousand hours: Secondary Schools and their Effects on Children. London: Open Books, 1979

SÁ EARP, M. de L. A cultura da repetência em escolas cariocas. Ensaio: aval. pol. Públ. Educ. Rio de Janeiro, v. 17, n. 65, p. 613-632, out./dez. 2009

SABATIER, P.; MAZMANIAN, D. The Conditions of Effective Implementation. Policy Analysis, v. 5, p. 481-504, 1979

SAMMONS, P. As características-chave das escolas eficazes. In: BROOKE, N.; SOARES, J. F. (Org.). Pesquisa em eficácia escolar: origem e trajetórias. Belo Horizonte: Editora UFMG, 2008.

SAMPAIO, M. M. F. Aceleração de Estudos: uma intervenção pedagógica. Em Aberto, Brasília, v.17, n.71, p.57-73, jan. 2000.

SANTOS, J.C. O Gerencialismo no novo modelo de educação pública da Cidade do Rio de Janeiro (2009-2012): origens, implantação, resultados e percepções. $208 \mathrm{f}$. Tese (Doutorado em Educação). Universidade Federal do Rio de Janeiro, Faculdade de Educação, Programa de Pós-Graduação em Educação, Rio de Janeiro, 2014.

SCHLEIERMARCHER, F. Hermenêutica: arte e técnica da interpretação. Petrópolis: Vozes, 2000

SCHWARTZMAN, S; BOMENY, H. M. B.; COSTA, W. M. R. A Reforma da Educação. In: (Orgs.) Tempos de Capanema. São Paulo: Paz e Terra: Fundação Getúlio Vargas, 2000, p.189-219

SHAVIT, Y.; BLOSSFELD, H. Persistent inequality: A comparative study of educational attainment in thirteen countries. Boulder, CO: Westview Press, 1993. 
SILVA, N. do V. Expansão Escolar e Estratificação Educacional no Brasil. In: SILVA, N. do V. e HASENBALG, C. (eds.). Origens e Destinos: Desigualdades Sociais ao Longo da Vida. Rio de Janeiro, Topbooks, 2003, p. 105-138

SILVA, P. L. B.; MELO, M. A. B. 2000. O processo de implementação de políticas públicas no Brasil: características e determinantes da avaliação de programas e projetos. Caderno NEPP/UNICAMP, Campinas, n. 48, p. 1-16. Disponível em: http://governancaegestao.files.wordpress.com/2008/05/teresaaula_22.pdf. Acessado em 04/03/2017

SOARES, M. Linguagem e escola: uma perspectiva social. $17^{\text {a }}$ ed. São Paulo: Ática, 2014.

SOUZA, C. Políticas Públicas: uma revisão da literatura. Sociologias, Porto Alegre, ano 8, n. 16, p. 20-45, jul./dez. 2006.

SOUZA, C. M. O Projeto Realfabetização no Município do Rio de Janeiro: a participação dos docentes da $\mathbf{7}^{\mathbf{a}}$ Coordenadoria Regional de Educação. 2012, 232 f. Mestrado Acadêmico em Educação, Universidade Federal Fluminense, Niterói, Rio de Janeiro, 2012

STEIN, E. Dialética e hermenêutica: uma controvérsia sobre método em filosofia. In: HABERMAS, J. Dialética e hermenêutica: para a crítica da hermenêutica de Gadamer. Porto Alegre: L\&PM, 1987. p. 98-134.

TREIMAN, D. Industrialization and social stratification. In: LAUMANN, E. (Ed.). Social Stratification: Research and Theory for the 1970s. Indianapolis: Bobbs-Merrill, 1970.

TRONCIN, T. Le Redoulement: radiographie d'une décision à la recherce de sa légitimité. Djon, 2005. Thèse (doct.) Université de Dijon.

TUMMERS, L.; BEKKERS, V. Policy implementation, street-level bureaucracy, and the importance of discretion. Public Management Review, v. 16, n. 4, p. 527-547, 2014

TURA, M. L. R.; MARCONDES, M. I. O mito do fracasso escolar e o fracasso da promoção automática. Cadernos de Educação, FaE/PPGE/UFPel, Pelotas, n. 38, p. 95 - 118, jan./abr. 2011. 


\section{9 \\ Apêndices}

\section{Apêndice 1.}

Roteiro para Entrevista Semiestruturada: Diretor(a)

\section{Características sociodemográficas}

\begin{tabular}{|l|l|}
\hline Sexo & \\
\hline Idade; Mês/Ano de nascimento & \\
\hline Formação acadêmica: Curso Superior / IES & \\
\hline Pós-Graduação (tipo e área): & \\
\hline Número de anos trabalhando nesta escola & \\
\hline Experiência profissional fora do campo educacional & \\
\hline $\begin{array}{l}\text { Trabalhou em outras escolas? Quantas e de que tipo (pública ou } \\
\text { privada)? }\end{array}$ & \\
\hline $\begin{array}{l}\text { Está trabalhando atualmente em outras escolas? Quantas e de que } \\
\text { tipo (pública ou privada)? }\end{array}$ & \\
\hline
\end{tabular}

\section{Sobre a escola}

- O que mais caracteriza a escola;

- Missão e valores da escola;

- Perfil dos alunos atendidos

- Distorção idade série;

- Relação com o ambiente externo / entorno da escola (pais, comunidade, etc)

- Como influencia ou apoia o trabalho dos professores para aprendizagem dos alunos (regulares e de projetos);

- Grau de dificuldade para conseguir professores para os projetos;

- Crenças / previsões sobre o estado da escola daqui a 5 / 10 anos, metas a serem alcançadas;

- Principais dificuldades ou desafios para alcançar essas metas / para fortalecer uma cultura de aprendizagem; 


\section{Sobre os projetos e os alunos}

- Chegada dos projetos à escola (comunicação, capacitação dos agentes, material)

e mudanças desde sua entrada;

- Critério de encaminhamento dos alunos para os projetos

- Critério para a seleção de professores para o trabalho com os projetos

- Percepção sobre os alunos (frequência, dedicação, resultados etc)

- Percepção sobre os projetos 


\section{Apêndice 2.}

Roteiro para Entrevista Semiestruturada: Professores e Agentes Educadores

\section{Características sociodemográficas}

\begin{tabular}{|l|l|}
\hline Sexo & \\
\hline Idade; Mês/Ano de nascimento & \\
\hline Formação acadêmica: Curso Superior / IES & \\
\hline Pós-Graduação (tipo e área): & \\
\hline Número de anos trabalhando nesta escola & \\
\hline Experiência profissional fora do campo educacional & \\
\hline $\begin{array}{l}\text { Trabalhou em outras escolas? Quantas e de que tipo (pública ou } \\
\text { privada)? }\end{array}$ & \\
\hline $\begin{array}{l}\text { Está trabalhando atualmente em outras escolas? Quantas e de que } \\
\text { tipo (pública ou privada)? }\end{array}$ & \\
\hline
\end{tabular}

\section{Sobre a escola}

- O que mais caracteriza a escola;

- Perfil dos alunos atendidos (residências, comunidades próximas);

- Distorção idade série;

- Missão da escola;

\section{Sobre o projeto e os alunos}

- Chegada do projeto à escola (comunicação, capacitação dos agentes, material) e mudanças desde sua entrada

- Critério de encaminhamento dos alunos para os projetos

- Critério para a seleção de professores para o trabalho com os projetos

- Diferenças/semelhanças entre os alunos inseridos em turmas regulares e em turmas de projeto;

- Percepção sobre o trabalho com os projetos

- Percepção sobre a atuação multidisciplinar e sobre o material padronizado

- Momentos de planejamento e discussão

- Apoio recebido por parte da equipe gestora e dos outros professores

- Percepção sobre os alunos (frequência, dedicação, resultados etc) 


\section{Apêndice 3.}

Roteiro para Entrevista Semiestruturada: Alunos(as)

\section{Trajetória pessoal}

- Idade, série, escolas anteriores, onde mora/família, escolha da escola

- Tempo na escola, como/por que foi estudar lá;

- Experiência com professores especialistas;

- Repetências anteriores (por que repetiu, o que aconteceu);

\section{Sobre a escola}

- O que mais caracteriza a escola (aspectos positivos e negativos);

- Expectativas de vida (onde se vê daqui a 5 / 10 anos);

- Importância da escola no alcance dessas expectativas;

\section{Projeto}

- Critério de encaminhamento dos alunos para os projetos;

- Recepção do projeto (por parte do aluno e de sua família);

- Percepção sobre a polivalência dos professores e sobre o material padronizado;

- Relacionamento com os professores e com a gestão

- Relacionamento com demais alunos;

- Participação e frequência;

- Percepção sobre o projeto (aspectos positivos e negativos); 